\title{
ABORDANDO AS RELAÇÕES AGRICULTURA E MEIO AMBIENTE NO ENSINO FORMAL, ATRAVÉS DA EDUCAÇÃO AMBIENTAL - CONSIDERAÇÕES A PARTIR DE UM CASO
}

\author{
ANTONIO VITOR ROSA \\ Geógrafo
}

Orientador: Prof. Dr. MARcos SORRENTINO

Dissertação apresentada à Escola Superior de Agricultura " Luiz de Queiroz", Universidade de São Paulo, para obtenção do título de Mestre em Ciências, Área de Concentração: Ciências Florestais.

\author{
PIRACICABA \\ Estado de São Paulo - Brasil \\ Agosto - 2001
}




\title{
Dados Internacionais de Catalogação na Publicação (CIP) DIVISĀO DE BIBLIOTECA E DOCUMENTAÇÃO - Campus "Luiz de Queiroz"/USP
}

\author{
Rosa, Antonio Vitor \\ Abordando as relaçōes agricultura e meio ambiente no ensino formal, através da \\ educação ambiental : consideraçōes a partir de um caso / Antonio Vitor Rosa. - - \\ Piracicaba, 2001. \\ $260 \mathrm{p}$. \\ Dissertação (mestrado) - - Escola Superior de Agricultura Luiz de Queiroz, 2001. \\ Bibliografia. \\ 1. Educação ambiental 2. Ensino médio 3. Formação de professor 4. Relação \\ agricultura-meio ambiente I. Título \\ CDD 333.707
}

"Permitida a cópia total ou parcial deste documento, desde que citada a fonte - $\mathrm{O}$ autor" 


\section{AGRADECIMENTOS}

à FAPESP pela financimanta desta pesquisa (Pracessa 98/12381-7) .

Aa meu pai Dulcídio, à minha mãe Belita e aa Adri que sempre apaiaram-me e sauberam respeitar a meu espaça damiciliar de estuda/trabalha.

à Flávia pela carinha, campanhia, campreensãa e apaia nestes três anas.

à Edilene e aa Dauglás pelas apaias operacianais na praduçãa da dissentaçãa.

Aa Edu è à Marcia pela amizade e pelas energias pasitivas irradiadas.

à Míriam pelas primeiras cantatas em Piracicata e pelas peixes e canuersas na Rua da Parta.

à Juane pela ajuda cam a inglês.

à Simone, aa Pedra, aa Fábia e aa Gabriel pelas acaltidas em sua casa.

Aa pessoal da LEPa, em especial a Sandra, Marca e Mauricia pelas apaias, debates e crescimenta campartilhada.

Aas calegas de estuda e reflexãa: Cristina D., Eristina V., Denise, Jlza, Maurícia, Mânica e Ricarda.

Aa professar Natal pela atençãa e pela apaia nas questães administratiuas.

As prafessoras e prafessares Eda, Ondalua, Laurdes, Caran, e Brandãa pelas awaliaçães e camentárias sabre a trabalha.

Cas educadares e especialistas: Geralda Magela, Ondalua, Petter, Fernanda, Geralda Franca, Ângela, Maxitia, Jussara e Jsabet pelas importantes cantribuiçães na trabalha de campa.

$\grave{a}$ Diretaria de Ensina de Sãa Raque, em especial à $a \mathcal{S P}$ Aparecida, as diretares e funcianárias das escalas pela abertura e suparte à pesquisa.

Aa Marcas pela atençãa, carinha, dedicaçãa, respeita, campramissa cam a pesquisa e cam a meu pracessa de aprendizagem.

Par firm e de farma muita especial agradega as educadares Ângela, Darathéa, Fátima, Jaana, Luciana, Matir, Maureen, Maria Jasé, Neuza, Narma, Odete, Tëdra, Rita, Sara, Vera, Barka, Deimar, Hélia, Paula, Regis, Sáwia e Valdemir pela abertura, compramissa, dedicaçãa, alegria e caragem, _- cam as quais eles se envalueram na propasta. 


\section{DEDICATÓRIA}

Dedica este trabalha à professara Odete Saita Machada e aas muitas educadares que, a despeita das dificuldades, acreditam e dedicam-se em pral da educaçãa pública e de qualidade, cama um meia de canstruçãa de uma cultura de qualidade de vida e de sustentabilidade sácia-ambiental. 


\section{SUMÁRIO}

Página

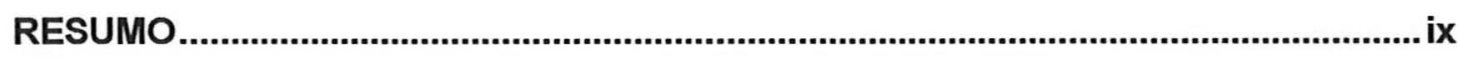

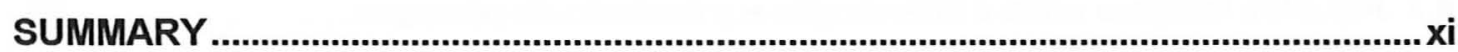

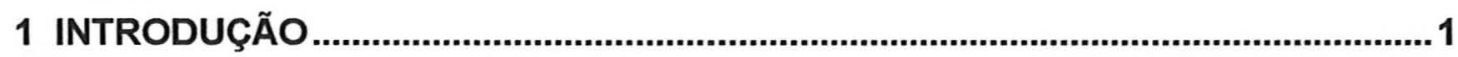

1.1 Apresentação da pesquisa e da dissertação ........................................................ 1

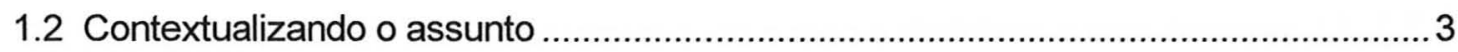

1.3 Objetivos

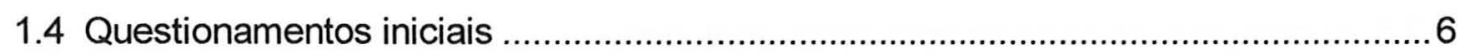

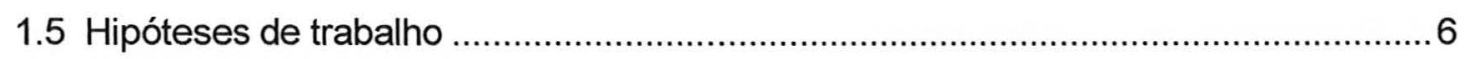

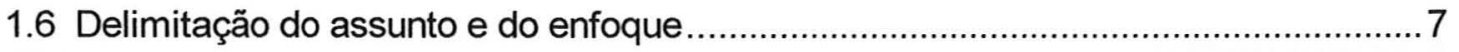

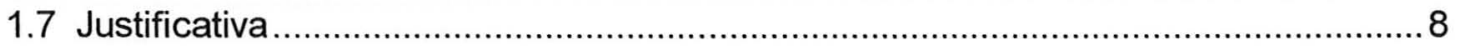

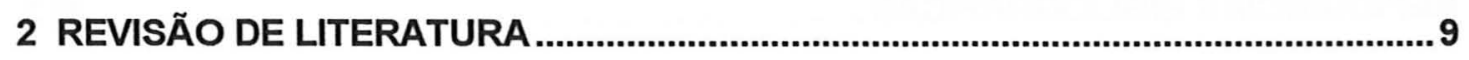

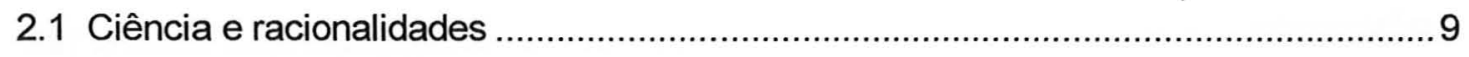

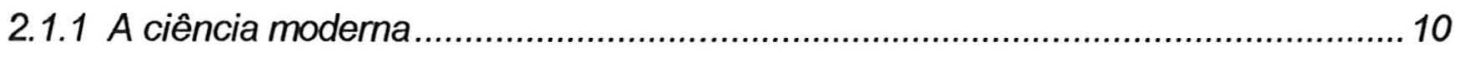

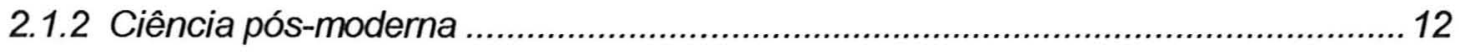

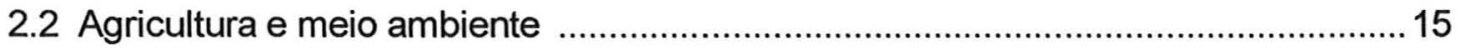

2.3 Ambientalismo e educação ambiental (uma interpretação) ................................... 18

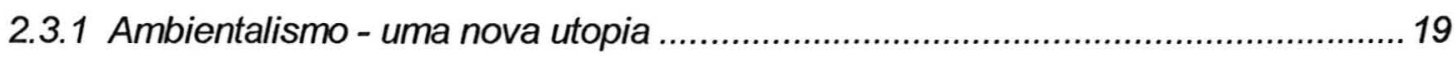

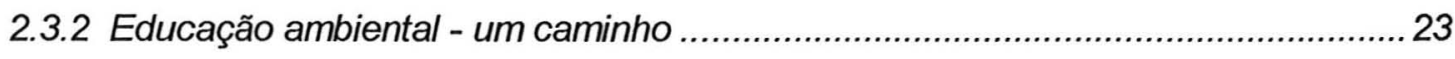

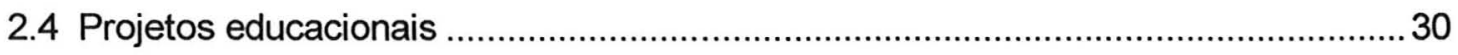


3 METODOLOGIA

3.1 Pesquisa em educação e a multirreferencialidade ................................................... 35

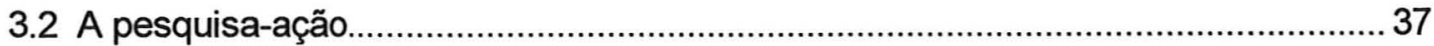

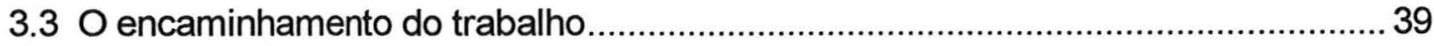

3.4 A intervenção educacional - um recurso de pesquisa ............................................. 44

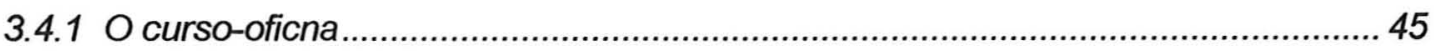

3.5 Mapeamento de aspectos significativos para pesquisa ......................................... 50

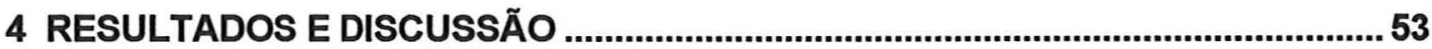

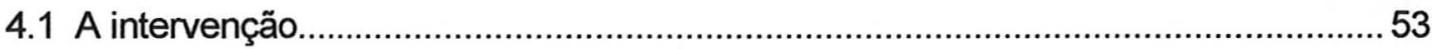

4.2 Algumas relações entre a intervenção e o contexto de pesquisa .............................. 55

4.3 Discutindo os aspectos significativos da pesquisa................................................. 56

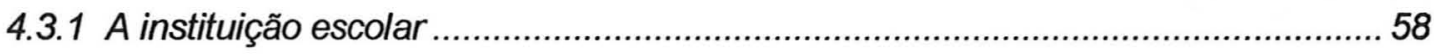

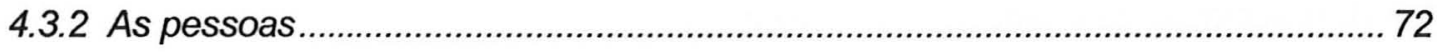

4.3.3 As relações com a realidade e com o conhecimento.......................................... 77

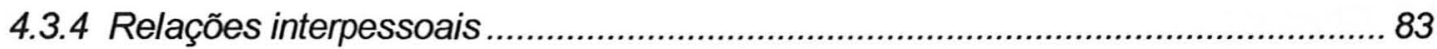

4.3.5 Abordagem educacional agro-sócio-ecológica ................................................. 88

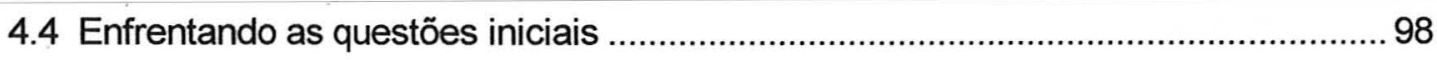

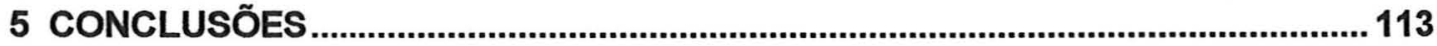

REFERÊNCIAS BIBLIOGRÁFICAS .................................................................... 117

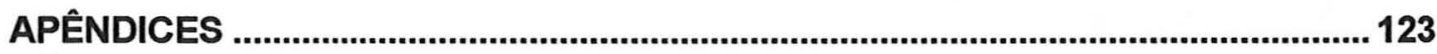




\title{
ABORDANDO AS RELAÇÕES AGRICULTURA E MEIO AMBIENTE NO ENSINO FORMAL, ATRAVÉS DA EDUCAÇÃO AMBIENTAL - CONSIDERAÇÕES A PARTIR DE UM CASO.
}

\author{
Autor: ANTONIO VITOR ROSA \\ Orientador: Prof. Dr. MARCOS SORRENTINO
}

\section{RESUMO}

A pesquisa visa ampliar os conhecimentos sobre abordagens no ensino escolar que tratam as relações entre agricultura e meio ambiente e que procuram potencializar os educandos no questionamento do modelo agrícola convencional e na valorização de produtos e iniciativas agrícolas alternativas. Buscou-se um tratamento exploratório sobre o assunto, tendo como referência três questões: a) Como é tratado no ensino médio as relações agro-ambientais? b) Como ampliar e melhorar este tratamento? c) Que conseqüências pode ter esta ampliação? O trabalho delineado como uma pesquisa qualitativa, baseou a parte de campo na proposta da pesquisa-ação. $O$ procedimento principal para gerar dados e subsidiar a interpretação do objeto-processo de estudo foi promover e monitorar uma intervenção educacional junto a educadores da rede pública de ensino. A idéia de multirreferencialidade em estudos educacionais influenciou o tratamento do extenso conjunto de dados gerados. Os resultados do estudo evidenciaram que: 1) Os conhecimentos dos educadores sobre as relações agro-ambientais são, em geral, muito pequenos e pontuais, implicando em um tratamento superficial do assunto. 2) $\mathrm{Na}$ abordagem educacional das relações agro-ambientais mostraram-se altamente adequados procedimentos envolvendo: a) processos não pontuais de aperfeiçoamento de educadores sobre o tema; b) promoção de projetos educacionais em equipes multidisciplinares; c) 
realização de diagnósticos agro-sócio-ambientais locais; d) a promoção de outras relações dos educandos com o conhecimento e com a realidade o que inclui desmistificar a ciência, exercitar novos olhares e novas compreensões e estimular a relação direta do educando com o assunto estudado destacando-se: visitas à estabelecimentos agrícolas com produção alternativa e a manipulação de elementos naturais (plantas e terra) em atividades escolares com horta orgânica e com mudas de árvores. 3) A pesquisa-ação constitui-se uma eficiente estratégia em pesquisas educacionais. 4) Há sérios problemas no sistema de ensino escolar incluindo falta de condições de trabalho e deficiência na formação e aperfeiçoamento dos educadores. 5) Tanto o tratamento do tema pode aproximar os educandos das questões ambientais em geral, como o tratamento de outras questões ambientais pode aumentar as preocupações agro-ambientais dos educandos. 6) Ocorrem limitações extra-educacionais especificas e maiores que as enfrentadas no tratamento de outros temas ambientais. O que remete à necessidade de políticas públicas regionais que incluam e articulem a divulgação e formação sobre as relações agro-ambientais com o apoio à produção, escoamento e consumo de produções agrícolas alternativas. 7) Com apoio de universidades, instituições de pesquisa ou extensão, secretarias e outros órgãos governamentais, é grande a possibilidade das escolas transformarem-se em espaços qualificados de difusão sobre as relações agro-ambientais. 


\title{
APPROACHING THE AGRICULTURE AND ENVIRONMENT RELATIONS IN THE FORMAL TEACHING, THROUGH THE ENVIRONMENTAL EDUCATION - CONSIDERATIONS STARTING FROM A CASE.
}

\author{
Author: ANTONIO VITOR ROSA \\ Adviser: Prof. Dr. MARCOS SORRENTINO
}

\section{SUMMARY}

The research seeks to extend the knowledge on approaches in the school teaching that they treat the relationships between agriculture and environment and those they try to fortify the students in the question of the conventional agricultural model and in the valorization of products and alternative agricultural initiatives. An exploratory treatment was looked for on the subject, tends as reference three subjects: a) How it is treated in the medium teaching the agriculture-environmental relationships? b) How to enlarge and to improve this treatment? c) What consequences can have this enlargement? The work delineated as a qualitative research, it based the field part on the proposal of the researchaction. The main procedure to generate data and to subsidize the interpretation of the study object-process was to promote and to monitor an education intervention close to educators of the public net of teaching. The multirreferencety idea in education studies influenced the treatment of the extensive group of generated data. The results of the study evidenced that: 1) the educators' knowledge about the agriculture-environmental relationships are, in general, very small and punctual, implicating in a superficial treatment of the subject. 2) In the education approach of the agriculture-environmental relationships highly appropriate procedures were shown involving processes don't punctuate of educators' improvement on 
the theme; promotion of education projects in teams multidisciplinary; accomplishment of local agriculture-partner-environmental diagnoses and the promotion of the students' other relationships with the knowledge and with the reality that includes to demystify the science, to exercise new glances and new understandings and to stimulate the student's direct relationship with the studied subject standing out: visits to agricultural establishments with alternative production and the manipulation of natural elements (plants and earth) in school activities with organic vegetable garden and with seedlings of trees. 3) The research-action an efficient strategy is constituted in education researches. 4) There are serious problems in the school education system including lack of work conditions and deficiency in the formation and the educators' improvement. 5) So much the treatment of the theme can approximate the students of the environmental subjects in general, as the treatment of other environmental subjects it can increase the students' agriculture-environmental concerns. 6) They happen specific and larger extra-education limitations than faced them in the treatment of other environmental themes. It sends to the need of regional public politics that include and articulate the popularization and the formation about the agriculture-environmental relationships with the support to the production, drainage and consumption of alternative agricultural productions. 7) With support of universities, research institutions or extension, general offices and other government organs, it is big the possibility of the schools be transformed in qualified spaces of diffusion about the agriculture-environmental relationships. 


\section{INTRODUÇÃO}

\subsection{APRESENTAÇÃO DA PESQUISA E DA DISSERTAÇÃO}

Considerando o pequeno acúmulo teórico, a complexidade e a necessidade de formulação de uma visão panorâmica inicial sobre o assunto pesquisado, optei pela realização de um estudo científico de caráter exploratório que buscou identificar os principais aspectos e relações do objeto-processo de estudo.

O trabalho e principalmente o texto representam um ponto de vista, para o qual foi buscado o máximo de embasamento científico. É preciso atentar que este "ponto de vista" foi formulado sob influência do orientador, de muitos que, pessoalmente ou através de suas obras, colaboraram no trabalho e principalmente pelos educadores que foram envolvidos na pesquisa de campo.

Os múltiplos aspectos emergentes na pesquisa não receberam os aprofundamentos que seriam possíveis se cada um fosse abordado pelo correspondente especialista (pedagogo, psicólogo, sociólogo, agrônomo, etc.) elou se um determinado aspecto fosse escolhido para detalhamento. Mas considero que o estudo terá seu valor se conseguir oferecer uma avaliação mais global sobre o assunto, constituindo-se em suporte ou provocação para outros estudos.

O que me motivou foi contribuir para a produção e sistematização de conhecimentos os mais adequados e precisos possíveis, de forma a avançar no sentido do meu objetivo mais geral, conforme declarado no item objetivos. Creio que este objetivo geral exerceu um importante papel no policiamento e cobrança da qualidade do trabalho científico. Estas considerações sobre o trabalho são necessárias visto que se adotou uma metodologia não alinhada com o paradigma científico dominante nas áreas biológica e física; além disso, em grande parte a pesquisa procura avaliar interpretações, propostas, procedimentos e outros aspectos envolvendo o próprio pesquisador, o que poderá remeter a superados questionamentos vinculando qualidade científica e isenção do pesquisador. 
Iniciamos o trabalho baseando-nos na perspectiva da pesquisa-ação, por conta disso um dos principais procedimentos do estudo foi a promoção e monitoramento de numa intervenção educacional para e com um grupo de educadores.

Considerando a emergência de um rico conjunto de dados passamos a adotar o conceito de complexidade e a proposta de multirreferencialidade em estudos educacionais. O trabalho foi se delineando como uma pesquisa qualitativa com fortes convergências a denominada "teoria crítica".

No transcorrer do trabalho de campo identifiquei ou confirmei graves problemas relacionados à estrutura e às políticas governamentais para o sistema educacional o que, em dado momento, levou-me a questionar a relevância do trabalho diante de dificuldades e problemas tão amplos e emergenciais. Porém, o reforço da importância da iniciativa deu-se por considerações do tipo: i) a pesquisa pode oferecer uma pequena contribuição para as necessárias mudanças estruturais no Sistema de Ensino; ii) O quadro apresenta pequenas conquistas e brechas que precisam ser ocupadas; iii) Um grande número de educadores da rede público apresenta uma enorme persistência em seus ideais de qualidade de ensino aliado a uma maleabilidade e a um poder de renovação diante das dificuldades, sendo que a pesquisa poderá reforçar tais potencialidades.

Por conta da boa avaliação do curso e da riqueza dos dados procurei descreve-lo com relativo grau de detalhes, em um memorial que juntamente com uma série de "instrumentos" de coleta de dados e "produtos" gerados no curso encontram-se nos Apêndices, os quais são partes importantes da dissertação considerando que eles:

a) apresentam uma descrição de uma iniciativa envolvendo objeto-processo de estudo;

b) compõem uma coleção de "dados brutos" que colaboram para a avaliação da confiabilidade da pesquisa;

c) são fontes de consulta para outras pesquisas ou cursos.

Por fim, se há valores neste trabalho eles são devidos principalmente ao orientador, aos educadores envolvidos na pesquisa e a vários outros colaboradores, porém considerei inadequado na dissertação usar a $3^{a}$ pessoa do plural, pois implicaria dividir a responsabilidade dos erros, que são meus, com outros atores. Também considerei que sendo eu parte importante do "objeto-processo" da pesquisa não seria interessante usar a $1^{a}$ pessoa. Assim procurei apresentar o texto como se fosse um narrador. 


\subsection{Contextualizando o assunto}

As relações entre agricultura e meio ambiente e seus desdobramentos são importantes para a sociedade brasileira, em função de aspectos como:

a) a grande extensão territorial ocupada pelas atividades agrícolas;

b) a relevância dos impactos ambientais causados pela agricultura;

c) as interferências que exercem sobre a alimentação e sobre a saúde pública e

d) o potencial sócio-econômico oferecido por áreas rurais que possuem qualidades ambientais propícias ao lazer, turismo, terapias físico e mental alternativas, esportes e outros serviços.

O modelo de agricultura moderna implantada em muitas partes do mundo, principalmente após a $2^{\mathrm{a}}$ Guerra Mundial, aumentou a produtividade por área e também facilitou a ocupação de novas áreas para cultivo, proporcionando um grande aumento da produção agrícola geral. Simultaneamente a sua adoção, na maioria dos lugares, surgiu uma série de problemas agrícolas, ambientais, sociais, econômicos, sanitários e outros. Por outro lado verifica-se diversas propostas e iniciativas agrícolas alternativas, inclusive, algumas destas buscam constituir agrossistemas ambientalmente sustentáveis.

Porém atualmente o assunto é tratado quase exclusivamente por uns poucos especialistas na área agrícola, ocupados com uma demanda mais pragmática e imediata, suas atuações têm alcance limitado, atingindo apenas uma pequena parcela de um segmento da sociedade (alguns produtores rurais). Apesar de sua importância o assunto é pouco conhecido pela sociedade. Em geral a população urbana desconhece os impactos e os problemas ambientais relacionados à agricultura. Já os segmentos sociais diretamente ligados às atividades agricolas enfrentam uma grande pressão econômica, social e cultural no sentido da adoção de práticas agrícolas que, em geral, a médio e longo prazo são extremamente danosas ao meio ambiente e a qualidade de vida de produtores e consumidores agrícolas.

O grande desconhecimento da população sobre tais alternativas é provavelmente um dos fatores que retarda a difusão das propostas alternativas entre os produtores e impede que os consumidores valorizem tais propostas. Considerando este quadro, alguns autores destacam a necessidade de se ampliar a denúncia dos problemas da agricultura 
moderna e de se conscientizar sobre a importância da busca de alternativas agricolas. Esta intenção pode ser observada em Almeida quando afirma que "a ampliação da crítica ao modelo agrícola dominante para o conjunto da sociedade e, sobretudo, a tradução dessa crítica em termos de sustentação social e política a uma proposta alternativa constituem algumas das tarefas centrais na construção de uma nova agricultura" (1991, p.3). Já o Relatório das ONGs. brasileiras para a ECO/92, sustenta que a superação do "degradante" modelo agrícola atual depende "da formação de uma consciência social ampla, crítica e ativa em prol de um projeto democrático e novo da organização sócio-econômica e técnica da agricultura brasileira" (Fórum Brasileiro de ONGs, 1992, p.115).

Ao discutirem a ampliação de um posicionamento crítico em relação ao modelo agricola dominante, alguns autores identificam dois grupos, que por sofrerem diretamente muitas das conseqüências desse modelo, estariam mais suscetíveis a esta postura: os agricultores atingidos por efeitos dos agrotóxicos e os consumidores interessados em alimentos mais saudáveis (Almeida, 1991, p.3). Surge então algumas questões: Como colocar em contato estes atores sociais com o assunto? A quem cabe tal iniciativa? Em que momento? Através de quais recursos e procedimentos?

Algumas possibilidades de respostas a tais questões são sinalizadas por Sorrentino que, ao estudar diversas iniciativas em E.A., destaca um papel importante para a educação formal e propõe "colocar a escola como centro animador de processos educativos que conciliem ensino, pesquisa e extensão na ação junto a temas ambientais presentes nas comunidades onde está inserida, provocando a construção de conhecimentos dos educadores/educandos e da sociedade e possibilitando mudanças de práticas e posturas" (1993, p.25).

A partir destes referências foi formulada uma proposta de pesquisa cujos pilhares serão formulados a seguir e representados esquematicamente no Apêndice 1. 


\subsection{OBJEtivos}

Este estudo tem para o pesquisador um duplo caráter, é fim, enquanto um "produto científico" a ser realizado no contexto de um programa de pós-graduação e, é também, um meio que colabora no sentido de seu objetivo mais geral, o qual pode ser assim explicitado:

"Estimular o questionamento do modelo agrícola convencional e a valorização de produtos e iniciativas agrícolas alternativas, como parte da busca por justiça social, pela melhoria da qualidade de vida de produtores e consumidores agrícolas e pela recuperação e sustentabilidade ambiental".

Já o objetivo científico específico da pesquisa é:

"Contribuir para ampliar os conhecimentos sobre os processos educativos que, a partir da educação ambiental, abordam as relações entre agricultura e meio ambiente procurando potencializar os educandos no questionamento da agricultura convencional e na valorização de iniciativas alternativas".

Este objetivo específico do estudo pode ser detalhado da seguinte forma:

a) Realizar um diagnóstico sucinto sobre o ensino das relações entre agricultura e meio ambiente em escolas do ensino médio;

b) Avaliar o grau de interesse, motivações, limitações e dificuldades de professores e de seus alunos num processo de ensino-aprendizagem envolvendo o assunto;

c) Discutir sobre as contribuições que a abordagem do assunto, junto a educadores e educandos, oferece à constituição de uma postura crítica diante das questões sócio-ambientais e às mudanças de práticas e comportamentos, especialmente os associados à produção e ao consumo agrícola;

d) Identificar possíveis desdobramentos de processos educativos sobre o tema;

e) Avaliar o processo de preparação e execução de uma intervenção educacional sobre $\mathrm{o}$ assunto, inclusive quanto às vantagens e desvantagens desta no contexto de uma pesquisa. Isto se associa a um objetivo prático e procedimental do estudo, a saber: "promover um curso de aperfeiçoamento de educadores abordando as relações agro-ambientais numa perspectiva de educação ambiental". 


\subsection{JUSTIFICATIVA}

Acreditando que toda pesquisa deva ser justificada científica e socialmente, e em especial aquelas promovidas no âmbito de instituições públicas ou que recebem financiamento público, a seguir são apresentados alguns pontos que justificam este estudo:

- É grande a importância social e ambiental das relações entre agricultura e meio ambiente, incluindo: desde gravíssimos riscos à saúde humana e irreversíveis degradações ambientais até a possibilidade de alternativas que buscam a sustentabilidade agro-ambiental e a melhoria da qualidade de vida.

- O sistema educativo formal possui um grande potencial para influenciar os distintos atores sociais no sentido de mudanças de posturas e comportamentos.

- Atualmente verifica-se um pequeno acúmulo teórico sobre processos educativos envolvendo as relações agro-ambientais. Segundo Alves-Mazzotti, quando se avalia a cientificidade de estudos especificos, a questão da teorização deve ser flexibilizada considerando o acúmulo de conhecimentos existentes sobre o assunto: "Em áreas 'virgens', estudos exploratórios, descritivos de um fenômeno até então desconhecido podem trazer contribuições importantes para o desenvolvimento de uma dada área de conhecimento, constituindo um primeiro passo necessário a futuras tentativas de explicação" (1998, p.127).

- Há uma necessidade de aprofundamento teórico no campo da educação ambiental.

- O estudo pode oferecer uma pequena contribuição à reflexão sobre estratégias para a reversão da atual crise do sistema público de ensino. 


\section{REVISÃO DE LITERATURA}

Este trabalho iniciou-se com a realização de revisões bibliográficas abarcando quatro conjuntos temáticos os quais compõem grande parte do objeto-processo de estudo:

a) ciência e racionalidades;

b) relações entre agricultura e meio ambiente;

c) ambientalismo e educação ambiental;

d) projetos educacionais.

\subsection{CiÊnCIA E RACIONALIDADES}

"Que tal buscarmos outro caminho? Quebrarmos a ideologia competente com uma outra forma de saber, falando e fazendo tudo quanto supostamente não temos o direito de falar, pensar e fazer? Isto é, inventarmos uma outra relação com o pensamento, com a linguagem e com a práxis?"

(Marilena Chauí. Competência. Leia Livros, n57, São Paulo:1983)

Esta pesquisa tem uma tripla relação com as questões da ciência e dos conhecimentos:

a) por ser um estudo científico exige a explicitação do referencial que lhe sustenta.

b) uma dimensão central do "objeto" de estudo são as relações agro-ambientais, as quais têm um importante componente científico (Altieri, 1989 e Gliessman, 2000).

c) outro vetor central do "objeto" eștudado é a educação formal, que tem como uma de suas principais atribuições disponibilizar os conhecimentos científicos e outros saberes para os educandos.

A seguir serão abordadas as relações ciência e sociedade, o que atinge o "objeto" da pesquisa, mas também fornece parte do referencial teórico mais amplo do trabalho. Já a discussão específica sobre o encaminhamento da pesquisa científica e seu tratamento de campo será apresentada no item Metodologia. 


\subsubsection{A CIÊNCIA MODERNA}

A maioria da elite dominante e uma grande parcela da humanidade, notadamente no Ocidente é caracterizada, entre outras coisas, por uma determinada forma de ver e compreender o mundo e a vida. Este modo de compreender, que segundo alguns autores tem forte inspiração judaico-cristã (Gonçalves, 1990), nos últimos séculos, associou-se sinergicamente com a ciência clássica, constituindo a chamada racionalidade moderna. Neste contexto ciência e racionalidade moderna se fortaleceram. A ciência assumiu uma importância muito grande para a humanidade, e em especial no Ocidente, basicamente através de dois movimentos:

i) deixou de ser apenas "um dos modos de interpretar a realidade", e assumiu-se como "o modo de conhecer a realidade". É como se a ciência fosse "um lugar de poder onde os seres humanos passaram a olhar para o mundo e a natureza" (Carvalho, 1998, p. 23).

ii) passou a contribuir cada vez mais com a produção de tecnologias. Isto aumentou o seu prestígio, realimentando a sua afirmação enquanto "o modo de conhecer".

Na tentativa de conhecer realidade a ciência clássica elegeu uma série de procedimentos, sendo os principais: a separação, a simplificação, a decomposição e a classificação dos objetos.

Partindo desta racionalidade que olha para tudo como "objetos", o princípio da simplificação remeteu à idéia de que a realidade e as coisas, enfim tudo, seria composto por unidades simples. Conforme idealizado por Rene Descartes, o Universo foi concebido como um objeto perfeito, em que a união de unidades simples, desenvolvendo funções especificas e organizadas em uma estrutura comporiam a "máquina universal". Assim os cientistas passaram a buscar as unidades elementares da realidade e as leis imutáveis que garantiriam o pleno e perfeito funcionamento desta unidade. Neste contexto a linguagem matemática foi assumida como a mais apropriada para retratar a realidade.

A ciência clássica promoveu muitas separações, como aquelas entre observador e objeto observado, entre seres humanos e natureza e entre corpo, mente e espírito. O procedimento da separação consolidou as oposições espírito-matéria e humanos-natureza mudando tanto o relacionamento como a compreensão da natureza que deixou de ser entendida como uma totalidade. 
Quase simultaneamente à construção e consolidação da mentalidade que separa os humanos da natureza, foi consolidando-se a mentalidade que sobrepõe os humanos à natureza. Francis Bacon, filósofo que viveu no século XVI, é considerado um dos fundadores do método científico moderno, defendia ele que "Devemos dominar a natureza e atrelá-la a nossos desejos", segundo ele cabe ao cientista: "extrair da natureza, sob tortura, todos os seus segredos" (Carvalho, 1998, p.31). Muitos problemas foram gerados a partir do momento em que principios e procedimentos da ciência clássica foram adotados em outras instâncias com destaque para as relações sociais e para as relações humanos-natureza. Por conta destas posturas, autores argumentam que a visão moderna de mundo, baseada na ciência clássica, promoveu o "desencantamento do mundo" (Carvalho, 1998, p.32).

Diversos cientistas, filósofos, sociólogos e outros pensadores formularam críticas à aos referenciais da ciência moderna. Uma síntese destas críticas foi apresentada por Santos de modo tão didático que aqui só cabe reproduzi-la:

(um) paradigma que se constitui contra o senso comum e recusa as orientações para a vida prática que dele decorrem;

um paradigma cuja forma de conhecimento procede pela transformação de relação eu/tu em relação sujeito/objeto, uma relação feita de distância, estranhamento mútuo e de subordinação total do objeto ao sujeito (um objeto sem criatividade nem responsabilidade);

um paradigma que pressupõe uma única forma de conhecimento válido, o conhecimento científico, cuja validade reside na subjetividade de que decorre a separação entre teoria e prática, entre ciência e ética;

um paradigma que tende a reduzir o universo dos observáveis ao universo dos quantificáveis e o rigor do conhecimento ao rigor matemático do conhecimento, do que resulta a desqualificação (cognitiva e social) das qualidades que dão sentido à prática ou, pelo menos, do que nelas não é redutível, (...) a quantidades;

um paradigma que desconfia das aparências e das fachadas e procura a verdade nas costas dos objetos, assim perdendo de vista a expressividade do face a face das pessoas e das coisas onde, no amor ou no ódio, se conquista a competência comunicativa;

um paradigma que assenta na distinção entre o relevante e o irrelevante e que se arroga o direito de negligenciar (Bachelard) o que é irrelevante e, portanto, de não reconhecer nada do que não quer ou pode conhecer,

um paradigma que avança pela especialização e pela profissionalização do conhecimento, com o que gera uma nova simbiose entre saber e poder, onde não cabem os leigos, que assim se vêem expropriados de competências cognitivas e desarmados dos poderes que eles conferem; 
um paradigma que se orienta pelos princípios da racionalidade formal ou instrumental, irresponsabilizando-se da eventual irracionalidade substantiva ou final das orientações ou das aplicações técnicas do conhecimento que produz;

finalmente, um paradigma que produz um discurso que se pretende rigoroso, antiliterário, sem imagens nem metáforas, analogias ou outras figuras da retórica, mas que, com isso, corre o risco de se tornar, mesmo quando falha na pretensão, um discurso desencantado, triste e sem imaginação, incomensurável com os discursos normais que circulam na sociedade" (Santos, 1989, p.34-35).

\subsubsection{CIÊNCIA PÓS-MODERNA}

Mas a despeito das pretensões da ciência clássica de colocar-se como detentora absoluta da verdade, outras perspectivas, princípios e interesses foram se apresentando. Já no século passado, surgiram internamente à ciência, desvios e até reações ao paradigma positivista por exemplo: a ecologia mostra a importância das relações e processos, Freud instaura uma relação sujeito-sujeito, Marx propõem uma nova relação com a realidade em que conhecimento, reflexão e ação são momentos complementares do agir humano. Mais recentemente estudos na física e na química apontaram vários problemas e limitações do paradigma moderno para a compreensão da realidade.

Ao tratar daquilo que ele denomina "ciência pós moderna" Boaventura de Souza Santos propõe a ética e o compromisso social com a verdade (possível) como orientadores da Ciência. Concebida como uma "prática social de conhecimento" o autor defende que acima do "tribunal da razão" a ciência deve submeter-se ao "tribunal do devir histórico do homem no mundo" (1989, p.25). Santos indica a "reflexão sobre a verdade social da ciência" como meio de questionar o conceito de verdade científica da ciência moderna, considerado "demasiado estreito, obcecado pela sua organização metódica e pela sua certeza, e pouco ou nada sensível à desorganização e à incerteza por ele provocadas na sociedade e nos indivíduos" (Santos, 1989, p.45).

Outra necessidade apontada por Santos (1989, p.72-3) e a de aceitar que "o conhecimento é sempre falível, a verdade é sempre aproximada e provisória". O autor defende uma "concepção pragmática de verdade" na qual o "conhecimento verdadeiro" se caracteriza por ser aquele que conscientemente guia-nos "com êxito na obtenção de um objetivo prático ou intelectual" (Santos, 1989, p.49). E lembra a proposta de ampliação do conceito de "explicação" apresentada por Anthony Giddens (citado por Santos, 1989, p.57) na qual 
explicar significa "tornar inteligíveis observações ou acontecimentos que não podem ser facilmente interpretados no contexto de uma teoria ou de um quadro de sentido existente". Seguindo semelhante raciocínio Ardoino propõe uma ampliação do sentido do verbo "analisar" como: "acompanhar o processo, compreendê-lo, apreendê-lo mais globalmente através da familiarização", explicitando e elucidando esse processo ao mesmo tempo em que ele acontece sem procurar interrompe-lo (Burnham, 1998, p.41).

Para Santos "a verdade é normativa e só existe enquanto luta de verdades", assim a argumentação diante da comunidade científica assume papel relevante na construção das "verdades provisórias". Pressupondo a negociação é proposto a seguinte concepção para objetividade: "propriedade de algo que obtém o consenso numa discussão argumentativa". Sendo o domínio da argumentação "o razoável, o plausível, o provável, e não o certo ou o falso" (Santos, 1989, p.95 e segs.).

Mas além do diálogo interno, a ciência necessita realizá-lo também com a sociedade, a fim de ser entendida e apropriada por ela. Santos propõe a construção de um novo paradigma para o conhecimento, a partir de uma dupla transformação que valoriza, engloba e supera o senso comum e o conhecimento científico. O que se pretende é constituir uma "nova configuração do saber" reunindo "um senso comum esclarecido e uma ciência prudente", de modo a dar "sentido e orientação à existência" (Santos,1989, p.41). Afinal como diz Alves (1981, p.20): "o senso comum e a ciência são expressões da mesma necessidade básica, a necessidade de compreender o mundo a fim de viver melhor e sobreviver".

Para a dupla ruptura Santos apresenta um encaminhamento:

i) "progressivamente atenuar o desnivelamento dos discursos" (entre senso comum e ciência) permitindo que "eles se falem";

ii) "progressivamente superar a dicotomia contemplação/ação";

iii) "encontrar um novo equilíbrio entre adaptação e criatividade" (Santos, 1989, p.42).

A primeira ruptura a ser feita é em relação ao senso comum, ao conhecimento vulgar, à experiência imediata, às opiniões, trata-se da construção da ciência. Ocorre que apesar do senso comum ser "o menor denominador comum daquilo em que um grupo ou um povo coletivamente acredita" possuindo "uma vocação solidarista e transclassista", a ruptura com o senso comum é necessária pois tal vocação assume "um viés conservador e preconceituoso, que reconcilia a consciência com a injustiça, naturaliza as desigualdades e mistifica o desejo de transformação" sendo portanto "o modo como os grupos ou classes subordinadas vivem a sua subordinação" (Santos, 1989, p.37). 
Porém a necessidade de romper com o senso comum não obriga a desconsiderá-lo totalmente como fez a ciência moderna, necessário seria resgatar as suas "positividades" (Santos, 1989, p.41). Afinal, por dezenas de milhares de anos os seres humanos sobreviveram baseando-se em conhecimentos que estão mais próximos da classificação "senso comum" e agora, após 4 séculos do surgimento da ciência, o que se percebe é o seu desdobramento em sérias ameaças à nossa sobrevivência (Alves, 1981, p.20).

Quanto a esta questão é pertinente destacar a prática corrente entre os agroecologistas de promover o resgate dos conhecimentos de populações e agricultores tradicionais, considerando que muitos cultivam a mesma região por dezenas e até centenas de anos mantendo um relativo equilíbrio no agrossistema, o que denota um conhecimento complexo e altamente apropriado às condições sócio-ambientais locais.

Trata-se de superar a obsessão do paradigma científico moderno por separar sujeito e conhecimento e buscar uma nova forma de relacionamento entre estes, que agregue sensibilidade e ética. A aspiração que vem configurando-se entre determinadas pessoas e grupos converge para aquilo que Brandão (1997, p.19) descreveu como a capacidade, na meditação pessoal e na prática profissional, de integrar círculos cada vez mais amplos de sensibilidades, de conhecimentos e de valores. Este parece ser o caminho proposto por Paulo Freire (citado por Gadotti, 1999, p.24) quando fala de uma "racionalidade molhada de emoção" para a qual Deleuze (citado por Carvalho, 1998, p.21). apresentou uma bela ilustração: "o conceito de pássaro deve contemplar a beleza da plumagem para além da classificação da espécie". Esta nova relação com os conhecimentos levanta a necessidade de formação de uma consciência humanista que engloba o conhecimento de nós próprios e de outras pessoas em uma "espécie de sabedoria fundamentada no amor" (Money-Kyrle citado por Tassara \& Damergiam, 1996, p.310).

Mas a concepção de mundo que reconhece e valoriza leis imutáveis, hierarquizações, harmonia no funcionamento e outras características, mostrou-se muito apropriada às elites dominantes, interessadas em justificar e manter o "status quo". Por isso, na atualidade, a manutenção do paradigma de ciência e da racionalidade que lhe dá sustentação é pensada e trabalhada. Conforme lembram Tassara e Damergiam (1996, p.292) há uma ação deliberada de propaganda que visa a "construção de uma representação social da ciência vista como naturalmente idêntica à configuração de seu domínio pela Nova Aliança aliança que se processou gradativamente entre cientistas, industriais, militares e políticos (1945-1960)". Isto é entendido como uma estratégia para "ocultar o fato da propriedade por 
seqüestro do conhecimento científico e tecnológico por forças sistemáticas" o que por sua vez sustentam "a conclusão de que esta seria a direção natural histórica do processo de produção".

Em geral, a compreensão desta situação de embate é quase inexistente entre os educadores. Ocorre que conhecimentos e interpretações da realidade são insumos básicos do educador, sendo fundamental que ele compreenda minimamente este quadro, tanto para situar-se como pessoa com para contextualizar o processo educacional que promove. Partindo deste diagnóstico e assumindo a tese de que a Escola pode oferecer uma pequena contribuição às rupturas propostas por Santos, inclusive considerando aquelas fases por ele elencada, no presente trabalho e em sua intervenção educacional a temática sobre a ciência e as racionalidades foi eleita um ponto fundamental.

\subsection{AGRICULTURA E MEIO AMBIENTE ${ }^{1}$}

Baseada no paradigma da ciência clássica, a chamada agricultura moderna ou agricultura convencional caracteriza-se pelo total confiança na capacidade de resolução dos problemas através do aprimoramento tecnológico. Instaurou-se um modelo de enfoque monofatorial no qual cada um das diversas dimensões elementos envolvidas foram tratadas isoladamente, minimizando-se e até desconsiderando-se suas interações. Tal enfoque gerou uma proposta em que as relações agro-ambientais foram artificializadas e homogeneizadas. Também as múltiplas diferenças sociais e culturais entre os bilhões de agricultores e camponeses do planeta foram desconsideradas. Este modelo apoia-se principalmente na aplicação intensiva de agroquímicos, no uso de sementes de variedades modificadas e na mecanização pesada nas atividades produtivas. Sua adoção promoveu uma crescente especialização nos campos e regiões de cultivo, sendo que a uniformidade das monoculturas passou a ser encarada como demonstrativo de eficiência e tornou-se referência.. A médio prazo esta uniformização foi constituindo-se em uma das maiores ameaças à sustentabilidade da agricultura e mesmo à biodiversidade do planeta.

\footnotetext{
${ }^{1}$ A questão das relações entre agricultura e meio ambiente foi tratada pelo pesquisador através de uma extensa revisão bibliográfica que deu origem a dois trabalhos (Rosa, 1997 e Rosa, 1998), assim o que será feito a seguir é a retomada destes trabalhos procurando identificar os aspectos mais importantes e que sejam pertinentes ao contexto do ensino formal.
} 
Diversos autores como Paschoal (1979), Graziano Neto (1986), Altiere (1989), Primavesi (1992), Rosa (1998) e Gliessman (2000) apontam que apesar do ganho de produtividade por área oferecido pela agricultura moderna, existe uma diversidade de impactos negativos que implicam na inviabilidade ecológica, agronômica, econômica e social do modelo a médio prazo (algumas décadas). Analisando os desdobramentos do predomínio da ciência e tecnologia ocidental, como modelo para o desenvolvimento rural, a pesquisadora Vândana Shiva afirma:

"a ausência de uma apreensão teórica das duas pontas dos processos tecnológicos, seu início no campo dos recursos naturais e seu fim nas necessidades humanas básicas, levou à criação do atual paradigma de desenvolvimento econômico e tecnológico, que demanda um consumo cada vez maior de recursos naturais e gera uma crescente adição de poluentes, ao mesmo tempo em que marginaliza do processo produtivo um número crescente de pessoas, desapossando-as", continua a pesquisadora afirmando que nesse modelo a "sociedade se vê cada vez mais impelida rumo a instabilidade ecológica e econômica, não havendo respostas racional e organizada para reduzir essas tendências destrutivas" (Comerford \& Grzybowski, 1992, p.5).

Entre os principais danos relacionados a este modelo destacam-se: a degradação dos solos, a contaminação dos recursos hídricos, a redução da biodiversidade (inter e intra espécies), as intoxicações de trabalhadores rurais, a contaminação e perda de qualidade dos alimentos cultivados e diversos problemas sociais.

Mas a percepção destes problemas é recente e a discussão sobre tais temas ainda está restrita a pequenos grupos e setores sociais. O que se nota é que a maioria da sociedade está influenciada pelo discurso modernizante e que o modelo "permanece profundamente enraizado na consciência social -tanto nas cidades como no campo- como referência única de progresso e modernidade" (Almeida,1991, p. 2).

A valorização e reprodução do modelo agrícola moderno, baseia-se intensamente nos meios de informação de abrangência coletiva ${ }^{2}$ (principalmente a televisão) e, geralmente, atende interesses de poderosos setores econômicos como as indústrias de insumos (agroquímicos e sementes), de equipamentos agrícolas e as empresas processadoras de produtos agrícolas. O Tratado sobre Agricultura Sustentável preparado por ONGs. de diver-

${ }^{2}$ Gutiérrez e Prado alertam para o processo de "re-semantização" empreendido pelo sistema hegemônico no qual são denominados "meios de comunicação de massa" os atuais "meios de informação de abrangência coletiva" (1999, p.88). Para facilitar, em outras partes deste texto foi usado o termo "meios de informação de massa". 
sas partes do mundo, durante a ECO/92, ressalta que o controle de conhecimentos exercido pelo poder econômico decorre de "um modelo de informação verticalmente estruturado" e "tem sido utilizado como instrumento de dominação e desinformação dos produtores rurais ..." (Fórum Internacional de ONGs e Mov. Sociais, 1992, p.144).

Muitas vezes, nesse contexto os impactos negativos das práticas agrícolas convencionais são apresentados e/ou admitidos como inevitáveis. Exemplos desse entendimento foi detectado por Guivant, ao estudar o uso e abuso de agrotóxicos percebeu que o "alto grau de confiabilidade que os agricultores manifestam em relação à eficiência de tais insumos químicos" se associava a um certo "fatalismo químico", que pode ser expresso da seguinte forma: "se se quer produtividade em determinadas lavouras, (...) não há outra forma, além desta, de garantir o investimento inicial" (Guivant, 1993, p.127).

Simultaneamente à expansão do agricultura moderna surgiram ou se consolidaram diversas propostas alternativas de agricultura. O aperfeiçoamento de certas propostas na perspectiva a longo prazo levaram à constituição do termo "agricultura sustentável", o qual se insere num processo mais amplo, ou seja, a construção e consolidação do paradigma da sustentabilidade. Um rápido histórico do desenvolvimento e uma caracterização das principais correntes de agricultura alternativa são apresentadas no trabalho de Ehlers (1996). O autor considera a noção de agricultura sustentável ainda em processo de definição, "permitindo abrigar desde aqueles que se contentam com o simples ajustes no atual padrão produtivo, até aqueles que vêem nessa noção um objetivo de longo prazo que possibilite mudan-ças estruturais, não apenas na produção agrícola mas em toda a sociedade" (Ehlers, 1996 p.130-1).

No campo das ciências a convergência de certos estudos agronômicos e ecológicos, reaproximou estas áreas e levou à constituição da agroecologia definida como "a aplicação de conceitos e princípios ecológicos no desenho e manejo de agroecossistemas sustentáveis" (Gliessman, 2000, 54). Cabe lembrar que entre os técnicos agroecologistas as dimensões sociais e culturais também são consideradas essenciais (Altieri, 1989; Vivan, 1998 e Gliessman, 2000).

O Tratado sobre Agricultura Sustentável, proposto por dezenas de organizações durante a conferência Rio-Eco/92, traz uma visão ampla e transformadora na qual a agricultura sustentável é apresentada como "um sistema de organização sócio-econômica e técnica do espaço rural fundada numa visão eqüitativa e participativa do desenvolvimento, (...) ecologicamente equilibrada, economicamente viável, socialmente justa, culturalmente apro- 
priada e orientada por um enfoque científico holístico" (Fórum Internacional de ONGs e Mov. Sociais, 1992, p.144). É este o enfoque adotado no presente trabalho.

José Eli da Veiga é um dos especialistas que considera a agricultura sustentável como um objetivo a longo prazo, para ele "estamos no início de uma longa transição agroambiental e não de uma fase de mudanças aceleradas que caracteriza as revoluções" (Ehlers, 1996, p.13). Partindo deste entendimento alguns autores colocam em discussão formas e etapas de transição, ressaltando a importância da agricultura familiar, a qual deve ser fortalecida e incentivada. (Altiere, 1989; Ehlers, 1996). Para tanto a educação assume um importante papel. Segundo Ehlers "um dos pontos fundamentais" para fortalecer a agricultura familiar é a "promoção da educação no meio rural. Não apenas do ensino técnico mas, principalmente, da educação formal." (1996, p.151).

Otro aspecto importante para os incentivadores da agricultura sustentável é quanto ao resgate dos conhecimentos dos agricultores tradicionais. Para Altiere "a busca de modelos de uma agricultura sustentável deve combinar elementos do conhecimento tradicional e do científico moderno". (1989, p.208). Semelhante opinião é compartilhada por Ehlers que considera "bem provável que a agricultura sustentável concilie (....) conhecimentos provenientes da experiência dos agricultores e da pesquisa agroecológica" (Ehlers, 1996, p.151).

\subsection{AmBientALISMO E EDUCAÇÃo AMBientAL (UMA INTERPRETAÇÃO)}

Ambientalismo e educação ambiental são palavras, propostas, conceitos e movimentos que se relacionam intensamente com o objeto-processo de estudo deste trabalho. Ocorre que estes são conceitos em construção e provavelmente nunca possuirão uma definição acabada e aceita por todos, até mesmo pela natureza dinâmica de ambos. Visando construir um referencial de interpretação sobre tais temas, inclusive a título de parâmetros para o trabalho, o pesquisador preparou um texto procurando articular conceitos e idéias e originaários de várias bases e fontes, das quais se destacam obras e textos de ambientalistas militantes e de especialistas que versam sobre Ambientalismo (Leis,1996; Viola,1992; McCormick,1992; Gonçalves,1990; Evers,1984) e sobre Educação Ambiental (Gutiérrez \& Prado,1999; Gadotti,1998; Czapski,1998; Brandão,1997; Muñoz, 1996; Novo,1996; Sorrentino,1996; Medina, 1994; Dias,1992; Fórum Internacional de Ongs. e Mov. Sociais, 1992). 


\subsubsection{AMBIENTALISMO - UMA NOVA UTOPIA ${ }^{3}$}

Simultaneamente às diversas mudanças que ocorreram no mundo nas últimas cinco décadas, em especial na economia, na geopolítica internacional e nas tecnologias (informatização, sistemas de comunicação, novos materiais, biotecnologias e outras), verificou-se o crescimento de uma série de movimentos sociais vinculados a novos princípios, valores e direitos. Constituindo-se num importante aspecto da realidade contemporânea mundial, os Novos Movimentos Sociais estão preocupados com questões relativas às mulheres, ao meio ambiente, aos direitos humanos, aos indígenas, aos deficientes físicos, aos consumidores, ao pacifismo, à pluralidade cultural, às opções sexuais e outras (Evers,1984; Touraine,1989 e outros).

O ambientalismo é um dos mais importantes movimento social contemporâneo. Apesar da existência de algumas iniciativas e grupos envolvidos com questões ambientais desde o século XIX, foi após a Segunda Guerra Mundial que aumentaram as preocupações ambientalistas. Atualmente o movimento é formado por várias correntes e apresenta um amplo leque de princípios, atores sociais (pessoas e instituições) e objetivos, incluindo desde as lutas pela manutenção de uma árvore específica numa determinada praça ou pela proteção de animais domésticos abandonados até a luta por alternativas de desenvolvimento sócio-econômico. Em sua vertente mais crítica, o ambientalismo recusa os objetivos e parâmetros do modelo de desenvolvimento atualmente predominante e defende que ele "é insustentável a médio ou longo prazo e que as transformações necessárias supõem a existência de um movimento multissetorial e global, capaz de mudar os principais eixos civilizitórios da sociedade contemporânea" (Leis, 1996).

Os mais importantes pilares e princípios da transformação proposta pelo ambientalismo, segundo a interpretação do pesquisador, são apresentados na seqüência, destacando que a maioria deles são interdependentes e complementares.

3 Neste tópico e no que trata sobre educação ambiental, os autores serão citados apenas nos casos de transcrições literais devido ao propósito de apresentar a interpretação do pesquisador sobre o assunto e também devido as dificuldades de citação no transcorrer do texto, seja pelo grande número, seja pelo texto ser composto por idéias e manifestações dos autores re-arranjadas de forma a se articularem entre si e com as demais fontes segundo o entendimento do pesquisador. 
- Valorização da vida como princípio fundamental.

- Valorização e respeito à vida humana, considerando as suas mais diversas:

- dimensões: sociais e individuais incluindo os aspectos subjetivos e afetivos.

- escalas de tempo:

passado - incluindo o resgate e valorização da história dos lugares e a recuperação e conservação de patrimônios arquitetônicos;

presente - incluindo as várias formas de liberdade e de igualdade de condições e futuro - contemplando a tentativa de garantir às gerações futuras as melhores condições de sociais e ambientais possíveis.

- necessidades: sobrevivência, prazer, afeto, espiritualidade, felicidade, convívio, etc.

- ações: trabalho, lazer, educação, etc.

- manifestações: culturais, artísticas, religiosas e outras.

Nesse contexto destaca-se uma questão: As manifestações humanas que se colocam contra a vida devem ter assegurado seu direto de expressão? Este paradoxo é apenas aparente pois se o principio fundamental é a valorização da vida, qualquer manifestação que ameace concretamente a vida é reprovável.

Em associação ao princípio de valorização da vida humana se destacam os conceitos de justiça social e de "qualidade de vida" que incluem, entre outros, os direitos à saúde, moradia, educação, autonomia, relacionamentos equilibrados (com o ambiente, com outros individuos e com a sociedade). Esta postura necessariamente passa pela valorização do "ser mais" e "estar mais" em detrimento da postura do "ter mais".

- Valorização e cuidados com as demais formas de vida e com os elementos abióticos que propiciam a vida no planeta. Este princípio se apresenta como uma contraposição ao antropocentrismo atual, associando-se a uma perspectiva biocêntrica, muitas vezes influenciada por teorias científicas como a de Gaia (a Terra como um ser vivo), pela intuição e sensibilidade e também por fundamentos religiosos.

- Outro pilar importante do ambientalismo que emerge dessa valorização da vida é a constituição de uma nova Ética a qual abarca valores e procedimentos como:

Solidariedade, Cooperação e Co-responsabilidade: os quais são princípios associados a uma intensa preocupação e compromisso com a justiça social. 
Coerência - Ressaltando a necessidade de se manter a mesma conduta em todos os momentos e espaços, desde as relações pessoais até as relações com a sociedade, passando pela familia, trabalho e comunidade.

Equidade entre os individuos, comunidades, paises, classes sociais, gêneros, raças e outros recortes. Equidade de direitos e deveres considerando: as diversas relações (desde as locais até globais), as gerações futuras, as diferenças de gênero, as condições de acesso aos recursos (naturais e artificiais), etc.

Tolerância em relação às diferenças culturais, raciais, religiosas, políticas, de comportamento social, de opiniões e outras. Nesse sentido o diálogo, a negociação, a busca de consensos e convergências tornam-se procedimentos valorizados, mas também o respeito, a valorização e a convivência das diferenças, incluindo o respeito às minorias.

- Um terceiro pilar do ambientalismo constitui-se por uma nova visão de mundo que contemple:

- Enfoque nos processos, dinâmicas e inter-relações. Considerando as diversas escalas espaciais (desde o local até o planetário) e temporais (geológico, biológico, histórico e pessoal). Considerando também as múltiplas interdependências e complementariedades que ocorrem: entre natural e artificial/cultural, entre humanos e não humanos, entre seres vivos e meio abiótico, entre países, entre povos, entre gerações, e muitas outras.

- A mentalidade planetária ou perspectiva global requer que tudo seja pensando enquanto um fenômeno ou processo inserido em algo maior: a humanidade ou o planeta

- O respeito e a valorização da diversidade cultural, ambiental, biológica, religiosa, racial, etc.

- O reconhecimento da importância das dimensões: subjetiva (ex.: sensibilidade, afetividade, estética, etc.), metafísica (em especial a intuição) e espiritual.

- Uma nova racionalidade cientifica. Parte das questões levantadas pelos ambientalistas em relação a Ciência será discutida em item específico nesta dissertação. A principal preocupação ambientalista quanto a Ciência é que o conhecimento se baseie naquela nova ética tratada acima, uma Ciência com consciência como diz Morin (1996) e se caracterize, entre outros aspectos, pelo:

Compromisso com o princípio de valorização da vida, implicando em que toda produção científica, todo conhecimento, todo saber, sirva à valorização da vida e ao crescimento humano. Brandão diz que o conhecimento científico deve ter 
"uma face voltada para a fertilização de tecnologias que possam aperfeiçoar a qualidade de nossas relações com o Mundo e entre nós próprios"(1997, p.10).

Humildade e respeito com outros saberes, considerando ciência como mais uma das formas de procurar compreender a realidade, lembrando sempre que "há outros modos de conhecer, não menos úteis, sobretudo diante de fins vitais como a felicidade" (Demo: 1994, p.21).

Inovação, criatividade e flexibilidade para contribuir nas transformações sócioambientais necessárias à busca da sustentabilidade ambiental e da justiça social.

- Novo enfoque econômico em que predomine os princípios anteriormente citados. Assim o que se busca é: maior colaboração entre empresas; produção descentralizada; eliminação da contaminação ambiental e de outros impactos ambientais (dos produtos e dos processos de produção); eliminação dos desperdícios e a redução do consumo de matérias-primas e energia; adoção de matérias-primas e processos produtivos que possibilitem (na ordem): uma maior durabilidade, o reuso, o reaproveitamento e a reciclagem; a redução das diferenças de consumo entre pessoas e entre lugares (regiões ou países) principalmente a partir da eliminação do hiper-consumo da parcela de humanos ricos, do acesso a bens essenciais a parcela de humanos miseráveis e da redução do consumo da parcela de humanos em situação intermediária de riqueza-miséria.

- Ampliação política que implica em processos de compartilhamento de poder, ampliação da cidadania, democratização e reformulação dos espaços políticos atuais (ex.: orçamento participativo, conselhos de saúde, educação e outros) e o surgimento de novos espaços políticos (nas empresas, na família), novas dinâmicas e novos atores políticos coletivos (cooperativas, associações, ONGs., etc.) que contribuiriam para fortalecer a democracia representativa e ampliar a democracia participativa, tendo como projeto de longo prazo a autogestão. Neste contexto alguns autores apontam as possibilidades surgidas com a ampliação dos meios de informação de massa e da computação como instrumentos de difusão de informações e de operacionalização de consultas populares.

- Todos estes princípios convergem para o outro principio fundamental do ambientalismo: a sustentabilidade.

Vinculada ao compromisso com a vida e com o futuro, a busca de sustentabilidade social e ambiental consolida-se através de novas visões de mundo e remete à necessidade de transformações sociais, políticas, econômicas e , talvez principalmente, subjetivas (inte- 
riores aos seres humanos). Observar que além da proteção aos recursos e condições naturais e a manutenção das diversidades biológica, cultural, étnica, religiosa, etc. há uma preocupação com suas apropriações e usos (Para quê?, Por quê? Como?, Quem ganha?, Quem perde?, Onde? Por quanto tempo?). Considerando a inadiável necessidade de reversão da degradação ambiental e de justiça social (que implica, pelo menos, na eliminação da miséria e na satisfação das necessidades básicas de todos seres humanos do planeta), os ambientalista defendem a busca pela construção de sociedades sustentáveis.

O conceito de sociedades sustentáveis é entendido como mais adequado que o de desenvolvimento sustentável pois "possibilita a cada uma delas (sociedades) definir seus padrões de produção e consumo, bem como o de bem-estar a partir de sua cultura, de seu desenvolvimento histórico e de seu ambiente naturap" (Diegues,1992, p.18). Deve ser destacado a dificuldade dessa empreitada pois a autonomia de uma sociedade está limitada ao não prejuizo das demais sociedades.

Em síntese pode-se afirmar que 0 ambientalismo propõe uma nova utopia que procura articular o meio ambiente e todos os seres humanos (inclusive os vindouros), considerando todas as suas especificidades, a fim de garantir a melhoria da qualidade de vida com sustentabilidade ambiental e justiça social.

\subsubsection{EDUCAÇÃO AMBIENTAL - UM CAMINHO}

A empreitada a ser enfrentada pelas pessoas, entidades e governantes que assumam a busca pela utopia ambientalista tende a ser muito difícil e longa. A educação e, em especial, a educação ambiental é tomada como um "instrumento" para ampliar o número e potencializar os sujeitos comprometidos com os princípios e objetivos ambientalistas, fortalecendo-os em suas lutas. Este "instrumento" não deve ser encarado como um remédio milagroso, e sim como mais um recurso a ser empregado juntamente com outros procedimentos e posturas que as mudanças pretendidas exigem. A E.A. sofre influência das diversas vertentes que compõem o universo ambientalista e de muitas propostas e enfoques educacionais. Isto faz com que a ela tenha diversas definições, propostas e procedimentos. Na seqüência serão apresentadas algumas dessas posições.

Em 1977 ocorreu na cidade de Tbilise (ex-URSS) a Conferência Intergovernamental sobre Educação Ambiental. Partindo da declaração final do evento é possivel esboçar o 
entendimento que se consolidou na ocasião, segundo o qual a educação ambiental deve "preparar o individuo, mediante a compreensão dos principais problemas do mundo contemporâneo, proporcionando-lhe conhecimentos técnicos e as qualidades necessárias para desempenhar uma função produtiva visando melhorar a vida e proteger o meio ambiente, prestando a devida atenção aos valores éticos". Ela deve também adotar um enfoque global e interdisciplinar que reconheça a interdependência entre meio natural e meio artificial procurando fomentar os sentimentos de solidariedade e responsabilidade e incentivar a resolução de problemas locais.

Em 1986, Novo acrescentava alguns principios e conceitos, numa proposta de definição na qual a E.A. aparecia como "o processo que consiste em aproximar as pessoas de uma compreensão global do meio ambiente (como um sistema de relações múltiplas) para elucidar valores e desenvolver atitudes e aptidões que Ihes permitam adotar uma posição crítica e participativa a respeito das questões relacionadas à conservação e correta utilização dos recursos e à qualidade de vida". (Novo citado por Munoz, 1996, p.30).

Durante o evento Rio-92 centenas de pessoas do mundo todo (educadores, representantes de entidades ambientalistas e representantes governamentais) se reuniram para concluir um documento que vinha sendo discutido em diversas partes do mundo, o "Tratado de Educação Ambiental para Sociedades Sustentáveis e Responsabilidade Global". Neste documento não há uma definição específica para educação ambiental, mas sim, um conjunto de considerações, dos quais o pesquisador destacou e resumiu os seguintes:

- A educação ambiental tem um compromisso de respeito a todas as formas de vida e pressupõe um processo de aprendizagem permanente que contribua para a preservação ecológica e para a transformação humana e social visando a melhoria da qualidade de vida.

- A educação ambiental tem como objetivo maior "estimular a formação de sociedades socialmente justas e ecologicamente equilibradas". Para tanto ela deve contribuir para a reavaliação de valores, ações e modelos de condutas e de desenvolvimento, buscando aumentar a consciência, a responsabilidade e a participação dos indivíduos e das coletividades na construção de seus futuros.

- O tratado defende também que a Educação Ambiental deve: - Ter como base o pensamento crítico e inovador. - Envolver uma perspectiva holística, sistêmica e interdisciplinar considerando o contexto social e histórico. - Ser assumida como um ato político baseado em valores e voltado à transformação social. - Valorizar a diversidade cultural e as diferentes formas de conhecimento. - Procurar capacitar as pessoas a trabalharem conflitos 
de maneira justa e humana. - Integrar conhecimentos, aptidões, valores, atitudes e ações. - Converter cada oportunidade em experiências educativas de sociedades sustentáveis (Fórum Internacional de ONGs e Mov. Sociais, 1992, p.193).

Outra definição considerada importante pelo pesquisador foi apresentada em 1996 por Marcos Sorrentino na qual ele afirma que o objetivo geral da educação ambiental é:

"Contribuir para a conservação/proteção do Planeta e de todas as suas espécies e para a melhoria da qualidade de vida de cada indivíduo e comunidade, através de processos educativos instigantes, interativos, holísticos e que resgatem nossas capacidades de auto-conhecimento e de autogestão política e econômica" (Sorrentino, 1996, p.18).

\subsubsection{Alguns princípios em E.A.}

Os princípios em E.A. decorrem do ambientalismo e de algumas propostas didáticopedagógicas, frutos de reflexões feitas por educadores ambientalistas ou não. Assim como é da articulação entre um aro e diversos raios que uma roda de bicicleta é composta, os princípios da E.A. se inter-relacionam e se integram criando algo novo que é maior que as partes. Continuando a analogia: da mesma forma que a roda da bicicleta não se sustenta com um ou poucos raios, um projeto educacional não pode ser enquadrado como educação ambiental, se apresentar apenas alguns principios dessa proposta. Também da mesma forma que a ausência de alguns raios, geralmente, não impede o uso da roda (ainda que precário), o mesmo pode ser dito quanto aos princípios da E.A.: é necessário a reunião de diversos elementos, mas eventualmente alguns poderão não estar plenamente presentes numa determinada iniciativa.

- Procurar adotar os princípios do ambientalismo, destacando-se aqueles anteriormente citados, como referenciais de objetivos e procedimentos em processos educacionais.

- Sempre levar em conta que os educandos enquanto indivíduos humanos possuem uma dimensão interior (subjetiva, emocional e espiritual) que abarca elementos como: amor, felicidade, prazer, criatividade, medo, paixão, desejos e muitos outros.

- Encarar os educandos não como objetos, mas como sujeitos históricos, sociais e culturais.

Considerar os educandos como sujeitos históricos implica em reconhecer que eles possuem: 
- um passado - que se traduz em um acúmulo de experiências próprias, as quais contribuíram para a consolidar de valores e para a construir conhecimentos específicos.

- um presente - em que se expressam: necessidades, interesses, potencialidades, receios, capacidades e limitações (intelectuais, técnicas, de recursos, de tempo, etc.) e outros aspectos.

- um futuro - para o qual, em geral, o educando tem uma projeção e no qual o educador deseja influenciar para que se incorpore os princípios do ambientalismo.

Por sua vez, quando se considera os educandos como sujeitos sociais, remete-se ao fato de que eles pertencem a determinadas classes e segmentos sociais e que participam em diversos tipos de sistemas, estruturas e relações sociais, políticas e econômicas (sistemas de produção e consumo; estruturas de poder e de decisão; relações familiares, com a vizinhança, com a coletividade, com a sociedade, etc.).

Encarar os educandos como sujeitos culturais significa considerar que estes possuem um acúmulo cultural constituído por uma determinada ética e por valores, hábitos, condutas, crenças, conhecimentos, representações entre outras características.

Assim a construção de conhecimentos ou a simples incorporação de informações pelos educandos será mediada, entre outros, pelos elementos acima citados. Por sua vez as decisões e atitudes dos educandos decorrerão não só dos novos conhecimentos disponibilizados pelo processo educativo, mas sim, da interação destes com os conhecimentos preexistentes e com as demais dimensões do indivíduo.

- Estimular a construção de conhecimentos que sejam relevantes para os educandos.

- Possibilitar a incorporação de valores e atitudes que incentivem a ação transformadora no sentido da promoção de sociedades justas e sustentáveis.

Os educadores ambientais propõem o desenvolvimento de processos educativas sobre novos parâmetros e recortes, se comprometendo com os sujeitos envolvidos e com a transformação. Como diz Munhoz: "O que nosso mundo necessita não é um sistema educativo orientado para a manutenção do statu quo e nem torres de marfim de aprendizagem especializada, e sim ambientes educativos flexíveis e funcionais onde os jovens e velhos possam entrar em contato com conceitos e idéias relevantes para seu presente e para seu futuro" (Munoz,1996, p. 35). 


\subsubsection{Considerações metodológicas sobre E.A.}

Em geral os educadores ambientais contrapõem-se ao ensino reprodutivista, pois consideram que o simples acúmulo de informações é insuficiente para se chegar aos objetivos do ambientalismo. Sendo necessário que os educandos construam seus próprios conhecimentos, contemplando as demandas ambientalistas e suas próprias necessidades, anseios, dificuldades, etc. Este processo requer a busca e a geração de conhecimentos críticos, indagativos, propositivos e inovadores.

A complexidade do processo de aprendizagem e de desenvolvimento humano e a intenção de que a E.A. influencie os sujeitos a empreenderem as diversas e substantivas mudanças apontadas pelo ambientalismo, obriga que o processo educativo não seja limitado à apreensão de informações e à construção de conhecimentos. Conforme alguns autores vêm defendendo é necessário que o processo educativo integre conhecimentos, sentimentos, percepções e intuições, procurando promover mudanças de valores e de comportamentos e incentivar a práxis transformadora.

Os sujeitos são elementos vitais nos processos educacionais e precisam da máxima atenção, por isso em E.A. deve-se cuidar para que as pessoas se insiram com liberdade e que vivenciem com alegria e prazer o ensino-aprendizagem. Além disso, todo processo educativo deve contribuir para ampliar o universo de compreensão, de relacionamento e de intervenção dos envolvidos. A escolha de conteúdos, procedimentos, posturas e objetivos específicos em E.A. deve sempre considerar o cotidiano e a realidade social, econômica, cultural e ecológica dos sujeitos envolvidos.

A promoção do desenvolvimento humano integral e integrado ao meio ambiente deve ser encarada como estratégia e condição para a sustentabilidade sócio-ambiental. A preocupação com o crescimento dos educandos enquanto seres humanos implica em estimular: o autoconhecimento, o resgate e valorização da identidade e a melhoria da compreensão e percepção do mundo, por conseguinte aumenta a auto-estima e a autonomia dos envolvidos. Observar que tudo isto vale tanto para os individuos quanto para as coletividades envolvidas em processos de E.A.

É preciso considerar que os indivíduos são diferentes entre si e, portanto seu contato e relacionamento com as questões ambientais serão diferentes. Conforme diz Sorrentino: "são várias as portas de acesso ao ambientalismo" (apêndice 16). Algumas pessoas são propensas a uma sensibilização via razão, outras são tocadas pela emoção ou pela percep- 
ção, há também aquelas que são movidas pela intuição. Algumas desejarão conhecer melhor porque amam, outras passarão a amar porque conheceram melhor. Estes pontos ainda são pouco discutidos ou estudados, mas é preciso que o educador ambiental os considere em seu trabalho.

Mas como transformar esta percepção, estas idéias e estes anseios em intervenções educacionais efetivas? Como a educação pode contribuir para aumentar o desejo, a motivação, a empolgação e principalmente o compromisso das pessoas e comunidades diante dos princípios e propostas ambientalistas?

Muitas vezes ensinar é concebido como "apontar caminhos". Aqui emerge um aparente problema para a E.A.: como definir precisamente um caminho, se o destino está sendo delineado? Além disso é preciso considerar que os destinos são múltiplos sejam para as pessoas, para as comunidades, para os empreendimentos ou para os países.

A noção de sociedades sustentáveis e os princípios da educação ambiental propõe que a definição dos destinos e dos caminhos seja feita de modo autônomo pelos próprios sujeitos (educadores e educandos) no transcorrer do processo. Então a essência da educação ambiental não é "apontar os caminhos" mas sim "preparar e fortalecer os caminhantes". Não qualquer tipo de caminhante, mas um caminhante solidário com os demais companheiros e outros seres vivos que vai encontrando, um caminhante que olha para frente mas também para a paisagem por onde passa, um caminhante que aprende com seus tropeços e com sua reflexão. Um caminhante que sempre tem na mente e no coração que outros depois dele estarão percorrendo caminhos semelhantes.

Em outras palavras, a educação ambiental não deve centrar seus esforços em "receitar" formas pré-concebidas de modos de vida, relacionamentos, produção, etc. pois considera-se que cabe aos sujeitos sociais (individuais e coletivos) definirem suas opções. $\mathrm{O}$ que a E.A. deve é trabalhar pelo fortalecimento dos sujeitos (auto-estima, autonomia, competências, habilidades, etc.) e suas subjetividades (valores, afetos, ideais, idéias, etc.) para que as opções sejam feitas e os objetivos sejam perseguidos.

Se o educador ambiental é um caminhante (que tem como lugar da caminhada a E.A) vale a idéia de que é ele que deve definir suas rotas. Mas todo caminhante, mesmo aquele que está perdido numa floresta, segue alguns procedimentos como: procurar pontos de referência, provisionar água se possivel, evitar as pedras escorregadias, ir marcando o caminho que percorre, etc. De forma parecida o educador ambiental pode tomar alguns cuidados e adotar certos procedimentos em sua empreitada: 
a) Considerar os princípios ambientalistas em todas as fases do processo. - Processos educativos que visam contribuir para a construção e transformação de sociedades sustentáveis devem ter como referências os princípios da EA e do ambientalismo. Um importante cuidado é orientar o processo de forma a convergir a busca de alternativas sócio-ambientais sustentáveis e as necessidades e potencialidades dos indivíduos e coletividades.

b) Planejar a proposta. Em conformidade com os princípios anteriormente apresentados, o planejamento de qualquer proposta de programas, projetos e atividades de E.A. deve envolver o máximo possível todos os agentes do processo (educandos, familiares, parceiros e comunidade local). Esta participação facilitará o atendimento de outro aspecto importante: a apreensão e consideração das demandas, possibilidades e limitações dos interessados. O planejamento de E.A. deve procurar explicitar e anunciar com clareza os objetivos gerais e específicos, as estratégias, as metodologias, as etapas e as formas de avaliação.

c) Manter a postura de flexibilidade, procurando adaptar com criatividade as planos, propostas e métodos às situações concretas.

d) Trabalhar em equipes multidisciplinares buscando o tratamento inter e transdisciplinar.

e) Trabalhar, além do racional, outras dimensões do indivíduo, principalmente: o emotivo, o sensorial, o intuitivo e o espiritual. Para tanto pode-se recorrer a procedimentos e técnicas que estimulem vivências, comunicação não verbal e contatos interpessoais. O que pode ser feito por exemplo através de atividades artísticas, culturais, esportivas, festivas e outras

f) Atentar para a escolha de temas e conteúdos de modo que estes:

- sejam interessantes, relevantes e contribuam para os envolvidos alcançarem seus objetivos;

- aumentem os conhecimentos e enriqueçam a sabedoria;

- incentivem a consolidação de valores e atitudes;

- direcionem o enfoque aos processos;

- possibilitem identificar os atores e conflitos envolvidos e as versões das partes interessadas. Neste caso um procedimento eficiente é recorrer a diversas fontes sobre o mesmo assunto. 
g) Prever momentos de avaliação durante todas as fases do processo, se possivel de diferentes formas (escrita e oral, sucinta e detalhada, específica e genérica, individuais e coletivas, auto-avaliações) e em relação aos diferentes aspectos (programa, objetivos, estrutura, conteúdos, procedimentos, educadores, educandos e outros.).

h) Registrar, o máximo possível, todas as fases dos processos educativos. Para tanto deve-se lançar mão do maior número de recursos disponiveis como: plano de atividades, caderno de registro / ata de atividades (coletivo), caderno de anotações individuais (dos educandos e dos educadores), fotografias, gravações, filmagens, etc. Os registros garantem a memória do processo, facilitam a avaliação, estimulam a reflexão e contribuem para consolidar aprendizagens (tanto no momento de produção dos registros como posteriormente).

\subsection{Projetos educacionals}

O termo "projetos" é muito empregado entre educadores, formadores de educadores e responsáveis por órgãos educacionais (ministério e secretarias de educação), porém é pequena a reflexão sobre o assunto. Desde o início do trabalho, a promoção de "projetos" constava entre os possiveis "produtos" a serem gerados no transcorrer do curso-oficina. Mas no momento dos cursistas gerarem suas propostas o pesquisador deparou-se com a complexidade do tema. Inicialmente não havia intenção de aprofundamento sobre projetos educacionais neste trabalho, mas devido ao destaque que o termo assumiu o pesquisador realizou uma pequena revisão bibliográfica que será apresentada a seguir:

Em uma breve revisão sobre "projeto" em educação, Hernández (1998) escreve que, desde o início do século, a denominação é atribuida a distintas propostas, ocorrendo, também, desde esta época discussões sobre suas configurações, vantagens e desvantagens. Avaliando algumas propostas educacionais que adotaram o termo "projeto" $\mathrm{O}$ autor destaca as interfaces que estas mantêm com trabalhos por temas, idéias-chave e currículo em espiral (Bruner), atividade e estudo do próximo (Escola Nova), aprendizagem conceitual (Dewey), estrutura das disciplinas, construtivismo, contexto de aprendizagem, participação e estratégias metacognitivas. Contextualizando os "projetos educacionais" numa tradição escolar que inclui outras propostas, o autor apresenta o quadro a seguir. 
- Ultrapassam os limites curriculares (tanto das áreas como dos conteúdos).

- Implicam a realização de atividades práticas.

- Seleciona-se temas apropriados aos interesses e ao estado de desenvolvimento dos alunos.

- São realizadas experiências de primeira mão como visitas, presença de convidados na sala de aula, etc.

- Deve ser feito algum tipo de pesquisa.

- Trabalham estratégias de busca, ordenação e estudo de diferentes fontes de informação.

- Implicam atividades individuais, grupais e de classe, em relação com as diferentes habilidades e conceitos que são aprendidos.

Quadro 1 - Caracteristicas comuns aos projetos e outras estratégias de ensino segundo Hernández (1998, p.80)

Especificamente quanto a projetos educacionais este autor identifica, entre outras, duas vertentes atualmente:

- uma abordagem que sofre intensa influência psicopedagógica e volta-se a aprendizagem de pensar criticamente, analisar, sintetizar e dar significado às informações; planejar ações; resolver problemas; criar novas idéias ou materiais.

- uma outra abordagem que atenta para a revisão do sentido do saber escolar, destaca a importância da realidade pessoal e cultural dos educadores e educandos; valoriza a atitude relacional e busca:

“a) estabelecer as formas de pensamento atual como problema antropológico e histórico chave;

b) dar sentido ao conhecimento baseado na busca de relações entre fenômenos naturais, sociais e pessoais que nos ajude a compreender melhor a complexidade do mundo em que vivemos e

c) planejar estratégias para abordar e pesquisar problemas que vão além da compartimentação disciplinar" (Hernández, 1998, p.73).

Para Hernández essa segunda abordagem de projetos implica em que o educador atue menos como autoridade e mais como guia, intérprete, problematizador e facilitador do processo. Neste contexto os projetos favorecem "situações de aprendizagem" em que os estudantes podem adquirir capacidades envolvendo: autonomia em tarefas de pesquisa; criatividade na aplicação de recursos, métodos e explicações; formulação de problemas e de diagnósticos; promoção de estratégias analíticas, avaliativas e de resolução de problemas; integração de idéias, experiências e informações de diferentes fontes; tomada de decisões; comunicação interpessoal e auto-conhecimento (1998, p.73 e seg.). 
Hernández entende que o "projeto de trabalho" não é uma metodologia didática ou uma pedagogia, mas "uma concepção de educação e da Escola" em que são valorizados, principalmente a participação do estudante (num processo que tem sentido para ele), os procedimentos de pesquisa e investigação, a compreensão, a interpretação da realidade e o enfoque relacional (1998, p.76 e seg.). A seguir é reproduzido um quadro em que o autor citado apresenta uma caracterização diferenciadora dos "projetos de trabalho":

\footnotetext{
- Parte-se de um tema ou de um problema negociado com a turma.

- Inicia-se um processo de pesquisa.

- Buscam-se e selecionam-se fontes de informação.

- Estabelecem-se critérios de ordenação e de interpretação das fontes.

- Recolhem-se novas dúvidas e perguntas.

- Estabelecem-se relações com outros problemas.

- Representa-se o processo de elaboração do conhecimento seguido.

- Recapitula-se (avalia-se) o que se aprendeu.

- Conecta-se com um novo tema ou problema.
}

Quadro 2 - Especificidades de projetos de trabalho educacional conforme Hernández (1998, p.81)

Mas o autor avalia que há uma tendência de redução dos projetos de trabalho a uma técnica e aponta algumas possíveis causas:

- na sociedade pós-industrial impera ideais pragmáticos e tecnocráticos que, quando aplicados ao processo educativo, conduzem o trabalho e procuram levar para os alunos tais ideais;

- em geral há uma busca por segurança, ordem e controle no trabalho educacional;

- muitas vezes a proposta de projetos é adotada por moda ou por ser novidade, sem que os educadores tenham construído o seu significado. O autor alerta que "fazer projetos não significa compreender a concepção educativa de projetos" (Hernández, 1998, p.79).

Segura (1999) faz uma breve revisão bibliográfica sobre projetos pedagógicos, principalmente a partir do trabalho de Boutinet (1990), identificando algumas vantagens possíveis na promoção destes:

- favorece a integração das disciplinas e a colaboração entre os educadores;

- possibilita uma leitura interdisciplinar da realidade; 
- converge interesses pessoais e coletivos, estimulando a inserção da escola na comunidade

- possibilita a inovação, a quebra da monotonia, o exercício da criatividade na ação educacional;

- contribui para a valorização e para o aumento da autonomia dos envolvidos;

- auxilia a organização do trabalho educacional através da fixação de metas e estratégias;

- estimula educadores e educandos a assumirem-se como sujeitos dos processos: educativo e social;

A mesma autora aponta, também, alguns problemas relacionados a projetos educacionais, destacando-se:

- Valorização da ação e dos produtos e descuido com a reflexão e com o processo;

- Muitas vezes os projetos são imposições do sistema educacional resultando em processos artificiais que tendem a um "enquadramento tecnocrático" (Segura, 1999, p.54).

Vasconcellos (1999) é outro autor que enfoca a idéia de projeto e aponta a existência de várias formas de se compreender e realizar projetos, apontando como a mais radical aquela que é construída pelos estudantes. Este autor fala de uma "pedagogia de projeto" que devido a participação ativa dos estudantes apresenta uma maior probabilidade de aprendizagens significativas, havendo ganhos também quanto a autonomia e a solidariedade. $O$ autor lembra que, por trabalharem problemas da realidade, os projetos são propícios à interdisciplinariedade. Este tipo de trabalho exige, entre outros, um maior grau de liberdade curricular, a disposição de materiais para pesquisa, formação adequada do professor e o descondicionamento do aluno em relação à práticas mais diretivas. $\mathrm{O}$ autor comenta alguns riscos dos projetos como: insegurança do professor; dificuldade de conectar necessidades e interesses dos alunos e a experiência acumulada pela humanidade; privar o aluno de uma sistematização do conhecimento. Vasconcellos considera importante definir claramente se a proposta nascerá dos alunos, se será uma proposta do professor ou se decorrerá de uma negociação. Observa que a participação do educador não é inibida, pelo contrário, é estimulada, considerando sua maior experiência e mais ampla visão.

Apesar de considerar que não há um modelo universal de metodologia de projetos, Vasconcellos (1999, p.154).apresenta um roteiro possivel: 
- Constituição de grupos de trabalho.

- Planejamento do trabalho pelo grupo.

- Trabalho de campo: momento em que o grupo parte para a ação a fim de ter contato com a realidade, com o problema.

- Pesquisa e teorização: trata-se do núcleo do trabalho, inclui o levantamento de hipóteses e a busca de fundamentação para avaliá-las.

- Produção de registros. Muito importante para organizar e consolidar os conhecimentos, podendo posteriormente contribuir para textos coletivos.

- Apresentação: importante para a sistematização preliminar do conhecimento e para motivação do grupo.

- Globalização: busca de uma síntese geral sobre o tema-problema trabalhado, visa a generalização do conhecimento adquirido.

- Avaliação: pode se dar em diferentes níveis como no interior do grupo, na análise crítica das apresentações do grupo e na avaliação geral do trabalho.

Nesta pesquisa e, em especial, na intervenção a ela vinculada considerou-se o termo projetos enquanto um processo-instrumento que pode ser adotado em diferentes proposta educacionais e não uma proposta didático-pedagógica em si como supõe Hernández (1998). Diferente de Vasconcellos (1999) a teorização não é assumida como o núcleo do trabalho, a princípio buscou-se ter como núcleo a criação de " situações de aprendizagem" conforme defende (Hernández, 1998). 


\section{METODOLOGIA}

\subsection{PESQUISA EM EDUCAÇÃo E A MULTIRREFERENCIALIDADE}

- A partir da década de 70 cresceu a insatisfação com as pesquisas educacionais que "não estavam levando a resultados que ajudassem a descobrir soluções para os problemas prementes, que se acumulam na área da educação" (Lüdke \& André, 1986, p.6). Aumentou a percepção que devido seu caráter histórico, complexo, multidimensional e transdisciplinar, as pesquisas científicas enfocando educação enfrentavam uma série de dificuldades e que a abordagem clássica decompondo os fenômenos e buscando tratamentos quantitativos era muito limitada. Ardoino lembra que em educação "processos e fenômenos não se encontram jamais concretamente dissociados, em estado puro, nos materiais oferecidos para a pesquisa pelas práticas sociais. Eles interagem uns sobre os outros e se desenvolvem em função uns dos outros" (1998, p.35).

Geralmente é impossivel identificar um fluxo linear de causalidade em processos educacionais, o que se tem é uma múltipla e simultânea interação de variáveis; por isso "fica difícil isolar as variáveis envolvidas e mais ainda apontar claramente quais são as responsáveis por determinado efeito" (Lüdke \& André, 1986, p.4). Por isso estas autoras avaliam que um dos desafios das pesquisas educacionais é "tentar captar essa realidade dinâmica e complexa do seu objeto de estudo" (Ludke \& André 1986, p.5). Procedimentos do tipo analítico-experimental podem até ser empreendidos em determinadas e específicas situações como parte de uma pesquisa, mas não para a totalidade de fenômenos, sob risco de simplificar tanto a realidade que implique em desqualificar o conhecimento. Neste contexto cresceu o interesse pela pesquisa qualitativa.

Bogdan e Biklen (citado por Lüdke \& André, 1986, p.11-3) identificam 5 características básicas em pesquisas qualitativas em educação: 
a) Os dados são levantados através do contato direto e prolongado do pesquisador no lugar e no tempo em que ocorre o fenômeno estudado;

b) Há uma predominância de dados descritivos;

c) A preocupação é maior com o processo do que com o produto;

d) O pesquisador procura capturar a perspectiva dos participantes;

e) Os dados são tratados numa estratégia indutiva e não há preocupação com formulação prévia de hipóteses.

Alves-Mazzotti (1998) apoiando-se em outros autores lembra o fato da educação carecer de um campo claramente definido e de teorias próprias. Esta situação obriga a pesquisa educacional a recorrer a outras áreas de conhecimento e, por vezes, a várias ciências simultaneamente, em abordagens inter ou transdisciplinar. A autora considera que este tipo de abordagem tende a enriquecer os resultados, mas recomenda uma determinada cautela na adoção de teorias diversas: "É necessário que o pesquisador esteja seguro de que as teorias utilizadas (...), não apresentam, entre si, contradições no que se refere a pressupostos e relações esperadas" (1998, p.183).

Já na "abordagem multirreferencial" as contradições e as articulações entre teorias recebem outro tratamento, conforme orienta Ardoino ela "propõem-se a uma leitura plural de seus objetos (práticos e teóricos), sob diferentes pontos de vista, que implicam tanto visões especificas quanto linguagens apropriadas às descrições exigidas, em função de sistemas de referências distintos, (...) reconhecidos explicitamente como não-redutíveis uns aos outros" (1998, p.24). A multirreferencialidade é tomada como uma metodologia (ou epistemologia) de abordagem de temas complexos que visa "ampliar a inteligibilidade, qualificada a partir de diferentes pontos de vista" (1998, p.30). Operacionalmente este autor distingue 5 perspectivas possiveis que se centram nos indivíduos, nas inter-relações, no grupo, na organização e na instituição (1998, p.30), mas lembra que a sintese dessas vertentes, a partir de um só referencial e uma só linguagem, apresenta graves riscos de mutilação da realidade, pois "não haverá jamais um esperanto das ciências" (1998, p.35). Propõe então a pluralidade de linguagens descritivas próprias aos diversos ângulos, óticas e perspectivas adotados, procurando "conjugar sem confundi-las, a explicação e a compreensão" (1989, p.38).

Burnham (1998) é outra autora que considera a perspectiva da multirreferencialidade capaz de contribuir para a pesquisa educacional, em função de sua abertura para trabalhar a grande variedade de expressões (linguagens, valores, crenças, etc.) que ali ocorrem. Argumentando no sentido da qualidade deste procedimento Colon escreveu: " $A$ inteligibida- 
de dos fenômenos passa pela aceitação do fato de que teorias, às vezes contraditórias, colaboram para compreender o objeto considerado, desde que se tome o cuidado de distinguí-las e de conjugá-las (1998, p.157). Para Ardoino o emprego de múltiplas perspectivas é apresentada como uma possibilidade de aumentar a qualidade geral da pesquisa na medida que "essas perspectivas se questionam entre si, tanto quanto, senão mais do que, interrogam o objeto que as mobiliza" (1998, p.37).

Em síntese pode-se dizer que reconhecer a complexidade de um objeto-processo de estudo e buscar compreende-lo através do conceito de multirreferencialidade implica, entre outras coisas, em:

a) considerar as interdependências entre todos os fenômenos nele implicados, inclusive as relações da parte com o todo e vice-versa (Martins, 1998, p.24);

b) aceitar a necessidade de se pensar os diversos aspectos do tema de forma complementar e dialética e

c) reconhecer a incontornável incompletude do estudo, na medida em que se aceita que uma realidade complexa é constituída por uma "multiplicidade de esclarecimentos, sempre incompletos, nunca redutiveis (Macedo: 1998 p.59).

\subsection{A PESQUISA-AÇÃO}

Considerando os objetivos, os questionamentos da pesquisa e as preocupações científicas anteriormente discutidas passou-se ao planejamento da parte de "campo" (coleta de dados). Três possibilidades eram percebidas: i) enfocar uma iniciativa já ocorrida; ii) acompanhar cientificamente uma ou mais iniciativas educacionais que já estivessem ocorrendo; iii) promover e acompanhar cientificamente uma iniciativa educacional.

Desde o início dos trabalhos, a terceira opção era avaliada como a mais apropriada e rica, pois permitiria ao pesquisador maior "controle" sobre o processo, incluindo a definição do enfoque e dos princípios educacionais da intervenção (educação ambiental), a temática (relações agricultura e meio ambiente) e os objetivos (pró transformações agroambientais). Mas esta opção também implicou em dificuldades. Ocorre que, conforme lembrado por Burnham (1998, p.46) são recentes as pesquisas educacionais "no e do cotidiano escolar, que tentam penetrar a e na escola, a partir de e com os próprios sujeitos que 
ali interagem, procurando investigar do ponto de vista destes, os múltiplos referenciais que orientam as suas ações" , o que remete a carência de instrumentais de pesquisa.

A operacionalização do trabalho de campo deu-se através de uma adaptação da denominada "pesquisa-ação", conforme apresentada por Thiollent (1984 e 1985). Segundo este autor a pesquisa-ação pode ser definida como "um tipo de pesquisa social com base empírica que é concebida e realizada em estreita associação com uma ação ou com a resolução de um problema coletivo e no qual os pesquisadores e os participantes representativos da situação ou do problema estão envolvidos de modo cooperativo ou participativo" (1985, p.14). Promovida junto a situações reais e não em situações de laboratório a pesquisa-ação é "concebida principalmente como metodologia de articulação do conhecer e do agir" (1985, p.100) que procura dar conta das transformações das situações observadas (1984, p.93). Abrangendo ações de caráter social, educacional, técnico ou outro, a pertinência da pesquisa-ação limita-se a uma faixa intermediária que congrega grupos, instituições e coletividades de pequeno ou médio porte $(1985$, p.7).

Thiollent acredita que com a pesquisa-ação "os pesquisadores em educação estariam em condição de produzir informações e conhecimentos de uso mais efetivo, inclusive ao nível pedagógico". A ação é inserida na pesquisa a fim de aumentar o conhecimento dos pesquisadores e de propiciar "aos pesquisadores e grupos de participantes os meios de se tornarem capazes de responder com maior eficiência aos problemas da situação em que vivem, em particular sob a forma de diretrizes de ação transformadora" (1985, p.16).

Detalhando a proposta Thiollent defende estudos mais qualitativos e a "flexibilização do raciocínio hipotético", assim são selecionados problemas "cujas possíveis soluções, num primeiro momento são consideradas como suposições (quase-hipóteses) e, num segundo momento, objeto de verificação, discriminação e comprovação em função das situações constatadas". As quase-hipóteses tornam-se orientadoras na busca de informações pertinentes e de argumentações necessárias "para aumentar (ou diminuir) o grau de certeza que podemos atribuir a elas" (Thiollent, 1985, p.33-35). Neste contexto os "procedimentos argumentativos" são valorizados e defendidos em vários momentos na pesquisa-ação:

“a) na colocação dos problemas a serem estudados conjuntamente por pesquisadores e participantes;

b) nas 'explicações' ou 'soluções' apresentadas pelos pesquisadores que são submetidas à discussão entre os participantes;

c) nas 'deliberações' relativas à escolha dos meios de ação a serem implantados; 
d) nas 'avaliações' dos resultados da pesquisa e da correspondente ação desencadeada". Considerando a dificuldade em definir "instrumentos" precisos para "medir" os fenômenos sociais o autor defende "a apreciação em escalas 'grosseiras' do tipo forte-fraco, grande-médio-pequeno, aumento-diminuição, etc." (Thiollent, 1985, 31).

Argumentando que a objetividade "pode ser parcialmente respeitada por meio de um controle metodológico do processo investigativo e com o consenso de vários pesquisadores acerca do que está sendo observado e interpretado", Thiollent defende a qualidade científica da pesquisa-ação de forma categórica: "a pesquisa-ação não nos parece menos exigente do que outros procedimentos e, sem dúvida, exige muito mais disciplina intelectual do que os pacotes de perguntas da comum pesquisa de opinião" (1984, p.87).

Outra observação de Thiollent que interessa ao contexto do presente trabalho é a avaliação de que a pesquisa-ação pode ser concebida "como procedimento de natureza exploratória", sendo seus resultados úteis para desencadear outras pesquisas (1984, p.99).

Thiollent (1984 e 1985) também defende que o problema da pesquisa deve surgir do grupo envolvido ou pelo menos com ele. No presente estudo o encaminhamento foi diferente pois o pesquisador já tinha os seus problemas relativamente delineados e um dos objetivos da intervenção era exatamente o de fazer com que os envolvidos incorporassem um determinado problema. Sendo que o enfoque do trabalho recaiu tanto sobre o processo de problematização junto aos participantes (conduzido na forma de uma intervenção educacional), como sobre suas reações e respostas. Mas assumindo que o procedimento defendido por Thiollent deve-se a um cuidado no sentido da pesquisa ser relevante aos participantes, pode-se dizer que no caso isto foi atendido pois o grupo formou-se a partir de voluntários que se prontificaram após terem contato com a proposta geral do trabalho.

\subsection{O ENCAMINHAMENTO DO TRABALHO}

Apesar da promoção e acompanhamento da intervenção ser um importante procedimento na pesquisa, vários outros encaminhamentos foram empregados. A figura 1 e a descrição a seguir procuram esclarecer sobre o desenrolar da pesquisa: 
SITUACÃ̃O INICIAL

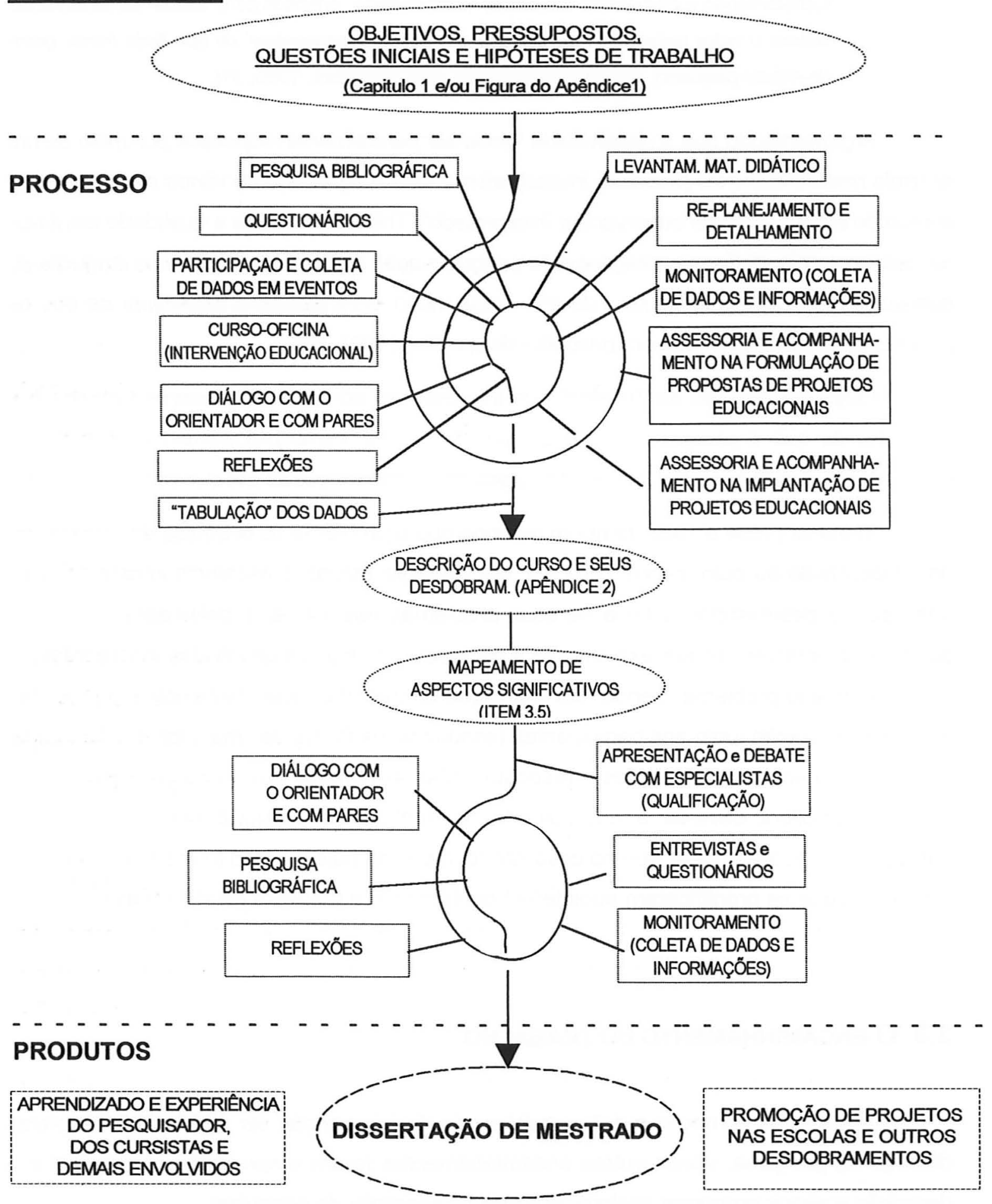

FIGURA 1 - REPRESENTACÃO GRÁFICA DO ENCAMINHAMENTO DA PESQUISA 
Os principais passos do trabalho foram:

$>$ Revisão bibliográfica inicial.

$>$ Produção dos textos sobre Educação Ambiental e sobre Ambientalismo (item 2.3), utilizados como orientadores no encaminhamento da pesquisa e da intervenção.

$>$ Planejamento geral do curso-oficina (fl.4 do apêndice 2) e detalhamento do programa do módulo 1.

$>$ Simultaneamente ao detalhamento inicial, o pesquisador escolheu a localidade em que se realizaria o curso, para tanto foram elencados alguns critérios: i) desenvolvimento do trabalho em uma região com dinâmica sócio-econômica vinculada a atividades agrícolas; ii) possibilidade de um apoio institucional (escolas, prefeituras e outros parceiros); iii) preferência por grupos de educadores oriundos de uma mesma escola, por conta de uma avaliação de que isto fortaleceria os encaminhamentos.

A região de São Roque (SP) e vizinhança foi avaliada como adequada à promoção do trabalho, enquadrando-se nos critérios anteriormente definidos, com destaque para:

a) grande contribuição da região na produção estadual de hortaliças;

b) a região faz parte do Cinturão Verde da Região Metropolitana de São Paulo;

c) existência de apoio da Oficina Pedagógica da Diretoria Regional de Ensino;

d) possibilidade de aproveitamento das instalações da Estação Experimental Agrícola da Secretaria Estadual de Agricultura e Abastecimento (CATI);

e) menor custo para a pesquisa em relação a outras opções.

$>$ Promoção de uma palestra de divulgação do curso e da pesquisa. O objetivo da atividade foi possibilitar ao pesquisador uma aproximação com o público a ser envolvido e permitir aos eventuais interessados um contato pessoal com o propositor e a obtenção de mais informações sobre a proposta e o tema. Para a divulgação do evento foi enviado um mini-cartaz (Apêndice 4) para todas as escolas de ensino médio da região. Ocorre que na ocasião $85 \%$ dos presentes era de lbiúna, cidade distante $18 \mathrm{Km}$. Como Ibiúna satisfazia os pré-requisitos da pesquisa, o curso foi transferido para lá.

> Celebração da parceria com Diretoria Regional de Ensino de São Roque e formatação da proposta de curso no padrão da Secretaria Estadual de Educação (SP).

$>$ Realização de uma intervenção educacional (detalhada no item 3.4) incluindo mais de 50 ocasiões de contatos pessoais com um grupo de educadores, foi composta por: 
$>$ Promoção de um curso-oficina de 15 encontros-aulas (detalhado no Apêndice 2).

$>$ Orientação e apoio, através de mais de 10 reuniões, para a elaboração dos projetos de educação ambiental desenvolvidos por 4 equipes de escolas diferentes.

$>$ Colaboração e acompanhamento na execução de três projetos educacionais:

a) Participação em mais de 10 reuniões com parceiros dos projetos (Prefeitura, empresas, Polícia Florestal e outros).

b) Realização de aproximadamente 12 atividades com estudantes tais como: palestras, monitoria de trabalhos de campo e oficinas sobre meio ambiente e reuniões.

c) Apoio à apresentação dos projetos em eventos promovidos pela Prefeitura de Ibiúna, pela Diretoria de Ensino, pelo Depto. de Geografia-USP e pelas próprias escolas (8 ocasiões).

D Aplicação de um questionário junto aos participantes da palestra de divulgação do curso (Apêndice 25).

$>$ Observação e produção de diversas formas de registros sobre as atividades acima citadas, incluindo anotações em caderno de campo, fotografia, gravação de áudio em fita cassete, filmagem em vídeo, fichas de avaliação, cartazes e painéis de diversas atividades.

$>$ Levantamento do perfil dos educadores-cursistas abarcando aspectos como interpretações sobre a problemática ambiental e conhecimentos e experiências em educação ambiental. Realizado nos primeiros encontros este levantamento teve como um instrumento eficiente o exercício de reflexões e apresentações através de arte (Apêndice 5). Também foram promovidos questionários (Apêndice 25) e auto-avaliações e avaliações das atividades pelos cursistas (exemplos Apêndices 12 e 15).

$>$ Promoção de reflexões e debate com especialistas sobre o encaminhamento do curso.

$>$ Levantamento de dados e informações sobre educação (principalmente no estado de São Paulo) e educação ambiental junto a diversas fontes. O pesquisador recorreu a diversas fontes e procedimentos: estágio em escola da rede pública; participação em grupos de estudos e pesquisa ligados ao Laboratório de Educação e Políticas Ambientais (ESALQ-USP) e ao Laboratório de Pesquisa em Ensino de Ciências Humanas (Faculdade de Educação-USP); participação em eventos de educadores como: Encontro 
Estadual: Educação, Ensino e Trabalho (Depto. de Geografia-USP) e o Encontro Paulista de Educação Ambiental (Fundação Santo André) e revisões bibliográficas (por exemplo: Segura: 1999 e Brasil, 1999).

$>$ Sondagem quanto aos processos educativos sobre as relações agro-ambientais voltados ao ensino médio, promovidos nas principais organizações que trabalham a temática: universidades, órgão governamentais de pesquisas e extensão, organizações não governamentais ligadas à agricultura alternativa. (pesquisa internet, visita à biblioteca da consulta junto a membros da Comissão Técnica de Agricultura Ecológica (Secr. Estadual de Agricultura).

$>\quad$ Participação em diversos encontros, seminários, feiras e outros eventos sobre educação, educação ambiental e agricultura sustentável, destacando-se dois Encontros de Educação Ambiental na Agricultura (ver apêndice 32)

$>$.Visita a uma Escola Técnica Estadual Agrícola (Itú-SP), que desenvolve projetos de agricultura alternativa e participação em uma reunião pedagógica sobre projetos de educação ambiental promovida pela rede de escolas técnicas.

$>$ Levantamento, tabulação e análise preliminar dos múltiplos registros executados durante a intervenção.

$>$ Produção do memorial descritivo e avaliativo sobre o curso-oficina e o planejamento e execução dos projetos educacionais (Apêndice 2), no qual é possível verificar os objetivos específicos; os procedimentos principais; a programação detalhada e comentada de todas as aulas e relatos do desenrolar do curso e alguns de seus desdobramentos.

$>$ Produção do "mapa de aspectos significativos da intervenção" e redação do texto com considerações sobre tais aspectos, conforme detalhado no item 3.5.

$>$ Questionários, entrevistas e reunião de avaliação e encaminhamento os com ex-cursistas.

$>$ Levantamentos de publicações envolvendo a temática.

Produção do relatório de qualificação no Programa de Pós-graduação.

$>$ Apresentações sobre o trabalho e seus resultados junto as especialistas do LEPA-USP e durante a banca de qualificação do mestrado.

$>$ Produção de relatórios descritivos e avaliativos para o órgão financiador.

$>$ Revisão e conclusão da dissertação. 


\subsection{A INTERVENÇÃO EDUCACIONAL - UM RECURSO DE PESQUISA}

A intervenção educacional, promovida enquanto recurso metodológico de pesquisa, foi composta pela realização de um curso de aperfeiçoamento de educadores e pelo apoio à formulação e implementação de quatro projetos educacionais em escolas da Rede Estadual de Ensino (SP). Metodologicamente a intervenção não pode ser considerada um "experimento" em seu sentido clássico, pois não havia intenção deste tipo de tratamento, nem condições de controle fino sobre o processo. Porém é possível identificar um procedimento "quase-experimental" (Thiollent, 1985) em que uma iniciativa envolvendo o objeto-processo de estudo e orientada por "hipóteses de trabalho" foi promovida e monitorada pelo pesquisador. A pesquisa também não é um "estudo de caso" conforme caracterizado por Lüdke \& André (1986), mas apresenta alguns aspectos e procedimentos deste tipo de abordagem.

Apesar da descrição e reflexão sobre a intervenção ter um peso importante no trabalho, ela não é o "objeto" da pesquisa, mas sim parte dele. Para a pesquisa a intervenção foi simultaneamente:

i) a principal estratégia científica para operacionalizar os trabalhos de campo, a qual, através da práxis e da ampliação dos sujeitos envolvidos, colaborou para formular respostas às questões iniciais e para aumentar a confiabilidade do estudo.

ii) um caso significativo envolvendo o objeto-processo de estudo constituindo-se no principal gerador de subsídios empíricos para a pesquisa.

Por conta da metodologia, o pesquisador desempenhou um papel importante enquanto "sujeito-ator" ativo diante do "objeto-processo" estudado. No âmbito do curso e para efeito das muitas interfaces que ele criou (por exemplo com a Diretoria Regional de Ensino/Secretaria Estadual de Educação), o pesquisador assumiu a função de coordenador. Do ponto de vista do estudo científico o procedimento do pesquisador diante da intervenção foi o de monitorar, subsidiar, avaliar, refletir, realimentar, reformular e reavaliar a iniciativa e seus desdobramentos.

Configurou-se assim uma situação de enfrentamento concreto das interrogações iniciais do estudo, podendo-se tomar a proposta e o encaminhamento do curso como um tipo de resposta à questão "Q3". O desenrolar dos trabalhos obrigou o pesquisador a propor, avaliar, rever e reformular os pressupostos, as hipóteses iniciais e as respostas preliminares da pesquisa. Neste contexto o estudo assumiu, também, um caráter de auto-avaliação 
da atuação do pesquisador, seja enquanto interprete de um conjunto de referenciais teóricos sobre educação ambiental e sobre as relações agro-ambientais (explicitados nesta dissertação, principalmente na revisão bibliográfica), seja como educador que planejou, coordenou e ministrou um curso.

A intervenção educacional atingiu diretamente, de modo intenso e diferenciado 30 educadores, sendo: 19 professores, 5 coordenadores pedagógicos, 6 diretores e uma assistente técnico-pedagógica (ATP). A maioria deste grupo era composta pelos participantes do curso (18 professores, 3 coordenadores pedagógicos e a ATP) e os demais foram envolvidos por conta dos projetos nas escolas. Foi com estes sujeitos que houve maior relação e sobre os quais incidiu o principal enfoque da pesquisa. Também é possivel apontar um outro grupo de aproximadamente 20 pessoas que participaram de pelo menos uma aula ou oficina do curso ou tiveram uma atuação mais expressiva nos projetos das escolas. Ao final somaram-se mais de cinqüenta (50) "idas a campo" e conseqüentemente contatos pessoais do pesquisador com estes educadores e com muitos de deus alunos.

Observar que, desde o início, os cursistas e outros participantes tiveram ciência da situação de pesquisa em que estavam inseridos. Mais que isto, o planejamento inicial do estudo previa e o pesquisador explicitou junto aos educadores-cursistas a intenção de que estes se incorporassem ao processo também como pesquisadores colaboradores. $O$ que forjou um novo questionamento:

É possivel a atuação dos educadores da rede pública enquanto pesquisadores colaboradores em uma pesquisa cientifica?

\subsubsection{O CURSO-OFICNA}

O curso, obviamente, foi planejado e executado a partir do mesmo referencial teórico e buscando o mesmo objetivo geral da pesquisa. Visando um comportamento ativo dos cursistas, o processo foi configurado como um "curso-oficina" cuja estrutura geral consta no Apêndice 3 e a descrição detalhada no Apêndice 2.

O curso-oficina baseou-se em múltiplos procedimentos destacando-se: promoção de 10 eventos (palestras, aulas expositivas e oficinas) com diferentes especialistas ${ }^{4}$, pes-

\footnotetext{
${ }^{4}$ Todos os especialistas convidados eram profissionais com grande experiência na área sócio-ambiental, quase todos acumulando especializações em temas agrícolas, florestais e ou em educação ambiental.
} 
quisas sobre temas locais; apresentações orais sobre leituras e discussões; debates; leituras e resenhas prévias de textos; relatos de experiências pessoais; produção individual e coletiva de painéis artísticos temáticos; produção coletiva de textos, relatórios e painéis; auto-avaliações; avaliações individuais e avaliações coletivas, planejamento participativo da programação; vivências e atividades envolvendo estímulos senso-perceptiveis, trabalhando o cotidiano, a tomada de depoimentos, o manuseio de terra e outras situações práticas.

Partindo do entendimento de que valorizar a autonomia e trabalhar pelo fortalecimento dos sujeitos (individuais e coletivos) são objetivos centrais da Educação e essenciais para que os educandos assumam-se como agentes transformadores. Como lembra CarvaIho (2000) a sensibilização, a tomada de consciência da importância do tratamento do tema ambiental e mesmo o envolvimento não são suficientes, é necessário que o educador esteja preparado e instrumentalizado. Toda a programação do curso visou colaborar com o aumento da autonomia relativa e da capacidade de reflexão e ação dos envolvidos e incluiu estratégias visando o aperfeiçoamento de competências e habilidades, o fornecimento de subsídios para a constituição e o refinamento de repertórios; a criação de situações para os cursistas expressarem e defenderem suas posições; a realização de discussões sobre o encaminhamento do curso, a promoção de avaliações sistemáticas; a interpretação de textos; a execução de diagnósticos e pesquisas locais; a produção de textos (apêndices 8 e 13) e outros procedimentos como os descritos a seguir.

Um princípio importante aplicado ao curso foi o de considerar e trabalhar a dimensão subjetiva (pessoal e interior) dos envolvidos o que inclui as emoções, os sentimentos ${ }^{5}$, os valores, a auto-estima, os desejos, as expectativas, o prazer, a criatividade e outros aspectos e manifestações individuais.

Uma grande preocupação relacionada à subjetividade dizia respeito ao fortalecimento da auto-estima dos participantes e esteve presente:

- Nas intenções implícitas do trabalho em contribuir para o resgate da auto-estima dos estudantes agricultores e dos agricultores em geral.

- Na estratégia de valorização dos conhecimentos e iniciativas dos educadores.

\footnotetext{
${ }^{5}$ Rene Barbier (1998, p.173) apresenta a seguinte interpretação: "A tradição filosófica distingue emoção, sentimento e paixão. A paixão é uma afeição durável da consciência que polariza todas as outras. $A$ emoção não passa de tempestade passageira, resultante do impacto imprevisto de uma situação problemática. O sentimento é uma disposição afetiva, menos descomedida e excessiva do que a paixão e mais durável que a emoção".
} 
- Nos objetivos ou intenções gerais dos projetos educacionais propostos pelos educadores-cursistas.

Note-se que no trabalho além da auto-estima individual estava suposta a possibilidade de fortalecimento da auto-estima de atores coletivos, tais como as equipes de cada escola, a turma de cursistas e a comunidade, em especial o segmento dos agricultores.

Visando formar e ou consolidar as equipes em cada escola (atores-coletivos), estimulou-se o fortalecimento das relações interpessoais através da criação de situações e condições de trocas, tais como apresentações de caraterísticas pessoais, atividades artísticas, debates e trabalhos em grupos (Exemplos: Encontros 1, 3, 6, 7 e 8 - Apêndice 2). Considerando as diferenças de perfis dos educandos (extrovertidos ou introvertidos, mais experientes e menos experientes, formação em diferentes áreas, etc.) e a recomendação de que na educação deve-se "fazer da diversidade um fator positivo de compreensão mútua entre indivíduos" (Delors, 2000, p.52), procurou-se garantir a participação de todos, como a formação de pequenos grupos de discussão e a promoção de rodadas gerais de manifestações. A denominação "encontro" para cada aula passou a ser usada em meados do curso como mais um elemento colaborador na construção de um espaço de diálogo.

A idealização e realização de produtos educacionais foram tomados como recursos educacionais e também como procedimentos de valorização e fortalecimento dos envolvidos. No desenrolar do curso delineou-se a opção por realizar estes produtos no formato de projetos educacionais, assim foram empreendidos vários procedimentos visando fortalecer a iniciativa:

i) um conjunto de atividades conduzido pelo palestrante do $8^{\circ}$ Encontro composto por apontamento de iniciativas exemplares; levantamento dos sonhos dos envolvidos; exercício deprojeções e outras estratégias de visualização das dificuldades e limitações dos ante-projetos (Apêndice 2).

ii) Acompanhamento individualizado junto a cada equipe para a formulação das respectivas propostas. Nas reuniões de detalhamento dos projetos das equipes o coordenador, apoiando-se em um roteiro de questões para formulação de projetos ${ }^{6}$ (Apêndice 34), provocou reflexões e estimulou a verbalização de alguns tópicos considerados imprescindíveis entre eles: objetivos gerais, objetivos educacionais, justificativa, métodos, etapas e recursos.

\footnotetext{
${ }^{6}$ Adaptado pelo pesquisador a partir de roteiros para elaboração de projetos ambientais. Posteriormente reformulado e ampliado resultou em um sub-produto da pesquisa distribuído aos participantes.
} 
iii) Ainda na etapa de planejamento dos projetos o coordenador insistiu na necessidade de formulação de propostas escritas justificando que isto:

- Possibilitaria maior clareza dos objetivos, maior integração da equipe e a equalização dos discursos;

- Facilitaria o contato com eventuais parceiros;

- Orientaria os envolvidos inclusive diante dos imprevistos e das dificuldades;

- Seria um excelente documento histórico, contribuindo para a memória do processo;

- Constituiria uma importante fonte para avaliações.

iv) Visando valorizar e fortalecer os projetos e seus agentes, foram incentivadas apresentações dos mesmos em eventos tanto de caráter educacional (Encontro Estadual: Educação, Ensino e Trabalho) como de enfoque agrícola (Exposição Agro-Industrial de Ibiúna). Os projetos também foram apresentados em eventos promovidos pelos próprios cursistas (Sala da Agricultura na Exposição Ecológica, Festival de Meio Ambiente e Evento de Lançamento Oficial do projeto) e o Encontro Educação e Desenvolvimento Sustentável em Ibiúna.

Também com o intuito de fortalecer os envolvidos, no transcorrer e após o curso estimulou-se a reflexão, o posicionamento e a produção teórica, através de diversos procedimentos como por exemplo: i) atividades durante os encontros (Apêndice 5 e 6); ii) distribuição de textos problematizando cada um dos projetos promovidos nas escolas (Apêndice 22); iii) distribuição de texto convidando os cursistas a redigirem relatórios e reflexões sobre a experiência do curso e da promoção de projetos (Apêndice 29); iv) Entrega, para cada cursista, do Memorial do curso-oficina (Apêndice 2) juntamente com um questionário; v) reuniōes de avaliação. Em dezembro de 2000, após várias tentativas, foi realizado um encontro com a maioria dos cursistas, onde o pesquisador apresentou algumas considerações sobre a pesquisa e estimulou o debate sobre alguns resultados desta, em especial quanto à questão do encaminhamento dos projetos.

Conforme defendeu uma palestrante durante o curso: "a apresentação da agricultura alternativa deve ser contextualizada a partir de uma nova compreensão da realidade e em especial da vida". Uma das mais importante estratégia educacional promovida no curso foi a contextualização do assunto diante das proposições ambientalistas e dos novos paradigmas de racionalidade e de ciência, a fim de estimular a construção de novos olhares, novas perspectivas e novas compreensões do mundo. Os principais procedimentos para isto foram: 
a) o conjunto de atividades composto de observação do entorno, caminhada nas proximidades da escola, registro das observações, discussão em grupos sobre o observado, produção e apresentação de representações gráficas sobre as observações do grupo e debates sobre as observações e sobre as representações feitas a partir destas (Encontros 7 e 9 - Apêndice 2).

b) o exercício baseado na pergunta: " $O$ que me faz um(a) professor(a) preocupado (a) com a questão ambiental? O que incluiu formulação de respostas, confecção de cartazes artísticos, apresentações, debates e avaliação posterior da atividade (Encontros 1 e 2 - Apêndice 2).

c) a palestra com uma educadora sobre visão holística (Encontro 4 - Apêndice 2).

d) a palestra-oficina com um médico homeopata que: i) tratou sobre o conceito de "convencional"; ii) fez comparações entre: visões convencionais e alternativas na medicina e na agricultura e iii) destacou a importância da percepção sensorial e dos sentimentos na vida humana (Encontro 10 - Apêndice 2 e Apêndice 19).

e) a visita a estabelecimentos onde se pratica agricultura orgânica. A ocasião foi enriquecida por diversas atividades como mini-palestra com um produtor; depoimentos e explicações de dois produtores (os quais apresentavam posturas diferenciadas: um mais idealista e outro mais pragmático); depoimentos dos familiares de um produtor; observações dos campos de cultivo, dos equipamentos, das instalações e de algumas práticas orgânicas; explicações da agrônoma que acompanhou o grupo em um dos estabelecimentos e compra de produtos orgânicos diretamente do produtor.

Desde os primeiros encontros a postura do coordenador e dos cursistas buscou incluir novos participantes, para tanto adotou-se vários procedimentos e estratégias:

- outros educadores foram convidados para assistirem palestras e para participarem do curso;

- nas reuniões de detalhamento dos projetos foram envolvidos novos colaboradores (professores e coordenadores pedagógicos);

- professores não pertencentes às equipes foram convidados a colaborarem nas atividades dos projetos;

- alunos foram convidados a participarem de uma aula do curso de aperfeiçoamento (oficina sobre viveiros e mudas de árvores);

- eventos e atividades dos projetos foram programadas visando abarcar o maior número possível de alunos. 


\subsection{MAPEAMENTO DE ASPECTOS SIGNIFICATIVOS PARA PESQUISA}

Ao concluir a fase principal de coleta de dados (curso-oficina) o pesquisador

- diante da complexidade do tema;

- considerando a riqueza e diversidade de dados disponíveis;

- influenciado pela proposta de abordagem multirreferencial;

- considerando a importância da argumentação nas ciências sociais;

- encorajado pelas reflexões e posições de Tassara (1996; 1997 e outros),

- promoveu um procedimento para auxiliar o processamento (tabulação) e a inter-

pretação dos dados e informações, conforme será indicado a seguir:

a) Inicialmente o pesquisador fez uma releitura das bases de dados que incluía: o projeto de pesquisa; as anotações do caderno de campo; as reflexões feitas no decorrer dos trabaIhos; as tabulações e análises preliminares dos questionários; os produtos dos cursistas (projetos, relatórios, avaliações, etc.); algumas transcrições de falas dos envolvidos e, em especial, o Memorial do Curso-oficina.

b) Através desta releitura foram identificados assuntos, conceitos, aspectos, propostas, etc. que se destacaram ou que foram considerados significativos para a formulação de respostas às questões iniciais da pesquisa e de outras surgidas no processo. A seleção destes pontos de destaque ou significativos teve como orientadores os objetivos e questões da pesquisa e os referenciais teóricos iniciais e como critérios a "freqüência", a "importância" e o "potencial explicativo" do dado em relação ao objeto-processo estudado.

c) Para efeito de sistematização e considerando a dificuldade de isolar vários destes aspectos, os mesmos foram agrupados em famílias ${ }^{7}$ compondo a "versão inicial do mapa dos aspectos significativos na intervenção" (apêndice 31).

d) Em seguida, a base de dados citada no item (a) foi revista visando: i) confirmar os aspectos significativos "mapeados", implicando em algumas alterações e rearranjos destes e ii) subsidiar a caracterização destes aspectos. Este procedimento converge com o proposto por Lüdke \& André que sugere "a construção de um conjunto de categorias descritivas" através da leitura e releitura dos dados "até chegar a uma espécie de impregnação do seu conteúdo" (1986, p.48).

\footnotetext{
${ }^{7}$ O termo "família" foi escolhido por denotar tanto uma unidade como um coletivo de elementos os quais possuem singularidades mas também similaridades e inter-relações.
} 
e) Juntamente com a segunda revisão dos dados, o pesquisador escreceu um texto reunindo fragmentos de descrições, caracterizações e reflexões preliminares sobre os aspectos considerados significativos na intervenção. No textọ a intenção não foi discutir exaustivamente cada um dos aspectos, mas sim, explicitar elementos, exemplos e interpretações que poderiam compor o universo argumentativo usado para esclarecer as questões iniciais e ou contribuir para os objetivos da pesquisa.

f) Considerando-se os resultados deste levantamento e das reflexões preliminares foram promovidos diversos tipos de "verificações", junto a 16 pessoas com grande envolvimento no processo: i) entrevistas semi-estruturadas com 7 escolhidos ${ }^{8}$; ii) conversas informais com outras 5 pessoas envolvidas; iii) reunião de avaliação e encaminhamento com 12 cursistas e iv) respostas de 6 cursistas ao questionário final.

g) Em paralelo foram aprofundadas as interpretações sobre estes dados, procurando confirmá-las, confrontá-las e/ou complementá-las com reflexões de outros pesquisadores e autores. Nesta fase ocorreram novas alterações na composição e na denominação das "familias de aspectos significativos" resultando em um novo arranjo, composto por uma familia nucleo e mais quatro outras relacionadas, a saber: a escola; as relações com a realidade e com o conhecimento, as pessoas e as relações interpessoais (conforme representado na figura 2 apresentada na próxima parte da dissertação).

Observar que os múltiplos procedimentos de geração dos dados, em diversas situações, em diferentes momentos e com diferentes envolvidos (inclusive com atuações distintas) e o tratamento destes dados conforme descrito anteriormente possibilitaram a checagem destes dados, configurando uma estratégia denominada "triangulação" conforme Denzin (citado por Lüdke \& André, 1986, p.52).

${ }^{8}$ Os principais critérios para definição dos entrevistados foram: entrevistar pelo menos uma pessoa de cada escola; escolher pessoas que ainda não haviam apresentado uma avaliação mais aprofundada sobre a intervenção; entrevistar tanto cursistas que mudaram como cursistas que não mudaram de escola; promover entrevistas com pessoas específicas: uma com a ATP Aparecida e duas com importantes colaboradores não cursistas um coordenador pedagógico e um professor. 


\section{RESULTADOS E DISCUSSÃO}

\subsection{A INTERVENÇÃO}

Conforme previsto no planejamento, o primeiro aspecto a ser avaliado diz respeito à preparação e à execução da intervenção educacional proposta, ou seja, o curso-oficina de aperfeiçoamento de professores e os seus desdobramentos.

- O curso foi reconhecido e certificado pela Secretaria Estadual da Educação e gerou alguns créditos à carreira dos professores. Observar que esta decisão se deu após várias aulas já ocorridas, portanto não influenciou no interesse de participação nas primeiras aulas.

- Para uma avaliação mais detalhada do curso-oficina é pertinente observar o "Relatório de conclusão do curso" (Fls. 41 e 42 - Apêndice 2) enviado à Secretaria Estadual de Educação e também o parecer desta Secretaria (Apêndice 27).

Especificamente sobre a operacionalização do curso registrou-se poucos problemas e dificuldades. O procedimento, assumido no curso, de diálogo com os participantes e de respeito aos seus pontos de vista, anseios e propostas, possibilitou encaminhamentos imprevistos inicialmente, em especial quanto a alguns temas e abordagens dos projetos propostos. Isto gerou problemas operacionais para o pesquisador/coordenador do curso tais como: necessidade de promoção de diferentes oficinas, maior número de reuniões por equipes para detalhamento dos projetos e ampliação do leque de dados para registro e avaliação.

A avaliação geral é que, conforme esperado, a intervenção possibilitou uma pequena contribuição para a melhoria da qualidade de ensino na rede pública, através de ganhos para os educadores envolvidos tais como: vivência na promoção de projetos de educação 
ambiental; reconhecimento e valorização da produção didática própria; contato com possibilidades de conteúdos, princípios e procedimentos didáticos-pedagógicos relacionadas à educação ambiental; aumento da experiência em atividades coletivas e interdisciplinares; troca de experiências; contato com o método da pesquisa-ação e outros.

Os desdobramentos do curso, ou seja, o planejamento e execução de projetos educacionais em 4 escolas tiveram resultados extremamente diferenciado, Equipe 1: proposta totalmente implantada mantendo continuidade e gerando desdobramentos durante mais de um ano; Equipe 2: proposta parcialmente implantada geração de alguns desdobramento; Equipe 3: proposta totalmente implantada, não gerou desdobramentos; E4 proposta não implantada, entre os motivos está a redução da equipe devido licença médica. Para avaliar a intervenção também podem ser apresentados alguns levantamentos quantitativos:

- A palestra de divulgação recebeu mais de 60 inscrições, número considerado alto inclusive pela Diretoria de Ensino, indicando um grande interesse pelo assunto $\mathrm{e}$ pela proposta. Porém em função de mudança de data e problemas com o telefone da Diretoria de Ensino compareceram à palestra apenas 21 pessoas.

- Os indicadores de participação e permanência no curso foram muito positivos, das 18 pessoas que iniciaram o curso apenas 1 desistiu (após a $1^{\mathrm{a}}$ aula). Este desistente justificou-se apontando a falta de tempo e chegou a declarar seu pesar, posteriormente no transcorrer do curso freqüentou mais uma aula. Além disso 3 pessoas entraram no módulo 2 e permaneceram até o fim; também houve a freqüência eventual de 6 educadores dos quais 3 estiveram presentes em 2 aulas $e$ outros participaram de 1 aula. Observou-se também a participação intensa de pelo menos 10 educadores não cursistas na preparação e aplicação dos projetos nas escolas.

- Quanto a freqüência dos cursistas os números também indicam grande interesse. Apesar da programação prever a dispensa de uma aula para todos durante $\circ 3^{\circ}$ módulo, $60 \%$ dos participantes compareceram a todos as aulas, $25 \%$ faltaram apenas uma vez, $10 \%$ faltaram duas vezes e apenas uma pessoa teve 3 faltas. Sendo que quase metade das faltas tiveram justificativas médica ou profissional. Assim, a maioria dos cursistas tiveram carga horária total (+/- 96 horas) maior que a prevista inicialmente (90 horas)na proposta enviada à Secr. de Educação..

- Todas as etapas propostas inicialmente para o curso foram cumpridas. 


\subsection{ALgumAs RELAÇÕES ENTRE A INTERVENÇÃO E O CONTEXTO DE PESQUISA}

Nos tópicos seguintes são apresentadas avaliações metodológicos e procedimentais em relação a promoção do curso-oficina enquanto estratégia e etapa da pesquisa.

\section{a) Capacidade de gerar dados e informações para o estudo.}

Os objetivos de execução do curso enquanto uma estratégia científica de geração de dados foram alcançados e até superados, na medida que além das informações oriundas do confronto dos pressupostos e hipóteses de trabalho com a realidade, ocorreu a emergência de dados e desdobramentos inesperados. O curso possibilitou a participação ativa de agentes educacionais detentores de várias das questões da pesquisa e portanto interessados em sua resolução. A ampliação de envolvidos na resolução das questões iniciais ampliou a confiabilidade dos dados e possibilitou o aperfeiçoamento das respostas, principalmente no seu caráter mais prático.

\section{b) Efetividade em captar e registrar os dados.}

Neste caso é possível identificar uma certa dificuldade operacional, em função da dinâmica do processo e da enorme carga de situações geradoras de dados e informações. O problema principal foi produzir múltiplos registros (filmar, gravar, fotografar, anotar, ...) simultaneamente à condução do curso-oficina (promoção de palestras, mediação de debates, acompanhamento de oficinas, etc.) ou de seus desdobramentos (promoção de atividades nas escolas, apresentação em eventos, reuniões com autoridades, etc.). Por exemplo, nas situações em que o pesquisador exercia mediação de um debate e desejava registrar o evento, a opção vídeo tornou-se muito difícil, as anotações eram até possíveis mas limitadas e diminuíam a eficiência na atividade de mediação, neste caso a melhor alternativa de registro era a gravação de áudio. A dificuldade tornava-se crítica em casos de falhas técnicas ou operacionais dos equipamentos. Apesar das dificuldades é possível afirmar que o monitoramento da intervenção foi realizado satisfatoriamente, sendo que a quase totalidade de atividades desenvolvidas ou acompanhadas pelo pesquisador possuem pelo menos um tipo de registro. 


\section{c) Possibilidade de gerar respostas e resultados.}

A promoção do curso e o acompanhamento dos projetos, numa situação em que as condições do objeto-processo enfocado eram quase normais, gerou um enorme ganho para os objetivos científicos da pesquisa $O$ resultado foi um amplo conjunto de dados com alta confiabilidade para formulação de respostas às questões iniciais.

\section{d) Os cursistas como pesquisadores}

A proposta inicial da pesquisa previa que os educadores envolvidos formulariam suas respostas a questão chave da pesquisa (Q3). Para tanto foram empreendidas estratégias incentivando-os a incorporarem a questão e para subsidiá-los de conhecimentos e experiências diretas com o assunto, simultaneamente buscou-se criar situações estimulando a reflexão, o posicionamento e a formulação de respostas. Porém esta intenção de envolver os cursistas enquanto pesquisadores-colaboradores não ocorreu conforme esperado inicialmente.

Os cursistas apresentaram dificuldades tanto em aprofundar como em registrar suas reflexões sobre o trabalho educacional em geral e sobre suas práticas e vivências. A expectativa do pesquisador era quanto a apresentação de respostas de mesma natureza que aquelas que ele pretendia formular em seu estudo. Porém esta expectativa não levava em conta que o referencial, os interesses e as condições dos participantes eram bem diferentes. Os participantes eram educadores, agentes da educação preocupados com a demanda profissional cotidiana que exige respostas práticas, enquanto que o pesquisador buscava produzir um trabalho científico avaliando a inserção de um determinado tema neste cotidiano . Neste sentido as respostas dos educadores cursistas tiveram um caráter pragmático e operatório e baixo componente analítico, teórico ou reflexivo. Coube então ao pesquisador procurar dar uma interpretação a tais respostas, o que será feito mais adiante neste texto.

\subsection{DISCUTINDO OS ASPECTOS SIGNIFICATIVOS DA PESQUISA.}

A seguir serão apresentados e discutidos os aspectos significativos da pesquisa, identificados e agrupados conforme explicado no tópico 3.5 e representado na figura 2 a seguir. O que se verifica é uma grande interface e sombreamento entre estes aspectos e mesmo entre as familias. Observar que trata-se de um recurso de apresentação e manipulação dos dados e informações sem pretensão de constituir uma representação da realidade. 


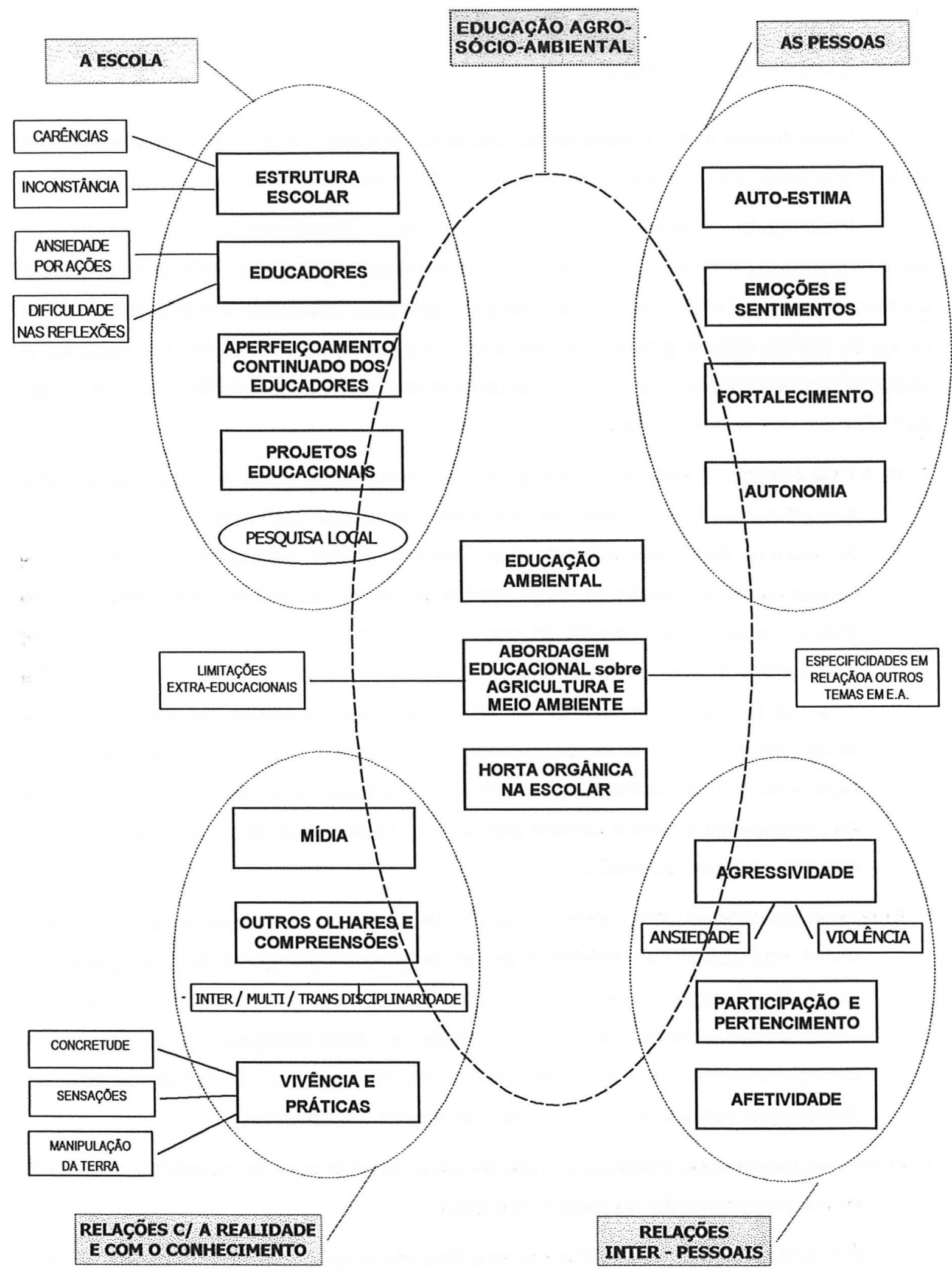

FIGURA 2 - MAPA DOS ASPECTOS SIGNIFICATIVOS PARA A PESQUISA 


\subsubsection{A INSTITUIÇÃO ESCOLAR}

Nesta família foram agrupados os elementos e aspectos intensamente relacionados ao funcionamento e à estrutura da instituição escolar e que se destacaram na pesquisa.

Inicialmente, considerando que os fenômenos educacionais sofrem uma série de determinações a partir de sua inserção social e histórica (Ludke \& André, 1986, p.5), é preciso apontar que o sistema educacional brasileiro está submetido a muitas dificuldades, as quais afetam tanto o grupo estudado como a abordagem do assunto em questão. $\mathrm{A}$ seguir são apresentados três conjuntos de problemas que, no período da pesquisa, atingiram intensamente o sistema escolar:

a) a rede pública de ensino apresenta um panorama institucional instável e ameaçador aos educadores, decorrente de reformas promovidas pelo MEC e pela Secretaria Estadual de Educação incluindo, entre outras medidas: alterações curriculares profundas (como a redução de carga horária de várias disciplinas); municipalização do ensino fundamental; adoção de parâmetros curriculares; progressão continuada; avaliações externas; instituição de escolas específicas para as antigas $1^{\mathrm{a}}$ à $4^{\mathrm{a}}$ e $5^{\mathrm{a}}$ à $8^{a}$ séries e colegial) implicando em alta rotatividade de alunos nas escolas e constantes remanejamentos de educadores. Tais medidas, além de dificultarem o planejamento e a continuidade dos trabalhos, fomentavam nos educadores sentimentos de insegurança quanto a carreira profissional, local de trabalho, conteúdos e procedimentos a serem adotados.

b) no periodo ocorreu uma contenção de investimentos governamentais na área educacional, implicando na inexistência de um programa abrangente de formação continuada de educadores; carência de verbas nas escolas para atividades extraclasse; concentração de alunos por classe; extinção de várias Delegacias de Ensino sobrecarregando o trabalho das remanescentes (transformadas em Diretorias Regionais de Ensino), por sua vez agravando a falta de verbas e de pessoal.

c) falta de perspectiva profissional e até de futuro de vida para os estudantes articulada com a desvalorização da instituição escolar.

É importante notar que muitas observações em relação a instituição escolar e suas diversas dimensões coincidem com as verificadas pelo pesquisador em outras ocasiões e 
por outros pesquisadores em várias partes do estado e do país. Como exemplos podem ser citados: i) a pesquisa recente de Segura (1999) sobre a educação ambiental em escolas públicas na zona leste da cidade de São Paulo por Segura que identifica problemas como falta de verbas e instabilidade institucional; ii) documento do MEC (Brasil, 1999) sobre formação de professores.

\subsubsection{Estrutura escolar}

Em grande parte devido as muitas alterações impostas ao sistema de ensino nos últimos anos, a atual estrutura escolar apresenta uma série de problemas para os educadores tais como:

- Grande carga de trabalho burocrático;

- Multiplicidade de atividades sugeridas pela D.R.E.;

- Atribuição de muitas séries diferentes e diversas salas, implicando em grande carga de preparação de aulas e acompanhamento dos alunos;

- Classes com número muito grande de alunos;

- Pequena carga horária disponível para os educadores planejarem seus trabalhos; e, simultaneamente, em alguns casos o sub-aproveitamento do horário de trabalho pedagógico (HTP) e do horário de trabalho pedagógico coletivo (HTPC), decorrente principalmente da quantidade de trabalho dos professores que obriga-os a usarem o tempo para correção de provas ou preenchimento de planilhas; da existência de apenas um coordenadorpedagógico por período (implicando em uma grande carga de trabalho) e da carência de formação continuada específica para esta função.

Na pesquisa confirmou-se o importantíssimo papel da direção, não só na estrutura administrativa, mas também no funcionamento didático pedagógico da escola, algo já apontado por outros especialistas como Segura (1999). Durante o trabalho constatou-se 3 perfis de direção que, num exercício de síntese, podem ser assim caracterizados:

Perfil X: diretora e vice trabalhando em equipe, presentes, acessiveis, prestativos, delegadores de poder aos coordenadores pedagógicos, estimuladores das iniciativas dos educadores, valorizando a autonomia dos educandos; acompanhando e quando necessário atuando em favor dos projetos. 
Perfil Y: diretora extremamente centralizadora de poder e informação; sempre presente; acessibilidade e prestatividade variável conforme o "humor"; desestimuladora das iniciativas dos educadores; desvalorizando a autonomia de alunos e professores em favor das regras e da autoridade; monitorando o andamento do projeto dos professores mas, geralmente, desestimulando e desqualificando a iniciativa.

Perfil Z: direção apática, pouco presente, distante da iniciativa dos educadores, apoio discreto ao projeto.

A existência de direções autoritárias e centralizadoras em escolas constitui-se em uma situação totalmente divergente do que reza importantes orientações nacionais como a Lei de Diretrizes e Bases da Educação e documentos internacionais como o Relatório para a UNESCO da Comissão Internacional sobre Educação para o século XXI. Caso as instâncias responsáveis realmente assumissem o recomendado neste último relatório citado, ou seja: "fazer da escola um modelo de prática democrática" (Delors, 2000, p.61) processos extremamente educativos para toda a comunidade escolar poderiam ser implementados como: constituição de efetivos conselhos de escolas e eleição direta de diretores das unidades escolares (escolhidos entre educadores capacitados para tal função).

\subsubsection{Os educadores}

O intenso contato do pesquisador com o grupo enfocado permitiu constatar que os educadores encontravam-se profissionalmente desprestigiados; emocionalmente debilitados; submetidos a uma carga de trabalho excessiva devido ao grande número de aulas, de classes e de alunos por classe (salas com mais de 45 alunos); assustados com a indisciplina e até violência física dos educandos; desorientados pelas alterações no sistema educacional; confrontando-se com demandas (sociais, econômicas e afetivas) dos estudantes que extrapolam o âmbito educacional tradicional.

Obviamente o grupo enfocado apresentava características e situações específicas em relação ao quadro da educação pública em geral, destacando-se o alto grau de participação e envolvimento em intervenções educativas, o que é marcante entre os educadores de Ibiúna, conforme depoimentos de três A.T.P.s e de um Supervisor de Ensino da D.R.E. Também verificou-se um grande interesse específico na proposta de curso apresentada, motivado principalmente pelos procedimentos (preparação conjunta de "produtos didáti- 
$\cos ^{\prime \prime}$ ), pelo assunto (agricultura) e pelo enfoque (ambiental).

Desde os contatos iniciais destacou-se a grande diversidade entre os educadorescursistas quanto à qualidade da formação, à experiência, à expectativa profissional, aos interesses e aos questionamentos pessoais. Esta diversidade pode ser constatada em vários registros tais como os desenhos e transcrições das falas sobre as preocupações ambientais (apêndice 6) ou a transcrição da avaliação realizada no Encontro 3 (apêndice 11).

Uma característica marcante observada entre os educadores-cursistas foi a dificuldade individual de realizar reflexões sobre o seu papel, a sua situação de educador e outros assuntos que Ihes diziam diretamente respeito, por exemplo: Quando responderam à questão: "O que me faz um(a) prof.(a) preocupado(a) com a questão ambiental?" (apêndice 6), a maioria tratou de temas ambientais e pouquíssimos referiram-se ao fato de serem professores. Quase todas as resenhas de textos produzidas pelos cursistas restringiram-se a destacar tópicos dos textos, muitas vezes reproduzindo trechos. Pouquíssimos cursistas procuraram dialogar com os textos.

Mas, quando ocorreram oportunidades coletivas para os educadores exporem suas experiências relacionadas ao cotidiano escolar observou-se o aprofundamento e o enriquecimento das reflexões, foi isto que ocorreu no exemplo citado acima, após as apresentações individuais, iniciou-se um debate espontâneo que enfocou prioritariamente a função do educador diante das questões ambientais (apêndice 6). Assim, apesar da maioria dos cursistas apresentar dificuldade de aprofundamento teórico ou reflexivo, a existência de alguns mais experientes ou que já traziam questionamentos possibilitou o enriquecimento dos debates. Isto permitiu intensas e diversificadas trocas, contribuições e ganhos entre os cursistas.

Desde o início da intervenção, a maioria dos educadores-cursistas expressava que a educação deveria ir além da disponibilização e "armazenamento" de informações. Uma frase proposta por uma professora e depois adotada em várias ocasiões por outros cursistas indica o tipo de preocupação dos educadores: "- De que adianta nota dez na escola e zero na vida?" Provavelmente vinculado à preocupação anterior, a quase totalidade dos participantes apresentava uma incisiva demanda quanto a técnicas pedagógicas, procedimentos e instrumentos educacionais voltados à ações. Inicialmente o pesquisador levantou a seguinte hipótese: "A preocupação com os procedimentos e com as ações associa-se ao comportamento de valorização do agir e do fazer conjugado a um desprezo com a reflexão 
e, muito provavelmente, decorre do excesso de idealizações e teorizações livrescas característica da Escola atual, inclusive daquelas que formam professores". Outros autores já apontaram esta questão. Segura fala sobre o "pragmatismo que reina na esfera pedagógica, onde a busca da novidade muitas vezes assola a reflexão e a coerência entre objetivos e estratégias" (1999, p.53). Sobre esta preocupação procedimental entre os educadores, Gadotti apresenta uma interpretação interessante: "A concepção tecnoburocrática leva os educadores a pensarem que o problema da educação é saber como é preciso fazer para ensinar e não como é preciso ser para ensinar" (citado por Peña, 1997, p.62).

As observações e reflexões durante a pesquisa não negaram as interpretações anteriores, mas indicaram a necessidade de considerar a complexidade do fenômeno. Os educadores são os "agentes" da educação, foram formados e são cobrados pela sociedade e pela instituição escolar para ensinar. Além disso a maioria é responsável um grande número de turmas e séries diferentes o que requer um exaustivo trabalho de preparação de aulas e outras demandas burocráticas. Considerando-se estes pontos torna-se mais compreensível que suas preocupações sejam quanto à ações de ensino.

Por sua vez, o pesquisador que se inseriu no processo exatamente para aperfeiçoar sua reflexão, apresenta uma ansiedade, uma disponibilidade e uma possibilidade (por dever da atividade) de realizar reflexões maiores que os demais participantes. Além disso é preciso atentar que a crítica ao excesso ou ao exclusivismo de preocupações procedimentais só tem sentido a partir de determinadas concepções de educação, porém no modelo tecnicista e de "transmissão de conhecimentos" é quase desnecessário a reflexão do educador.

Uma observação importante sobre os educadores envolvidos foi feita pelo pesquisador após 4 meses e 8 ocasiões de aulas e diversas reuniões e atividades com a turma:

"Creio que há um importante elemento positivo e facilitador do processo educacional com esta turma: A grande maioria dos participantes se apresenta aberta, reconhecendo e por vezes explicitando suas dificuldades e fraquezas, disposta e interessada em incorporar novos conhecimentos, valores, atitudes; desguamecida diante de um sujeito estranho ao universo escolar local" (Pesquisador - Caderno de campo e de reflexões - 30/06/1999).

\subsubsection{Aperfeiçoamento continuado de educadores}

O desenrolar do trabalho possibilitou uma série de observações e reflexões sobre capacitação, atualização e aperfeiçoamento de educadores em serviço. Um dos primeiros pontos que se destaca é quanto a falta de políticas públicas consistentes e duradouras 
voltadas ao aperfeiçoamento continuado de professores. O que pode ser exemplificado pela falta de verbas nas escolas e na D.R.E. para custear programas ou atividades de capacitação de professores.

Um documento produzido pelo Ministério da Educação visando "contribuir para a sistematização do debate nacional sobre a formação de professores" (BRASIL, 1999, p.10), apresenta uma caracterização crítica com 25 aspectos do atual modelo de formação inicial e continuada de educadores, deste total pelo menos 12 foram, de alguma forma, observados na presente pesquisa, principalmente através das avaliações e comparações em relação a cursos anteriores feitas pelos próprios cursistas:

- "Ignoram-se as condições reais e os pontos de partida dos professores - seus interesses, motivações, necessidades, conhecimentos prévios, experiências e opiniões";

- " a concepção é autoritária, cabendo ao professor um papel passivo";

- "o enfoque é instrumental (...) destina-se a preparar o professor para ser um aplicador e um técnico";

- "não há articulação entre conteúdo e método, entre saber geral e saber pedagógico";

- "a educação é tratada como atividade formal e rígida, desconsiderando-se a importância que tem a informalidade, o vínculo afetivo, a comunicação, o jogo, o riso ";

- "a concepção de base é acadêmica e teórica, centrada no texto escrito, desprezando-se a prática como importante fonte de conteúdos da formação";

- "a transmissão de informação é o centro do processo de ensino e aprendizagem";

- "não há coerência entre o modelo de formação (pelo qual os professores aprendem) e o modelo de ensino e aprendizagem que é conteúdo de sua formação";

- "cada nova política, projeto ou programa parte da 'estaca zero', desconsiderando a experiência e o conhecimento já acumulados";

- "organiza-se para professores individualmente, e não para a equipe pedagógica da escola ou a instituição escolar como um todo";

- "realiza-se fora do local de trabalho, e não na escola, lugar privilegiado de formação em serviço";

- "utiliza dispositivos de motivação 'externa'- pontuação, progressão na carreira, certificados...que, sem dúvida são importantes, mas não podem 'estar no lugar' do compromisso, pessoal e institucional." (BRASIL, 1999, p.42 e seg.)

Especificamente sobre a intervenção educacional promovida, diversos indicadores e avaliações dos cursistas, do coordenador pedagógico Peri e da assistente técnicopedagógica da Diretoria de Ensino apontam que houve sucesso em seus objetivos. O pesquisador interpreta que os principais possibilitadores deste sucesso foram:

- Uma predisposição de muitos educadores da região para o envolvimento em iniciativas propostas. 
- A participação voluntária dos cursistas-educadores decorrente de interesses pessoais e não devido a determinação superior.

- A apresentação prévia do plano do curso, através da palestra de divulgação, permitiu um primeiro contato dos potenciais interessados com o propositor e sua proposta.

- A configuração do curso no formato "oficina" incluindo o planejamento e a produção didática pelos próprios participantes no decorrer do processo, o que convergia com seus anseios e necessidades.

- A participação de coordenadores pedagógicos das escolas no curso e ou nos seus desdobramentos.

- A programação com duração de médio prazo.

- A opção por trabalhar com grupos multidisciplinares de educadores da mesma escola, contribuindo também para o sucesso dos projetos empreendidos pelos cursistas.

- O fato do curso ocorrer nas escolas e sempre procurar articular-se com o cotidiano e com os atores do ambiente escolar. Nóvoa (citado por Candau, 1996, p.144) é um dos especialistas que valoriza os programas de formação de educadores que ocorrem nas escolas e que estruturam-se "em torno de problemas e de projetos de ação e não em torno de conteúdos acadêmicos".

- A apresentação dos princípios ambientalistas e de educação ambiental e o encaminhamento baseado em tais princípios.

- O emprego de procedimentos diversificados destacado-se: palestras; debates; pesquisas locais; vivências; visitas a estabelecimentos agrícolas de produção orgânica; leituras prévias; planejamento participativo; relatos de experiências; produção coletiva de textos, painéis e projetos educacionais; arte-educação e múltiplas avaliações.

- A promoção de pesquisas sobre temas de escala local e ou relacionados ao cotidiano, mesmo sendo pouco usada no curso constituiu-se em um procedimento eficiente para estimular o interesse, aumentar a participação e valorizar a produção de conhecimentos dos cursistas sobre a comunidade e a realidade local. Vários cursistas expressaram satisfação em realizar a atividade, tanto pelo acesso a informações locais como pela percepção do tipo de tratamento oferecido pelas pessoas contatadas nestas ocasiões. Além disso a execução das pesquisas de campo proporcionou aos cursistas contatos com autoridades locais e representantes de instituições e de empresas, muitos dos quais se tornaram parceiros nos projetos desenvolvidos posteri- 
ormente. Neste aspecto as observações convergiram para as considerações de Pedro Demo que em várias obras (Demo, 1994, 1997 e 1998) destaca a importância da pesquisa na educação escolar.

- A produção de textos coletivos, apesar das dificuldades operacionais e do pouco uso, foi outro procedimento educacionalmente rico, contribuindo para dar maior concretude aos trabalhos, através da geração de "produtos" como: "Nosso diagnóstico geral sobre agricultura" (Apêndice 8) e "Nossas considerações sobre educação ambiental" (Apêndice 13); resgatar e valorizar os conhecimentos e opiniões do grupo; auxiliar a construção e consolidação de novos conhecimentos dos participantes. Este procedimento poderia ter sido utilizado mais vezes e com menor participação do coordenador do curso, eventualmente através da delegação de pessoas responsáveis, porém sempre esbarrou na falta de tempo e na insegurança dos participantes.

- A construção coletiva de propostas de projetos e a sua implementação.

- A assessoria individualizada a cada equipe escolar no planejamento, no desenrolar e na avaliação dos projetos, fortaleceu e proporcionou aos educadores-cursistas maior segurança na condução da iniciativa.

- A promoção das palestras-oficinas com diferentes especialistas. Um dos pontos mais positivos do curso que além de contribuir com informações e técnicas inovadoras e criativas, ofereceu a oportunidade dos cursistas manterem contato com perspectivas e filosofias, posturas e procedimentos de vida e de educação distintos porém convergentes e até então desconhecidos. Em geral os palestrantes foram tomados como exemplos de discurso e prática ambientalista, ou seja suas posturas constituíram-se em "conteúdos pilares" do curso. As avaliações, que muitas vezes aconteceram em encontros posteriores, possibilitaram consolidar os conhecimentos e enriquecer as experiências com os palestrantes. Outro ponto positivo foi a constituição de laços entre os cursistas e os palestrantes.

Porém, durante uma avaliação sobre a capacidade de comunicação de um determinado palestrante, a manifestação de uma cursista remeteu a uma faceta que necessita ser levada em conta em cursos deste tipo, disse ela:

“- A gente não consegue ver o peso da palavra dele nas aulas que a gente dá. Aí que a gente fica: 'puxa vida' ele cativa todo mundo e os meus 45 eu não consigo cativar, eu fico triste" (apêndice 18 / parágrafo 82). 
Entre as falhas ou deficiências do curso identificadas pelo pesquisador estão: a) a não execução, no âmbito do curso, de uma avaliação em profundidade quanto aos aspectos negativos e deficiências dos projetos; b) deficiências nos procedimentos visando a consolidação de aprendizagens proporcionadas no processo; c) a falta de uma autoavaliação de cada participante sobre sua atuação. Parte destas demandas estavam previstas para o encontro de encerramento, mas este assumiu o caráter de apresentação para um público amplo estimulando o enfoque nos pontos positivos.

Posteriormente outras tentativas de avaliação foram empreendidas mas não se concretizaram, seja a solicitação de textos avaliativos (Apêndice 29) ou a promoção de reuniões gerais com a turma. Apenas no caso da Escola 2 ocorreu uma reunião, com quase todos da equipe, em que se discutiu o desenrolar do projeto. O pesquisador considera que 0 curso necessitava um período maior a fim de promover a avaliação dos projetos, o aprofundamento de reflexões sobre o processo e o exercício dos educadores-cursistas produzirem projetos juntamente com seus alunos.

Algumas limitações observadas na pesquisa quanto a processos de aperfeiçoamento continuado de educadores no âmbito das escolas foram também apontadas em um documento do Ministério da Educação (BRASIL, 1999, p.47): "ou não há tempo previsto na jornada de trabalho que permita ações sistematizadas ou, quando há, muitas vezes o coordenador pedagógico não tem uma formação adequada para ser formador de professores e nem recebe assessoria para realizar esse tipo de trabalho".

Segundo vários indicadores, foram atingidos os objetivos de "capacitação" sobre as relações agro-ambientais, o ambientalismo e a educação ambiental. Porém, ao final do processo consolidou-se a percepção daquilo que talvez seja o principal fator limitante em relação aos objetivos de estimular o questionamento da agricultura convencional e a valorização de propostas sustentáveis, através da educação. Percebeu-se, entre os educadores envolvidos, uma grande deficiência de reflexões sobre o sentido e os objetivos do trabalho educacional como um todo. O que remete seguinte questão:

No contexto de um processo de aperfeiçoamento de educadores que se pretendia especifico no tratamento de um assunto (as questões agro-ambientais), como trabalhar a deficiência de formação e de reflexão dos envolvidos quanto a educação? 


\subsubsection{Projetos nas escolas}

\subsection{O processo}

Desde o início a possibilidade de conceberem seus próprios projetos foi avaliada, por vários envolvidos, como um ponto muito positivo na intervenção. Ocorre que em geral os professores atuam apenas como executores, não participando da concepção e planejamento dos projetos educacionais. Para Ivani Fazenda um projeto interdisciplinar não deve ser imposto, mas sim surgir de um "ato de vontade" em que o "envolvimento" é um aspecto fundamental (Fazenda, 1997, p.17).

O planejamento das propostas foi um momento delicado e fundamental, tanto para os cursistas quanto para a pesquisa, deixando evidente a importância e a necessidade de respeitar a "velocidade" do grupo. A construção das propostas em cada escola constituiu-se em um processo de articulação de interesses, de esclarecimento sobre formulação de projetos, de consolidação de conceitos em E.A. e de exercício de criatividade. Nesta etapa de planejamento foram muito importantes para a formatação de propostas implementáveis o conjunto de procedimentos conduzidos pelo Prof. Sorrentino e o acompanhamento do coordenador durante o detalhamento das propostas.

A execução de oficinas práticas, vivências e o contato direto com iniciativas parecidas, ocorridas durante o planejamento possibilitou o encorajamento e até a incorporação de habilidades específicas para a promoção dos projetos. Exemplo 1: educadores cujo projeto incluía a montagem de uma horta mostraram-se mais a vontade, após realizarem estágio em um estabelecimento agrícola. Exemplo 2: educadores que pretendiam organizar um viveiro de mudas de árvores demonstraram menor receio diante da empreitada após visitarem o viveiro de uma grande empresa.

Segundo relatos dos próprios educadores, eles acumulam várias experiências de interrupção de iniciativas, o que gera um grande sentimento de frustração. Este histórico estimulou duas preocupações durante o planejamento: a) promover integralmente aquilo que fosse proposto e b) garantir a continuidade dos projetos ou preparar caminho para novas propostas. Assim as Equipes 1 e 3 conceberam seus projetos como etapa inicial de um processo que se daria através da continuidade ou desdobramentos desta primeira iniciativa. 


\subsection{Resultados}

As 4 propostas formuladas superaram a expectativa inicial na medida que tiveram o formato de projetos envolvendo diversas disciplinas e incluíram atuações extraclasse. Deste total, dois projetos foram integralmente promovidos (equipes E1 e E3), um foi em grande parte implementado (equipe E2) e um não foi encaminhado (equipe E4). A equipe E4 era a mais "frágil", composta por apenas dois membros, sendo que um ingressou apenas no $2^{\circ}$ módulo e o outro licenciou-se um mês durante o período previsto para a implementação da proposta.

A quase totalidade dos educadores envolvidos externaram avaliações positivas em relação à promoção dos projetos, os quais foram considerados entre outras coisas, como um fato novo capaz de estimular o interesse e motivar a participação dos educandos. Este tipo de interesse foi observado pelo pesquisador em um depoimento espontâneo de um aluno ao encontrar sua mãe:

- "Mãe, a minha escola está diferente, tem uma horta lá, hoje a professora levou a gente p'ra ver, foi legal! " (Aluno M, 13 anos, Escola 1, conforme Caderno de campo).

Em algumas situações os projetos parecem gerar sinergias e realimentações positivas, configurando um ciclo que pode ser descrito do seguinte modo:

o(s) educador(es) empreende(m) uma iniciativa ligada a um projeto, isto aumenta o interesse dos educandos,

a percepção do aumento de interesse dos educandos gera maior empolgação no(s) educador(es),

$\mathrm{o}(\mathrm{s})$ qual(is) procura(m) aperfeiçoar suas iniciativas e reiniciam o ciclo.

Tal processo foi percebido claramente no caso da Escola 2. Após visitarem um Parque Estadual os alunos passaram a cobrar a implementação do projeto e os educadores aumentaram suas preocupações com o mesmo.

Tanto no curso como nos projetos implementados nas escolas, houve uma relativa facilidade de obtenção de adesões de participantes e parcerias com instituições públicas e mesmo com empresas privadas. Por exemplo: apesar das dificuldades e sobrecarga de trabalho todos os projetos propostos receberam apoio e participação de educadores não cursistas. O pesquisador considera isto uma decorrência do caráter "simpático" e pouco ameaçador ao "status quo" que as iniciativas educacionais envolvendo a temática ambiental apresentavam (pelo menos a primeira vista). 
A existência de equipes multidisciplinares por escola (consolidadas durante o curso) foi um fator muito importante para o efetivo desenvolvimento dos projetos. Dois fatos ilustram tal avaliação: a) A equipe da Escola 4 iniciou o curso com apenas um representante $e$ posteriormente teve inclusão de mais um educador mas não conseguiu implementar a proposta; b) A equipe da Escola 2 composta por 10 educadores apesar de diversos obstáculos que thes foram impostos conseguiu encaminhar boa parte da proposta inicial, além de outros atividades propostas no transcorrer dos trabalhos.

As apresentações dos projetos em diversos eventos além de divulgar e valorizar os projetos, demonstrou a viabilidade de parcerias, proporcionou novos contatos, possibilitou a divulgação dos assuntos tratados nos projetos, despertou interesse em outros educadores, possibilitou identificar o interesse de participação dos estudantes em eventos fora da escola.

\subsection{Limitações e dificuldades}

Uma das maiores limitações envolvendo a promoção dos projetos foi a falta de estruturas e condições institucionais prevendo tempo aos educadores-cursistas para se dedicarem a iniciativa. Entre as conseqüências desta falta de tempo está a não realização de revisões preliminares dos textos dos projetos.

Um aspecto que se mostrou tão importante quanto difícil foi possibilitar e garantir a participação de todos na formulação da proposta da respectiva equipe.

Outra observação importante foi a grande dificuldade, de todos os educadores envolvidos, em detalhar os seus projetos, incluindo dois aspectos interligados:

i) um grande enfoque nas ações a serem desenvolvidas e a preocupação com as técnicas e procedimentos associados a estas ações;

ii) uma grande dificuldade de explicitar os objetivos educacionais das propostas ${ }^{9}$.

Apesar do empenho do educador para que fosse formulado uma proposta escrita para cada projeto, em geral observou-se a desconsideração deste textos, enquanto referên-

\footnotetext{
${ }^{9}$ Segundo várias fontes, a dificuldade em formular projetos educacionais não é uma característica especifica do grupo enfocado. O problema foi apontada pela A.T.P. Aparecida em relação a outros educadores, verificada em diversos projetos de E.A. ocorridos no estado de São Paulo conforme avaliação da educadora Irene Sabiá (Secretaria Estadual de Meio Ambiente - SP em palestra no Seminário sobre Educação Ambiental - Faculdade de Saúde Pública 08/11/2000.) e constatado pelo pesquisador em diferentes grupos de educadores (por exemplo entre participantes de um curso de pós-graduação envolvendo formação de professores na Faculdade de Educação-USP.)
} 
cia para os projetos. Algo observado em alguns projetos foi que, em função da deficiência nas anotações durante as reuniões de detalhamento das propostas e das dificuldades de verbalização e redação, as versões escritas apresentaram várias inserções pessoais dos redatores e a desconsideração ou ausência de conceitos, propostas e decisões definidas nas reuniőes.

As quatro propostas de projetos educacionais incluíram atuações práticas, o que o pesquisador considerou positivo. Porém durante o transcorrer dos trabalhos constatou-se o grande apego a estas práticas e um desprezo ao componente educacional do processo. Em estudo recente a pesquisadora Denise Segura $(1999$, p.88) identificou semelhante tendência entre diversos educadores da região leste da cidade de São Paulo.

No caso de "projetos em educação ambiental" há uma soma de vetores estimulando as ações práticas, de um lado a experiência dos professores em projetos educacionais e de outro a influência de algumas concepções reducionistas sobre E.A., apontadas por Figueiredo \& Silva, em que a E.A. é considerada "como fazer algumas atividades práticas" (1997, p.94).

Um outro aspecto Associado ao anseio por ações e à deficiência dos envolvidos em relação a dimensão educacional foi observado. Em uma reunião com diversos ex-cursistas várias manifestações apontaram que a grande maioria dos envolvidos, assumiram os projetos mais como cursistas do que como educadores autores de iniciativas (projetos). Os participantes não ofereceram respostas de caráter majoritariamente educacional, deixando em segundo plano suas atuações como educadores, para vivenciarem a atuação de enfrentadores de problemas ambientais. É como se os educadores envolvidos nos projetos não respondessem àquela questão inicial, mas sim a uma outra, parecida :

"O que as equipes de pessoas atuantes numa mesma escola podem fazer diante das questões envolvendo as relações entre agricultura e meio ambiente?

Algumas interpretações para as observações anteriores pode ser consideradas:

- Faltava vivência pessoal no acontecer de projetos.

- Faltava reflexões e acúmulo teórico sobre objetivos e atuação educacional.

- Faltava experiência na condução de projetos educacionais.

- Faltava acúmulo teórico e experiência sobre a relação: educação e meio ambiente.

Outros questionamentos emergem 
- O pesquisador não teve estratégia suficiente para apresentar a questão inicial e/ou para motivar, subsidiar e orientar a formulação de respostas?

- Os participantes não apresentavam as condições necessárias para formularem as respostas?

- Os participantes não tinham como prioridade responder a questão apresentada?

Quando, por conta de dificuldades materiais e institucionais, os projetos passaram a sofrer atrasos e impedimentos, alguns alunos sinalizaram o interesse nas propostas e realizaram cobranças junto aos seus professores, provocando nestes dois tipos de reação:. a) sentimentos de impotência, ansiedade, desconforto, angústia, frustração, ... b) estímulo para a execução e fortalecimento das intenções dos agentes. Estas foram as reações dos educadores da Escola 2 que impedidos de realizarem importantes etapas da proposta inicial, declararam avaliações que variavam de uma postura negativista do tipo:

-“Estou desanimado, enquanto não houver o plantio de árvores o projeto não aconteceu."

-“Tanta festa mas não aconteceu na realidade."

Até avaliações otimistas como:

- "Lançamos uma semente, marcamos os alunos que participaram".

- "Valeu a pena pois nos aproximou das questões ambientais"

No caso da Equipe E2, as duas fases consideradas fundamentais no projeto (campanha arborização junto a comunidade e acompanhamento de um viveiro de mudas ) foram impedidas por dois aspectos: a) falta de interesse da direção da escola na implementação total do projeto; b) falta de verbas do principal parceiro (Prefeitura Municipal) para a montagem do viveiro naquele ano. No caso do segundo problema as autoridades municipais esclareceram que havia necessidade de destinação orçamentária prévia, neste sentido o Prefeito Municipal comunicou, durante o Evento de Encerramento do curso (nov/99), que tal verba estava prevista no orçamento do ano seguinte.

Os problemas na promoção dos projetos e as reações dos educadores remete a algumas interrogações:

Como estimular os sonhos, a criatividade e a empolgação dos educandos e articulálos com as limitações e dificuldades. Ou em outras palavras: Como conduzir um processo que auxilie os educandos a produzirem propostas viáveis e articuladas com suas utopias?

Como o educador pode evitar, ou pelo menos contribuir para a redução do senti- 
mento de frustração que eventualmente ocorrerá, entre os educandos, com o surgimento de problemas e limitações impostas ao sonho?

Este problema é mais expressivo na medida que os sonhos são concebidos e ou traduzidos na forma de produtos ou ações e não enquanto processo. No transcorrer dos projetos o pesquisador adotou algumas estratégias para valorizar os passos e produções intermediárias. Posteriormente refletindo sobre esta questão o pesquisador identificou a necessidade de estimular o entendimento do planejamento e da execução da proposta como etapas da caminhada rumo ao sonho. Trata-se de resgatar a noção de processo educacional e articular com o conceito de prioridade e metas.

Segundo a avaliação de alguns educadores-cursistas: "os projetos foram dos professores e não exatamente dos alunos" por isso eles apontam que "o próximo passo seria: os alunos pensarem e desenvolverem seus projetos". O pesquisador concorda com esta avaliação mas apresenta duas preocupações:

a) O número excessivo de alunos por classe provavelmente dificultará a atuação dos professores no estímulo e acompanhamento dos projetos dos estudantes.

b) A dificuldade dos professores em formular as propostas dos projetos sinaliza a tendência de que eles terão dificuldades para auxiliar os educandos a construírem suas próprias propostas.

\subsubsection{AS PESSOAS}

Castoriadis lembra que a subjetividade "é uma virtualidade de todo ser humano, não uma fatalidade" (citado por Burnham, 1998, p.48), mas em geral, nas escolas a complexa interioridade das pessoas é esquecida, não havendo espaços de manifestação e valorização do essencial humano (emoções, sentimentos, valores, etc.). O que se percebe é que "para a escola e para os meios informativos é irrelevante o modo como cada pessoa está ou não está se realizando como ser humano (Gutiérrez e Prado, 1999, p.88). A desconsideração em relação à subjetividade torna-se crítica no caso dos pré-adolescentes e adolescentes que vivem, exatamente, uma fase de consolidação de dimensões pessoais como os valores e a personalidade.

A estrutura escolar reduz as pessoas a funções e papeis. Em grande parte, isto deve-se a um ideal tecnicista, estreitamente relacionado ao paradigma científico da modernidade, que impera na escola. Os educadores oprimidos pela tecno-burocracia e seus 
controles (direção, planilhas, normas, parâmetros) e pelos excessos de aulas e de alunos por sala, em geral assumem seus papéis de professores (ensinar ou transmitir conhecimentos). Neste contexto, o conteúdo torna-se referencial exclusivo, deixa de ser meio e torna-se fim em si, enquanto que outros atributos e inteligências dos educandos são renegados. A tendência nas escolas é o aluno ser negado em seu pensar, sentir, imaginar, decidir e agir, a que Barbosa denomina "pedagogia da desautorização" (1998a, p.7). Geralmente, este processo de desqualificação e negação da autoprodução do educando implica em duas conseqüências: i) a redução da auto-estima dos estudante; ii) a recusa em assumirem o papel de alunos, principalmente no caso dos pré-adolescentes e adolescentes, implicando no desinteresse do estudante pela escola.

Várias situações relacionadas ou desdobradas dos projetos dos educadorescursistas permitiram a valorização dos elementos pessoais e interiores dos envolvidos proporcionando resultados positivos para os educandos, para os educadores e para o processo educativo, conforme indicam os relatos durante o $15^{\circ}$ Encontro (apêndice 2).

\subsubsection{Emoções e sentimentos}

Em um processo educacional que visa provocar tomadas de posição e mudanças de comportamentos torna-se necessário levar em conta o que diz Goleman: "a chave para uma tomada de decisão mais sábia é em suma: estar mais sintonizado com nossos sentimentos" (citado por Gutierrez e Prado, 1999, p.115). Na mesma linha de argumentação Maturana escreve: "Não é a razão o que nos leva à ação e sim a emoção" (citado por Gutierrez e Prado, 1999, p.114).

É preciso considerar conforme lembrado por Barbier que o "fenômeno emocional aciona não apenas sensações, mas também dimensões cognitivas, imaginativas e intuitivas do ser humano", pois "reagimos com tudo o que somos" (1998, p.179). Gutiérrez e Prado (1999) defendem a importância da emoção, dos sentimentos, das vivências subjetivas, da intuição e de outros aspectos tanto para envolver os educandos no processo pedagógico, como para alcançar os objetivos desse processo, na medida que: "Os sentimentos, como motivadores e impulsionadores, nos colocam - muito melhor que a razão - na pista para conhecer o ser humano, para significá-lo e para dar significado a si mesmo" (1999, p.68).

Barbosa em um artigo que trata da "formação em profundidade" fala sobre a necessidade de "caminhar em direção à maturidade psico-afetiva-cognitiva" do educador (1998b, p.77). É uma pequena contribuição neste sentido que se depreende das avaliações dos 
educadores envolvidos, os quais constantemente ressaltaram como positivo o fato do curso trabalhar dimensões além do cognitivo, incluindo o emocional e o afetivo (por exemplo $6^{\circ}$ Encontro, Apêndice 12).

Entre as observações mais importantes deste trabalho estão os impactos sobre as emoções e sobre o comportamento dos participantes (educadores, educandos e outros membros da comunidade escolar) diretamente envolvidos no projeto Horta Orgânica, conforme relatado durante o Encontro de Encerramento (Apêndice 21) e comentado no item A Horta Orgânica na Escola.

Uma questão relacionada às expectativas pessoais que precisou ser enfrentada no transcorrer da intervenção foi quanto às frustrações. Destacaram-se três situações: a)Frustração de alguns cursistas diante das expectativas induzidas pelo coordenador sobre a performance de determinados palestrantes (ex.: Apêndice 18 / parágrafos 36 e 42); b)frustração durante o planejamento dos projetos devido a constatação das limitações da equipe e da estrutura escolar, após uma fase de euforia decorrente do estímulo para "sonharem" seus projetos; c) frustração pelo não alcance dos objetivos dos projetos.

\subsubsection{Auto-estima}

Várias procedimentos, ocorrências e resultados afetaram de modo positivo a autoestima individual e coletiva educadores-cursistas:

- O fortalecimento e em outros casos a descoberta de capacidades individuais e coletiva de promover iniciativas e atividades novas, criativas e geralmente valorizadas pelos seus alunos.

- A promoção de pesquisas junto a autoridades e funcionários de órgãos públicos possibilitou aos cursistas perceberem a valorização e o reconhecimento que ainda há em relação aos educadores.

- A valorização das produções executadas durante o curso como diagnósticos e textos coletivos gerou manifestações de orgulho e sinais de aumento de autoestima em alguns participantes. Além das avaliações do curso, um outro momento em que foi possivel perceber a valorização conferida aos textos coletivos foi durante um evento na Escola 2, quando um representante da Polícia Florestal, interessou-se pelo texto sobre educação ambiental produzido pela turma. 
- A ampliação de repertórios aumentando a segurança nas abordagens educacionais.

- As participações e apresentações dos projetos em eventos dentro e fora das escolas.

- Auto-avaliações periódicas forçaram os participantes a refletirem, perceberem, acompanharem e expressarem-se quanto aos seus próprios avanços, potencialidades e limitações.

- A disposição, da quase totalidade dos participantes, para enfrentar as dificuldades dos projetos, parece associada a um desejo de superar limites e de alimentar a auto-estima.

Os educadores que promoveram o Projeto Horta Orgânica identificaram várias demonstrações de valorização e aumento da auto-estima dos estudantes agricultores ou filhos de agricultores e seus parentes:

a) muitos alunos que geralmente apresentavam um comportamento de inferioridade $e$ ou de ocultamento da condição de agricultores ou filhos de agricultores, assumiram suas atividades agrícolas e adotaram uma postura mais expansiva em sala de aula;

b) alguns agricultores pais de alunos ao saberem da montagem da horta na escola, passaram a enviar materiais como mudas e adubo orgânico. Outros, em conversas com os alunos ou com os educadores, fizeram menção favorável ao projeto;

c) alguns alunos envolvidos diretamente no projeto assumiram uma postura de orgulho pelo trabalho desenvolvido e demonstraram iniciativa e autonomia a partir da incorporação do repertório de valorização da agricultura orgânica. A melhor representação disto está na fala da aluna Vitória (geralmente tímida segundo seus professores):

"Foi uma grande experiência para gente, (...) eu praticamente já sabia lidar com estas coisas por causa dos meus pais, mas os meus colegas puderam aprender mais sobre o nosso projeto ... horta orgânica. E neste periodo, é bom que a gente está mostrando p'ra todos que a gente pode continuar, e que de uma certa forma eles também podem fazer isto e não é difícil basta você querer. Mas eu sei também que o mundo lá fora está cheio de gente que não reconhece isto. Mas este mundo vai rolar. O importante é que o mundo agradece, a quem faz o melhor para ele, amanhã ... e depois aproveita os resultado com o passar do tempo. Foi realmente maravilhoso estar trabalhando lá, a gente se orgulha vai lá e diz: nós conseguimos, nós fez; acho que não tem coisa melhor, eu mesmo ... foi super dez ..." (Apêndice 21). 
Mesmo os cursistas que não se envolveram no projeto de horta orgânica relataram situações nas quais o tema da agricultura orgânica surgiu em sala de aula provocando um debate entre os alunos. Nestas situações, os estudantes que trabalham com produção orgânica manifestaram-se demonstrando uma auto-estima positiva decorrente de suas atividades. Os educadores avaliam que tais situações e resultados foram, em grande parte, potencializadas pela posição de valorização da agricultura orgânica que eles assumiram.

\subsubsection{Autonomia e Fortalecimento}

Neste trabalho tomou-se como um dos objetivos gerais da educação: "contribuir para a emancipação dos educandos". Trata-se de auxiliar o educando a construir o seu próprio sistema de pensamento e de valores (Delors, 2000, p.59) através de subsidios informativos; incorporação ou descoberta de competências e habilidades; construção de conhecimentos; percepção de possibilidades e limites. Jacques Ardoino propõe o termo "se autorizar" como "a intenção e a capacidade conquistada de tornar-se a si mesmo seu próprio co-autor, de querer se situar explicitamente na origem de seus atos e, por conseguinte, dele mesmo enquanto sujeito" (1998, p.28). O mesmo autor lembra que o mais adequado é o termo "co-autor", pois o processo nunca será de auto-suficiência ou independência total.

Um instrumento de fortalecimento da autonomia, considerado importante pelo pesquisador, é o próprio exercício desta autonomia associado a um processo de aperfeiçoamento de competências e habilidades. Pedro Demo afirma que para a construção da autonomia do sujeito histórico "o instrumento primordial é o manejo e produção de conhecimento (1994, p.12). Neste sentido dois casos são emblemáticos:

i) A primeira situação a destacar envolveu a Prof. ${ }^{a}$ Hortência durante uma atividade em que os alunos eram levados a uma sala de aula previamente preparada e estimulados a observarem e refletirem sobre a limpeza e conservação da escola. Para a primeira turma a professora teve muita dificuldade na condução da atividade, necessitando uma grande intervenção do coordenador-pesquisador. Com a segunda turma a professora apresentou boa performance necessitando apenas algumas complementações. A partir da terceira turma a professora demonstrou domínio do procedimento e reelaboração do seu repertório, praticamente dispensando a intervenção do coordenador. 
ii) Outro exemplo é o caso da Profa . Jasmim que inicialmente apresentava um repertório sobre meio ambiente demasiadamente limitado, conforme indica o exercício de representação com arte (Apêndice 5). No transcorrer do curso notou-se uma pequena ampliação deste repertório, mas em uma reunião no início do semestre seguinte foi muito significativa sua fala sobre a necessidade de trabalhar com os alunos a noção de "qualidade de vida".

\subsubsection{AS RELAÇÕES COM A REALIDADE E COM O CONHECIMENTO}

A adoção das tecnologias modernas na agricultura sofre influência de uma racionalidade mais geral apontada por Tassara \& Damergiam em que novo é interpretado enquanto "um valor positivo que se impõe como bom e desejável em si" (1996, p.293). Esta interpretação implica na aceitação da mudança como natural, na desconsideração do caráter eletivo desse valor e na constituição de um quadro em que "mudança, novo e progresso têm significações similares, confundindo-se entre si em nível de competência semântica" (1996, p.293). Neste contexto, uma nova percepção da realidade incluindo a crítica à representação social hegemônica é elemento fundamental para a ruptura do consenso ideológico que sustenta o status quo ${ }^{10}$. A proposta é que a Escola auxilie na formação de agentes ruptores, ou seja, aqueles que acessam e apropriam-se de frações do universo teórico-racionaldiscursivo, tornam-se capazes de divulgar e produzir conhecimentos que beneficiem a si e a sua comunidade e principalmente tenham confiança, desejo e compromisso com tais opções. No caso deste estudo trata-se de buscar processos educativos que colaborem para formação de tais agentes ruptores voltados a uma nova racionalidade que sustente e valorize alternativas ao modelo agrícola atual.

A intervenção foi promovida "apostando" que a Escola pode tornar-se um espaço privilegiado para a realização e vivência desta ruptura que converge com aquelas apontadas no tópico sobre "Ciência e racionalidade". Mas para isto a Escola precisa cumprir aquele que Burnham considera o seu principal papel, ou seja:

\footnotetext{
10 "Para mandar e conservar no poder uma parte da sociedade (... ), a repressão serve menos do que a adesão, a força física serve menos do que a convicção ideal que implica a adesão e a cooperação voluntária. Portanto é necessário que dominantes e dominados partilhem as mesmas representações, a mesma ideologia, para que se possa produzir o fator mais forte do poder dos primeiros sobre os segundos, ou seja, o consenso fundado no reconhecimento da legitimidade de tal poder" (Godelier citado por Tassara \& Damergiam, 1996, p.313)
} 
"contribuir para que os educandos tenham acesso, a diferentes referenciais de leitura de mundo e de relacionamento com este mesmo mundo, proporcionando-Ihes não apenas um lastro de conhecimentos e de outras vivências que contribuam para a sua inserção no processo da história, como sujeitos do fazer dessa história, mas também para a sua construção como sujeito (quiçá autônomo) que participa ativamente do processo de produção e de socialização do conhecimento (Burnham, 1998, p.37).

Morin $(1984,14$ ) fala de um "pensamento que se engana" e que conduz à "ações mutilantes" observando que tal engano não é por insuficiência mas por incapacidade de ordenar as informações e os saberes. Neste contexto torna-se importante estimular, no processo educativo, a constituição de novas visões da realidade, implicando em mudanças essenciais nos pensamentos, percepções e valores da grande maioria dos seres humanos. O que está sendo proposto é mais que uma nova relação com os conhecimentos trata-se da formação das bases daquilo que Gadotti denomina de "cultura da sustentabilidade" (1999, p.24) uma cultura da vida, da convivência harmônica entre seres humanos e entre estes e a natureza.

Neste tópico são apresentadas considerações sobre a intervenção e suas relações com as questões agro-ambientais na perspectiva da constituição de novas relações com o conhecimento e com a realidade destacando-se:

- Novas escalas temporais, novas escalas espaciais/territoriais.

- Novas escalas e parâmetros valorativos ressaltando a ética e a bondade.

- Novas formas de olhar antigos objetos, processos e pessoas, gerando descobertas.

- Novo modo de compreender, reconhecendo o complexo e não simplificando.

- Nova forma de perceber-se e de perceber seus próprios atos.

- Descobrir a existência de múltiplas perspectivas.

- Produzir conhecimentos sobre a realidade local.

\subsubsection{Outros olhares e nova compreensão}

Propor outros olhares traduz-se em "desconstruir representações sociais sobre meio ambiente, desenvolvimento econômico, domínio da natureza, qualidade de vida, padrões de consumo, etc." (Reigota, 1998, p.48). Um novo olhar sobre o meio ambiente e as questões ambientais tem haver também com despertar o olhar para o cotidiano e para a estética da natureza. O primeiro passo é, como diz Isabel Carvalho, "sair de lugares habituais, que se pretendem universais, de onde aprendemos a olhar as coisas e identificá-las de um único 
ponto de vista" (1998, p.55). Outro passo seria superar as divisões disciplinares: "é preciso ter olhos para ver que o mundo da vida transborda as gavetas conceituais" (1998, p.36).

O encaminhamento do curso possibilitou à maioria dos cursistas significativas mudanças no olhar e nas interpretações sobre diversos aspectos da realidade. Estas mudanças caraterizam-se pela ampliação e aprofundamento de enfoques e aspectos diante de espaços, fenômenos, objetos ou sujeitos "já conhecidos"; pela descoberta e exercício da possibilidade de novos olhares; pelo reconhecimento da existência de perspectivas nos olhares e até pelo auto-conhecimento do papel de agente na observação. Entre as atividades que provocaram um grande impacto pessoal na quase totalidade dos educadorescursistas e contribuíram de forma destacada para tais mudanças estão: observação e representação sobre o entorno, debates coletivos e as palestras dos vários convidados.

Também a constituição de novas relações com o conhecimento foi muito diferenciada entre os envolvidos. Para alguns, importante foi desvelar a produção do conhecimento, para outros foi descobrir que os conhecimentos em especial os chamados científicos são transitórios e faliveis, para outros ainda, o mais significativo foi descobrir-se produtor de conhecimentos.

Apesar dos resultados diferentes para cada cursista, vários indicadores deixam nítido que se avançou no sentido dos objetivos. A necessidade de constituir um novo olhar e uma nova compreensão foi apreendida e muito bem expressada por um educador-cursista quando defendeu que entre os objetivos do projeto de sua equipe deveria constar: "Incentivar nos alunos uma nova forma de perceber" que agregasse o "amor à vida" e que implicasse em "mudanças de posturas" (Prof. Lobo - Reunião da Equipe E1 - Caderno de campo 12/07/1999).

As considerações feitas por uma professora, em seu texto de retrospectiva sobre o curso, indica a profundidade da descoberta de novos olhares:

"Será que sou eu, que pela primeira vez estou percebendo agora os fatos que sempre estiveram presentes?" ( $4^{\circ}$ parágrafo - Apêndice 28 ).

\subsubsection{Mídia}

Várias vezes os cursistas apresentaram a questão do poder da mídia sobre os estudantes (crianças e adolescentes) na construção de formas de olhar e compreender o 
mundo como, na constituição de valores e padrões de comportamento e como elemento dificultador em abordagens de temas alternativos, como é o caso da agricultura sustentável, (exemplo Apêndice 9).

$\mathrm{Na}$ atualidade observa-se o crescimento dos meios de informação de massa na disponibilização de dados e na indução de opiniões, comportamentos e modos de vida. O poder da mídia tornou-se tão grande que Castoriadis escreveu: "O essencial da educação que a sociedade contemporânea proporciona aos indivíduos não é a educação formal dispensada pelas escolas, mas sim aquela disseminada cotidianamente pela mídia, sobretudo pela televisão, pela publicidade, etc." (1998, p.61).

Tassara e Damergiam situam este poder da mídia no contexto da manutenção da hegemonia atual, em que ações de propaganda promovem "informação, contra-informação e desinformação estratégicas, as quais com maior ou menor grau de sistematização, objetivam influenciar as formas de representação da realidade histórica" (1996, p.297), produzindo "uma visão de absoluta pré-determinação do futuro histórico" (1996, p.300). Assim a difusão de propostas alternativas, enfrentam um processo em que ações de propaganda organizam temas e princípios visando reduzir o impacto da ação de difusão de processos autônomos propostos por forças sociais anti-sistemáticas (1996, p.292) como é o caso das propostas em agricultura sustentável.

Outro fenômeno que interessa ao objeto-processo aqui estudado é apontado por Tassara \& Damergiam. Dizem elas que, na medida que o meio urbano transforma-se em "lócus de convergência das grandes correntes de interesse econômicos, políticos e ideológicos", a mídia trata de reproduzir este modo de vida urbana como forma de garantir a hegemonia (1996, p.306). No caso brasileiro isto implica em reforçar um processo de desqualificação do modo de vida rural e de desvalorização dos produtos e dos trabalhadores rurais.

Guattari identifica uma tendência no capitalismo pós-industrial em migrar seu foco para as estruturas produtoras de signos, sintaxes e de subjetividade através do controle sobre a mídia, a publicidade e outros elementos (1995, p.31) e aponta a necessidade de "se desintoxicar do discurso sedativo que as televisões em particular destilam" (1995, p.24). Na mesma linha de preocupação com o poder e a capacidade manipuladora da mídia, Barbier propõem um papel ativo para a educação através da promoção de "um ensino crítico da semiologia da imagem publicitária e televisiva" (Barbier, 1998, p.178). 
Um aspecto geralmente negligenciado, mas que foi reconhecido por uma educadora-cursista, foi quanto a possibilidade que a Escola tem de oferecer a vivência direta e de por em contato os sujeitos, enquanto que a mídia, em especial a televisão, tem um tratamento "frio", distante, autoritário, não relacional e descomprometido. Esta avaliação converge com a reflexão de Castilla del Pino (citado por Gutiérrez \& Prado, 1999, p.88) que já em 1970 ressaltava a contradição entre a saturação de meios de informação coletiva e a incomunicabilidade vivida pela sociedade. Não é por acaso que as vivências e as inter-relações concretas com a realidade e com outras pessoas foram apontados como responsáveis por grandes impactos educacionais na intervenção, conforme será tratado nos itens seguintes.

\subsubsection{Vivências e atividades práticas}

Observações do pesquisador, avaliações dos educadores-cursistas e outros indicadores apontam que as situações práticas e/ou vivenciais, proporcionadas pelo curso ou pelos projetos, foram muito significativas aos processos educativos, contribuindo para os cursistas e em alguns casos para seus alunos:

- Incorporarem novos valores;

- Assumirem novas atitudes e comportamentos;

- Melhorarem relacionamentos interpessoais e

- Aumentarem o entendimento sobre a temática ambiental.

Um fato que se destacou foi o aumento considerável do interesse e do compromisso com a temática agro-ambiental após a visita aos estabelecimentos de produção orgânica.

Bárcena apresenta algumas considerações que auxiliam a compreensão sobre a importância das vivências no processo educativo: "não são os conhecimentos, as informações e nem as verdades transmitidas através de discursos ou leis que dão sentido à vida. $O$ sentido se tece de outra maneira, a partir de relações imediatas, a partir de cada ser, a partir dos sucessivos contextos nos quais se vive" (1999, p.14). Isto converge com que diz Nogueira: "É a vivência que permite ao Ser Humano exercer intelectualmente o ato de conhecer. Não é o contrário: não é a lista curricular que permite ao Ser Humano pensar e 'curiosar" a realidade" (citado por Sorrentino, 1996, p.59 e 60).

A realização de atividades escolares extra classe é amplamente aprovada pelos estudantes. Segundo declarações destes tal procedimento desperta interesse e facilita a aproximação e compreensão com os conteúdos teóricos. Diferente do que ocorre no cotidi- 
ano escolar, as vivências parecem possibilitar uma relação com a realidade e com a informação de modo mais direto, oferecendo uma maior concretude ao assunto. Muitas vezes nestas situações a mediação da linguagem verbal (escrita e falada) é reduzida ou até eliminada, enquanto que outras linguagens e relações são exercitadas e fortalecidas. Além disso os dados do trabalho apontam que as vivências e atividades práticas em processos educativos tendem a provocar, modificar e fortalecer as múltiplas relações entre educandos, entre educadores e entre educandos e educadores.

As vivências empreendidas, incluindo as sensações e emoções provocadas e as descobertas de novas perspectivas diante elementos, lugares e situações cotidianas, parecem contribuir enormemente para despertar a sensibilidade dos envolvidos. Aqui entendese sensibilidade como proposto por Barbier: "forma elaborada do sentimento de ligação (reliance), 'uma empatia generalizada' em relação a tudo o que vive e a tudo o que existe" (Barbier, 1998, p.183). Este autor complementa seu pensamento dizendo que há três tipos de sensibilidade: a sensibilidade ecológica (que faz com que sintamos envolvidos pelo equilibrio da vida na terra), a sensibilidade ética (que envolve o sentido da bondade) e a sensibilidade estética (ligada ao belo). Luiz Carvalho (2000) ao tratar especificamente da formação de educadores ambientais defende que estes tenham oportunidades de "experimentarem a beleza da natureza".

Três exemplos são representativos dos impactos das vivências e atividades práticas sobre os educadores cursistas:

a) A visita ao Parque Estadual do Jurupará realizada pelos membros da equipe $E 2$, foi um marco do compromisso destes com as questões ambientais, do envolvimento com o projeto da equipe, do fortalecimento do grupo e da empolgação com o desenvolvimento de trabalhos com os estudantes.

b) O plantio e manutenção coletiva da horta. Sobre estas atividades e seus impactos o pesquisador registrou cinco educadores em momentos distintos realizarem depoimentos extremamente emocionados e veementes (exemplos ver parágrafos $8,9 \mathrm{e}$ 10 - Apêndice 21).

c) O relato de uma professora sobre a mudança de relacionamento com seus alunos após realizarem uma atividade de rega de mudas de árvores (parágrafos 39 e 40 Apêndice 21). 


\subsubsection{RELAÇÕES INTERPESSOAIS}

Duas importantes facetas das relações interpessoais na educação estiveram presentes na intervenção:

- i) As relações entre pessoas como meio essencial nos processos educativos.

- ii) O aperfeiçoamento das relações pessoais enquanto um objetivo educacional.

Há várias relações interpessoais inerentes e ou promovidas em processos educacionais, incluindo as relações educadores-educandos, educandos-educandos e educadoreseducadores. Estas situações são importantes pois possibilitam aprender na relação com o outro, aprender juntamente com o outro e aprender ao ensinar o outro. Barbier entende que a relação interpessoal é fundamental ao ser humano, pois no diálogo (que inclui também o conflito) o outro exerce a função de um "espelho ativo" possibilitando à pessoa descobrir seus "valores essenciais" (1998, p.169).

"Aprender a viver juntos" é apontado como o mais importante entre os quatro pilares da educação identificados pela Comissão Internacional sobre Educação para o Século XXI ,conforme seu Relatório para a UNESCO (Delors, 2000). Segundo este documento trata-se de promover a dimensão social do ser humano o que inclui a compreensão mútua, o respeito pelas especificidades individuais, o contato com a história do outro, o reconhecimento da interdependência, a realização de projetos comuns, o desenvolvimento da solidariedade e o exercício da democracia.

A importância da educação estimular as relações interpessoais torna-se evidente se forem aceitas as avaliações de Tassara \& Damergiam de que: "Estamos diante de uma crise do humano, ameaçado em sua sobrevivência devido a impossibilidade da troca da experiência e dos investimentos afetivos indispensáveis à constituição da subjetividade e da alteridade" (1996, p.306).

Ao tratar especificamente de processos em E.A. Bárcena também ressalta o valor das relações pessoais : "É na relação pessoal e grupal, no fazer diário, que se consolida a tomada de consciência ambiental e o sentido de trabalhar por um meio ambiente sadio" (1999, p.14).

Porém, em geral, nas escolas os relacionamentos interpessoais são desprezados, tanto na sua dimensão meio como na sua dimensão fim, só aparecendo enquanto problema. Entre os educadores um dos principais problema levantado é a rotina de trabalho seme- 
Ihante a uma linha de montagem na qual cada professor é responsável por uma peçadisciplina. A estrutura escolar, a grande carga horária de trabalho, a necessidade de trabaIhar em várias escolas, a grande rotatividade anual e outros problemas gera poucos momentos de interface entre os educadores. Nestas condições, geralmente, as relações tornam-se deficientes, caracterizando-se pela superficialidade e pequeno entrosamento.

Porém este quadro de crise, apesar de vivido, ainda é pouco compreendido, conforme ilustrou o comportamento dos educadores durante o primeiro encontro do curso. Nesta ocasião os participantes expressaram ser desnecessário a apresentação dos participantes pois: "- Nós já nos conhecemos: trabalhamos juntos!". Decorridos alguns encontros e considerando os procedimentos de estímulo à aproximação entre os envolvidos e ao fortalecimento das equipes, os educadores reconheceram que apesar do convívio diário desfrutado por muitos, suas relações eram pautadas quase exclusivamente por aspectos profissionais sendo pequeno o conhecimento interpessoal. Em vários depoimentos os educadores manifestaram que sentem falta de "espaços e momentos" de diálogos extraprofissionais com os pares (Apêndices 12, 18 e 21). Isto pode ser ilustrado pela aprovação da maioria da turma quanto a seguinte fala de uma cursista durante uma avaliação do andamento do curso:

- "É tipo uma terapia, né? Acho que a gente ouve coisas que a gente nunca imaginava ouvir, a gente vai se surpreendendo com as pessoas.(...) falam coisas bastante interessantes, bem sensiveis, as pessoas do grupo" (Apêndice 12, parágrafo 17).

Outra avaliação que denota a importância das relações interpessoais no processo educativo foi a seguinte declaração de uma cursista:

(Fala da Profa. Ceci) Outra coisa que eu gostaria de incluir (...) e que eu acho que, de modo geral, os outros colegas são testemunhas disto: 'O relacionamento entre todos os professores das várias escolas durante este curso também foi muito importante, porque ele foi ampliado, agora não somos mais colegas de trabalho atuando uma escola, nós somos amigos'. Eu acho que isto também começou no curso e foi se estendendo em todas as atividades em todos projetos: uma melhoria na relação humana, isto eu acho o bem de maior valor (Apêndice 21, parágrafo 41).

Em seu texto "Curso de Educação Ambiental: Retrospectiva", a cursista profa Safira também tratou sobre o estreitamento de relações humanas durante o processo e apresentou sua interpretação, vinculando o fato à postura dos educadores-palestrantes: 
"Senti que os profissionais que abraçam realmente as causas ambientais têm o cotidiano construído pelo laço do amor que une incondicionalmente todos os seres e o ambiente físico. Esta emanação amorosa dos mestres conseguiu unir, nós professores em curso, fazendo nascer um compromisso recíproco para as causas ambientais, e como seres humanos, um laço mais sincero, sólido entre colegas professores" (Apêndice 26).

Quanto à relação educador-educando a pesquisa confirmou várias condições que dificultam enormemente esta fundamental relação pedagógica, como: classes super lotadas; educadores trabalhando com várias centenas de alunos; periodos de contato com os estudantes (aulas) curtos e fragmentados. Mas, apesar destes problemas, alguns acontecimentos envolvendo relações educador-educandos foram de extrema significância para os atingidos e para a pesquisa. Trata-se da promoção de trabalhos coletivos vinculados aos projetos das escolas, os quais são ilustrados com um relato carregado de emoção sobre o mutirão de plantio da horta (Apêndice 21).

\subsubsection{Agressividade}

Constantemente durante as diversas visitas às escolas e nos depoimentos de educadores foram apontados problemas envolvendo a indisciplina e o desrespeito dos alunos com os educadores. Porém o maior e mais grave problema observado foi a agressividade banalizada envolvendo pré-adolescentes e adolescentes, atingindo e prejudicando enormemente alunos, professores e demais profissionais do meio escolar. Não parecendo absurdo ao pesquisador a denominação "epidemia"11 de agressividade.

O tema da agressividade esteve presente em três dos quatro projetos propostos no contexto da intervenção, seja na condição de fator prejudicial ao projeto, seja como problema a ser enfrentado ou ainda como comportamento atingido e influenciado pelo projeto.

Os educadores-cursistas da Equipe 1 ao detalharem suas propostas apontaram como possíveis problemas para a promoção do projeto a indisciplina e o vandalismo dos estudantes e defenderam a necessidade cercar a horta contra ações de depredação. Porém, com a implantação dos canteiros, o observado foi a redução de tais problemas. Desta-

${ }^{11}$ Esta avaliação decorre de depoimentos dos educadores de lbiúna e São Roque, do acompanhamento de algumas de suas turmas; de observações e entrevistas junto a uma escola rede pública municipal da São Paulo-SP (trabalho de extensão universitária); observações e entrevistas em uma escola pública estadual em São Bernardo do Campo-SP (durante estágio de 4 meses); depoimentos de educadores durante diversos cursos e eventos que o pesquisador participou nos últimos 30 meses. 
cando-se a diminuição da agressividade dos educandos, fato testemunhado pelo pesquisador e confirmado enfaticamente por todos os educadores envolvidos, pelo coordenador pedagógico da escola, pelo inspetor de alunos e até por pais de estudantes (parágrafo 21 Apêndice 21 ).

No caso da Equipe 4, um dos objetivos constantes na proposta inicial do projeto educacional era: "Colaborar para a melhoria das relações humanas da turma envolvida". Conforme declarado em reunião, a intenção era trabalhar e valorizar a cooperação, as relações interpessoais e a formação de equipes de educandos. $O$ enfoque do projeto e a escolha da turma foi uma decorrência do diagnóstico que identificava uma alta incidência de intolerância, desunião e violência na turma.

Apesar deste tema não aparecer na fase de planejamento da Equipe 2, na avaliação final, foi muito significativo o depoimento de uma professora sobre a redução de atritos e a melhoria de relacionamento entre ela e uma determinada turma após uma experiência de atividades extra classe do projeto (parágrafos 39 e 40 - Apêndice 21).

\subsubsection{Participação e Pertencimento}

A educação deve contribuir para que cada um situe-se na comunidade a que pertence (Delors, 2000). A escola é uma instância extremamente propícia à constituição da noção de pertencimento o que inclui: reforçar a identidade coletiva, consolidar valores solidários, valorizar o trabalho cooperativo e exercitar a participação cidadã ativa.

As iniciativas e situações visando o estreitamento das relações pessoais e o fortalecimento das equipes de educadores nas escolas contribuíram significativa para ampliar o sentimento de pertencimento, o senso de responsabilidade e o compromisso com os projetos e com os colegas. A preocupação com a formação de equipes é compartilhada por Sato (2000) que considera a existência destas um fator contribuinte para a sustentabilidade de iniciativas em E.A. Por sua vez os cuidados no sentido do fortalecimento coletivo converge com um movimento apontado por certos autores quanto a emersão do grupo como um novo sujeito histórico (Tassara \& Damergiam, 1996, p.300).

Entre as iniciativas reconhecidas como colaboradoras na ampliação da noção de pertencimento à comunidade destacam-se as pesquisas locais e o desenvolvimento dos projetos educacionais em especial suas atividades extramuros. De modo geral os quatros projetos focalizaram participação e pertencimento: 
- O projeto da Equipe 1 tinha entre os objetivos o resgate e a valorização da cultura agrícola, traço importante da comunidade. Posteriormente a horta implantada constituiu-se em um "bem construído coletivamente" e que passou a compor a caracterização da escola.

- O projeto da Equipe 2, além de estimular a participação sinalizava através do termo "nosso" em seu título (Valorizando as Árvores em Nosso Municipio) a preocupação com a noção de pertencimento.

- A Equipe 3 em grande parte centralizou sua proposta na noção de pertencimento à escola ao envolveu toda a comunidade escolar numa participação ativa na confecção de diagnósticos e de levantamentos de desejos sobre o meio ambiente local.

- Já a Equipe 4 apresentava entre suas intenções a formação e fortalecimento de "equipes de alunos" as quais seriam estimuladas a formularem propostas de trabalhos que envolvessem a comunidade do entorno da escola.

Muitas vezes, em situações que possibilitaram a manifestação dos alunos, verificouse posicionamentos críticos e criativos e um anseio por uma atuação mais ativa. Durante o Encontro de Encerramento do Curso ocorreram várias manifestações deste tipo, como o questionamento incisivo sobre preços durante a palestra do comerciante de produtos orgânicos. Outro exemplo de participação ativa dos estudantes ocorreu durante discussões com alunos da Escola 2 sobre o projeto da equipe de educadores. Na ocasião os estudantes apresentaram várias sugestões de trabalhos, lugares e temas de pesquisas, além de apontarem a necessidade de definir critérios para participação nos projetos destacando o fator "compromisso" com o mesmo. Também ocorreram várias ocasiões em que estudantes apresentaram-se como voluntários para atividades dos projetos e seus desdobramentos.

As observações, como a exemplificada acima, sinalizaram que procedimentos proporcionando uma postura mais ativa dos alunos podem criar importantes vínculos entre educandos e educadores e entre os conhecimentos teóricos e a realidade dos educandos. Porém isto parece estar sendo pouco aproveitado no processo educativo. Ocorre que articular o processo educativo com o anseio dos estudantes por situações mais ativas não é uma tarefa simples. É preciso que a Escola se reorganize e os educadores aprendam a incentivar e aproveitar educacionalmente este interesse. Algumas situações em que o número de participantes nos projetos foi ampliado ocorreram dificuldades de condução, pois esbarrou-se no limite da capacidade de planejamento e coordenação do processo, resultando em um baixo aproveitamento educacional para a maioria dos envolvidos, podendo ser citado dois exemplos: a atividade de levantamento da arborização urbana (Equipe E2) e o Festival do Meio Ambiente (Equipe E3) detalhados no Apêndice 2. 


\subsubsection{ABORDAGEM EDUCACIONAL AGRO-SÓCIO-ECOLÓGICA}

\subsubsection{Educação ambiental}

A educação ambiental é um dos eixos orientadores da pesquisa, da intervenção promovida e do assunto abordado na intervenção, portanto está presente em quase todos os tópicos anteriores. A seguir serão feitas algumas novas considerações e eventualmente a retomada de tópicos sobre abordagens em E.A.

Em um questionário (Apêndice 25) respondido antes do início do curso, 12\% dos cursistas avaliaram como "grande" os seus conhecimentos sobre questões ambientais e sobre educação ambiental, $69 \%$ consideraram "médio" os seus conhecimentos e $19 \%$ comiseraram "pequeno". Quanto a experiência em educação ambiental, 50\% dos cursistas classificaram como "média", $44 \%$ consideraram "pequena" e $6 \%$ acharam "muito pequena" sua experiência. Porém as auto-avaliações dos educadores-cursistas contrastam com o diagnóstico feito pelo pesquisador, inclusive considerando outras respostas no mesmo questionário, em especial, aquela sobre o entendimento de educação ambiental. Percebese uma grande diferença entre as concepções iniciais sobre educação ambiental e aquele conjunto de princípios e conceitos apresentados neste trabalho (item 2.3.3). Esta diferença pode ser observada nos painéis e falas dos cursistas durante uma atividade no $1^{\circ}$ encontro do curso (Apêndice 5).

A partir das respostas ao questionário acima citado, das manifestações em atividades com os cursistas (Apêndices 5 e 6) e de outros levantamentos, o pesquisador produziu uma tipificação das posturas educacionais iniciais dos cursistas diante das questões ambientais, resultando no delineamento de três posturas: "semeadora", "cultivadora" e "simpatizante".

Denominou-se "semeadora" a postura daquele educador cuja preocupação central é "sempre e por toda parte 'semear' idéias, informações, preocupações e propostas", alimentando a esperança que algumas destas sementes darão "frutos". Nos discursos associados à postura semeadora aparecem frases como: "se pelo menos alguns ... já valeu a pena" ou então: "É impossível que a gente fale, fale e os alunos não mudem nada" ou ainda "nada é em vão, sempre fica alguma coisa". Esta postura parece sofrer grande influência da educação centrada da disponibilização de informações. 
Já na postura "cultivadora" os educadores além de "semear" desejam "colher os frutos" ou seja desejam perceber os "resultados" do processo educativo. Preocupados com as repercussões de suas "sementes-idéias", estes educadores argumentam: "de nada adianta nota dez na escola e zero na vida". Na busca por processos educacionais que contemplem seus anseios, estes educadores tendem a valorizar temas e ações práticas no e do cotidiano dos educandos.

A postura "simpatizante" é aquela dos educadores que apesar de terem um comportamento pouco ativo, consideram adequadas as preocupações ambientais e valorizam as posições e iniciativas anteriormente citadas.

Considerando a tipificação acima, identificou-se entre os cursistas o seguinte perfil: $22 \%$ aproximavam-se da postura "semeadora", $28 \%$ adotavam a postura "cultivadora", $28 \%$ apresentavam uma postura intermediária entre semeadora e cultivadora e os demais $22 \%$ eram "simpatizantes".

Quando estimulados a planejarem e executarem projetos em E.A. verificou-se que os educadores de postura "cultivadora" e de "transição semeadora-cultivadora" encamparam o enfoque da resolução de problemas e da promoção de ações. Contando com o apoio dos educadores simpatizantes e dos educadores com postura semeadora que se sentiram contemplados na proposta.

Quanto aos estudantes observou-se que a maioria apresentava um interesse médio e alguns um grande interesse em relação às questões ambientais. Em geral este interesse era maior quando eram enfocados temas que os atingia diretamente como caça, pesca, animais domésticos e impactos sócio-ambientais da agricultura. Mesmo abordagens simplistas e superficiais foram recebidas com interesse pela maioria, um exemplo foi as manifestações de interesse verificadas durante palestra proferida por um policial florestal para estudantes da Escola 2 a qual gerou repercussões nas salas de aula nos dias seguintes. 


\subsubsection{Agricultura e Meio Ambiente enquanto tema educacional}

A seguir será apresentado alguns dos principais pontos envolvendo o tratamento educacional sobre as relações agricultura e meio ambiente identificados nesta pesquisa.

- Aproximadamente 2/3 dos alunos das escolas participantes na pesquisa eram agricultores ou filhos de agricultores e acumulavam conhecimentos práticos e experiências sobre o assunto. Mais que conhecer, alguns estudantes sofriam na pele, literalmente, os impactos da agricultura moderna. A referência aqui é ao relato de uma educadora-cursista que ao tratar o tema dos agrotóxicos ouviu de um aluno (agricultor) o depoimento de que os pelos de seu corpo estavam caindo devido a tais produtos. Nesta situação, em que a maioria dos estudantes vinculava-se à agricultura, alguns pontos apresentaram-se como relevantes no tratamento educacional do tema:

- Oassunto abarcava questões vitais e cotidianas para os alunos, como a necessidade imediata de produção e os custos e riscos de propostas agrícolas alternativos.

- Geralmente os estudantes apresentavam opiniões consolidadas sobre o tema, construídas ao longo do tempo, a partir de suas histórias de vida e de seus pais ou parentes próximos, das pressões exercidas pela mídia e dos comportamentos predominantes no país como a desvalorização do trabalho e modo de vida rural, a exploração irresponsável dos recursos naturais e a imprudência diante das questões ambientais.

- Em função dos dois pontos acima, muitas vezes, estes estudantes apresentavam resistências à críticas e dominavam um discurso de justificação do modelo agrícola atual, que inclui aquela idéia de "fatalismo químico" comentada na revisão bibliográfica.

- Diferente do que foi pressuposto inicialmente, constatou-se que a maioria dos educadores-cursistas já conheciam muitos problemas sócio-ambientais relacionados à agricultura, principalmente aqueles devidos ao uso intensivo de agrotóxicos tais como: contaminações de alimentos, solo e água; intoxicações, acidentes e doenças de trabalho; suicídios relacionados à agroquímicos e outros problemas. Mas estes conhecimentos limitavam-se aos problemas associados à agricultura moderna, não havia uma abordagem mais integradora destes tópicos, não eram tratados os processos agro-ecológicos ou iniciativas alternativas em agricultura. Parte dos conhecimentos dos educadores-cursistas decorriam dos contatos com seus alunos. Também ocorriam aqueles que conheciam o tema em decorrência de experiência pessoal. Em geral o assunto não havia sido tratado nas formações iniciais dos professores (licenciatura). 
- A articulação dos pontos anteriores auxilia a compreensão da postura e do tipo de tratamento empreendido pelos educadores diante do assunto. Ocorre que por apresentarem uma menor familiaridade com o assunto do que a maioria de seus alunos os educadores receando uma situação de desvantagem cognitiva tendiam a promover um tratamento superficial limitando-se à programação curricular. Após participar do curso sobre relações agro-ambientais a maioria dos educadores assumiu uma postura exatamente inversa. Muitos relataram que atualmente aproveitam "ganchos" temáticos ou mesmo conversas paralelas para colocar em pauta o assunto.

- Uma dificuldade prevista desde o início dos trabalhos, diz respeito às limitações da educação sozinha promover mudanças de atitudes. Luiz Carvalho (2000) é um dos autores que levanta a necessidade de observar os limites da educação enquanto instrumento de mudança, considerando que há uma supervalorização desta em função de posições definidas como "ilusão pedagógica, otimismo pedagógico ou entusiasmo pedagógico" (Nagle citado por Carvalho, 2000). Mas, além dos limites pertinentes a qualquer processo educativo, o assunto e o enfoque proposto neste trabalho, apresenta algumas particularidades quanto a sua capacidade de influir em mudanças de atitudes e de comportamentos individuais, quando comparado à abordagem de outros temas ambientais.

Inicialmente deve-se considerar que a maioria das questões ambientais envolve uma complexidade de aspectos e fenômenos de natureza social, cultural, ecológica, econômica, política, psicológica e outras. Porém, muitas delas permitem a atuação isolada do indivíduo, em consonância com a proposição de "pensamento global e ação local", como por exemplo a eliminação de desperdícios ou o combate à poluição. Qualquer pessoa tem possibilidade de decidir e de implementar uma redução de desperdício ou uma economia de recursos naturais. O mesmo se dá em relação ao combate a alguns tipos de poluição, como a sujeira em ambientes naturais ou urbanos, qualquer um pode decidir e contribuir para a redução deste problema, por exemplo destinando apropriadamente o lixo e as sobras de suas atividades e até promovendo ações de limpeza. Uma sinergia entre as duas preocupações pode, inclusive, promover a coleta seletiva e a reciclagem de lixo reduzindo a poluição ambiental e o consumo de recursos naturais.

Nesses casos a ação individual não resolve o problema, mas permite uma contribuição, mesmo que pequena. $O$ agente faz sua a parte e caso muitas pessoas também adotem a nova postura poderá haver a diminuição do problema. O que se quer destacar aqui é a existência de uma autonomia relativa do agente pois, a execução da ação (contribuição 
pessoal) não depende de outra pessoa. Além disso a prescrição diante do problema é pouco contestada e apresenta características sinérgicas :

- A ação gera benefícios imediatos e mensuráveis ao agente. Exemplificando: a redução de desperdício reduz as despesas; a manutenção de ambientes limpos evita insetos e doenças e gera "prazer estético" e a coleta seletiva pode gerar ganhos econômicos;

- Possui uma convergência entre saber científico e o senso comum;

- Não chega a impor grandes sacrifícios aos interesses econômicos hegemônicos, sendo que muitas vezes tais prescrições são patrocinadas por estes interesses inclusive como forma de "marketing" institucional;

- Não apresenta resistência entre os que detêm o poder político. Semelhante ao que ocorre com o poder econômico, estas prescrições são absorvidas e até utilizadas para geração de dividendos políticos.

O processo educativo sobre tais propostas beneficia-se desta convergência de interesses e aparente consenso, o que possibilita o uso de argumentos com uma boa capacidade de convencimento. Não se trata de afirmar que estes sejam os melhores argumentos, ou que a argumentação racional seja a única e ou mesmo a melhor forma de atingir o educando. Apenas ressalta-se que, nestes casos, as perspectivas imediata, local e individual são relativamente contempladas, sem necessidade de confronto e muitas vezes com o apoio dos beneficiados pelo "status quo".

Já o tratamento educacional das relações entre agricultura e meio ambiente, na perspectiva proposta, apresenta condições diferentes:

- é um assunto pouco considerado pela "ciência moderna". Apesar de existirem muitos cientistas trabalhando o assunto, eles são marginalizados e enfrentam atuações de cientistas e instituições comprometidas direta ou indiretamente com as empresas e outras organizações beneficiárias do modelo atual;

- as avaliações e proposições apresentadas afrontam o poder econômico em vários níveis, desde os comerciantes locais até as grandes multinacionais de insumos;

- o senso-comum sobre o assunto apresenta uma adesão ao discurso e propostas da Revolução Verde atrelado a racionalidade modernizante e uma postura desqualificadora das propostas alternativas, em especial aquelas que envolvem o saber tradicional; 
- os técnicos que trabalham com agricultura, geralmente, possuem poucos conhecimentos ou acesso a informações sobre as propostas alternativas. Mas acumulam experiência e conhecimentos do modelo convencional, o qual garante uma certa previsibilidade e segurança na atuação profissional a curto prazo.

- mesmo quando o educando reconhece alguns problemas e incorpora determinadas preocupações agro-ambientais, a sua atuação individual, que no caso seria a conversão para a agricultura alternativa, muitas vezes não é possível devido a sua condição de empregado ou então pela necessidade de investimentos iniciais ou ainda pela dificuldade de comercialização de um produtor isolado.

Também junto aos consumidores de produtos agrícolas há uma dificuldade de promover mudanças de comportamentos. Neste caso um grande problema é a diferença de preço final dos produtos convencionais e alternativos, aspecto que se agrava devido a miséria ou a pobreza de grande parte da população.

- Mas, apesar destas limitações, a intervenção educacional sobre agricultura e meio ambiente pesquisada obteve importantes avanços na direção do objetivo de envolver os participantes educadores nas lutas agro-ambientais. Três procedimentos contribuíram enormemente para o relativo sucesso desta iniciativa:

i) A visita a estabelecimentos onde se pratica agricultura orgânica. Avaliada como muito eficiente, a visita além de subsidiar a ampliação de repertórios dos envolvidos, possibilitou aos envolvidos perceberem a viabilidade da agricultura orgânica, conforme indicou a avaliação de um cursista no dia: (...) A gente está vendo a possibilidade de reverter (...) Vemos os produtores comentando as vantagens, os benefícios e o otimismo deles (...) (Prof. Carneiro, Apêndice 11).

ii) as atividades visando contextualizar o assunto em relação às proposições ambientalistas e aos novos paradigmas de racionalidade e de ciência. Esta contextualização torna-se ainda mais pertinente quando se considera a necessidade de mudanças sistêmicas.

iii) a implementação de uma horta orgânica numa escola tomada como instrumento educacional foi outro procedimento extremamente impactante, o qual será discutido no tópico seguinte. 


\subsubsection{A Horta Orgânica na escola - cultivo, cultura e culto}

A formação e manutenção de uma pequena horta orgânica em uma escola (E1), tomada como um recurso educacional, proporcionou uma diversidade de impactos entre educadores e educandos.

Inicialmente cabe informar que o coordenador pedagógico e alguns professores da escola já intencionavam realizar um trabalho com hortas, o que o curso influenciou foi a opção pelo enfoque orgânico.

Alguns problemas foram enfrentados no desenrolar do projeto, sendo os principais:

- carência de materiais básicos para o trabalho (enxadas, terra com matéria orgânica, etc.);

- dificuldades de operacionalizar os trabalhos com turmas de até 45 alunos como falta de espaço nos canteiros para a circulação de grande número de alunos e problemas para dividir e controlar as tarefas;

- conforme já apontado, desde o início da formulação da proposta, entre os educadores-cursistas houve uma tendência de valorizar a ação empreendida. Visando apresentar um contraponto a esta tendência e destacar o componente educacional da iniciativa, o pesquisador procurou fortalecer a idéia, surgida na própria equipe, de conceber a horta como um "laboratório vivo" voltado a processos educativos, porém isto foi pouco assimilado pelos envolvidos.

- insuficiência de carga horária específica na estrutura escolar para o planejamento, preparação de aulas e articulação das atuações dos educadores participantes, o que contribuiu para um menor aproveitamento da horta como um "laboratório vivo".

Apesar destes problemas a implantação da horta orgânica na escola gerou diversos pontos positivos, alguns deles serão comentados a seguir.

=> A iniciativa obteve grande apoio da comunidade escolar incluindo vários professores (não cursistas), funcionários (serventes e inspetores de alunos), alguns pais de alunos e até vizinhos da escola. O professor de história pintou o muro da área da horta, a professora de língua estrangeira prontificou-se a montar painéis de identificação em inglês dos cultivos e das ferramentas. Alunos de outras turmas começaram a solicitar a participação no projeto. Alguns pais de alunos cederam materiais e outros ofereceram colaboração 
ao projeto. Ao relatar que os alunos atendiam prontamente suas solicitações de materiais para a horta, enquanto que outros passaram a trazer outros materiais não solicitados (mudas, sementes, etc.), uma professora exclamou:

- "É impressionante a mobilização dos alunos"! (Profa Sara, Caderno de campo do pesquisador, 17/11/99).

=> A horta mobilizou também alguns moradores do entorno da escola que se mostraram curiosos e interessados na iniciativa, passando a acompanhar o crescimento dos cultivos (caderno de campo, 17/11/99) e até a vigiar contra depredações.

=> O enfoque em um tema agrícola contribuiu para resgatar conhecimentos, experiências e valores rurais/agricolas e foi qualificado positivamente pelos alunos e seus pais, implicando em uma valorização da instituição escolar.

$\Rightarrow$ Diversos indicadores apontam que o projeto possibilitou a melhoria da autoestima dos participantes. A interpretação de alguns educadores envolvidos foi que a horta possibilitou aos alunos satisfazerem a necessidade de se mostrarem úteis. Isto converge para uma interpretação de Hernández para o qual uma das possibilidades dos projetos é que neles todos os alunos podem encontrar seu papel (1998, p.85).

=> $O$ testemunho de diversos professores (Apêndice 21) e o acompanhamento de algumas atividades pelo pesquisador indicaram que o manuseio da terra e de vegetais durante a limpeza do terreno, a preparação dos canteiros, a semeadura e o plantio de mudas repercutiu de forma extremamente intensa nos participantes.

=> Depoimentos dos professores apontam um relativo aumento de interesse, de concentração e de participação em sala de aula das turmas participantes do projeto.

=> O "lugar" horta parece agir como "catalisador de energias e de informações positivas" e como "dreno de ansiedades e aflições". Conforme disse uma professora da equipe: "o manuseio da terra parece ativar sentimentos positivos e estimular o equilibrio entre os envolvidos".

=> A situação de trabalho coletivo na horta afetou intensa e profundamente os principais envolvidos, possibilitou aproximação, diálogo e aumento do respeito e entrosamento entre educandos e educadores e entre educandos. Diversas avaliações apontaram uma substancial melhoria nos relacionamentos interpessoais dos alunos refletida no comportamento em sala de aula e na redução da indisciplina e da agressividade. 
Alguns dias após o início dos trabalhos práticos na horta orgânica uma professora não cursista apresentou a seguinte manifestação:

- "Achamos um jeito de trabalhar aqueles alunos difíceis." (Professora I da Escola 1, Anotações do caderno de campo).

No caso a professora referia-se aos alunos muito indisciplinados que tumultuavam as aulas ou aqueles que ficavam no pátio da escola sem ingressarem nas salas. Foram estes que foram chamados a auxiliar no trabalho inicial de limpeza do terreno e na formação da horta.

Aqui surgem questões importantes para o trabalho: Qual(is) a(s) interpretação(ões) para as observações, relatos e testemunhos envolvendo a horta? Quais os fatores e processos envolvidos? Qual o grau de especificidade destas observações?

Um ponto a considerar é que projetos educacionais, principalmente quando possuem ações práticas, são ocasiões em que professores e alunos compartilham objetivos comuns, ou como disse uma cursista, momentos em que "as pessoas se igualam como seres humanos" (Apêndice 21). Isto tem um grande valor na medida que na tradição escolar estes atores são colocados em confronto, principalmente pela hierarquização de seus papeis e pela desqualificação dos conhecimentos e capacidades dos educandos.

Um importante colaborador na melhoria dos relacionamentos interpessoais foi a dinâmica de trabalho criada para limpeza do terreno e preparação da horta, a qual incluiu um mutirão de vários dias que, além dos cursistas, contou com auxílio de outros professores e de alunos voluntários. Esta situação, em que professores juntamente com alunos "colocaram a mão na massa" (conforme suas palavras), repercutiu muito positivamente entre os estudantes da escola e em especial entre aqueles diretamente envolvidos no projeto. Em seguida, durante os trabalhos de plantio e manutenção da horta, constitui-se uma outra situação de aproximação entre educadores e educandos. Devido a área comportar poucas pessoas, os alunos eram divididos em pequenos grupos que se revezavam nas tarefas diárias da horta. Acompanhando e trabalhando junto com o grupo geralmente havia um professor que aproveitava a situação e estimulava diálogos desde assuntos mais próximos do "universo jovem", passando por questões ligadas à escola e aos seus agentes (professores, diretores e funcionários) até temas técnicos envolvendo a horta, estes últimos muitas vezes conduzidos por alunos com experiência agrícola.

Uma educadora ao avaliar seus sentimentos e observações sobre trabalhar direta- 
mente com a terra afirmou: "Trabalho gostoso de fazer, é uma terapia!" (Profa . Sara, caderno de campo 27/10/99). Esta avaliação converge com um certo impeto manipulatório que Bachelard, estudando as repercussões da imaginação diante dos elementos terrestre, identifica e escreve: "parece que as matérias terrestres, assim que as pegamos com a mão curiosa e corajosa, excitam em nós a vontade de trabalhá-las" (1999, p.1).

Os impactos nos relacionamentos decorrem de um conjunto de vetores, porém chama atenção a interpretação de uma participante: "há uma força que vem da terra, que age no ser humano, mudando o comportamento (...) e integrando as pessoas" (Prof ${ }^{\text {. }}$ Sara, Anotações de campo 27/10/99).

A redução da agressividade certamente vincula-se a uma diversidade de fatores, entre eles, a necessidade de delicadeza no manuseio das mudas, como disse uma professora: "- Os cuidados que as plantas requerem é tal qual um bebe!" (Profa. Sara, Caderno de campo 27/10/99).

Baseado em uma longa experiência com trabalhos ao ar livre Joseph Cornell afirma que as experiências diretas com a natureza nos "ajudam a descobrir dentro de nós um profundo sentimento de pertinência e compreensão e complementa: "depois de um contato direto e profundo com a natureza, a mente torna-se tranqüila e receptiva" (1997, p.38).

Repercussões positivas associadas a hortas escolares são apontadas por outros pesquisadores. Segura em seu estudo sobre experiências em E.A., ao abordar 7 casos de montagem de hortas em escolas, comentou: "Os fatores que sobressaem nessa prática é a convivência mais descontraída, a motivação dos alunos e a valorização do ambiente escolar". A autora aponta alguns elementos desse tipo de iniciativa: "Em meio a tantas grades, trancas e pichações, a horta apresenta-se como uma alternativa para tornar o espaço escolar mais agradável, mais familiar e resgatar valores desgastados, como a cooperação e a conservação" (1999, p.65). Em outro momento a pesquisadora escreve que ao discutir com alunos o significado da horta escolar "as respostas apontaram o aumento da auto-estima e do interesse pela escola" e transcreve algumas falas reproduzidas a seguir, em função da convergência com os resultados do presente trabalho:

"Aluno 1: Então, foi um trabalho de equipe, geral, e ajudou mais no interesse. (a horta) valoriza a escola e o aluno.

Aluno 2: Porque você está tocando, sentindo... Agora, se você fala só na sala de aula, você só tem conhecimento. Fica só na teoria. 
Aluno 3: É possível fazer, unir a teoria à prática. Fazer o que está ao nosso alcance com o mundo que está aí fora" (Segura, 1999, p.134).

Uma outra dimensão interpretativa sobre os impactos e os desdobramentos associados à horta escolar e, em especial, à manipulação da terra, emerge quando se considera:

i) a avaliação de Leis para o qual a crise ambiental "é um desencontro dos mortais com suas raízes" (1996, p.120);

ii) que provavelmente todas as pessoas têm um antepassado agricultor e

iii) "O ser humano, mais que um ser habitando na Terra ou no universo, é sobretudo uma dimensão da Terra e de fato do próprio universo" (Berry citado por Boff, 1996, p.44). Lembrando que denominações como: homens, humanos e humanidade têm origem na palavra latina "húmus" que quer dizer terra.

Uma proposição de Boff pode colaborar na formulação de respostas às questões anteriores, segundo ele o paradigma da modernidade "funcionava como uma membrana que impedia ver a presença de Deus. Ao romper este empecilho, o olho capta o que sempre estava aí presente: o gracioso advento da divindade e a possibilidade do extasiar-se humano" (1996, p.62). O autor continua sua interpretação dizendo que esta ruptura, que é também um momento de "re-ligação", pode se dar através de uma "experiência do sagrado" a qual se apresenta carregada de emoção, significado e valor.

Mas, como afirma este mesmo autor, quando se busca o entendimento desta situação de religação ao sagrado das coisas adentra-se o campo do "mistério" entendido não como o limite do conhecimento mas como o "ilimitado do conhecimento" (Boff, 1998, p.34).

\subsection{ENFRENTANDO AS QUESTÕES INICIAIS}

Conforme explicitado na Introdução, o pesquisador formulou uma serie de questões orientadoras para o estudo (Apêndice 1), porém o desenrolar dos trabalhos evidenciou a inadequação de algumas delas, obrigando a formulação de novas redações, seja para especificar, detalhar ou circunstanciar a avaliação ou, então, para imprimir uma perspectiva mais qualitativa às respostas. 
Outra observação preliminar, considerando inclusive um levantamento sucinto feito junto a diferentes atores, é quanto ao fato destas respostas sofrerem variações em função do referencial e dos objetivos de quem responde. Assim, se o respondente apoiar-se em parâmetros temporais de curta duração (meses ou poucos anos) e buscar a maximização da exploração dos recursos naturais e o aumento da produtividade específica, suas conclusões serão bem distintas das aqui apresentadas. Cabe lembrar que o presente estudo orienta-se no sentido de: "Estimular o questionamento do modelo agrícola convencional e a valorização de produtos e iniciativas agrícolas alternativas, visando a melhoria da qualidade de vida de produtores e consumidores agrícolas e a recuperação e sustentabilidade ambiental".

Devido às técnicas, aos procedimentos e às fontes empregadas, tais respostas podem ser classificadas em dois níveis de precisão. Um primeiro grupo de respostas caracteriza-se por uma grande precisão e especificidade do público enfocado, decorre do sistemático e longo acompanhamento da intervenção educacional promovida. Outro grupo apresenta respostas mais generalistas procurando abarcar o universo de educadores da rede de ensino, apoia-se em dados coletados de forma assistemática, sendo a confiabilidade das respostas bem menor que o primeiro grupo e sujeitas a grandes dificuldades de verificações conclusivas.

\section{- Q-1 Quais os principais conceitos, propostas e problemas referentes às relações entre agricultura e meio ambiente?}

A abordagem a partir da agroecologia reúne um conjunto de articulações entre conceitos e propostas, dentre as quais se destacam:

Leitura e interpretação da realidade rural a partir da noção de agro-eco-sistemas.

Valorização da biodiversidade.

Busca da sustentabilidade agro-sócio-ambiental.

Reconhecimento, resgate e integração do conhecimento e da cultura rural local.

Valorização da qualidade nutritiva e sanitária dos produtos agrícolas.

Valorização das potencialidades e produtos não agrícolas dos espaços rurais.

Quanto aos problemas sócio-ambientais relacionados ao atual modelo destacam-se: contaminações, degradação ambiental e esgotamento de recursos naturais (água, solo, fauna e flora), degradação da qualidade dos produtos agrícolas em especial dos alimentos (incluindo a perda de qualidade nutricional e efeitos dos contaminantes para saúde), redu- 
ção da biodiversidade inter e intra espécies, desqualificação da cultura e dos saberes tradicionais, aumento de custos operacionais e inviabilização econômica da atividade agrícola.

\section{- Q-2.1 Como o tema é tratado no ensino médio atualmente?}

Entre os educadores pesquisados constatou-se que a temática agro-ambiental era abordada quase exclusivamente nas disciplinas geografia e biologia. O enfoque assentavase em alguns poucos subtemas específicos como erosão dos solos; desmatamento para instalação de monoculturas e contaminações de águas, solos e alimentos. $A$ abordagem tinha um caráter genérico e teórico sem enfocar as condições locais e também sem articular e integrar os subtemas. As alternativas ao modelo agrícola atual não eram abordadas. Geralmente os professores apoiavam-se em informações apresentadas nos livros didáticos, ocasionalmente alguns recorriam a livros paradidáticos. Uma observação importante foi que no caso das escolas com grande número de estudantes agricultores ou filhos de agricultores, os professores tendiam a oferecer um tratamento ainda mais superficial.

Articulando os dados obtidos na intervenção com indicadores mais gerais levantados na pesquisa é possível supor que na grande maioria das escolas do estado de São Paulo, o quadro é o mesmo que o verificado junto ao grupo enfocado. Mesmo nas escolas técnicas agricolas, apenas muito recentemente o assunto passou a ser preocupação em algumas unidades, gerando ricas iniciativas, mas que ainda são pontuais.

\section{- Q-2.2 O que, como e quanto os educadores conheciam sobre o assunto?}

A pergunta inicial era: Qual o grau de conhecimento dos educadores sobre o assunto? Observou-se que entre os educadores pesquisados estes conhecimentos eram muito variáveis tanto em abrangência como em profundidade. Assim uma generalização pouco retrataria as condições reais.

A maioria dos pesquisados já possuía algum tipo de conhecimento relacionado às relações agro-ambientais em decorrência de cinco fatores principais:

- Histórico de vida pessoal relacionado à agricultura.

- Contato com educandos agricultores.

- Area de formação profissional. Verificou-se que geralmente geógrafos e biólogos tiveram algum contato acadêmico ou profissional com subtemas do assunto proposto.

- Interesse pela temática agrícola.

- Interesse pela temática ambiental. 
Baseados na experiência pessoal, em informações oferecidas por televisão, livros, mídia impressa e/ou por seus alunos agricultores, os conhecimentos dos educadores abarcavam, quase exclusivamente problemas ambientais e de saúde, tais como: contaminações do solo, água e alimentos; erosão; intoxicações, doenças de trabalho, acidentes e suicídios envolvendo agrotóxicos. Mas as interpretações destes problemas eram muito limitadas, sem identificarem articulações e contextualizações. Quase nenhum educador pesquisado possuia compreensão sobre aspectos históricos e políticos do atual modelo agrícola, sobre processos agro-ecológicos ou sobre propostas agrícolas alternativas. A exceção registrada abarcava alguns professores de geografia que tiveram contato com a temática através de um livro (Rosa, 1998) lido por constar da bibliografia de referência do Concurso Público para Rede de Ensino Estadual (SP) realizado em 1998.

Em síntese constatou-se que entre os educadores pesquisados a maioria tinha algum conhecimento pontual sobre o tema, alguns poucos apresentavam aprofundamento específico sobre determinados subtemas e pouquíssimos dominavam uma interpretação mais abrangente e integradora do assunto.

\section{- Q-2.3 Qual o grau de conhecimento dos educandos?}

Esta resposta será mais precisa se os educandos forem divididos em dois grupos:

Os estudantes que tinham relação direta com atividades agrícolas (agricultores ou parentes de agricultores) balizavam-se principalmente em suas experiências imediatas e em valores, discursos e referenciais decorrentes do modelo agrícola hegemônico, sendo seus conhecimentos muito variáveis conforme o subtema:

- em relação a problemas provocados por agroquímicos, em especial a contaminação dos alimentos e os riscos para saúde dos trabalhadores, foi observado que seus conhecimentos variavam entre médio e grande.

- quanto ao histórico da implantação da "revolução verde" e seus desdobramentos, os conhecimentos eram inexistentes ou muito pequenos.

- sobre os aspectos ecológicos e as propostas de agricultura alternativa identificouse dois padrões distintos: A grande maioria que se relacionava com a agricultura convencional pouco conhecia sobre o assunto, mas alguns que trabalhavam com agricultura alternativa demonstraram muitos conhecimentos sobre o tema.

Estudantes que não mantinham contato direto com atividades agrícolas apresenta- 
vam reduzidos conhecimentos sobre o assunto restringindo-se, quando muito, a listar problemas como erosão do solo e contaminação de alimentos.

\section{- Q 3.1 Como ampliar e melhorar a abordagem educacional do tema?}

A pesquisa possibilitou perceber que o enunciado acima é um problema e não exatamente uma questão passivel de obter respostas definitivas. A apresentação deste como pergunta associa-se a uma prepotência cientifista generalizadora articulada a uma interpretação reducionista do processo educativo.

A dificuldade começa pela falta de consenso sobre o que é educação e agrava-se com a complexidade e dinâmica especifica da abordagem educacional sobre as relações agro-ambientais. Percebe-se que não há uma única resposta, pois o que é válido para um determinado objetivo, contexto e/ou público pode não ser para outro. Para o enfrentamento das diversas interrogações que surgem a partir deste problema, o estudo indicou a necessidade do pesquisador e/ou do educador fazer algumas delimitações, tais como:

- Concepção e referenciais educacionais. Partindo das propostas em E.A. no presente trabalho Educação foi concebida, grosso modo, como meio e como processo de fortalecimento dos indivíduos e coletividades visando a formação de agentes co-autores dos seus destinos, da sociedade e do ambiente.

- Referenciais e objetivos sócio-políticos para o trabalho. No estudo foi adotado como referencial uma interpretação do Ambientalismo e como objetivos mais amplos a busca pela qualidade de vida, pela justiça social e pela sustentabilidade agro-sócio-ambiental.

- Público e região a ser envolvido no processo educativo.

No caso estudado, dois encaminhamentos se mostraram essenciais para melhorar $\mathrm{e}$ ampliar a abordagem do tema: promoção de estímulos para os educadores incorporarem a preocupação com o assunto e o fortalecimento dos educadores em sua capacidade de tratamento educacional e de enfrentamento do tema. Para tanto um procedimento altamente eficiente foi a realização de um curso de aperfeiçoamento.

- 3.2 Quais os conteúdos e subtemas agro-ambientais mais apropriados para abordagens em escolas?

A resposta anterior indica a necessidade do educador definir preliminarmente critérios para escolha dos conteúdos e subtemas de modo a contemplar os seus referenciais, os 
objetivos do processo, as peculiaridades dos seus alunos e as características regionais onde o trabalho insere-se. No caso estudado entre os critérios que se mostraram adequados aos trabalhos constaram:

- abordar temas que possibilitem articulações intra e inter disciplinas;

- considerar os interesses e necessidades dos educandos, o que incluiu o planejamento aberto e participativo da própria iniciativa educacional;

- apresentar os conceitos, procedimentos e outros aspectos avaliados como importantes pelo educador e ou apontados como relevantes por especialistas da área;

- considerar as capacidades do educador e eventuais colaboradores no enfrentamento das questões e situações problemas que podem surgir no tratamento do assunto.

Partindo dos resultados do caso estudado, de um levantamento bibliográfico junto a diversos autores e do entendimento de que o tema pode ser abordado em qualquer disciplina o pesquisador formulou uma relação de subtemas tidos como importantes no tratamento das relações agro-ambientais no ensino escolar:

- Histórico da modernização agrícola no mundo, destacando o processo e as conseqüências da Revolução Verde nos países subdesenvolvidos e no Brasil;

- Efeitos da modernização agrícola como: impactos agrícolas (aumento da produtividade e da produção, aumento da fragilidade dos cultivares); impactos ambientais (ao solo, à água, à biodiversidade, à fauna e flora,...); impactos sociais e outros;

- O excesso de produção articulado ao desperdício e à fome;

- Racionalidade hegemônica moderna e racionalidades alternativas;

- Limites e potencialidades dos saberes científicos e populares incluindo: resgate dos conhecimentos agrícolas populares e valorização dos conhecimentos científicos integralizadores como, por exemplo, a ecologia;

- Diagnóstico sócio-agro-ambiental local;

- Conceito de sustentabilidade e propostas ambientalistas;

- Noção de agro-eco-sistemas;

- Propostas alternativas para a relação agricultura e meio ambiente, incluindo a apresentação de iniciativas eficientes na busca pela agricultura sustentável;

- As propostas de engenharia genética - promessas, interesses e riscos. 
- Q 3.3 Como incluir o assunto na pauta da educação ambiental escolar?

O estudo indica que não se trata exatamente de inclusão, pois, alguns aspectos das relações agro-ambientais já são temas constantes em E.A. O que emerge como necessário é a promoção de um salto de qualidade que incorpore a abordagem das múltiplas interconexões inerentes ao tema e que estimule uma postura mais ativa dos educandos. Vários são os indicadores de que, para aumentar a possibilidade de sucesso desta empreitada, pelo menos três grandes frentes devem ser simultaneamente mobilizadas, de preferência através de políticas públicas integralizadoras: os educadores, o sistema de ensino e os órgãos governamentais dos setores agrícola e ambiental.

Uma necessidade é que as instâncias e órgãos governamentais estaduais e municipais (secretarias, universidades, instituições de pesquisa e de extensão rural) envolvidos com a temática, seja na perspectiva agrícola ou na ambiental, comprometam-se com o tratamento educacional do tema. Este compromisso pode ser traduzido em iniciativas como: organização de programas e estratégias de divulgação incluindo a produção de material básico de informação aos educadores, ao público em geral e à mídia; criação de canais de comunicação específicos entre as instituições e os educadores; assessoria técnica às instituições educacionais, mediação de contatos iniciais dos educadores com produtores alternativos, suas entidades (AAO, IBD, ...) e empresas comercializadoras.

Também é necessário que as estruturas estaduais e municipais de ensino assumam a temática, o que poderia ser feito principalmente através da promoção de eventos de divulgação e de cursos de aperfeiçoamento.

Uma iniciativa fundamental é ampliar o contato dos educadores com o assunto e posteriormente fortalece-los para enfrentarem educacionalmente a temática. Isto poderia ser feito através de:

- inclusão ou ampliação do tema nos cursos de licenciatura;

- promoção de cursos de formação continuada sobre o assunto;

- aumento da presença do tema em eventos de educação ambiental.

Algo que é imprescindivel, embora não exclusivo para a abordagem agro-ambiental á a melhoria das condições de trabalho oferecidas aos educadores. 
- Q 3.4 Como estimular os educadores a contribuírem para a expansão da agricultura sustentável? (estratégias)

Uma iniciativa que se mostrou extremamente pertinente foi a promoção de um processo de aperfeiçoamento de educadores sobre o assunto que, além de envolvê-los com a temática, buscou fortalece-los como educadores, através da melhoria da capacidade de promover junto aos seus educandos, a sensibilização, a incorporação, a mudança de comportamento e o fortalecimento das pessoas para enfrentamento das questões ambientais. Para isto foram promovidos procedimentos visando:

- Despertar a curiosidade e interesse pelo assunto;

- Envolver na temática aproveitando as dimensões racionais, sensoriais e emocionais;

- Envolver com o ambientalismo;

- Apresentar e/ou aprofundar sobre conceitos e propostas em E.A.;

- Resgatar e valorizar os conhecimentos e experiências dos participantes sobre agricultura e meio ambiente, relacionando-os e vinculando-os às novas informações;

- Estimular a pesquisa bibliográfica e de campo com destaque para a realização de diagnósticos agro-sócio-ambientais locais e regionais;

- Fornecer informações sobre o tema para construção de repertórios próprios;

- Criar "espaços/momentos" de problematização, estudos, diálogo, reflexão e enfrentamento de problemas relacionados à temática central.

- Apresentar e avaliar sistemas agrícolas alternativos através de visitas e tomada de depoimentos de produtores alternativos; apresentação de vídeos e disponibilização de material de imprensa.

- Colaborar na consolidação de equipes de educadores dispostos a trabalhar o assunto nas escolas.

- Q-3.5 Como estimular educandos no sentido de contribuírem para a expansão da agricultura sustentável?

- 3.6 Que posturas e práticas didático-pedagógicas podem contribuir para um processo educativo envolvendo o assunto que ultrapasse a mera transmissão de informações? 
Quanto à postura do educador a resposta assemelha-se àquela que provavelmente envolveria qualquer tema e pressupõem, entre outros, o compromisso com a temática e com o educando.

Entre as estratégias, quase tudo que se aplicou aos educadores (Questão Q 3.4) teve sucesso para estimular os educandos a contribuírem com a expansão da agricultura sustentável, podendo ser ressaltado:

- Despertar a curiosidade.

- Desvelar e exercitar habilidades.

- Resgatar os conhecimentos dos envolvidos sobre meio ambiente e agricultura.

- Promover a experimentação, a observação, a tomada de depoimentos e outras situações vivenciais, dentro e fora da sala de aula. Além de quebrar a rotina estes encaminhamentos aproximam os educandos das questões estudadas, despertam interesses, possibilitam o envolvimento, facilitam a compreensão, permitem o exercício de habilidades e estimulam mudanças de valores e atitudes.

- Estimular a realização de pesquisas sobre as condições agro-ambientais locais.

- Proporcionar o contato com sistemas agrícolas alternativos.

- Promover projetos multidisciplinares integrados à programação curricular da escola e que tenham horizontes temporais de médio prazo (pelo menos um semestre). Nestas bases foram propostos pelos educadores-cursistas 4 encaminhamentos, os quais reunidos constituem um rico leque de possibilidades:

E1 - Uma forma de colocar em pauta o assunto, estimular o enfrentamento prático do tema e demonstrar a validade das propostas orgânicas é através da instalação, manutenção e produção em uma horta orgânica na escola.

E2 - Uma abordagem articulando disponibilização de conhecimentos, incorporação de valores e execução de ações envolvendo temas como a valorização e o plantio de árvores, pode sensibilizar para as questões ambientais no geral e, indiretamente, para as relações agro-ambientais e até pode proporcionar situações de abordagem específica sobre este tema.

E3 - Dependendo da sensibilidade dos alunos diante dos temas sócio-ambientais, a temática agro-ambiental é inadequada, sendo recomendável o tratamento prévio 
de questões mais próximas ao cotidiano escolar como higiene dos alunos ou limpeza da escola, como forma de preparação e sensibilização para apresentação do tema.

E4 - No caso de público não envolvido diretamente com agricultura, a promoção de ações ambientais pode sensibilizar para as questões ambientais no geral e, indiretamente, contribuir para a formação de consumidores mais conscientes.

Como pode ser notado, as propostas E2, E3 e E4 associam-se à idéia de múltiplas portas de entrada para o ambientalismo, a qual pressupõem que ao se acessar algumas questões ambientalistas a pessoa torna-se mais aberta para outras demandas, que no caso seria as agro-ambientais.

Para o detalhamento de todos estes encaminhamentos é preciso avaliar o perfil dos educandos (produtor ou consumidor agrícola), a fim de estabelecer estratégias, temas e abordagens específicas.

No caso de trabalho educacional com educandos de perfil agrícola constatou-se a grande importância de valorizar os seus vínculos agrários e/ou rurais, incluindo o resgate de conhecimentos agrícolas tradicionais.

\section{- 3.7 Quais recursos didáticos podem ser utilizados para tratar o assunto?}

Os levantamentos apontaram uma carência de materiais didáticos sobre assunto. É quase inexistente os materiais que abordam o tema a partir de uma perspectiva agroecológica ou que apresentam as propostas alternativas de agricultura.

Em geral os livros didáticos tratam alguns poucos pontos e não procuram articular as dimensões agrícolas, ecológica e social.

Dos poucos livros paradidáticos sobre o tema disponíveis para o ensino fundamental e médio, a grande maioria também trata subtemas específicos e de modo desarticulado do contexto agro-sócio-ambiental.

Os materiais informativos (folhetos, boletins, cartilhas, etc.) e as publicações mais extensas (livros, manuais, revistas, etc.) das instituições de pesquisa e extensão rural, também não apresentam articulações agro-sócio-ambientais e podem ser reunidos em dois grupos:

- no primeiro grupo verifica-se materiais com uma abordagem especificamente agrí- 
cola e desarticulada da temática ambientalista. Geralmente associados ao modelo agrícola convencional estes materiais visam garantir o uso dos "insumos modernos" segundo o que é considerado adequado pelos fabricantes ou por outros setores comprometidos com o modelo (um exemplo é as campanhas pela triplice lavagem das embalagens de agroquímicos). Entre os subtemas usualmente presentes nestes materiais estão o uso de equipamentos de segurança para aplicação de agroquímicos, a conservação do solo, o não desperdício de água, a obediência ao receituário agronômico e outros.

- no segundo grupo estão materiais que apresentam discussões ecológicas clássicas, muitas vezes sem nenhum vínculo com as questões agro-ambientais. São comuns nestes materiais os temas: degradação flora, extinção da fauna, lixo, poluição e outros.

Um tipo de material que apresentou alta contribuição para abordagem sobre as relações agro-ambientais e principalmente sobre a viabilidade de propostas alternativas foram os suplementos de jornais e as revistas especializadas em agricultura. Contudo o "espaço" oferecido para o assunto nestes meios ainda é reduzido.

Os vídeos educacionais sobre o tema também são pouquíssimos, tendo sido encontrado apenas um que se destaca pela capacidade de disponibilizar informação, reter o interesse do espectador e atingir um amplo leque de público (desde crianças até técnicos agrícolas).

\section{- 3.8 Quais foram as dificuldades e empecilhos para abordagem do assunto?}

As dificuldades são de várias naturezas: dos educadores, das condições e das circunstâncias do sistema de ensino, do mérito do tema. Um conjunto de dificuldades diz respeito à inexistência de um domínio mínimo sobre o assunto entre quase todos os educadores. Este déficit de conhecimentos e experiências decorre, principalmente, da pequena disponibilização de informações sobre o assunto, da não abordagem nos cursos de graduação e da falta de cursos de atualização. No caso das escolas que contavam com grande número de alunos envolvidos com agricultura, a falta de domínio mínimo sobre o tema provocava uma insegurança nos educadores inibindo o tratamento do assunto.

Outro conjunto de problemas identificado diz respeito às dimensões estruturais e organizacionais das instituições educacionais e incluem: 
- Existência de uma grade horária que implica na falta de tempo da quase totalidade dos educadores para planejarem, acompanharem, avaliarem e refletirem sobre suas práticas. Geralmente os professores tinham uma carga horária que tomavam dois e até três períodos do dia, sendo que a maioria ainda enfrentava demandas domésticas e familiares.

- Falta de verbas para "capacitação" de educadores na Rede Estadual de Ensino.

- Em alguns casos verificaram-se dificuldades devido à falta de apoio da direção. Ocorre que a direção é fundamental em iniciativas que extrapolam a sala de aula ou que integram diferentes disciplinas.

Os problemas acima citados parecem associados à falta de uma verdadeira política pública de melhoria da qualidade de ensino que articule interesses e necessidades do público, melhore as condições de trabalho dos educadores e promova o aperfeiçoamento continuado dos educadores.

O terceiro conjunto de dificuldades decorre do mérito e do enfoque da temática e envolve as dimensões extra-escolares e extra-indivíduo.

Alguns problemas decorrem do assunto envolver questões cotidianas e até vitais para os educandos. O enfoque crítico adotado remete a um confronto com o discurso hegemônico da agricultura moderna e a defesa de propostas alternativas que ainda enfrentam muita resistência entre agricultores.

O estudo indicou que a abordagem escolar do assunto descontextualizada de iniciativas e políticas públicas voltadas à produção, à comercialização e ao consumo de produtos alternativos pode gerar um choque entre teoria (escolar) e prática (produção e consumo) e consequentemente um sentimento de frustração devido à dificuldade de mudança de hábitos relacionados ao tema.

Devido à condição de pobreza ou miséria de grande parte da população, a diferença de preços ao consumidor entre produtos agrícolas convencionais e alternativos torna-se um fator de desestímulo para a abordagem escolar do tema.

Um outro inibidor da abordagem agro-ambiental, em alguns casos, é a pressão de pais e diretores das escolas a favor de um ensino voltado intensamente para o vestibular. 
- Q 4.1 Quais as conseqüências que a intervenção visando a ampliação do tratamento do tema no ensino médio provocou nos sujeitos diretamente envolvidos?

- Q 4.2 Quais as conseqüências que a ampliação do tratamento do tema no ensino médio provocou nas comunidades?

- Q 4.5 A ampliação de conhecimento sobre o assunto gerou alguma influência mais duradoura nos professores, nos alunos ou em suas comunidades? Quais?

As perguntas inicialmente formuladas (Apêndice 1) possuíam uma intenção de prospecção de potencialidades o que é extremamente difícil e provavelmente exigiria a construção de uma teoria. Foram então alteradas no sentido de abordarem o caso enfocado. Mesmo assim deve-se considerar a grande dificuldade de mensuração e avaliação de impactos de processos educativos.

A formulação destas respostas sofre com a dificuldade de avaliação dos resultados de processos educativos. Apesar disto, pode-se apontar que no caso estudado houve muitas repercussões como a construção de novas percepções; a ampliação das preocupações ambientalistas; a valorização do trabalho agrícola; a assimilação de preocupações específicas sobre impactos ambientais na agricultura, mudanças comportamentais dos envolvidos tanto na escola como em casa, mudanças de hábitos de consumo, manifestações de aumento da auto estima dos professores e dos alunos e melhoria das relações interpessoais nas escolas (entre alunos e entre estes e os professores).

Quanto aos educadores-cursistas quase todos assumiram a preocupação com dimensão ambiental na agricultura, passando a inclui-la em suas programações disciplinares. Além disso, muitos professores estão aproveitando ou criando oportunidades extracurriculares para colocar o tema em pauta junto aos seus alunos. No âmbito pessoal quase todos incorporaram preocupações e cuidados com produtos agrícolas in natura.

No caso dos estudantes as reações foram muito variáveis. Entre aqueles que trabaIharam diretamente com o projeto horta orgânica foi possivel identificar o crescimento da preocupação com as questões ambientais na agricultura, a valorização do trabalho e dos conhecimentos rurais, o aumento da auto-estima e da participação dos estudantes agricultores ou filhos de agricultores.

A incisiva postura propositiva dos educadores repercutiu na comunidade extraescolar e gerou várias influências tais como: 
- Fortalecimento da agricultura orgânica diante do secretário de agricultura municipal.

- Realização por parte do sindicato dos produtores rurais de um curso sobre agricultura orgânica.

- Contribuição em decisões de alguns produtores quanto a conversão de modos de produção de convencional para orgânico.

- Engajamento de alguns pais em atividades da escola

- Montagens de hortas orgânicas em outras escolas da região.

- Q 4.3/ Q 4.4 O assunto desperta interesses e motivações nos educadores e educandos?

Quanto ao interesse os dados indicaram que o mais adequado é dizer que o tema mobiliza e reforça interesses pré-existentes sobre agricultura e ou sobre meio ambiente. Destaca-se a tendência de grande interesse e motivação dos estudantes que possuem vínculos com a agricultura.

Já em relação ao processo junto aos estudantes verificou-se uma tendência de crescimento da motivação em função da sinergia criada pelo reforço de interesses préexistentes e a aplicação de procedimentos educacionais pró-ativos.

Em que intensidade o ensino do assunto sugerido contribuiu para:

- Q 4.8 incentivar posturas mais participativas diante do assunto?

- Q 4.9 aumentar o questionamento do atual modelo agrícola?

- Q 4.10 influir na conscientização sobre as possibilidades de adoção de modelos agrícolas alternativos?

O estudo apontou a grande dificuldade de identificar, de mensurar e de generalizar estas avaliações na medida que são extremamente variáveis de indivíduo para indivíduo. Por exemplo, é impossivel dimensionar quantos pessoas foram influenciadas pela exposição das escolas durante a Exposição Agro-industrial da cidade. Neste sentido houve o registro do caso de um agricultor que declarou que a exposição da escola foi o elemento consolidador de sua decisão em modificar o seu padrão de produção de convencional para orgânico.

Os dados também indicaram que a intensidade das contribuições de tal processo 
educativo dependerá principalmente dos objetivos, do enfoque, das estratégias/procedimentos e dos interesses dos envolvidos (educadores e educandos).

A capacidade de influência de processos educativos em incentivar o questionamento e superação do modelo agrícola convencional foi avaliada como grande, principalmente quando articulou a crítica ao modelo agrícola atual com a apresentação de propostas alternativas viáveis. 


\section{CONCLUSÕES}

Entre os educadores enfocados a abordagem na escola sobre relações agroambientais, era muito deficiente, superficial e de enfoque pontual. Sendo que no caso de educadores que trabalham com alunos que se relacionam com agricultura detectou-se a tendência a um tratamento ainda mais superficial.

Os educadores enfrentavam diversos problemas com o tema tais como: não abordagem na formação inicial, quase inexistência de cursos de atualização e/ou aperfeiçoamento, carência de material de apoio, falta de divulgação nos meios de informação de massa e em eventos para educadores. Também foram agregados indícios que sinalizam a possibilidade de generalização do mesmo diagnóstico em relação aos educadores do estado de São Paulo em geral.

As três áreas governamentais que se relacionam com o assunto (a saber: agricultura, meio ambiente e educação) e atuam no estado de São Paulo apresentam pouquíssimas iniciativas voltadas ao tratamento do assunto e menos ainda na abordagem proposta pelo presente trabalho.

Considerando que se trata de construir uma cultura/racionalidade da sustentabilidade, o que exige novos olhares, valores, compreensões, saberes, competências e habilidades. No trabalho ficou evidente a necessidade e a importância de processos educativos voltados ao fortalecimento das pessoas em suas dimensões cognitiva, interior e social. Os princípios e procedimentos associados à educação ambiental ofereceram uma grande contribuição para melhorar a abordagem educacional das relações agro-ambientais entre os envolvidos. Neste contexto foi fundamental o contato dos educandos com iniciativas e com empreendedores de alternativas agrícola viáveis. No estudo também se destacou a grande contribuição que processos de aperfeiçoamento de educadores podem oferecer no sentido do objetivo em questão.

Outra observação foi que o contato dos educadores com o assunto e o seu trata- 
mento junto aos educandos pode ser uma importante e efetiva "porta de entrada" para o ambientalismo e para E.A. nas escolas, principalmente em regiões em que a população tem vínculos com a produção agrícola.

$\mathrm{Na}$ abordagem do tema foram também identificados vários problemas relacionados aos educadores, ao sistema de ensino e às particularidades do tema.

A crítica ao modelo convencional de agricultura e a defesa de propostas alternativas enfrenta muitos obstáculos sociais, econômicos, culturais, políticos, etc. implicando em uma grande dificuldade para os processos educativos que adotam este enfoque. Assim a abordagem do assunto no ensino regular é essencial para a construção de uma cultura de sustentabilidade agro-sócio-ambiental, mas insuficiente para estimular transformações na produção e no consumo de produtos agrícolas e terá sucesso restrito se não for empreendida em conjunto com outras iniciativas que possibilitem um enfrentamento sistêmico da questão.

Uma importantíssima observação é o fato da E.A. e seus referenciais ainda serem pouco conhecidos e incorporados pelos educadores. Num quadro em que é forte a ânsia por superar o modelo e a estrutura educacional hegemônica, a estratégia de "resolução de problemas" deixa de ser tomada como meio/ferramenta em processos educativos para se tornar fim em si. Os educadores tendem a considerar a E.A. mais como um recurso operatório no enfrentamento de questões ambientais do que uma perspectiva educacional, implicando em propostas centradas na promoção de ações ou na resolução de problemas e pouco na formação dos educandos. Muitas vezes os educadores baseando-se em diagnósticos simplificadores e abordagens sócio-políticas ingênuas, tendem a propor e promover atividades pontuais, desarticuladas e incapazes de enfrentar os problemas abordados.

Apesar dos esforços, da boa vontade e do grande desgaste que gera nos envolvidos, estas iniciativas não conseguem nem dar conta das questões ambientais tratadas e nem aumentar a eficiência nos processos educativos, pouco contribuindo para a formação do educando como um agente enfrentador de problemas ambientais. O comportamento citado parece inserir-se em problemas mais amplos como a deficiência na difusão da educação ambiental e, principalmente, a estreita concepção de educação apresentada por muitos educadores.

Após dois anos acompanhando um grupo de mais de 50 educadores e considerando diversas outras fontes, torna-se necessário apontar que na atualidade o estímulo e a moti- 
vação dos educadores não só para abordar a temática agro-ambiental, mas para todo o seu trabalho, sem desqualificar outras iniciativas, depende muito mais do resgate, da revalorização ou mesmo de uma nova construção para a função e para a profissão do educador assim como de uma reestruturação do sistema de ensino a fim de oferecer condições efetivas ao exercício da atividade educacional.

Para finalizar este texto e estimular outros estudos, o pesquisador optou por lembrar as palavras de uma educadora que trata do impacto emocionante, generalizado, profundo e contundente provocado pelas atividades de manipulação de terra e de plantas junto a uma comunidade escolar, mas que também poderia ser parte da justificativa da busca pela sustentabilidade sócio-ambiental da agricultura.

"o manuseio da terra parece ativar sentimentos positivos e estimular o equilibrio entre os envolvidos" ... "há uma força que vem da terra, que age no ser humano, mudando o comportamento (...) e integrando as pessoas" (Profa . Sara, Anotações de campo 27/10/99). 
116 


\section{REFERÊNCIAS BIBLIOGRÁFICAS}

ALMEIDA, S.G. A agricultura alternativa em construção. Revista Alternativas -Cadernos de Agroecologia, v.1, p.1-6, 1991.

ALTIERE, M.A. Agroecologia: as bases cientificas da agricultura alternativa. Trad. de P. Vaz. Rio de Janeiro: PTAJFASE, 1989. 240 p.

ALVES-MAZZOTTI , A.J. O método nas ciências naturais e sociais: pesquisa quantitativa e qualitativa. São Paulo: Ed. Pioneira, 1998. 1v.

ARDOINO, J. Abordagem multirreferencial (plural) das situações educativa e formativas. In: BARBOSA, J.G. (Coord.) Multirreferencialidade nas ciências e na educação. São Carlos: Edufscar, 1998. cap.1, p. 24-41.

ARDOINO, J. Entrevista com Cornelius Castoriadis. In: BARBOSA, J.G. (Coord.) Multirreferencialidade nas ciências e na educação. São Carlos: Edufscar, 1998. cap.3, p.50-72.

BARBIER, R. A escuta sensivel na abordagem transversal. In: BARBOSA, J.G. (Coord.) Multirreferencialidade nas ciências e na educação. São Carlos: Edufscar, 1998. cap. 12, p. $168-199$.

BARBOSA, J.G. Educação para a formação de autores-cidadãos. In: BARBOSA, J.G. (Coord.) Multirreferencialidade nas ciências e na educação. São Carlos: Edufscar, 1998a. cap. 1, p. 7-13.

BARBOSA, J.G. (Org.) Reflexões em torno da abordagem multirreferencial. São Carlos: Edufscar, 1998b. 126p.

BÁRCENA, A. Cidadania Ambiental. In.:GUTIÉRREZ, F.; PRADO, C. Ecopedagogia e cidadania planetária. São Paulo: Cortez - Instituto Paulo Freire, 1999. p.13-19.

BOFF, L. O despertar da águia: o dia-bólico e sim-bólico na construção da realidade. Petrópolis: Ed. Vozes, 1998. p.174. 
BOFF, L. Ecologia, mundialização e espiritualidade. São Paulo: Ed.Ática, 1996. 180p.

BRANDÃO, C.R. O Ambiente, o Sentimento e o Pensamento: Dez Rascunhos de Idéias.

In: FÓRUM DE EDUCAÇÃO AMBIENTAL, 4. / ENCONTRO DA REDE BRASILEIRA DE EDUCAÇÃO AMBIENTAL, 1., Guarapari, 1997. Cadernos. Rio de Janeiro: INESC, 1997. p.17-38.

BRANDÃO, C.R. Repensando a Pesquisa Participante. São Paulo: Ed. Brasiliense, 1984. 160p.

BRANDÃO, C.R. Pesquisa Participante. 6.ed. São Paulo: Ed. Brasiliense, 1982. 128p.

BRASIL. MEC/Ministério de Educação.- Referenciais para formação de Professores. Brasilia: Secretaria de Educação Fundamental, 1999. 177p.

BURNHAM, T.F. Complexidade, multirreferencialidade, subjetividade: três referências. In: BARBOSA, J.G. (Org.) Reflexões em torno da abordagem multirreferencial. São Carlos: Edufscar, 1998. cap.3, p.35-55.

CANDAU, V.M.F. Formação Continuada de Professores. In: REALI, A.M.M.R.; MIZUKAMI, M.G.N. Formação Continuada de Professores: tendências atuais. São Carlos: Edufscar, 1996. cap.9, p.140-152.

CARVALHO, I.C.M. Em direção ao mundo da vida: interdisciplinaridade e educação ambiental. Brasilia: IPÊ-Instituto de Pesquisas Ecológicas, 1998. 101p.

CARVALHO, L.M. Educação Ambiental e a Formação de Professores. In: BRASIL MINISTÉRIO DA EDUCAÇÃO. Oficina Panorama de Educação Ambiental no Brasil. Brasilia: MEC, 2000. 1v.

COLON, A. Etnometodologia e multirreferencialidade. In: BARBOSA, J.G. (Coord.) Multirreferencialidade nas ciências e na educação. São Carlos: Edufscar, 1998. cap.10, p 149-158.

COMERFORD, J.C.; GRZYBOWSKI, L.M. (Trad.) Agricultura Sustentável. Rio de Janeiro: AS-PTA, 1992. 44p.

CZAPSKI, S. A Implantação da Educação Ambiental no Brasil. Coordenação de Educação Ambiental do Ministério da.Educação e do Desporto. Brasilia: MEC, 1998. 166p.

DELORS, J. Educação um tesouro a descobrir. 4 ed. São Paulo: Cortez; Brasilia: MEC/UNESCO, 2000. 288p. 
DEMO, P. Pesquisa e Construção de Conhecimento - Metodologia científica no caminho de Habermas. Rio de Janeiro: Tempo Brasileiro, 1994. 125p.

DEMO, P. Pesquisa: Princípio cientifico e educativo. 5.ed. São Paulo: Cortez, 1997. 120p.

DEMO, P. Educar pela pesquisa. 3.ed. Campinas: Autores Associados, 1998. 129p.

DIAS, G.F. Educação Ambiental: princípios e práticas. São Paulo: Ed. Gaia, 1992. 399p.

DIEGUES, A.C.S. Desenvolvimento Sustentável ou Sociedades Sustentáveis: da crítica dos modelos aos novos paradigmas. Revista São Paulo em Perspectiva, v.6, n.1/2, p.2229, 1992.

EHLERS, E. Agricultura sustentável: origem e perspectiva de um novo paradigma. São Paulo: Livros da Terra Editora, 1996. p.178.

EVERS, T. A face oculta dos novos movimentos sociais. Revista Novos Estudos Cebrap, v.2, p.4-40, 1984.

FAZENDA, I.C.A. (Org.) Práticas interdisciplinares na escola. 4.ed. São Paulo: Cortez, 1997. p.159.

FAZENDA, I.C.A. Estudos e Pesquisas sobre Interdisciplinaridade. / Apresentado ao Congresso Internacional de Formação de Professores nos Paises de Língua e Expressão Portuguesas, Aveiro, 1993/

FIGUEIREDO, L.A.V.; SILVA, L.A. (Re)Descobrir o prazer de ensinar e aprender: In: FÓRUM DE EDUCAÇÃO AMBIENTAL, 4. / ENCONTRO DA REDE BRASILEIRA DE EDUCAÇÃO AMBIENTAL, 1., Guarapari, 1997. Cadernos. Rio de Janeiro: INESC, 1997. p.94-106.

FÓRUM DE ONGs BRASILEIRAS, 1, Rio de Janeiro, 1992. Meio ambiente e desenvolvimento: uma visão das ONGs e dos movimentos sociais brasileiros. Rio de Janeiro: Fórum de ONGs Brasileiras, 1992. 190p.

FÕRUM INTERNACIONAL DE ONGs E MOVIMENTOS SOCIAIS, 1., Rio de Janeiro, 1992. Tratado das ONGs. Santos: Fórum Internacional de ONGs e Movimentos Sociais / Fórum Brasileiro de ONGs e Movimentos Sociais para o Meio Ambiente e Desenvolvimento, 1992 . $294 p$.

GADOTTI, M. Cidadania Planetária. In.:GUTIÉRREZ, F.; PRADO, C. Ecopedagogia e cidadania planetária. São Paulo: Cortez/Inst. Paulo Freire, 1999. cap.2, p.21-25. 
GLIESSMAN, S.R. Agroecologia: processos ecológicos em agricultura sustentável. Porto Alegre: Ed. Universidade/UFRGS, 2000. 653p.

GONÇALVES, C.W.P. Os (des)caminhos do meio ambiente. São Paulo: Contexto, 1990. $148 p$.

GRAZIANO NETO, F. Questão agrária e ecologia, crítica da moderna agricultura. São Paulo: Brasiliense, 1986. 154p.

GUIVANT, J.S. Parâmetros teóricos para análise da difusão e adoção de uma agricultura sustentável. In: VIEIRA, P.F.; MAIOMON, D. (Orgs.). As Ciências Sociais e a questão ambiental. Belém: APED/NAEA, 1993. cap.7, p.121-139.

GUTIÉRREZ, F.; PRADO, C. Ecopedagogia e cidadania planetária. São Paulo: Cortez/ Instituto Paulo Freire, 1999. 128p.

HECKLER, E.S.B.; EGONR, M. Dicionário da Língua Portuguesa. São Leopoldo: Unisinos, 1984. $2175 p$.

HERNÁNDEZ, F. Transgressão e mudança na educação: os projetos de trabalho. Porto Alegre: ArtMed, 1998. 150p.

LAPASSADE, G. Da multirreferencialidade como 'bricolagem'. In: BARBOSA, J.G. (Coord.) Multirreferencialidade nas ciências e na educação. São Carlos: Edufscar, 1998. cap.9, p.126-148.

LEIS, H. (Org.). O labirinto: ensaios sobre ambientalismo e globalização. FURB/Gaia. São Paulo, 1996. 174p.

LÜDKE, M.; ANDRÉ, M.E.D.A. Pesquisa em educação: abordagens qualitativas. São Paulo: EPU, 1986. 100p.

MACEDO, R.S. Por uma epistemologia multirreferencial e complexa dos meios educacionais. In: BARBOSA, J.G. (Org.) Reflexões em torno da abordagem multirreferencial. São Carlos: Edufscar, 1998. cap.4, p.57-71.

MARTINS, J.B. Multirreferencialidade e educação. In: BARBOSA, J.G. (Org.) Reflexões em torno da abordagem multirreferencial. São Carlos: Edufscar, 1998. cap.2, p.2134

McCORMICK, J. Rumo ao paraíso: a história do movimento ambientalista. Rio de Janeiro: Ed. Relume-Dumará, 1992. 222p. 
MEDINA, N.M. Elementos para a introdução da dimensão ambiental na educação escolar. In.: IBAMA. Amazônia: uma proposta interdisciplinar de educação ambiental. Brasília: IBAMA, 1994. cap.1, p.5-72.

MORIN, E. O problema epistemológico da complexidade. Lisboa: Europa-América, 1984. 1v.

MORIN, E. Ciência com Consciência. Rio de Janeiro: Bertrand Brasil, 1996. 344p.

MORIN, E. A cabeça bem-feita. Rio de Janeiro: Bertrand Brasil, 2000. 128p.

MUÑOZ, M.C.G. Principales tendencias y modelos de la Educación Ambiental en el sistema escolar. Revista Iberoamericana de Educacion, v.11, p.13-74, mayo/ago. 1996.

NEPAM. Guia para Elaboração de Propostas (apostila). Campinas: NEPAM/UNICAMP, 1992. 51p.

NOVO, M. La Educación Ambiental formal e no formal: dos sistemas complementarios. Revista Iberoamericana de Educacion, v.11, p.75-102, mayo/ago. 1996.

PAGĖS, M. A análise dialética: proposições. In: BARBOSA, J.G. (Coord.) Multirreferencialidade nas ciências e na educação. São Carlos: Edufscar, 1998. cap.5, p.73-84.

PASCHOAL, A.D. Pragas, praguicidas e a crise ambiental: problemas e soluções. Rio de Janeiro: FGV, 1979. 210p.

PENTEADO, H.D. Meio ambiente e formação de professores. São Paulo: Cortez Ed., 1994. 120p.

PRIMAVESI, A.M. Agricultura sustentável. São Paulo: Livraria Nobel, 1992. 142p.

REIGOTA, M. Desafios à educação ambiental escolar. In: SÃO PAULO (Estado). Educação, Meio Ambiente e Cidadania. São Paulo: SMAVCEAM, 1998. cap.7, p.43-50.

ROSA, A.V. Agricultura e meio ambiente. São Paulo: Atual Editora, 1998. 94p.

SANTOS, B.S. Pela Mão de Alice - O social e o político na pós-modernidade. 3.ed. São Paulo: Cortez Editora, 1997. 348p.

SANTOS, B.S. Introdução a uma ciência pós-moderna. Rio de Janeiro: Graal, 1989. 176p.

SATO, M. Formação em Educação Ambiental - da escola à comunidade. In: BRASIL MINISTÉRIO DA EDUCAÇÃO. Oficina Panorama de Educação Ambiental no Brasil. Brasília: MEC, 2000. 1v. 
SEGURA, D.S.B. Venturas e Desventuras da Educação Ambiental na Escola Pública: um estudo de experiências. São Paulo, 1999. 202p. Dissertação (Mestrado) - Faculdade de Educação, Universidade de São Paulo.

SORRENTINO, M. Educação Ambiental: avaliação de experiências recentes e suas perspectivas. In: PAGNOCCHESCHI, B. (Coord.) Educação Ambiental: experiências e perspectivas. Brasília: INEP, 1993. cap.1, p. 7-30.

SORRENTINO, M. Educação Ambiental e Universidade: Um Estudo de Caso. São Paulo, 1996. 1v. Tese (Doutorado). Faculdade de Psicologia, Universidade de São Paulo.

TASSARA, E.T.O. Globalização, paradigmas e utopias: questões de método na pesquisa social contemporânea. Coletâneas ANPEPP. v. 1, n. 13, p.83-95, set. 1996.

TASSARA, E.T.O. Educação Ambiental, Referenciais Históricos, Teóricos e Formação de Redes. In: FÓRUM DE EDUCAÇÃO AMBIENTAL, 4. I ENCONTRO DA REDE BRASILEIRA DE EDUCAÇÃO AMBIENTAL, 1., Guarapari, 1997. Cadernos. Rio de Janeiro: INESC, 1997. p.39-51.

TASSARA, E.T.O; Damergian, S. Para um novo humanismo: contribuições da Psicologia Social. Revista de Estudos Avançados, v.10, n.28, p.291-316, 1996.

THIOLLENT, M. Notas para o debate sobre pesquisa-ação. In: BRANDÃO, C.R. Repensando a Pesquisa Participante. São Paulo: Ed. Brasiliense, 1984. cap.5, p.82-103.

THIOLLENT, M. Metodologia da Pesquisa-Ação. São Paulo: Cortez e Autores Assoc., 1985. 1v.

VASCONCELLOS, C.S. Planejamento: Projeto de Ensino-Aprendizagem e Projetos Político-Pedagógicos. São Paulo: Libertad, 1999. 205 p.

VASCONCELLOS, H.S.R. A pesquisa-ação em projetos de educação ambiental. In: PEDRINI, A.G. (Org.) Educação Ambiental: reflexões e práticas contemporâneas. Petrópolis: Ed. Vozes, 1997. cap. 11. p.260-271.

VIVAN, J.L. Agricultura e Florestas: Princípios de uma interação vital. Guaíba: Agropecuária, 1998. 207p.

VIOLA, E. A dinâmica do ambientalismo e o processo de globalização. São Paulo em Perspectiva. v.1/2, p.6-12, 1992. 
APÊNDICES 

APÊNDICE 1 - FRAGMENTOS DO PROJETO DE PESQUISA INICIAL FL. 1 de 4

(VERSÃO APRESENTADA À FAPESP E AO DPTO. CIÊNCIAS FLORESTAIS EM SET/1998)

Projeto de pesquisa para mestrado.

\section{DESENVOLVIMENTO PARTICIPATIVO DE PROPOSTAS DE ABORDAGENS SOBRE AS RELACÕES ENTRE AGRICULTURA E MEIO AMBIENTE, NO ÂMBITO DO ENSINO MÉDIO, ATRAVÉS DA EDUCACÃO AMBIENTAL}

(...)

\section{OBJETIVOS}

- O objetivo mais amplo do trabalho é contribuir para a melhoria do processo educativo sobre as relações entre agricultura e meio ambiente através de uma educação ambiental, que incentive a reflexão, exercite a discussão e aumente os conhecimentos dos envolvidos, possibilitando a forma-ção de uma consciência critica sobre o assunto e o questionamento modelo agrícola convencional.

Segundo Thiollent ao se detalhar a pesquisa-ação é necessário identificar os objetivos práticos e os objetivos teóricos (relacionados à construção do conhecimento) do trabalho, assim temos que:

- O objetivo prático da proposta é introduzir ou aprimorar a abordagem do assunto no âmbito do ensino médio e na perspectiva da educação ambiental, através da promoção de um "curso-oficina de atualização e capacitação de professores" (detalhado nas páginas seguintes).

- Quanto aos objetivos teóricos as principais metas são:

a)- Realizar um diagnóstico sucinto sobre o ensino das relações entre agricultura e meio ambiente em escolas do ensino médio;

b)- Avaliar o grau de interesse, motivações, limitações e dificuldades dos professores e de seus alunos num processo de ensino-aprendizagem envolvendo o tema;

c)- Discutir sobre a contribuição que o ensino do assunto pode oferecer para formação de um posicionamento crítico diante das questões sócio-ambientais e para incentivar mudanças de práticas e comportamentos, especialmente os associados à produção e ao consumo agrícola;

d)- Avaliar o processo de preparação e execução do curso-oficina, inclusive quanto as vantagens e desvantagens deste no contexto da pesquisa-ação;

e)- Identificar possiveis desdobramentos decorrentes do curso.

Espera-se também que o trabalho ofereça uma pequena contribuição para a melhoria da qualidade de ensino na rede pública de nivel médio, através de alguns ganhos para os professores envolvidos, tais como: vivência na programação e execução de projetos de educação ambiental; reconhecimento e valorização da produção didática própria; percepção das possibilidades de conteúdos, princípios e procedimentos didáticos-pedagógicos relacionadas à educação ambiental; aumento de experiência em atividades coletivas e multidis-ciplinares; troca de experiências entre os professores; contato com o método da pesquisa-ação e outros.

\section{(...)}

Formulação do problema

O trabalho busca indicativos de respostas para três conjuntos de questões:

- Como o tema: "relações entre agricultura e meio ambiente" é tratado no ensino médio atualmente?

- Como ampliar e melhorar a abordagem do tema no ensino médio?

- Quais as conseqüências que esta ampliação pode provocar nos sujeitos envolvidos no projeto e eventualmente em suas comunidades?

Estas questões podem ser desdobradas em muitas outras, remetendo a problemas práticos (centrados na execução da ação proposta) e teóricos (associados à construção do conhecimento), do quais se destacam:

- 1.1 Quais os principais conceitos quanto às relaçoes entre agricultura e meio ambiente?

- 1.2 Quais as principais propostas quanto às relaçoes entre agricultura e meio ambiente?

- 1.3 Quais as principais questões quanto às relaçoes entre agricultura e meio ambiente?

- 2.1 Como o tema: é tratado no ensino médio atualmente?

- 2.2 Qual o grau de conhecimento dos educadores ?

- 2.3 Qual o grau de conhecimento dos educandos ? 


\section{APÊNDICE 1 - FRAGMENTOS DO PROJETO DE PESQUISA INICIAL FL. 2 de 4}

Quanto ao tratamento no ensino médio das: "relaçoes entre agricultura e meio ambiente":

- 3.1 Como ampliar e melhorar a abordagem do tema?

- 3.2 Quais os conteúdos e sub-temas mais apropriados ?

- 3.3 Como incluir o assunto na pauta da educação ambiental?

- 3.4 Como estimular educadores no sentido de contribuírem p/ a expansão da agricultura sustentável?

- 3.5 Como estimular educandos no sentido de contribuírem p/ a expansão da agricultura sustentável?

- 3.6 Quais as posturas e práticas didático-pedagógicas que podem contribuir para um processo educativo envolvendo o assunto que ultrapasse a mera transmissão de informaçöes?

- 3.7 Quais recursos didáticos podem ser utilizados para tratar este assunto

- 3.8 Quais as dificuldades e empecilhos para abordagem do assunto?

- 4.1 Quais as conseqüências que a ampliação do tratamento do tema no ensino médio pode provocar nos envolvidos?

- 4.2 Quais as conseqüências que a ampliação do tratamento do tema no ensino médio pode provocar nas comunidades?

- 4.30 assunto desperta interesses e motivações nos educadores?

- $4.4 \mathrm{O}$ assunto desperta interesses e motivaçöes nos educandos ?

- 4.5 A ampliação de conhecimento sobre o assunto pode gerar alguma influência mais duradoura nos professores, nos alunos ou em suas comunidades? Quais

Em que intensidade o ensino do assunto sugerido pode contribuir para:

- 4.8 incentivar posturas mais participativas diante do assunto?

- 4.9 aumentar o questionamento do atual modelo agrícola?

- 4.10 influir na conscientização sobre as possibilidades de adoção de modelos agricolas alternativos?

\section{(...)}

\section{PLANO DE TRABALHOE PROCEDIMENTOS}

1 Pesquisa e revisão bibliográfica abarcando: a) tópicos e conteúdos sobre o tema: agricultura e meio ambiente; b) educação formal em especial o ensino médio; c) principios e propostas em educação ambiental.

2 Levantamento, diagnóstico e avaliação sucinta dos conteúdos, materiais didáticos, abordagens e procedimentos pedagógicos utilizados ao tratar o tema em:

a) Escolas de nível médio da rede pública. Método: entrevistas com professores e levantamento em livros didáticos.

b) Organizações não escolares: redes e entidades de educação ambiental, redes e entidades ligadas à agricultura alternativa, universidades e órgãos governamentais de pesquisa e de extensão rural. Método: revisão bibliográfica e pesquisa junto às entidades.

3 Confeç̧ão de materiais informativos (apostila, slides, transparências e outros) contendo uma síntese dos principios, sub-temas e questões que compõem o assunto.

$4 \quad$ Organização e preparação do curso-oficina, incluindo aspectos como: contatos e acordos com os parceiros na pesquisa (Prefeituras, Delegacia de Ensino, escolas e outros); trâmites burocráticos (Universi-dade e Secretaria de Educação) e planejamento das atividades.

5 Formulação do questionário Q1 (a ser respondido pelos professores participantes do curso) e da proposta para discussão do questionário QA1 (a ser aplicado aos alunos daqueles professores).

6 Visando adiantar algumas atividades, aproveitar a experiência de organização do curso, resgatar as pesquisas bibliográficas e sistematizar o trabalho já desenvolvido, será iniciado o rascunho da dissertação.

7 Seminário com os pesquisadores observadores (S1) para discutir a proposta do curso e o andamento da pesquisa.

8 O início do curso-oficina está previsto para janeiro de 1999 conforme a programação preliminar que consta no

Anexo I deste projeto. Geralmente as aulas ocorrerão aos sábados e terão duração de 4 horas, mas há algumas exceções em função da atividade ou dinâmica de trabalho.

9 Durante o Módulo 1 do curso o pesquisador e os participantes discutirão e definirão o encaminha-mento do curso quanto a aspectos como: dinâmica de trabalho, sub-temas a serem abordados, propostas de pesquisas e projetos, materiais a serem produzidos, temas para as oficinas, atividades de campo e outros.

10 Ao final do Módulo 1 será realizado um seminário com os pesquisadores observadores (S2) visando: a) apresentar as impressöes sobre o desenvolvimento do curso; -b) apresentar a proposta coletiva de andamento do curso e -c) discutir o desenrolar da pesquisa. Dependendo do interesse e da disponibilidade os professores integrantes do 


\section{APÊNDICE 1 - FRAGMENTOS DO PROJETO DE PESQUISA INICIAL FL. 3 de 4}

curso serão convidados a participarem deste e dos demais seminários programados.

11 No transcorrer dos módulos 2 e 3 do curso, o pesquisador reservará alguns dias para acompanhar, observar e registrar as atividades extra-classe desenvolvidas pelos participantes, se necessário colaborando e subsidiando as pesquisa, a produção de materiais didáticos e a confeç̧ão de projetos didáticos-pedagógicos.

12 Durante o Módulo 4 o pesquisador irá acompanhar e registrar a "aplicação" dos conhecimentos, materiais e projetos desenvolvidos no curso.

13 Preparação e aplicação dos questionários "Q2" junto aos participantes do curso.

14 Seminário com os pesquisadores observadores (S3) para apresentar e discutir as impressões, resultados e avaliações preliminares sobre o curso e a pesquisa.

15 Análises dos registros, questionários e avaliações do transcorrer do curso.

16 Qualificação.

17 Aprofundamento das análises e elaboração de uma sintese das observações, avaliações, questionários e considerações da pesquisa.

18 Aplicação e avaliação dos questionários "Q3" (para os participantes do curso) e "QA3" (para os alunos participante das atividades do semestre anterior).

19 Entrevistas com alguns dos professores participantes do curso.

20 Levantamento e descrição de possíveis desdobramentos do curso por exemplo: formação de grupos, campanhas ou projetos nas escolas ou comunidades (horta, arborização, compras comunitárias e outros).

21 Avaliação da possibilidade de publicação dos resultados do trabalho, incluindo o material didático produzido, visando atingir professores em geral.

22 Promoção de um encontro com os professores para apresentar e discutir a situação da pesquisa.

23 Seminário com os pesquisadores observadores (S4) a fim de apresentar e discutir as observações relevantes, os resultados e as conclusões obtidos na pesquisa .

24 Redação final da dissertação.

\section{ANÁLISE DOS RESULTADOS}

- O primeiro grupo de resultados a ser avaliado diz respeito à preparação e à execução do curso-oficina de atualização e capacitação de professores. O foco de avaliação se dará sobre aspectos como: grau de interesse, procura e adesão ao curso; desenvolvimento das etapas e atividades propostas; natureza e quantidade de materiais didáticos produzidos; eficiência na transmissão/aplicação dos conhecimentos adquiridos no curso; problemas e dificuldades na execução do curso e outros.

O segundo conjunto de aspectos a ser analisado está associado às avaliações e conclusões sobre as hipóteses e questões teóricas inicialmente levantadas. Thiollent alerta que "o desenrolar e a avaliação de uma ação cultural são talvez mais difusos e menos evidentes do que no caso de atos técnicos bem definidos" (1985; 42). Concordamos com ele e apontamos a dificuldade de encontrar indicadores estritamente quantitativos para a avaliação das proposições iniciais. Conforme proposta desse autor optamos pelo uso de "apreciaçöes argumentativas", baseadas em parâmetros relativos e aproximativos para avaliação das hipóteses iniciais e dos resultados gerais do trabalho.

Os "instrumentos" para apreensão de tais parâmetros indicativos serão, principalmente:

a) avaliação da lista de interessados no curso;

b) consideraçōes e reflexões sobre as observaçöes, anotaçōes e registros (relatório das aulas, fotografias, gravaçöes e filmagens) feitas no transcorrer do curso;

c) relatório do diagnóstico inicial;

d) tabulação dos questionários aplicados aos professores e aos seus alunos;

e) análise das entrevistas com professores e seus alunos;

f) análise das avaliaçōes desenvolvidas pelos participantes do curso a cada aula ou atividade;

g) avaliações dos materiais e projetos didáticos desenvolvidos pelos educadores envolvidos;

h) registros do acompanhamento do cronograma;

i) avaliaçöes e considerações dos pesquisadores observadores;

Também serão importantes parâmetros avaliativos as eventuais produções e intervençōes promovidas pelos 
participantes do curso ou por seus alunos. Entre as diversas ações que poderão ser detectadas e usadas como indicadores supomos: produções para eventos como feiras de ciência ou concursos literários; mudanças de hábitos e comportamentos diante de aspectos relacionados ao assunto (por exemplo: opção por alimentos produzidos alternativamente); organização de grupos de reivindicação ou de estudos sobre o tema; instalação de hortas comunitárias nas escolas e intervenções direta na realidade local (por exemplo: campanhas junto a agricultores, consumidores de produtos agricolas, autoridades públicas, etc.).

Segundo Thiollent é necessário atentar para o desenrolar das ações propostas pois "da observa-ção e da avaliação dessas ações, e também pela evidenciação dos obstáculos encontrados no caminho, há um ganho de informação a ser captado e restituido como elemento de conhecimento" (1985: 22).

Por fim é preciso explicitar e considerar que a proposta metodológica da pesquisa, ao remeter à uma ação não totalmente pré-definida possibilita, no seu transcorrer, o surgimento de novas indagações, novos parâmetros e novos "instrumentos" de avaliação.

FIGURA 1 - ESQUEMA GERAL DA PROPOSTA INICIAL DE PESQUISA

\section{OBJETIVOS}

ESTIMULAR O QUESTIONAMENTO DO MODELO AGRICOLA CONVENCIONAL E A VALORIZAÇÃO DE PRODUTOS E INICIATIVAS AGRÍCOLAS ALTERNATIVAS, COMO PARTE DA BUSCA PELA SUSTENTABILIDADE SÓCIO-AMBIENTAL.

CONTRIBUIR PARA A MELHORIA DE PROCESSOS EDUCATIVOS ENVOLVENDO AS RELAÇÕES ENTRE AGRICULTURA E MEIO AMBIENTE.

\begin{tabular}{|c|} 
AMPLIAR OS CONHECIMENTOS SOBRE: \\
ABORDAGENS DAS RELAÇŌES AGRO-AMBIENTAIS NO \\
ENSINO FORMAL, A PARTIR DA EDUCAÇĀO AMBIENTAL.
\end{tabular}

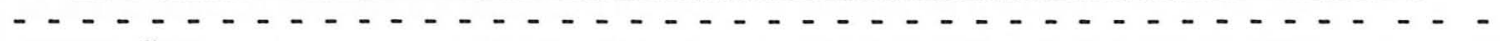

\section{QUESTÕES}

Q1 (QUESTÃO PRELIMINAR)

QUAIS OS ASPECTOSE TÓPICOS CENTRAIS DO TEMA?

Q2

Q3 (QUESTÃO NÜCLEO)

Q4

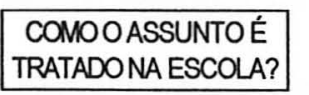

COMO AMPLIAR E MELHORAR A ABORDAGEM ESCOLAR DO TEMA?

QUAIS AS CONSEQ DESTA AMPLIAÇÃO?

ASPECTOSE
TÓPIOOS CENIRAIS
SCBREO ASSUNTO

\begin{tabular}{|c|c|}
\hline GRAUDE & INTERESSE DE \\
CONHECIMENTTO \\
EDUCADORESE \\
SOBRE O ASSUNTO
\end{tabular}

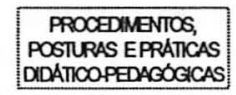

POTENCIAUDADES EDIFICULDADES

\section{PRESSUPOSTOS}

HÁ DESCONHECIMENTOE INEXPERIÊNCIA EDUCACIONAL SOBRE O TEMA
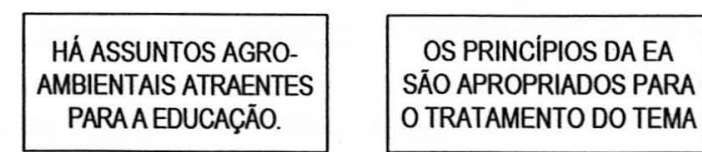

CURSOS DE APERFEIÇOAMENTO DE EDUCADORES PODEM CONTRIBUIR PIO ENSINO DO TEMA

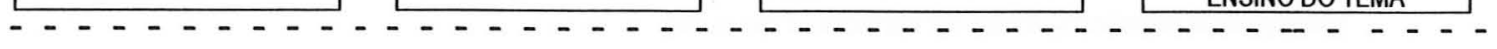

HIPÓTESES DE TRABALHO

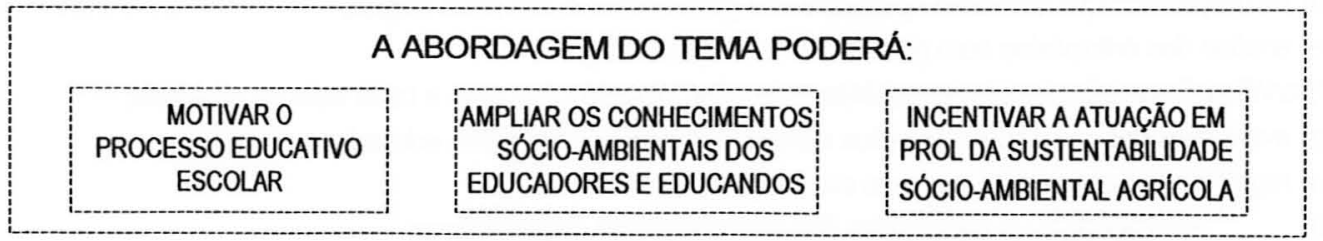




\section{"MEMORIAL DO CURSO-OFICINA DE APERFEIÇOAMENTO DE PROFESSORES: AS RELAÇÕES ENTRE AGRICULTURA E MEIO AMBIENTE”}

INICIATIVA VINCULADA AO PROJETO DE PESQUISA DE MESTRADO DENOMINADO: ABORDANDO AS RELAÇÕES ENTRE AGRICULTURA E MEIO AMBIENTE NO ENSINO FORMAL, ATRAVÉS DA EDUCAÇÃO AMBIENTAL - CONSIDERAÇÕES A PARTIR DE UM CASO 
130

APÊNDICE 1 - MEMORIAL do CuRso-oficina: "As RelaCōes Agricultura e MeIo Ambiente" FL.2

\section{ÍNDICE}

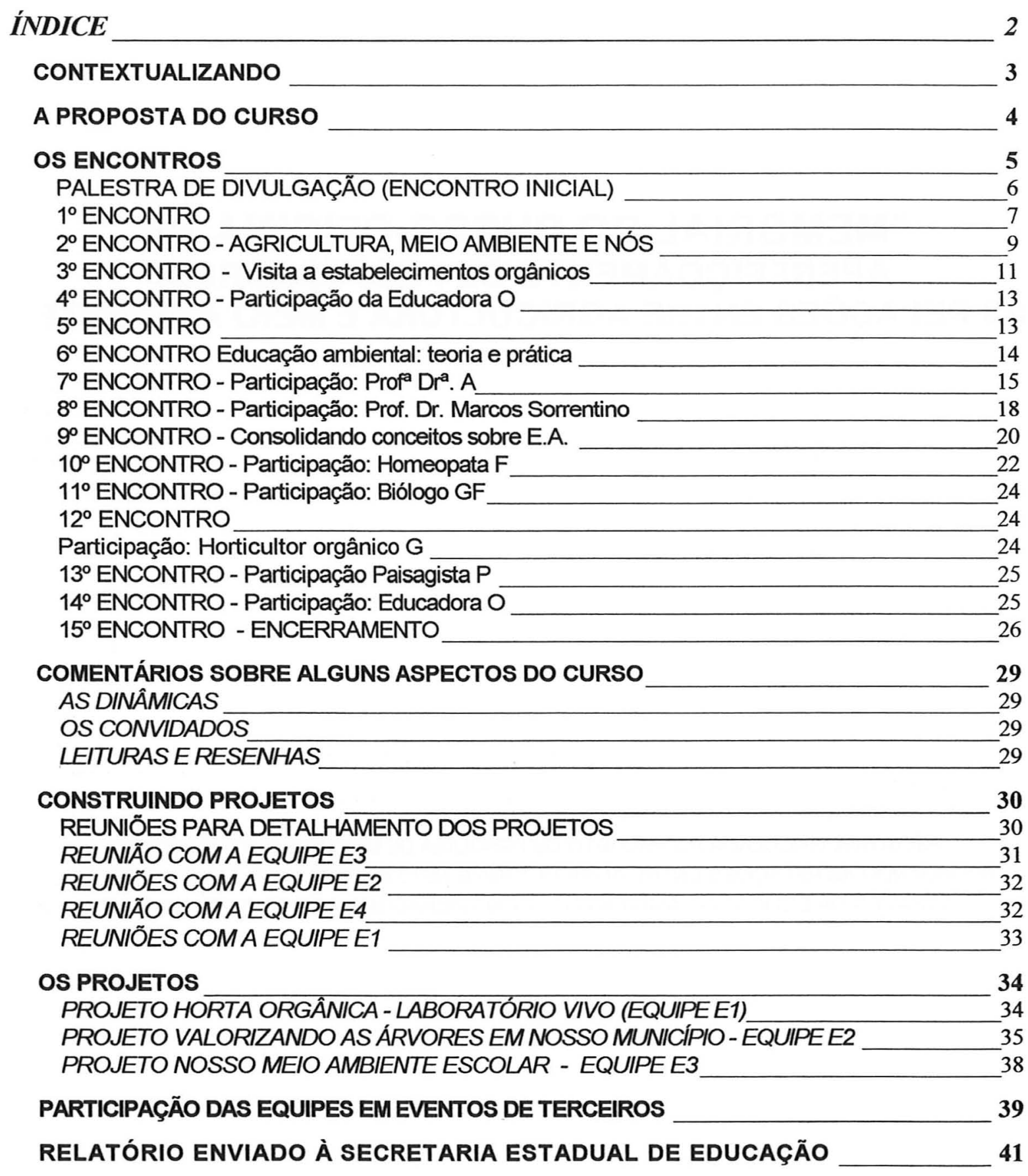




\section{Contextualizando}

Promoção e Coordenação Geral:

Prof. Antonio Vitor Rosa (Mestrando em Ciências Florestais pela ESALQ-USP)

Coordenação Institucional:

Benedita Aparecida de Barros (Assistente Técico-Pedagógica da Diretoria de Ensino de São Roque e região)

Orientação:

Prof. Dr. Marcos Sorrentino (Lab. de Educação e Política Ambiental - ESALQ-USP)

Locais de execução: São Roque e Ibiúna (SP) Período: mar/99 a nov/99.

Esclarecimentos

Esta iniciativa insere-se numa pesquisa promovida pelo mestrando Antonio Vitor Rosa sob orientação do Prof.Dr. Marcos Sorrentino como parte do Programa de Pós-Graduação do Departamento de Ciências Florestais da ESALQ-USP. O curso foi proposto e realizado como procedimento principal de levantamento de dados sobre a formulação, a implementação e a avaliação de propostas educacionais envolvendo as relações agricultura em meio ambiente.

Financiamento

\begin{tabular}{|l|l|}
\hline Despesas principais & Financiador principal \\
\hline Trabalho e diárias do coordenador geral & FAPESP-Fundação de Amparo à Pesquisa do Estado de São Paulo \\
\hline Materiais empregados nas atividades & FAPESP-Fundação de Amparo à Pesquisa do Estado de São Paulo \\
\hline Trabalhos da coordenadora institucional & Diretoria de Ensino de São Roque \& Região \\
\hline Instalações para as aulas & $\begin{array}{l}\text { Escolas da rede pública estadual, } \\
\text { principalmente a Escola Estadual Maria Angerami Scalamandré }\end{array}$ \\
\hline Diárias dos convidados & Pesquisador \\
\hline Transporte para atividades de campo & Auto Viação Cidade de lbiüna \\
\hline
\end{tabular}

É necessário destacar também que o curso e os projetos educacionais decorrentes dele tiveram um importante apoio institucional da Prefeitura Municipal de Ibiúna e em especial da Secretaria de Agricultura. 


\section{A PROPOSTA DO CURSO}

$\checkmark$ Tendo como temas centrais:

$\Rightarrow$ As relações entre agricultura e meio ambiente $\mathrm{e}$

$\Rightarrow$ A educação ambiental.

$\checkmark$ Os objetivos declarados do curso eram:

$\Rightarrow$ Apresentar os principais tópicos sobre os temas centrais;

$\Rightarrow$ Contribuir para aprimorar a capacitação dos cursistas para trabalhar numa perspectiva de educação ambiental;

$\Rightarrow$ Contribuir para diagnosticar a situação do ensino do tema;

$\Rightarrow$ Incentivar a pesquisa, a produção e a avaliação sobre ensino do tema.

$\checkmark$ A programação e os procedimentos buscavam:

$\Rightarrow$ Envolver os cursistas com os temas centrais,

$\Rightarrow$ Contribuindo para problematizar tanto as questões relativas à relação entre agricultura $\mathrm{e}$ meio ambiente como o ensino-aprendizagem deste tema,

$\Rightarrow$ Proporcionar uma reflexão crítica sobre os temas centrais, contribuindo para a construção de uma visão ambientalista por parte dos cursistas.

$\Rightarrow$ Estimular a ampliação do compromisso didático-pedagógico, social e político dos cursistas.

$\Rightarrow$ Ampliar os vínculos entre os participantes, em especial entre os cursistas de cada escola.

$\checkmark$ Entre os princípios orientadores do curso estavam:

$\Rightarrow$ Encarar a educação como um processo de mão dupla entre o educador que é também educando, e educandos que são também educadores. No caso específico é muito importante considerar que o educador-educando está em processo de formação (educando) e os educandos-educadores exercem funções de educadores.

$\Rightarrow$ Considerar os educandos enquanto sujeitos sociais, culturais e históricos que apresentam um importante acúmulo de conhecimentos e experiências e são dotados de uma complexa subjetividade.

$\Rightarrow$ Além de conhecimentos, procurar trabalhar: valores, comportamentos, atitudes e habilidades.

$\Rightarrow$ Levar em conta a razão, a emoção, a percepção e a intuição dos envolvidos no processo.

Conforme pode ser observado no quadro resumo do curso (Apêndice 3) após a palestra inicial aconteceram 15 encontros gerais. O curso-oficina foi estruturado em 4 módulos definidos em função dos temas e procedimentos centrais:

O Módulo 1 composto por 5 encontros, tinha como objetivos: apresentar informações, resgatar os conhecimentos e experiências dos participantes, possibilitar vivências relacionadas aos temas centrais, incentivar reflexões e sensibilizar os educandos para as relações entre agricultura e meio ambiente. Outro objetivo do módulo era fortalecer as relações interpessoais entre os cursistas.

No Módulo 2 o curso o focou as práticas e os princípios em educação ambiental, procurando associá-los ao ensino escolar. Foram 4 encontros durante os quais especialistas convidados apresentaram explanações e desenvolveram atividades em consonância com as principais correntes em educação ambiental. Também foram promovidas várias leituras e debates com a turma a fim de produzir um referencial coletivo de educação ambiental. Um momento 
APÊNDICE 1 - Memorial do Curso-oficina: "As Relacöes Agricultura e Melo Ambiente" FL. 5

importante foi a discussão sobre projetos educacionais e o início da formulação das propostas de projetos dos cursistas.

Durante o Módulo 3 foram promovidos: a) 5 encontros gerais nos quais foram desenvolvidas mini-oficinas visando fornecer mais subsídios para a construção dos projetos de cada equipe escolar; b) diversos encontros e reuniões por equipes para detalhar as propostas iniciais dos projetos das equipes c) reuniões e outros contatos com eventuais parceiros para os projetos.

No Módulo 4 a programação centrou-se basicamente no desenvolvimento e avaliação dos projetos. As atividades aconteceram de forma descentralizada e foi composto por: reuniões de encaminhamentos e de avaliações dos projetos; atividades educacionais junto aos estudantes (diversas fora da sala de aula); produção de painéis, exposições e relatórios para eventos; promoção e participação em eventos; preparação da apresentação final incluindo relatório de atividades e avaliação.

No decorrer dos trabalhos com a aprovação do curso pela Secretaria Estadual da Educação, houve uma adequação às normas deste órgão e o curso passou a ter oficialmente três módulos, sem no entanto implicar em outras alterações na estrutura e dinâmica proposta inicialmente. Na prática e também para efeito da pesquisa considerou-se a divisão em quatro módulos propostos inicialmente.

\section{OS ENCONTROS}

O uso da denominação "encontro" para cada aula do curso, foi uma opção do coordenador e visava valorizar o aspecto coletivo da atividade..

Todos os encontros tinham suas programações detalhadas previamente pelo coordenador, várias vezes discutidas em reuniões com o orientador Profo ${ }^{\circ} \mathrm{Dr}$. Marcos Sorrentino ou com os convidados, sempre considerando: os princípios da Educação Ambiental, os objetivos do curso e da pesquisa, os interesses dos cursistas, os recursos disponiveis, as possibilidades e especialidades dos palestrantes convidados e outros aspectos. Na programação procurávamos equilibrar e integrar: a) apresentações de informações e dados; b) momentos de expressão dos cursistas (apresentações de conhecimentos e relatos, manifestações pessoais, debates, ...); c) avaliações; d) articulação e consolidação de equipes. Os procedimentos incluíram: palestras, debates sobre leituras prévias; atividades de campo, vivências, dinâmicas de grupo, atividades não verbais (artísticas, corporais, etc.), sempre levando em conta o caráter demonstrativo de cada atividade para os cursistas.

Os encontros aconteciam geralmente aos sábados pela manhã, as três exceções foram: $04^{\circ}$ Encontro promovido num feriado e os $10^{\circ} \mathrm{e} 11^{\circ}$ encontros que ocorreram nas férias escolares.

A maioria das atividades foi desenvolvida em sala de aula, mas outros espaços também foram aproveitados: estabelecimentos rurais, reserva de mata atlântica, pátio da escola, proximidades da escola e Auditório Municipal.

Além dos encontros gerais aconteceram reuniões especificos (entre 2 a 4) com cada equipe de escola para a montagem dos respectivos projetos e várias outras durante o desenvolvimento destes, também ocorreram encontros para preparação e participação em eventos promovidos por terceiros.

A seguir é apresentado um relatório do curso e seus principais desdobramentos baseado principalmente nos registros do caderno de campo com apoio dos outros registros e mesmo através da memória deste pesquisador. 
134

APÊNDICE 1 - Memorial do CURSo-oficina: "As Relaçōes Agricultura e MeIo Ambiente" FL.6

\section{PALESTRA DE DIVULGAÇÃO (ENCONTRO INICIAL)}

O primeiro contato efetivo entre o coordenador e os cursistas foi através de uma palestra. aberta aos educadores ligados à Diretoria de Ensino de São Roque e região. A palestra tinha como objetivos declarados: discorrer sobre o tema central e divulgar a resposta do curso e sua relação com a pesquisa de mestrado do coordenador. Mas além disso a palestra foi usada como estratégia para atrair interessados no curso possibilitando-lhes um contato com o proponente da iniciativa antes das inscrições e para possibilitar a definição de critérios de seleção dos candidatos.

Foram enviados cartazes de divulgação (Apêndice 4) e avisos para todas escolas públicas de ensino médio de São Roque e Ibiúna. Como pode ser observado o material de divulgação contextualizava a palestra e o curso-oficina em relação ao projeto de pesquisa a que estavam associados. Para este evento se inscreveram mais de 60 pessoas. Uma alteração na data da palestra e problemas técnicos de comunicação na Oficina Pedagógica (falhas na rede telefônica ) provocaram uma grande ausência de inscritos, assim, no dia compareceram 22 pessoas.

A programação do dia foi composta por:

Apresentação de Antonio Vitor Rosa e de alguns participantes.

Palestra: "A Revolução Verde antecedentes e conseqüências.

Apresentação da proposta do curso e da pesquisa.

Discussões sobre o curso.

Encaminhamentos.

Considerando o número de presentes, foi aberta uma discussão sobre os critérios para seleção dos participantes e se verificou entre os presentes um fato muito interessante:

Inicialmente vários participantes apresentaram propostas que geralmente implicavam na sua escolha e no descarte de algum colega. Mas após alguns minutos de discussão as propostas foram convergindo no sentido da inclusão de todos os presentes no curso. Foi exatamente esta proposta que foi acatada.

Neste dia foram distribuídos alguns textos sobre problemas da agricultura moderna e solicitado que fossem lidos para o encontro seguinte.

Considerando que a maioria dos presentes eram oriundos de Ibiúna, cidade distante aproximadamente $20 \mathrm{Km}$ de São Roque, o grupo de uma das escolas propôs que as atividades fossem transferidas para aquela cidade. A proposta foi aceita pela grupo e pela representante da Oficina Pedagógica assim o curso foi desenvolvido na cidade de lbiúna.. 


\section{$1^{\circ}$ ENCONTRO}

\section{- Refletindo e expressando-se através da arte.}

Objetivos

a) estimular os cursistas a exporem suas preocupações educacionais relacionadas às questões ambientais, considerando suas funções de educadores;

b) permitir a troca de informações e experiências;

c) resgatar e valorizar os conhecimentos dos cursistas;.

d) aumentar o conhecimento interpessoal entre os participantes;

e) possibilitar aos cursistas a percepção de idiossincrasias e de convergências entre os membros da turma, a fim de: estimular a tolerância interpessoal, incentivar a aproximação entre os cursistas, contribuir para o fortalecimento de uma identidade coletiva e para a construção de futuras equipes de trabalho.

Materiais

Recursos para desenho e colagem: folhas de papel com uma face sem uso (cartazes velhos), estojos de giz de cera e de lápis coloridos, revistas velhas, tesouras e colas.

Procedimentos

- Após disponibilizar os materiais, o Coordenador passou a seguinte instrução: Através de técnicas artísticas (desenho e colagem) responder individualmente a questão:

"- O que me faz um professor preocupado com a questão ambiental?"

- Após 20 minutos foi organizada uma rápida exposição dos trabalhos produzidos.

- Na seqüência cada cursista apresentou seu trabalho explicando seu significado.

- Após as apresentações os cursistas foram estimulados a tecerem considerações sobre a atividade e seu tema, resultando em aproximadamente $30 \mathrm{~min}$. de explanações.

Produtos

a) Cartazes artísticos;

b) Fotos e transcrição das explicações sobre os cartazes;

c) Transcrição das explanações e discussões dos cursistas sobre: a educação, os professores, suas posições e preocupações educacionais e ambientais (Apêndice 6)

\section{Observaçōes e consideraçōes}

Esta atividade foi muito rica para caracterizar o conjunto dos participantes e implicou em desdobramentos no $2^{\circ}$ Encontro.

Conforme pode ser observado nas fotos e transcrições: as instruções e em especial a questão apresentada permitiram 2 tipos de abordagem: histórica e temática. Ambas foram ricas e contemplaram os objetivos iniciais. Seis participantes destacaram questões relacionadas à agricultura e outros 4 citaram alimentação e agricultura. A grande incidência de considerações sobre agricultura e sobre alimentos muito provavelmente foi um decorrência da palestra de divulgação realizada na semana anterior. Apenas 4 participantes fizeram referências à educação: um citou o fato de ser professor mas não atribuiu nenhuma particularidade a isto, apenas três explicitaram uma preocupação didáticopedagógica diante das questões ambientais (sendo duas delas divergentes).

Alguns aspectos observados nesta atividade merecem destaque:

a) A pequena incidência de reflexões na perspectiva educacional ou sobre a situação do educador durante as apresentações individuais.

b) As reflexões da prof ${ }^{a}$ Safira destacando-se pela sua profundidade e adequação ao enfoque educacional. 
c) A grande diversidade de representações sobre meio ambiente.

d) Apesar das respostas inicias dos participantes pouco atentarem para questões educacionais, as manifestações durante o debate centraram-se nestas questões fazendo emergir dois grupos de posições que podem ser assim sintetizadas:

Posição A: "nada é em vão, sempre fica alguma coisa" e

Posição B: "Como mudar a situação de nota Dez na escola e Zero na vida ?"

\section{Apresentação do filme "Agressão ao Homem"}

Objetivos

a) apresentar informações sobre problemas da agricultura moderna;

b) provocar um impacto emocional (desconforto) nos cursistas;

Materiais

- Filme: Agressão ao Homem, produzido pela BBC-Londres, s.d., baseado no livro: Colbom, T.; Dumanoski, D. e Peterson J. OFuturo Roubado. Porto Alegre: LP\&M, 1997.

- Resenha impressa do filme.

Procedimentos anotações.

- Distribuição de uma resenha do filme, visando reduzir a dispersão ou a perda de informações durante eventuais

- Apresentação de alguns trechos selecionados do filme (aproxim. 16 min.).

Observações e consideraç̃es

Devido a uma troca inadvertida, a fita levada para a apresentação não foi aquela previamente preparada, obrigando a edição durante a apresentação o que provocou a dispersão e um certo desconforto dos cursistas.

\section{Diagnosticando em grupo a situação geral da agricultura}

\section{Objetivos}

a) desenvolver diagnósticos sobre a agricultura atual;

b) possibilitar aos cursistas um momento de explicitação dos aspectos considerados mais importantes ou que geram maior preocupação envolvendo a agricultura e o meio ambiente.

c) forçar a produção de textos sintéticos;

d) exercitar o trabalho, o debate e a negociação em grupo;

e) possibilitar trocas e aproximações interpessoais.

Materiais

Cartolinas e pincéis-atômico.

Procedimento

- Sorteio de 4 grupos formado por 4 ou 5 cursistas preferencialmente oriundos de diferentes escolas.

- Instrução: "Partindo das experiências pessoais, das leituras dos textos distribuídos no encontro anterior e no vídeo apresentado, identificar a situação da agricultura numa perspectiva genérica sem se preocupar com regiões ou produtos especificos."

- Após alguns minutos solicitou-se que cada grupo registrasse a síntese das discussões numa cartolina.

- Após 25 minutos do início dos debates, cada grupo apresentou sua cartolina, explicando e justificando suas conclusões. Por fim alguns cursistas teceram consideraçōes sobre as apresentaçöes 
APÊNDICE 1 - Memorial do CURSO-Oficina: "As Relacōes Agricultura e MeIo Ambiente" Fl.9

- Conjunto de frases e pequenos textos sintetizando os diagnósticos sobre agricultura (Apêndice 7).

\section{Observações e consideraçōes}

A palestra da semana anterior e o video apresentado momentos antes direcionaram as atenções para os aspectos negativos, provocando em vários cursistas um sentimento de angústia, muito bem explicitado por um dos grupos.

Utilizando o conjunto de textos acima citado o coordenador compôs o texto coletivo: "Nosso Diagnóstico Geral sobre a Agricultura Moderna" (Apêndice 8) distribuido posteriormente. Segundo avaliação do coordenador, a produção de textos coletivos é uma boa forma de resgatar as discussões, valorizar os conhecimentos e opiniões do grupo e dar maior concretude aos trabalhos. Mas a falta de tempo na programação impediu o debate sobre o diagnóstico e mesmo sobre este tipo de procedimento e produto.

\section{Atividades complementares}

- Distribuição do resumo do Projeto de Pesquisa e da programação do módulo 1.

- Levantamento de instituições a serem pesquisadas quanto a situação da agricultura em Ibiúna. Formação de grupos de 2 ou 3 pessoas para visitar estas instituições durante a semana.

- Aos professores que não se encaixaram em nenhum grupo foi solicitado que organizassem uma proposta de questionário para os alunos, cópias do questionário apresentado na palestra foram distribuídas como uma referência ao novo questionário.

\section{Avaliação rápida do dia}

Objetivos

a) Captar o sentimento dos cursistas quanto ao conjunto de atividades do dia;

b) Valorizar e exercer efeito demonstrativo quanto a atividades de avaliação.

Procedimentos

O coordenador solicitou a quem desejasse que falasse uma palavra ou frase sintetizando seu sentimento quanto ao encontro.

Resultados

Metade da turma se expressou. As manifestações foram::

" - Esperança".

"- Esperança no projeto".

"- Além da expectativa".

"- Renovação".

" - Preocupação com os problemas ambientais".

"- Aumentando a preocupação com as gerações futuras".

"- Compromisso com o nosso espaço na escola".

"- Compromisso com responsabilidade".

\section{$2^{\circ}$ ENCONTRO - AGRICULTURA, MEIO AMBIENTE E NÓS}

\section{Avaliando as atividades do encontro anterior .}

$\underline{\text { Objetivos }}$ 
a) proporcionar aos cursistas um momento de verbalização das vivências do encontro anterior (auto-avaliação);

b) possibilitar o intercâmbio e o aprofundamento das experiências e das reflexões provocadas pelas atividades anteriores;

c) permitir novos relatos sobre experiências concretas e pessoais envolvendo a modernização agricola;

d) constituir um indicador sobre o andamento do curso;

Procedimentos

Palavra aberta a todos, sem tempo determinado.

Produtos Relatório redigido durante o transcorrer do encontro por um cursista.

Observações e consideraç̃os

Esta atividade tomou um tempo muito maior que o esperado. O Coordenador permitiu e até incentivou as colocações considerando a riqueza das intervenções e reflexões que emergiram, incluindo depoimentos emocionados e ricos em detalhes históricos plenamente apropriados à temática em questão e os objetivos do curso.

Um dos aspectos apontado como positivo por vários participantes foi quanto às atividades trabalharem o emocional, além do racional. Foi explicitado a grande diversidade de histórias de vida de cada participantes. A percepção disto levou os participantes a constatarem que: apesar de, em geral, serem colegas de convivio diário, só se conhecem em relação aos aspectos profissionais. A explicitação da multiplicidade de histórias de vida remeteu um dos cursistas a se pronunciar sobre a questão dos professores, geralmente, analisarem os fenômenos e situações a partir de suas experiências e perspectivas, desconsiderando que os alunos têm perspectivas diferentes.

\section{Aula expositiva: Agricultura, meio ambiente e sociedade.}

Objetivos Apresentar informações sobre:

a) as relações e os impactos ambientais da agricultura, incluindo processos erosivos e número de aplicações de agroquímicos em certos alimentos;

b) a expansão agricola e a distribuição espacial da degradação agro-ambiental no Brasil.

c) distribuição de terras no país, segundo os grupos sociais.

Materiais: Transparências.

Observacões e consideraçōes

A intenção não foi esgotar o assunto e sim levantar alguns aspectos. Visando possibilitar a consolidação e o aprofundamento de informações sobre o assunto foram distribuidos aos participantes: diversos textos de livros e revistas especializadas, além disso em encontro posterior foi distribuído o livro paradidático de autoria do Coordenador do curso obtido gratuitamente junto à editora (Rosa, A. V. Agricultura e Meio Ambiente. São Parreira: Atual Editora, 1998).

\section{Relato dos cursistas sobre suas pesquisas na semana.}

\section{$\underline{\text { Objetivos }}$}

A solicitação de pesquisas sobre a agricultura na cidade visou:

a) aumentar o envolvimento dos cursistas com a temática;

b) centrar o enfoque na escala local e no nível do cotidiano dos envolvidos;

c) valorizar o instrumento da pesquisa no ensino;

d) valorizar a informação e o conhecimento produzido pelos cursistas.

\section{Procedimentos}

Cada grupo apresentou um relatório oral sobre suas entrevistas e observações desenvolvidas com pessoas e instituições listadas no encontro anterior. Ao final da atividade o coordenador solicitou que cada grupo transcrevesse sua pesquisa como forma de registro e valorização do trabalho.

Produtos 


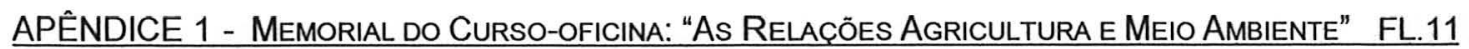

Vários relatórios foram gerados e entregues posteriormente: Entrevista com diretores do Sindicato Rural, entrevista com técnicos da Casa da Agricultura e outros .

Observações e considerações

Vários participantes demonstraram satisfação com a atividade e com o tipo de recepção que técnicos e autoridades conferiram ao trabalho. Considerou-se que tal recepção decorre de um reconhecimento do valor da "função professor".

Diversas manifestações indicaram que o propósito da atividade de aumentar o envolvimento dos professores com o projeto foi obtido.

\section{Atividades complementares}

Distribuição de textos para leitura e resenha (em casa) sobre agricultura alternativa e sobre as relações entre produção de alimentos e fome.

Solicitação para confeç̧ão do relatório das pesquisas.

Distribuição de um pequeno projeto educacional e solicitação para leitura, avaliação e reflexão sobre projetos educacionais, eventualmente a formação de grupos de discussão sobre futuros projetos.

\section{$3^{\circ}$ ENCONTRO - Visita a estabelecimentos orgânicos}

\section{Preparação para a visita de campo}

\section{Objetivos}

a) Elencar as expectativas dos cursistas quanto ao que seria observado na visita;

b) Discutir procedimentos e instrumentos de registro da atividade;

c) Informar a programação e organizar os participantes entre os veiculos disponiveis;

d) Destacar a importância do planejamento prévio dos objetivos, das ações e dos instrumentos de registro em atividades extraclasse.

Procedimentos

Os cursistas citavam os aspectos que esperavam encontrar ou observar na visita e o coordenador registrou no quadro negro. Na seqüência o coordenador questionou sobre os procedimentos e instrumentos que seriam empregados, novamente conforme eram propostos, eram registrados no quadro negro.

Produtos

Um texto, contendo algumas considerações sobre procedimentos para a vista e a lista de expectativas apresentadas no dia, foi produzido e distribuído posteriormente pelo coordenador do curso.

\section{Observações e considerações}

O planejamento das observações e dos procedimentos foi apenas indicativo e genérico, sem detalhamentos ou definição de responsáveis. As vantagens e desvantagens dessa opção não foram analisadas em maior profundidade, mas notamos que o encaminhamento deixou os cursistas mais a vontade e imprimiu um caráter de visita "quase familiar" à atividade, possibilitando a turma o envolvimento com o "objeto-processo" observado e a cada um a atenção nos aspectos considerados mais atraentes. No entanto é possivel supor que um modelo clássico de pesquisa de campo incluindo: roteiro de observações, organização de equipes de trabalho, distribuição de tarefas entre os participantes, registros mais detalhados, etc. poderia gerar relatórios melhor sistematizados com dados mais detalhados.

\section{Visita a horticultores-orgânico}

\section{$\underline{\text { Objetivos }}$}


- Observar e ter contato com a produção agricola alternativa desenvolvida na região incluindo aspectos como: os produtos, as pessoas envolvidas, as técnicas empregadas, os aspectos econômicos, o destino da produção, a organização e a infra estrutura.

- manter contato com produtores orgânicos.

$\underline{\text { Recursos }}$

Veiculos dos participantes para locomoção até as propriedades. A alteração da data da visita inviabilizou a solicitação de transporte junto a prefeitura local, além disso as chuvas constantes provocavam dificuldades de acesso através de veículos coletivos.

Procedimentos

Inicialmente foi visitado o produtor $\mathrm{G}$. Após caminhar até o centro da estabelecimento a turma ouviu do produtor uma agradável, clara, concisa e consistente explanação sobre agricultura sustentável e sobre a proposta de trabalho e de vida adotada por ele e sua familia. Em seguida o produtor mostrou as instalações da propriedade, explicando os propósitos e os conceitos envolvidos. As principais instalações observadas foram: horta, estufa-sementeira, galpão de embalagens, quadro de planejamento, cabril, aviário e composteira.

A programação inicial previa duas visitas com durações entre uma e duas horas, porém o tempo empregado para cada visita foi bem maior. Assim a primeira visita foi encerrada aproximadamente as 12 horas, considerando a programação apresentada em encontros anteriores a turma foi informada que para efeito da carga horária os cursistas estavam dispensados, contudo apenas uma pessoa não pode fazer a visita da tarde em função de compromisso previamente assumido.

Terminada a visita a turma se dirigiu à cidade para o almoço que reuniu quase todos os cursistas. Durante este almoço, além da descontração e de conversas sobre amenidades ocorreram diversas discussões e considerações sobre a visita.

O segundo estabelecimento visitado foi o do Sr. João Dias. Atendendo a um convite anterior, a visita foi acompanhada pela engenheira agrônoma Marilia que trabalhava com agricultura orgânica na região. Os cursistas efetuaram uma caminhada pelo estabelecimento guiados pelo produtor e pela engenheira os quais foram mostrando e tecendo considerações sobre os cultivos, as técnicas, o solo, a produção, etc.

Conforme previsto as visitas foram fotografadas e filmadas; parte das explicações e declarações foram gravadas e todos os cursistas anotaram observações e relatos.

\section{Produtos}

Relatórios das visitas; transcrição da mini-palestra do produtor G; transcrição da avaliação rápida feita no dia (Apêndice 11); coleção de fotos e fita de vídeo.

\section{Observaçōes e consideraçōes}

Segundo avaliação do coordenador e de alguns cursistas as atividades deste dia incluindo a mini-palestra do horticultor $\mathrm{G}$ (aproximadamente $30 \mathrm{~min}$.), as explanações dos produtores e da engenheira agrônoma, as apresentações das instalaçōes das propriedades, as conversas com os produtores e familiares e a compra de produtos orgânicos constituiu-se um dos encontros mais importante e marcante do curso.

Um dos pontos positivos deste encontro foi o fato da programação e das circunstâncias possibilitarem uma determinada seqüência, a saber:

i) inicialmente os cursistas tiveram contato com um produtor que apresenta um consistente posicionamento ideológico quanto a agricultura alternativa;

ii) a seguir, durante o almoço, os cursistas puderam trocar impressōes e esboçar avaliaçöes sobre o observado;

iii) no periodo da tarde o contato foi com outro produtor orgânico que apresenta um perfil mais pragmático e imediatista, diferente do primeiro;

iv) no percurso de retorno novamente os cursistas puderam tecer considerações, avaliações e comparações sobre as visitas.

Observar que a diferença de perfil entre os produtores foi considerada no planejamento das visitas e permitiu aos cursistas desenvolverem comparaçöes entre os produtores. Grosso modo houve uma tendência de avaliar a postura e os 
APÊNDICE 1 - Memorial do Curso-oficina: "As Relaçöes Agricultura e MeIo Ambiente" FL.13

procedimentos do sr. G como "utópicas", "filosóficas", "teóricas", pouco vinculadas à dinâmica capitalista atual, enquanto que as posições do produtor João Dias foram tidas como o mais apropriada. Ao final do dia os cursistas puderam compor uma perspectiva mais ampla quanto a proposta orgânica.

O deslocamento em veículos dos cursistas, as condições da estrada e o longo tempo gasto no deslocamento até as propriedades além possibilitar os debates e trocas de impressões proporcionaram momentos de descontração, conversas e aproximação entre os participantes.

Outro destaque do dia foi a disposição dos cursistas tanto para enfrentar chuva e barro como para desenvolver atividades no período da tarde sem programação prévia.

A observação deste encontro levou-nos à algumas reflexões: "A vivência dá concretude a temática, configurando um novo tipo de relação entre os educandos e o assunto abordado". "Ouvir testemunho de vida parece ser algo muito significativo no processo educativo".

Outro fato interessante foi a descoberta que uma das professoras cursistas fez quanto ao fato de um de seus alunos ser filho do sr. João Dias, isto nos trouxe outra reflexão: "A imersão na realidade extramuros leva a escola a se (re)encontrar.

\section{$4^{\circ}$ ENCONTRO - Participação da Educadora O Serrano}

\section{Palestra: Percebendo o mundo a partir de uma perspectiva holística}

Objetivos

a) apresentar uma sintese da visão de mundo a partir de uma perspectiva holística;

b) relacionar essa visão de mundo com a educação e com agricultura sustentável.

Materiais

O principal recurso utilizado foi a lousa. Ao fim da atividade a palestrante forneceu várias folhas com esquemas que sintetizando o tema tratado, as quais foram reproduzidas e distribuídas aos cursistas em encontro posterior.

Procedimentos

A palestra se desenvolveu num ritmo agradável e cativante, com muita clareza e ótimo uso das lousas. Os cursistas puderam apresentar suas questões durante a palestra, as quais eram respondidas na medida do possivel.

Produtos: Fitas de vídeo e transcrição de trechos da palestra.

\section{Observaçōes e consideraçōes}

O tema foi uma grande novidade, despertando interesse e provocando impacto pessoal em muitos cursistas. $O$ planejamento inicial do curso previa para esta aula, uma abordagem mais específica sobre agricultura alternativa / sustentável. Em reunião prévia a palestrante apresentou sua preocupação em contextualizar as propostas de agric. alternativa a partir de uma nova compreensão da realidade e em especial da vida. No entanto o tempo foi insuficiente para toda a empreitada. Conforme a própria palestrante, o assunto mereceria muitas horas de apresentação. Comparando-se com o tempo total da palestra, as considerações sobre as implicações da perspectiva holística para a agricultura foram muito rápidas, dificultando a apreensão da maioria dos cursistas.

A figura cativante da palestrante, o tema novo e provocante, o pouco tempo para tratar as diversas questões surgidas, contribuiram para uma sensação de "quero mais" entre os cursistas.

\section{$5^{\circ}$ ENCONTRO}

\section{Considerações sobre agricultura alternativa}

\section{Objetivos}

a) Apresentar alguns aspectos sobre agricultura orgânica ainda não tratados no curso; 
b) Reforçar certos aspectos já tratados nas palestras anteriores ou nas leituras.

Observações e consideraçōes

Esse foi um dos piores encontros do curso. Ocorre que as visitas aos produtores (atividade ao ar livre e num ambiente rico em novidades) e a palestra da educadora $\mathrm{O}$ (detentora de uma alta capacidade de comunicação e sedução), imprimiram uma certa expectativa na turma. No entanto o coordenador se propôs a desenvolver uma aula expositiva com todos os incômodos quando comparado a uma visita e sem a capacidade de sedução da educadora. Os cursistas estavam mais agitados que em outros encontros, as conversas paralelas à explanação do coordenador foram uma constante, o coordenador não teve a iniciativa de abrir mão da apresentação de determinados "conteúdos" e propor uma atividade que aproveitasse o estado dos cursistas.

\section{$6^{\circ}$ ENCONTRO Educação ambiental: teoria e prática}

\section{Expressando-se sobre o curso: andamento e expectativas}

Objetivos

a) Avaliar o andamento do curso, levantando pontos positivos e negativos;

b) Levantar as expectativas dos cursistas;

c) Forçar a expressão de todos os cursistas;

Materiais

Uma folha de papel $(30 \mathrm{~cm} \times 30 \mathrm{~cm})$

Procedimentos

$\mathrm{O}$ coordenador iniciou a atividade fazendo uma dobradura com o papel e dizendo que: "O curso poderia ser pensado como uma viagem, na qual todos são passageiros e também tripulantes" e que naquele momento cada um deveria expressar o "que estava achando da viagem, apontando os pontos positivos e negativos". O coordenador continuou, solicitando que cada um apresentasse suas expectativas para aquela viagem. Passou então o barquinho de papel que acabara de montar para o cursista ao seu lado. Cada cursista fazia sua explanação e passava o barquinho p/ o companheiro(a) ao lado.

Produtos:

Transcrição das explanações dos cursistas (apêndice12).

\section{Observaçōes e consideracōes}

O recurso do barquinho mostrou-se válido para o propósito de fazer com que todos se expressassem, isto foi pensado devido a percepção, em eventos anteriores, quanto a existência de um grupo de 5 ou 6 cursistas que por serem mais extrovertidos tinham a predominância de fala e talvez de posiçöes. O barquinho funcionou como uma "tribuna livre e garantida" para a qual todos estavam atentos e respeitando o momento de expressão do colega.

\section{Discutindo o entendimento sobre Educação Ambiental.}

$\underline{\text { Objetivos }}$

a) Promover a reflexão e o debate sobre educação ambiental.

b) Estimular a seleção dos principais aspectos da educação ambiental. 
APÊNDICE 1 - Memorial do Curso-oficina: "As Relaçöes Agricultura e Meio Ambiente" Fl.15

c) Contribuir para a consolidação do entendimento sobre E.A.

$\underline{\text { Recursos e Materiais }}$

- Textos sobre educação ambiental fornecidos previamente

- Fichas de papel cartolina $(30 \mathrm{~cm} \times 20 \mathrm{~cm})$ e pincéis-atômico;

Procedimentos

Considerando que no encontro anterior cada participante recebera 2 cópias distintas de um total de 4 textos diferentes distribuídos à turma, os cursistas foram divididos em grupos de 5 pessoas, procurando-se reunir leitores de textos diferentes em cada grupo.

Foi então solicitado aos participantes que a partir de suas leituras, suas formações e suas experiências, discutissem: "-Quais os 3 principais aspectos da Educação Ambiental ?"E após alguns minutos sintetizassem em diferentes fichas cada um dos aspectos escolhidos. Na seqüência as fichas foram organizadas pelo coordenador e participantes em famílias de assuntos e fixadas no quadro.

Iniciou-se então um debate com todos os cursistas. No decorrer das discussões algumas fichas foram completadas ou modificadas e outras foram incluidas.

Produtos a) Transcrição das fichas

b) texto coletivo articulando todas fichas preparado pelo coordenador (Apêndice 13).

\section{Observacōos e considerações}

O procedimento de geração de um texto coletivo foi pouco aproveitado neste curso, os textos sempre foram produzidos pelo coordenador e não houve nenhum tipo de comentário sobre o conteúdo. Por outro lado os participantes expressaram satisfação em perceber que suas idéias poderiam ser articuladas e apresentadas como um produto. Os cursistas chegaram a receber solicitação deste texto por parte de policiais florestais.

\section{Deliberações sobre encaminhamento do curso}

Objetivos a) definir critérios para convite de outros professores para o encontro seguinte;

b) exercitar a tomada de decisões coletivas;

c) aumentar o senso de apropriação e responsabilidade dos cursistas diante da proposta.

Procedimentos Discussão geral a partir de algumas considerações do coordenador.

\section{Atividades complementares:}

Informes sobre a Exposição Agro-Industrial de Ibiúna programada pela Prefeitura para setembro. Uma cursista expressou seu interesse em incluir no evento "atividades" e "elementos" relacionados à agricultura orgânica. Uma reunião foi agenda para tratar do assunto.

Os cursistas professores da Escola Roque Bastos solicitaram ao coordenador sugestões para a Mostra Ecológica organizada por esta escola (relatório e comentários da reunião específica no caderno de campo).

Solicitação aos cursistas para entregarem os relatórios e resenhas dos encontros anteriores.

Organização da lista de telefones dos participantes, a qual foi reproduzida e distribuída no encontro seguinte.

\section{Considerações gerais sobre o encontro}

Este foi um dos melhores encontros do curso tanto pelo barquinho quanto pela discussão sobre EA.

\section{$7^{\circ}$ ENCONTRO - Participação: Profa Dra. "A"}

\section{preparativos :}

Com o objetivo de detalhar a programação do encontro, o Coordenador e a profa "A" se reuniram 5 dias antes. Após ouvir um pequeno relato do perfil e das demandas do grupo, a professora apresentou sugestões de atividades, na 
seqüência o coordenador ponderou algumas considerações e propôs algumas alterações. Desta forma foi definido a programação genérica do encontro.

\section{Apresentação dos participantes}

Objetivos

a) permitir a apresentação dos cursistas para a professora e para outros convidados e vice-versa;

b) aprofundar os conhecimentos interpessoais da turma;

c) valorizar o componente afetivo no contexto educacional;

Procedimentos

Cada participante deveria; "- Dizer o nome e o que mais gosta".

\section{Observaç̃es e considerações}

Numa avaliação posterior alguns participantes sugeriram que a apresentação deveria incluir também: “- $O$ que menos gosta".

\section{Aquecimento corporal}

Objetivos

a) relaxar o grupo;

b) aumentar o entrosamento do grupo;

c) valorizar atividades corporais no ensino.

Recurso

Espaço amplo e desocupado na sala de aula

Procedimentos

Execução de vários exercícios como: caminhar, trocar olhares, cumprimentar com as costas, abraçar e outros.

\section{Bolando usos alternativos para ...}

$\underline{\text { Objetivos }}$

a) exercitar a criatividade;

b) ressaltar ampla possibilidade de percepção e uso dos objetos.

Materiais

Uma tampa de caneta esferográfica comum.

\section{Procedimentos}

A professora colocou no centro da roda formada pelos participantes uma tampinha de caneta e solicitou que cada um anotasse os possiveis usos não convencionais para aquele objeto. Após alguns minutos os participantes apresentaram suas propostas, as quais foram anotadas na lousa constituindo uma lista com mais de 20 usos diferentes.

\section{Observando o entorno da escola}

$\underline{\text { Objetivos }}$

a) exercitar o olhar;

b) estimular o ensino a partir do cotidiano (local) dos educandos;

\section{Procedimentos}


APÊNDICE 1 - MEMorial do CuRso-oficina: "As RelaçöEs Agricultura e MeIo Ambiente" FL.17

Inicialmente a professora informou que seria feita uma caminhada por uma determinada avenida, solicitou então que os participantes anotassem em uma folha o que esperavam ver no percurso. Os participante sairam então para a atividade de campo, munidos de caneta e caderno de anotações. Observar que a folha com expectativas ficou na sala. O percurso total durou cerca de 1 hora.

Observacõos e consideracõos

Ver os desdobramentos dessa atividade na atividade seguinte.

\section{Retratando e avaliando o observado}

$\underline{\text { Objetivos }}$

a) possibilitar a discussão e a reflexão sobre uma realidade concreta dos educandos;

b) destacar a ocorrência de diferentes de olhares sobre a mesma realidade;

c) demonstrar a possibilidade de produção de conhecimentos locais;

d) levantar a possibilidade de execução de diagnósticos ambientais em pouco tempo;

Materiais

Cartolina, lápis de cor e giz de cera.

Procedimentos

Foi solicitado aos participantes que reunidos em grupos de 4 ou 5 pessoas discutissem e retratassem nas cartolinas o que haviam observado na atividade anterior.

Após 20 min. cada grupo apresentou e explicou sua cartolina

Produtos: cartazes e fita cassete.

Observações e considerações

Esta foi uma das atividades que mais marcou a maioria dos cursistas.

\section{Tópicos sobre Educação Ambiental}

Objetivos

Discorrer sobre tópicos de educação ambiental.

Procedimentos

Palestra e respostas às questões apresentadas.

\section{Observações e considerações}

O tempo foi insuficiente para aprofundamentos. Devido a expectativa diante do perfil da palestrante, apresentada pelo coordenador nos encontros anteriores, alguns cursistas declararam certa frustração pela pequena abordagem do tema PCNs.

\section{Considerações gerais sobre o encontro}

Nas avaliações deste encontro ficou evidente as diferenças entre os participantes quanto a: formação, experiência, expectativa e perspectiva sobre ensino. A grande maioria considerou muito bom o encontro, no entanto alguns esperavam um maior aprofundamento teórico sobre os PCNs.

Observar que a programação apoiada em atividades práticas foi uma opção do coordenador considerando as demandas que o grupo vinha apresentando nos encontros anteriores.

Produto: Planilhas de avaliação do dia preparadas durante o $9^{\circ}$ encontro. 


\section{$8^{\circ}$ ENCONTRO - Participação: Prof. Dr. Marcos Sorrentino}

\section{Reunião de planejamento do encontro}

Esta reunião, executada 4 dias antes do encontro, visou preparar as atividades do dia considerando:

a) os objetivos gerais do curso e da pesquisa;

b) a tarefa específica de configuração dos projetos dos cursistas por escolas;

Procedimentos

Revisão do andamento do curso até aquele momento.

Discussão sobre possiveis atividades e procedimentos.

Projeções sobre encaminhamentos.

\section{Apresentação - nome e características pessoais}

\section{$\underline{\text { Objetivos }}$}

a) possibilitar ao convidado conhecer o nome dos participantes;

b) aprofundar os conhecimentos interpessoais;

c) possibilitar aos participantes a reflexão e a expressão de suas características pessoais;

d) criar um ambiente de descontração.

Materiais

Caneta e papel

Procedimentos

- Cada participante escreveu o nome ou apelido na folha.

- Para cada letra o participante deveria apresentar uma característica pessoal. Esta letra poderia ser usada no início da palavra que identificava a característica ou em outra posição.

- Após alguns minutos cada participante dizia seu nome e as características pessoais.

\section{Observações e consideraçōes}

Esta atividade foi apreciada pela grande maioria da turma. Foi reproduzida pela Equipe E2 em um encontro promovido com seus alunos.

\section{Considerações sobre Educação Ambiental}

\section{Objetivos}

Apresentar algumas consideraçães sobre educação ambiental, destacando questões como:
a) participação;
b) modalidades de aproximação com as questões ambientais;
c) transformação social;
d) prioridades;
e) procedimentos e técnicas.

Procedimento

Exposição oral, diálogo com os participantes e respostas a perguntas.

\section{Produtos}

A exposição foi transcrita e adaptada pelo Coordenador, gerando um texto que foi distribuido para todos os participantes posteriormente. 
APÊNDICE 1 - Memorial do Curso-oficina: “As Relacoōes Agricultura e MeIo Ambiente” Fl.19

\section{Observações e considerações}

A apresentação foi muito densa em conteúdos e conceitos imprimindo certa dificuldade de acompanhamento para vários participantes, contudo graças a transcrição foi possivel uma releitura da apresentação.

\section{Entrosamento da turma}

Objetivos

a) melhorar o entrosamento entre os participantes;

b) promover um momento de descontração e movimentação corporal;

c) valorizar o trabalho coletivo;

$\underline{\text { Recursos }}$

Espaço livre na sala

Procedimentos

- Formação de uma roda com os participantes bem juntos (encostando ombro com ombro dos vizinhos) e os braços estendidos para a frente formando um "amontoado de mãos".

- um participante deve colocar sua mão esquerda para trás e com a sua mão direita segurar uma mão esquerda qualquer, em seguida a pessoa que teve a sua mão esquerda segura deve com a mão direita segurar uma mão esquerda e assim sucessivamente.

- quando estiver sobrando apenas uma mão direita ela deve segurar a mão esquerda do primeiro participante que até este momento estava aguardando com sua mão esquerda. Em seguida procura-se abrir a roda.

\section{Refletindo sobre a escola e nós}

\section{Objetivos}

a) Estimular a reflexão sobre o papel da escola;

b) Estimular a explicitação dos sonhos pessoais quanto ao ensino e quanto à agricultura sustentável.

Materiais:

- Fichas de cartolina ( $25 \mathrm{~cm} \times 16,5 \mathrm{~cm})$, pincel atômico e painel de exposição.

Procedimentos

- Solicitação para os cursistas fecharem os olhos e refletirem sobre o papel da escola e sobre os seus sonhos pessoais quanto a construção da agricultura sustentável.

- Após alguns minutos formou-se duplas e cada participante relatou ao colega suas reflexões. Em seguida as duplas se juntaram, formando grupos de 4 ou 5 pessoas, e continuaram a discussão. A sintese das discussões e dos sonhos de cada grupo foi anotada nas fichas de cartolina e fixada no painel de exposição.

\section{Refletindo e discutindo sobre os obstáculos}

\section{Objetivos}

a) estimular a reflexão dos participantes quanto aos problemas, dificuldades e carências para a realização de projetos envolvendo a escola.

b) fornecer subsídios para o futuro planejamento de produtos educacionais.

Materiais: $\quad$ mesmo da atividade anterior.

\section{Procedimentos}

- Discussão em grupo,

- Anotação da síntese das discussões em fichas que posteriormente fixadas no painel. 
- Após a visualização cada grupo explicou sua ficha.

Produtos: $\quad$ Transcrição das fichas sobre obstáculos (Apêndice 17).

\section{Relatando projetos conhecidos}

Objetivos

Elencar projetos ambientais conhecidos dos cursistas visando:

a) proporcionar debates quanto a conceitos, principios, pontos positivos e negativos, resultados e outros aspectos;

b) fornecer subsídios para a construção dos projetos.

Procedimentos

- Relato oral dos participantes sobre os projetos.

- Listagem dos projetos em fichas de cartolina.

\section{Desenhando os projetos coletivos}

$\underline{\text { Objetivos }}$

Iniciar o planejamento do projeto de cada equipe de escola

Procedimentos

- Formação de grupos por escola.

- Solicitação para os cursistas idealizarem e debaterem um projeto para suas escolas considerando as atividades anteriores e os demais encontros.

- No transcorrer da atividade o Prof. Marcos, o Coordenador Vitor e a A.T.P. Aparecida percorreram os grupos colaborando com as discussões.

- Para subsidiar os debates o Coord. Vitor foi fixando algumas questões no painel.

- Após 40 minutos de discussões cada grupo apresentou a sua proposta inicial para os demais participantes os quais em seguida comentaram a proposta.

- Na seqüência o prof. Marcos teceu algumas considerações sobre as discussões quanto aos projetos e sobre as propostas de projetos

Resultados e Produtos

- Proposta preliminar de questões básicas para auxiliar a construção de projetos em educação ambiental.

- Transcrição da fala do prof. Marcos Sorrentino sobre as propostas de projetos.

Observações e consideraçōes

As propostas já vinham sendo construídas no transcorrer do curso e em alguns casos antes dele.

\section{Encaminhamentos}

- Foram marcadas reuniões com cada equipe a fim de detalhar as propostas.

- Foi distribuído para avaliação e comentários os textos sobre Educação Ambiental e sobre A Agricultura Hoje, produzidos pelo coordenador a partir das atividades dos encontros anteriores.

\section{$9^{\circ}$ ENCONTRO - Consolidando conceitos sobre E.A.}

\section{Brincando no pátio da escola.}

\section{Objetivos}




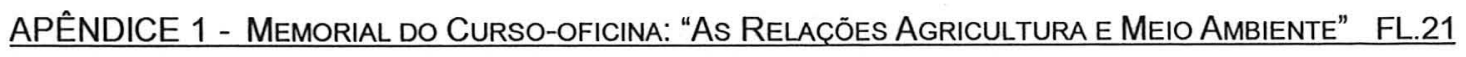

a) Descontrair o grupo;

b) Promover o entrosamento do grupo.

Procedimentos

Solicitação a uma cursista para organizar uma atividade recreativa e de aquecimento com o grupo

Observacōos e considerações

A solicitação para preparar atividades deveria ter ocorrido com antecedência.

O procedimento de participantes prepararem atividades poderia ter sido mais utilizado no transcorrer do curso. Resta saber se os participantes teriam disponibilidade para preparar as propostas e qual seria a recepção dos demais participantes, a tendência seria sempre haver um grupo que já conheceria a atividade.

\section{Avaliando os encontros com a profa. "A" e com o prof. Marcos}

Objetivos

a) Levantar as avaliações dos cursistas sobre $07^{\circ}$ e $\circ 8^{\circ}$ Encontro.

b) Consolidar os eventuais ganhos obtidos durante os encontros.

Materiais: Planilha previamente preparada.

Procedimentos

- Formação de grupos de 3 pessoas.

- Discussão e preenchimento das planilhas de avaliação.

- Exposição dos grupos sobre tópicos de suas avaliações.

Produtos: Planilhas de avaliação e transcrição das explanações

\section{Considerações e debates sobre textos de E.A.}

Objetivos

a) relatar as impressões sobre os textos lidos e resenhados em casa;

b) possibilitar a troca de impressões, o confronto e a busca de consensos em relação ao tema;

c) acrescentar informações e reflexões sobre E.A.

Materiais:

Textos selecionados dos livros da Série Cadernos de Educação Ambiental, publicados pela Secretaria de Meio Ambiente do estado de São Parreira:

(livro 1) Conceitos para se fazer educação ambiental. 1997 e

(livro 2) Em direção ao mundo da vida: interdisciplinaridade e educação ambiental. 1998

Procedimentos

A distribuição dos livros e a indicação dos capitulos a serem resenhados foram feitas em encontros anteriores.

Produto: Fitas cassete e avaliações do coordenador sobre as discussões (apêndice 14).

Observações e considerações

Em função da riqueza do tema e da abordagem desenvolvida nos livros, as explanações foram muito ricas.

\section{Explanação sobre Agenda XXI}

Objetivos

a) apresentar informações sobre a Agenda $X X I$

b) contextualizar e apresentar exemplos de aplicação do conceito de Agenda XXI Local. 
APÊNDICE 1 - MEMORIAL do CURSO-OFICINA: "As RelaçōEs Agricultura e MEIo AmBIENTE" FL.22

Materiais

Cartilha: Agenda XXI do Pedaço preparada pelo Instituto Ecoar de Cidadania. Esta cartilha foi distribuida para cada participante em encontro posterior.

Procedimentos

Explanação oral

Observacõoses e considerações

Posteriormente o conceito de Agenda XXI foi adotado no projeto da Escola 3.

\section{Relato de atividades desenvolvidas por uma cursista}

$\underline{\text { Objetivos }}$

a) apresentar o depoimento de uma cursista sobre a promoção de atividades propostas na Cartilha Agenda XXI do Pedaço em uma Escola.

b) valorizar a iniciativa da cursista - professora.

\section{Procedimentos}

Relato oral feito pela cursista Professora Hortência sobre: as atividades desenvolvidas, as respostas dos alunos e as suas impressões gerais sobre a proposta.

Observacōes e consideraç̃es

A professora demonstrou grande empolgação em função do retorno positivo dos seus alunos. Suas manifestações despertaram interesse dos demais cursistas.

\section{$10^{\circ}$ ENCONTRO - Participação: Homeopata Fernando Bignardi}

Periodo da Manhã: Oficina com o Homeopata Fernando Bignardi

\section{Palestra: Visão Convencional X Visão Alternativa}

\section{$\underline{\text { Objetivos }}$}

Apresentar uma comparação entre os parâmetros convencionais e alternativos de concepção e percepção do mundo, destacando os casos da medicina e da agricultura.

Procedimentos

- Explanações orais e diálogos com a turma.

Produtos: Planilha comparativa entre parâmetros convencionais e altemativos na medicina.

\section{Contando a estória de uma gotinha d'água}

Objetivos

- Reforçar a visão holistica e os conceitos de integração e interdependência dos fenômenos;

- Valorizar a percepção sensorial e a experimentação.

Materiais

Transparências

Fitas e CDs. de músicas para relaxamento e meditação.

\section{Procedimentos}


APÊNDICE 1 - Memorial do Curso-oficina: "As Relaçōes Agricultura e Melo Ambiente" Fl.23

- Narração de uma estória permeada pela apresentação de conceitos e exemplos, através do uso de textos, ilustrações em transparência e música ambiente.

Observações e consideraçōes

O procedimento de contar uma estória emocionou os participantes e foi avaliado como um recurso pedagógico muito rico e interessante.

\section{Exercícios de sensibilização corporal}

Objetivos

Valorizar a percepção, as sensações, a vivência e a experimentação.,

$\underline{\text { Recursos }}$

- Área livre na sala

Procedimentos

- Exercicios de relaxamento.

- Exercícios de percepção corporal.

- Exercício de respiração.

- Exercício de recordação da infância.

- Trocando recordações sobre a infância em duplas.

\section{Considerações gerais}

A proposta de trabalho e percepção de mundo apresentada pelo convidado foi bem recebida pela totalidade do grupo como pode ser observado nas avaliações. Porém um pequeno grupo de cursistas, composto por professores com ampla experiência parece ter sido tocado mais profundamente, tanto é que dois deles tomaram-se clientes do convidado.

Período da Tarde: Oficina com o Coordenador Antonio Vitor

\section{Oficina para detalhamento dos projetos das equipes}

Objetivos

a) Discutir e detalhar as propostas de projetos de Educação Ambiental desenvolvidas por cada uma das equipes;

b) Possibilitar o encontro e participação simultânea de todos os integrantes das equipes.

$\underline{\text { Recursos }}$

- Ante-projetos das equipes;

- Questões propostas pelo coordenador.

Procedimentos

- Debates em grupo considerando as questões apresentadas.

- O coordenador e a A.T.P. Aparecida circularam pelos grupos, levantando questões e aspectos específicos, apresentando sugestões e estimulando os debates. 


\section{$11^{\circ}$ ENCONTRO - Participação: Biólogo GF}

\section{Observando e informando-se sobre a Mata Atlântica}

Objetivos

a) Apresentar noções sobre a vegetação arbórea da Mata Atlântica;

b) Ressaltar a grande biodiversidade da região;

c) Procurar identificar as espécies de árvores predominante nos fragmentos da região.

Procedimentos

- Deslocamento em ônibus até a Reserva do Santuário de São Sebastião.

- Explanações sobre classificações de vegetação arbórea e em especial quanto a Mata Atlântica e sobre procedimentos utilizados para identificação de espécies;

- Caminhada pela Reserva, com o convidado identificando várias espécies e tecendo considerações específicas quanto a usos, nomes populares, condições ambientais associadas, etc.

\section{Levantamento de vegetação arbórea}

Objetivos

a) levantar e registrar os individuos e as espécies arbóreas de uma determinada parcela;

b) executar uma atividade educacional prática envolvendo árvores.

Materiais: - Trena, fitas métrica, barbante, papel, caneta, régua

Procedimentos

- divisão da turma em grupos procurando diversificar as áreas de formação em cada grupo;

- definição de uma parcela $(20 \mathrm{~m}$ x $3 \mathrm{~m})$ para cada grupo;

- levantamento de todas as árvores da parcela que superavam um certo diâmetro;

- registro em croquis das posições dos indivíduos observados.

Produtos: Croquis das parcelas.

\section{Considerações gerais}

Esta atividade foi programada, em parte, devido a demanda dos cursistas quanto a identificação das espécies arbóreas predominante na região. Levando-se em conta: as considerações sobre a grande biodiversidade daquele tipo de mata; as identificações de espécies feitas pelo convidado e mesmo as espécies observadas no exercicio foi possivel perceber dificuldade ou até a inadequação da pergunta quanto a espécies predominantes na região.

Neste encontro a diversidade de formação dos cursistas teve duas implicações importantes: a) As explanações do convidado e mesmo o exercício promovido não foram novidades para os biólogos. b) A atividade prática possibilitou a interação de diversas áreas como: biologia, matemática, educação física e artes.

Em avaliações posteriores foi levantado outro ponto positivo deste encontro envolvendo as relações interpessoais: contatos, conversas, lanche coletivo, auxilios durante a caminhada e o exercicio proposto.

\section{$12^{\circ}$ ENCONTRO}

\section{Participação: Horticultor orgânico G}

\section{Oficina sobre horta orgânica}

\section{$\underline{\text { Objetivos }}$}


APÊNDICE 1 - Memorial do Curso-oficina: “As Relações Agricultura e MeIo Ambiente" FL.25

a) Esclarecer e debater aspectos teóricos sobre hortas orgânicas;

b) apresentar procedimentos práticos para a confecção de uma horta orgânica

c) escolher o local para o preparo da horta da Escola 1

Procedimentos

- Explanações do convidado permeadas por questões dos cursistas.

- Debate envolvendo os cursistas, o convidado e o coordenador.

- Visita a área externa da escola.

Produtos : Transcrição da fita com discussões sobre pontos importantes sobre expansão da agricultura orgânica.

Observações e considerações

A oficina teve um caráter mais teórico em função da indefinição da área, da falta de equipamentos e da necessidade de terra adequada para montagem dos canteiros. $O$ transcorrer dos debates permitiu aflorar uma série de aspectos tanto que estimulam como aqueles que dificultam a agricultura orgânica.

Para suprir certa deficiência que os cursistas sentiam em relação às práticas agrícolas orgânicas específicas, o produtor convidou os cursistas para desenvolverem um estágio em sua propriedade. Tal estágio aconteceu alguns dias depois, contando com a presença de 3 membros da equipe escolar.

O local em que a equipe da escola pretendia montar a horta foi considerado impróprio pelo horticultor, assim foi escolhida uma outra área: maior, plana e com um solo menos contaminado por entulhos. Porém em função de uma série de fatores foi a primeira área que recebeu a horta.

\section{$13^{\circ}$ ENCONTRO - Participação Paisagista P}

\section{Palestra-oficina sobre viveiros para mudas arbóreas}

\section{$\underline{\text { Objetivos }}$}

a) apresentar os elementos básicos teóricos e práticos sobre a montagem de viveiros de mudas;

b) escolher um local para montagem de um viveiro de mudas.

Materiais

- mostruários de sementes;

- areia, solo, humos de minhoca, substrato e outros materiais para viveiros;

- mudas de árvores;

Procedimentos

- palestra -oficina;

- apresentação e exposição de materiais para manipulação dos cursistas;

Observaçōes e consideraçōes

Esta foi a primeira atividade que contou com a presença de estudantes: 6 alunos da escola cujo os professorescursistas pretendiam desenvolver um viveiro.

\section{$14^{\circ}$ ENCONTRO - Participação: Educadora 0}

\section{Apresentação do Vídeo “O Futuro Roubado” (integral)}

\section{$\underline{\text { Objetivos }}$}

Apresentar ou re-apresentar a questão dos impactos relacionados aos produtos e ao modo de vida ocidental moderno. 
154

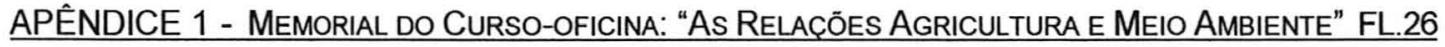

Materiais

- Video: O Futuro Roubado

- Texto sintese do vídeo.

Observações e considerações

A apresentação deste vídeo foi proposta pela educadora $\mathrm{O}$, apesar da grande maioria dos cursistas já ter assistido longos trechos da obra, consideramos interessante re-apresentar o vídeo agora integralmente.

\section{Palestra: "Partir da visão integral da realidade e se preparar para a ação"}

Objetivos

a) Resgatar os princípios da perspectiva holistica e integral;

b) Relacionar esta perspectiva com a educação;

c) Discutir instrumentalização do educador;

Produtos

Sintese da palestra editada pelo coordenador (apresentado a seguir).

Observacões e consideraçöes

Em função do tempo, novamente, foi impossível o aprofundamento do $3^{\circ}$ objetivo da atividade.

O abjetivo geral do desenvolvimento não está sendo: atender as potencialidades e necessidades humanas.

É preciso resgatar o compromisso com a Vida e considerar que a realidade é complexa, dinâmica, diversificada, relacional, ...

Para mudar o Mundo é preciso mudar nossa forma de olhar, conhecer, pensar, sentir,... a realidade.

As açōes de mudança serão mais eficientes quando planejadas a partir da problematização.

Para a resolução de problemas é essencial:

- saber expressá-lo (saber problematizar);

- ter clareza da situação

- articular criatividade e planejamento, assim como, açẫo e reflexão.

No processo educativo é preciso considerar que as pessoas têm formas diferentes dé captar o Mundo.

O educador deve ser um condutor, sensibilizador, possibilitador, instrumentalizador, encorajador, ...

\section{$15^{\circ}$ ENCONTRO - ENCERRAMENTO}

\section{Abertura do evento.}

\section{Objetivos}

a) divulgar e valorizar os projetos das equipes escolares;

b) reconhecer e valorizar a iniciativa da D.E.

c) reconhecer e valorizar o apoio da Prefeitura e suas secretarias no curso e projetos.

Procedimentos 


\section{APÊNDICE 1 - Memorial do CuRso-oficina: "As Relações Agricultura e MeIo Ambiente" FL.27}

- Pronunciamento das autoridades presentes: Supervisor e Representante da Diretoria de Ensino, Vereadores, Secretários Municipais e Prefeito Municipal.

- Apresentação dos coordenadores institucionais do curso: Prof. Marcos Sorrentino (ESALQ-USP) e A.T.P. Benedita Aparecida Barros (Oficina Pedagógica)

\section{Palestra: A expansão da produção orgânica e sua comercialização}

Convidado: Sociólogo Luiz Carlos Trento (Empresa Horta \& Arte)

Objetivos

a) Apresentar um histórico da formação, a situação e as perspectivas de uma das maiores empresas de comercialização de produtos orgânicas;

b) Divulgar e incentivar a produção orgânica na região;

c) Promover uma aproximação entre os setores produtivo e educacional.

Procedimentos

- Palestra na forma de relato e respostas à questões e considerações dos participantes.

Observações e consideraçōes

- O convidado possui uma ótima fluidez na apresentação, dominando o assunto na teoria e na prática, o que tornou a palestra muito agradável e rica.

- Muito interessante foram as intervenções de alguns alunos, colocando suas posições e questionando o preço dos produtos orgânicos.

\section{Apresentação dos projetos desenvolvidos a partir do curso}

\section{Objetivos}

a) Divulgar, valorizar e fortalecer os projetos;

b) Valorizar a iniciativa dos envolvidos;

c) envolver novos parceiros nos projetos (alunos, outras escolas, autoridades, empresas, etc.);

d) contribuir para a avaliação do curso.

Procedimentos

- As equipes constituídas pelos cursistas e demais colaboradores dos projetos de cada escola (professores, coordenadores pedagógicos e representantes dos alunos) foram convocadas.

- Cada equipe teve cerca de 40 minutos para apresentar considerações sobre o planejamento, o desenvolvimento, os resultados e a avaliação de seu projeto.

Produtos:

Fitas de vídeo e transcrição das apresentações das equipes (Apêndice 21)

Observações e considerações

- Esta atividade proporcionou um dos melhores indicadores sobre os resultados do curso e uma excelente fonte de dados e informações para a pesquisa.

- Na avaliação do coordenador: foi um dos momentos mais emocionantes do curso.

- A quase totalidade dos depoimentos dos cursistas foram muito incisivos, emocionados, otimistas, apontando o interesse na continuidade.

- A presença dos alunos foi marcante, os depoimentos emocionaram e valorizaram enormemente os projetos e as iniciativas dos envolvidos. 
156

APÊNDICE 1 - Memorial do CuRso-oficina: "As RelaÇões Agricultura e MeIo Ambiente" FL.28

\section{Mini-palestras com educadores}

Objetivos:

a) Divulgar para os cursistas e outros presentes os trabalhos desenvolvidos pelos convidados;

b) Possibilitar o intercâmbio entre os convidados e os cursistas;

c) Ampliar o leque de parceiros dos projetos das escolas e eventualmente dos trabalhos dos convidados;

Procedimentos

Educadores que desenvolvem trabalhos com meio ambiente na região realizaram palestras de aproximadamente 30 minutos com um pequeno intervalo para questões dos participantes:

- Enga Jussara Carvalho - Coordenação do Comitê de Bacias do Médio Tietê e Sorocaba

Tema: Os comitês de bacia e a gestão das águas.

- Educadora O Serrano

Tema: Projetos Ambientais na Reserva da Biosfera do Cinturão Verde de S. P.

- Jornalista Isabel Issler

Tema: Uma iniciativa de Ecoturismo em Ibiúna.

\section{Debate: Educação e desenvolvimento sustentável em lbiúna}

Objetivos

a) possibilitar o relacionamento entre os diretamente envolvidos com os projetos (cursistas, apoiadores e alunos) e os palestrantes, as autoridades e os demais convidados.

b) promover encaminhamentos para continuidade dos projetos ou para de novos projetos

Procedimentos

Debate livre entre os presentes.

Observacōes e consideracões

A atividade iniciou-se no fim da tarde, os participantes estavam cansados.

A participação e os temas ficaram centrados nos convidados. $O$ enfoque ficou nas questões ambientais da região e a perspectiva educacional foi pouco abordada. 
APÊNDICE 1 - Memorial do CuRso-oficina: "As Relacōes Agricultura e MeIo Ambiente" FL.29

\section{COMENTÁRIOS SOBRE ALGUNS ASPECTOS DO CURSO}

\section{AS DINÂMICAS}

Na medida do possivel procurou-se promover atividades considerando que os cursistas eram educadores. A intenção geral sempre foi desenvolver atividades e dinâmicas variadas que atendessem os objetivos do curso e da pesquisa mas que também permitissem aos professores participantes algum tipo de adaptação destas a suas práticas escolares.

Os principais procedimentos foram: explanações do coordenador, palestras e oficinas com especialistas, vivências e visitas complementadas com relatórios, atividades de arte-educação, leituras extraclasse com resenhas comentadas, videos, pesquisas extraclasse, avaliações e auto-avaliações, produção coletiva de textos, atividades em grupo, caminhadas, brincadeiras e outras.

\section{OS CONVIDADOS}

A participação de diversos especialistas promovendo palestras, oficinas e outras atividades foi um dos pontos mais positivos do curso, possibilitando o contato com diversas visões, distintas mas convergentes. A promoção de momentos de avaliação, que muitas vezes aconteceram em encontros posteriores, possibilitou consolidar e enriquecer as experiências com os palestrantes. Todas as palestras foram precedidas de reuniões e conversas telefônicas com os convidados para acertos prévios sobre a programação.

Diversos contatos e laços pessoais foram construídos entre os participantes e os palestrantes destacando-se:

- a) Convites para a educadora $\mathrm{O}$ e o produtor $\mathrm{G}$ para realizarem palestras em outras escolas.

- b) Trocas de correspondência entre a cursista Flora e a palestrante Profa Dr. "A".

- c) Indicação do nome do paisagista Petter à Prefeitura Municipal para desenvolvimento de atividades.

- d) Duas cursistas tornaram-se clientes do médico homeopata Fernando Bignardi.

\section{LEITURAS E RESENHAS}

As solicitações de leitura geralmente foram atendidas pela quase totalidade dos cursistas. Porém outros textos ou os livros distribuídos foram pouco consultados provavelmente por dois fatores principais: falta de tempo e falta de hábito de leitura.

A quase totalidade das resenhas apresentadas se restringiu a destacar tópicos dos textos, muitas vezes reproduzindo trechos. Apenas um cursista procurou dialogar com os textos. Este tipo de procedimento precisa ser exercitado, uma forma possível e talvez recomendada seria a formação de duplas para a discussão de textos curtos em sala de aula. 
158

APÊNDICE 1 - Memorial do CuRso-oficina: "As Relações Agricultura e Meio Ambiente" Fl.30

\section{CONSTRUINDO PROJETOS}

A construção de propostas de projetos educacionais se deu desde o primeiro contato entre a turma e o coordenador:

- O cartaz de divulgação do curso já fazia referência ao fato de que durante o curso haveria um exercício de produção de propostas educacionais.

- Na palestra de divulgação do curso foi explicitado a intenção de estimular a formação de propostas dos cursistas.

- No módulo 1 foi distribuído um projeto para leitura e discussão entre as equipes escolares.

- No segundo módulo o encontro com o convidado Prof. Marcos foi dedicado quase exclusivamente à discussão sobre projetos de E.A. Também neste módulo solicitado aos cursistas a leitura de textos que tratavam de modalidades de projetos em E.A., os quais posteriormente foram relatados e discutidos .

- No terceiro módulo, concomitante às oficinas temáticas, aconteceram reuniões de detalhamento dos projetos com o coordenador do curso.

- Seguindo a programação, no quarto módulo as equipes concentraram os esforços no desenvolvimento dos projetos. O coordenador acompanhou várias reuniões com as equipes ou representantes para detalhamento de atividades, avaliações e re-adequações. Neste módulo o coordenador também participou de diversos eventos específicos de cada projeto e também de eventos de divulgação dos trabalhos.

Considerando a sobrecarga de trabalho que os cursistas poderiam enfrentar em função dos demais projetos promovidos pela Oficina Pedagógica foram feitas contatos no sentido de incorporar os projetos decorrentes do curso à programação da D.E. e inclusive articulá-los com outros projetos.

\section{REUNIÕES PARA DETALHAMENTO DOS PROJETOS}

Após o encontro com o professor Marcos aconteceram diversas reuniões com as equipes em cada escola visando detalhar os projetos. Este processo foi muito rico para a pesquisa e creio que também foi para os participantes. Um aspecto que se destacou foi quanto a dificuldade generalizada dos professores-cursistas em formularem projetos e em especial de projetos educacionais consistentes e factiveis..

Dois aspectos se repetiram nas quatro equipes, durante o processo inicial de detalhamento de projetos.: Por um lado uma grande valorização das ações a serem desenvolvidas e a preocupação com as técnicas e procedimentos associados a estas ações. Por outro lado uma grande dificuldade de explicitar os objetivos educacionais das propostas.

Considerando as dificuldades acima citadas e como estratégia para melhor ordenamento das discussões e visualização dos procedimentos foi proposto às equipes uma série de questões apresentadas em textos que abordavam a formulação de projetos. Este procedimento desenvolvido no transcorrer do processo (durante as primeiras reuniões) facilitou os trabalhos e permitiu limitar e focalizar as discussões do grupo. Considerando o retorno deste procedimento, 0 coordenador organizou, posteriormente, uma Proposta de Questões Referenciais (ou subsidiárias) para a montagem de projetos em educação ambiental.

Estas reuniões facilitaram o contato direto com os quadros de cada escola, possibilitando uma maior aproximação com as direçães e professores não cursistas e a incorporação de novos participantes nos projetos e mesmo no curso. Destacam-se os casos de um coordenador pedagógico e de um professor da Escola 1 que se integraram plenamente à equipe do projeto além de outra professora que várias vezes participou das reuniões opinando e oferecendo auxilio; de um professor da Escola 2 que tornou-se cursista e da coordenadora pedagógica da Escola 4 que participou de reuniões de detalhamento do projeto e de um encontro do curso.

A dificuldade dos participantes de formularem projetos indica que provavelmente estes educadores apresentam dificuldades de trabalharem projetos com os educandos.

Duas preocupações aventadas por todas as equipes foram: a necessidade e interesse em desenvolver propostas que tivessem efetiva implementação e que possibilitasse continuidade, seja através do próprio projeto ou de novos.

O trabalho com a equipe da Escola 2 levantou uma questão importante quanto aos procedimentos para a construção das propostas de projetos por nós adotados (ver relatório do encontro com o Prof. Marcos). Partindo dos sonhos 
APÊNDICE 1 - Memorial do CuRso-oficina: "As RelaÇōes Agricultura e MeIo Ambiente" FL.31

do grupo fui, através de questões específicas, estimulando a reflexão sobre as limitações impostas ao grupo, o procedimento levou a equipe a promover alterações na proposta inicial implicando na adequação dos objetivos . Esta situação gerou certa frustração em alguns membros da equipe. A questão que fica é como estimular os sonhos, a criatividade e a empolgação dos educandos e articulá-los com propostas viáveis. Ou em outras palavras: como articular os sonhos com as limitações e dificuldades. Como o educador pode evitar ou pelo menos reduzir este sentimento de frustração? Posteriormente refletindo sobre esta situação conclui que provavelmente um trabalho prévio sobre o conceito de prioridade poderia ter ajudado a reduzir a frustração.

O procedimento de reuniões e acompanhamento da construção da proposta foi reconhecido pelos cursistas como positivo, o que levou uma cursista a fazer o seguinte comentário:

- "Os professores gostam de você pois sentem-se amparados, você está presente e mostra-se preocupado". (Caderno de pesquisa 10/07/99)

Duas equipes (Escolas 3 e 4) apresentaram propostas que foram identificadas como preparatórias ou seja que contribuiriam para outras propostas futuras.

A questão de ocorrerem dificuldades para implementação das propostas foi assumido pelas quatro equipes como um desafio, quase um motivador. Neste sentido a Equipe E1 avaliava que teria dificuldades técnicas e carência de uma área para desenvolver a proposta, a Equipe E2 apesar de prever dificuldades institucionais insistiu na proposta, a Equipe E3 mesmo reconhecendo a limitação do quadro (uma coordenadora e dois professores) se propôs a trabalhar com todas as turmas da escola e a Equipe E4 optou por trabalhar uma classe considerada problemática.

Algo observado em alguns projetos foi que provavelmente devido às dificuldades de verbalização e de redação, além das deficiências de anotações durante as reuniões de detalhamento ocorrereu a produção de textos de projetos com grande componente pessoal do redator e ou a desconsideração ou a ausência de importantes aspectos discutidos nas reuniões .

\section{REUNIÃO COM A EQUIPE E3}

A primeira reunião para detalhamento do projeto foi feita com a equipe da Escola 3 composta por dois professores e uma coordenadora pedagógica. Devido a indisponibilidade de tempo dos membros, a reunião foi de curta duração e aconteceu em parte durante o HTPC (horário de trabalho pedagógico coletivo).

Na reunião os professores tomaram a justificar a proposta, lembrando os problemas relacionados a higiene e limpeza e ressaltando a questão da baixa sensibilidade dos demais professores para as questões ambientais.

No geral, as colocações sobre o projeto apontavam para a promoção de uma série de atividades e eventos que apresentavam uma pequena articulação efetiva, implicando num certo distanciamento em relação aos objetivos gerais. No intuito de enriquecer a proposta e considerando o esboço apresentado em encontros anteriores, a dificuldade de formulação dos tópicos do projeto e a falta de tempo para a reunião, apresentei à equipe o conceito de "Agenda 21 do Pedaço" utilizando algumas cartilhas informativas sobre o tema organizadas pelo Instituto Ecoar pela Cidadania.

A segunda reunião aconteceu uma semana depois com a presença dos dois professores da equipe. Neste intervalo uma das professoras desenvolveu uma das atividades propostas na cartilha da Agenda 21 do Pedaço com uma de suas turmas e tendo inclusive a oportunidade de relatar a experiência durante um encontro do curso que também ocorreu neste período. Provavelmente em função da experiência com turma a professora se apresentou mais entusiasmada que o costumeiro, trazendo diversas propostas por escrito, o outro professor também se mostrou muito entusiasmado. Segundo algumas afirmaçöes dos professores o entusiasmo devia-se ao fato da proposta de Agenda 21 Local contemplar algumas de suas idéias e anseios.

Esta equipe, como as demais, apresentou dificuldades de explicitação dos objetivos que eram confundidos com ações propostas, procedimentos, etapas, etc. Em função do pouco tempo disponivel o coordenador adotou uma postura de maior diretividade nos trabalhos, apressando o procedimento adotado com as demais equipes de estimular o debate e a reflexão através da apresentação de questões específicas. Mesmo assim várias aspectos foram debatidos e diversas anotações foram feitas. No dia seguinte a professora que integra a equipe entregou-me a primeira versão do projeto, porém notei que não constavam alguns elementos e aspectos tratados em reuniões e encontros anteriores. 


\section{REUNIÕES COM A EQUIPE E2}

A primeira reunião com a equipe da Escola 2 contou com a presença de 6 pessoas mais 1 pessoa (periodo parcial) . Em todas as reuniões com este grupo houve grande dificuldade de determinação de um horário que contemplasse todos os cursistas envolvidos, os principais motivos seriam:

- elevado número de participantes; - inflexibilidade da grade horária; - compromisso profissional em outras escolas; compromisso pessoais.

As considerações iniciais da equipe esboçavam uma proposta abrangente e de longo prazo que exigiria muita dedicação dos participantes, implicando numa grande dificuldade de implementação. Havia o desejo entre vários cursistas de desvincular os trabalhos da escola e criar um grupo de jovens e adultos que trabalharia a proposta.

Partindo da avaliação desta proposta que já se esboçara em encontros anteriores, procurei estimular as reflexões e o reconhecimento por parte da equipe quanto as dificuldades a serem enfrentadas e a necessidade de limitar a proposta. Este processo de limitação e formatação da proposta foi qualificado como "tortura" por diversos membros da equipe. Mas posteriormente houve o reconhecimento pelos cursistas quanto a validade das preocupações levantadas e quanto a este procedimento.

Outro aspecto que se destacou na primeira reunião foi a dificuldade dos participantes de definir os objetivos gerais e educacionais da proposta, associada a uma dificuldade ainda maior em verbalizá-los. O que ocorria era uma grande confusão entre objetivos e ações ou procedimentos. Para facilitar os trabalhos fomos adaptando e seguindo parcialmente um conjunto de questões apresentadas no Guia para Elaboração de Projetos do NEPAMMWF. (XXX) 0 procedimento era: Uma questão era apresentada, após discussões e formação de consenso os resultados eram anotados pelos cursistas na folha especifica para aquela questão. Eventualmente as discussões retornavam às questões já trabalhadas gerando novas anotações nas respectivas folhas. Após a reunião digitei o texto procurando ser o mais fiel às anotações.

Também merece destaque a preocupação da equipe em garantir a execução do projeto naquele período letivo e a continuidade do projeto para outros anos.

A versão inicial deveria ser usada para novas discussões e reformulações pela equipe, porém em função da necessidade de apresentação de uma proposta à Prefeitura Municipal, redigi uma segunda versão (apêndice 23) procurando considerar as minhas observações quanto as expectativas do grupo, mas também procurando aprimorar a apresentação do projeto diante dos possiveis parceiros. Nesta nova versão: a) realizei uma separação entre objetivos gerais e especificos; b) substitui o termo: "projeto educacional" por: "componente educacional de um programa de valorização e incentivo ao plantio de árvores..." ; c) acrescentei algumas palavras ao texto a fim de esclarecer a proposta; d) propus o título ao projeto.

Durante as reuniões tornou-se mais explicito as diferenças de interpretações e mesmo de objetivos dos cursistas. Isto me remeteu a reflexão das dificuldades impostas aos professores ao trabalharem com projetos junto a classes que variam de 35 a 45 alunos. Como respeitar as diferenças e resgatar as convergências?

\section{REUNIÃO COM A EQUIPE E4}

A reunião com a dupla de professores cursistas desta escola contou com a presença da assistente técnicopedagógica da Diretoria de Ensino e da coordenadora pedagógica da escola, as quais contribuiram para enriquecer o debate e a proposta.

Os professores reconheciam uma série de dificuldades para o desenvolvimento do trabalho, tais como: pequeno número de educadores envolvidos, falta de tempo dos membros da equipe e dificuldade em articular a proposta ao programa escolar pré estabelecido. Mas a despeito destas constatações, os envolvidos afirmavam o interesse em imprimir um tratamento aprofundado ao projeto, neste sentido decidiu-se por formular uma proposta que não fosse muito ampla e que abarcasse lugares e temas específicos. 


\section{APÊNDICE 1 - Memorial do CuRso-oficina: "As Relaçōes Agricultura e MeIo AmBiente" FL.33}

Inicialmente escolheu-se como foco no projeto uma turma da segunda série. A escolha foi justificada por ser a turma do antigo curso de magistério e portanto composta por potenciais educadores ambientais e pelo desafio de trabaIhar com uma turma considerada problemática pela equipe.

No transcorrer das discussões e considerando-se a turma escolhida foi configurando-se a proposta de trabalhar e valorizar a cooperação, as relações interpessoais e a formação de equipes de educandos.

Um fato interessante desta equipe foi a decisão de aproveitar, na redação da proposta do projeto, partes do texto coletivo produzido pelos cursistas.

Esta equipe foi a que exigiu menor número de reuniões (apenas uma) para chegar a uma proposta inicial completa, isto provavelmente se deve ao número reduzido de debatedores e as intervenções da A.T.P. e da coordenadora pedagógica da escola.

\section{REUNIÕES COM A EQUIPE E1}

A equipe era composta pelos 4 cursistas que lecionavam nesta escola, pelo coordenador pedagógico e por um professor não cursista mas que possuia alguma experiência agricola e interesse em agricultura orgânica. As reuniões de formulação do projeto contou com 3 dos 4 cursistas e com o coordenador pedagógico, além disso teve algumas intervenções de mais uma professora não cursista e do vice-diretor da escola.

Desde a primeira reunião os membros da equipe da Escola 1 declararam dificuldade para elaboração de projetos, especialmente no detalhamento de tópicos como: objetivos, metodologias, cronograma, etc. Considerando isto e a experiência em atividade semelhante com duas outras equipes, procurei orientar as discussões a partir de adaptações das questões apresentadas no Guia para Elaboração de Projetos do NEPAMMWF. Este procedimento se mostrou útil aos trabalhos, ordenando e pontuando as discussões.

Muito significativas foram as considerações de um dos membros quanto aos objetivos gerais do projeto: "incentivar nos alunos uma nova forma de perceber" que agregue o "amor a vida" e que implique em "mudanças de posturas". Creio que grande parte deste repertório foi construído através do curso.

A escola só possuía turmas de ensino médio no período noturno, considerou-se que a montagem de uma horta neste periodo seria dificil. Assim foi escolhida uma turma de $6^{\text {a }}$ série do ensino fundamental que era atendida pelos 3 professores envolvidos.

Nas reuniões surgiu a idéia de escolher alguns educandos como monitores para o trabalho de confecção e manutenção da horta, inclusive foi apontado o nome de um determinado aluno para esta função.

Também foi discutido a eventual necessidade de uma área externa a escola para montagem da horta, neste sentido a equipe recebeu o apoio do vice-diretor que se comprometeu a procurar áreas vizinhas se necessário.

Um problema observado e talvez associado à deficiência nas anotaçōes e registros do grupo foi a perda de uma parte das comentários, conceitos, propostas e decisões desenvolvidas durante as reuniões e que não foram incorporadas à versão escrita do projeto. 
APÊNDICE 1 - Memorial do Curso-oficina: "As Relacões Agricultura e MeIo Ambiente" FL.34

\section{OS PROJETOS}

\section{PROJETO HORTA ORGÂNICA - LABORATÓRIO VIVO (EQUIPE E1)}

Alguns professores e o coordenador pedagógico desta escola já planejavam montar uma horta, o que curso provocou foi a incorporação da idéia de agricultura orgânica.

Durante as reuniões procurei ressaltar e estimular os membros da equipe a atentarem para os aspectos educacionais da proposta, a mudança do nome do projeto foi uma conseqüência desta postura de procurar valorizar o componente educacional para além da ação prática a ser desenvolvida. O termo "laboratório vivo" foi cunhado pela equipe porém não foi totalmente incorporado conforme pode ser observado no material de divulgação sobre o projeto distribuído no encontro de encerramento.

Devido a relativa disponibilidade de tempo para cuidar de projetos em decorrência de sua função, o coordenador pedagógico da escola foi um membro importante nesta equipe apresentando intensa participação e várias contribuições, sendo ele responsável pela redação da proposta do projeto. No entanto este membro não participou do curso o que implicou em não passar por vivências, leituras, palestras, debates, reflexões e tudo mais que os cursistas tiveram acesso durante os 4 meses que antecederam a formulação dos projetos, creio que isto implicou em um certo desalinhamento entre as posturas dos cursistas da equipe e os textos produzidos pela equipe incluindo a proposta de projeto.

O desenvolvimento do projeto acompanhou as etapas propostas inicialmente, porém alguns procedimentos não foram praticados.

A área inicialmente reservada na escola para a montagem da horta foi contra-indicada pelo produtor que assessorou o grupo. Assim foi escolhida outra área, porém devido a uma série de circunstâncias incluindo: falta de materiais de trabalho, dificuldade de proteção da área escolhida e resultados positivos apresentados por algumas mudas de hortaliças plantadas na área inicialmente reservada levou a equipe a adotar esta área. Observação: o plantio das primeiras mudas foi feito sem o conhecimento prévio da equipe por uma servente da escola, a qual se tornou uma das protetoras da horta.

O contato da turma de estudantes escolhida com o assunto iniciou-se já no mês de junho por conta da preparação da "Sala sobre Agricultura" exposição montada para a Mostra Ecológica. A partir de agosto intensificou-se o tratamento sobre $o$ assunto em sala de aula. Foram promovidas duas reuniões com a autoridades da Prefeitura visando obter os instrumentos (enxadas, pás, etc.), os materiais para a cerca de proteção, as análises de solo e a terra apropriada. Apesar da boa vontade apresentada pelas autoridades nenhum recurso efetivo foi obtido por esta escola.

\section{- Preparação do terreno e plantio}

A demora em iniciar as atividades práticas e a cobrança que passou a ser feita por alguns alunos implicaram na geração de desconforto e ansiedade entre os membros da equipe. Neste sentido a equipe decidiu iniciar os trabalhos contando com os recursos disponiveis na escola: instrumentos e mudas foram trazidos por professores e alunos. Um mutirão de trabalho em menos de três dias limpou o terreno, organizou os canteiros, plantou as mudas e semeou. Posteriormente os serviços de manutenção da horta continuaram a ser feitos por alunos e professores.

\section{- Reunião de avaliação do andamento do projeto (17/11/1999)}

Segundo os professores vários vizinhos da escola se mostraram curiosos e interessados com a horta e passaram a acompanhar o crescimento dos cultivos.. Neste dia registrei dois fatos relacionados a isto: a) duas senhoras que caminhavam nas proximidades da escola, atravessaram a rua para observar os trabalhos desenvolvidos na horta; b) um adolescente morador da região, mas aluno de outra escola, que acompanhava e até colaborava com os trabalhos.

A reunião, como outras nesta escola, se caracterizou pelo rodizio de participantes, isto se deve ao fato que os professores comparecem durante "janelas" entre aulas e o coordenador pedagógico possuir uma série de demandas.

Iniciada a reunião o coordenador pedagógico afirmou que apesar dos ganhos o projeto era um "experimento limitado", porém não foi possivel um aprofundamento da de sua avaliação. 
Uma das professoras relatou que seu pedido para os alunos trazerem esterco e adubo vegetal foi prontamente atendido e ressaltou o envolvimento dos alunos:

"- É impressionante a mobilização dos alunos."

Outros professores e funcionários da escola (serventes e inspetores de alunos) se envolveram e passaram a trabalhar no projeto. O professor de história pintou o muro da área da horta, a professora de língua estrangeira prontificou-se a montar painéis de identificação em inglês dos cultivos e dos instrumentos. Alunos de outras turmas começaram a solicitar a participação no projeto. Alguns pais de alunos também se ofereceram para colaborarem com o projeto. Observei um depoimento espontâneo e entusiasmado de um aluno para sua mãe aproximadamente nos seguintes termos:

- "Mãe, a minha escola está diferente, tem uma horta lá, hoje a professora levou a gente para ver, foi legal !".

Outra professora (não cursista mas colaboradora ativa do projeto) foi categórica:

"- Achamos um jeito de trabalhar aqueles alunos dificeis."

No caso a professora se referia aos alunos muito indisciplinados que tumultuavam as aulas e aqueles que ficavam no pátio da escola sem ingressarem nas salas. O procedimento adotado foi atribuir a estes alunos a atividade de rega e limpeza da horta. Segundo testemunho de diversos professores e mesmo pelo acompanhamento destas atividades o pude notar que os resultados quanto redução da indisciplina estavam sendo muito positivos.

Os membros da equipe e outros professores colaboradores apontaram diversos pontos positivos relacionados à implantação da horta destacando-se: valorização do trabalho manual como elemento de redução da agressividade e aumento da concentração; maior participação e interesse nas aulas; aumento do respeito e aproximação entre alunos e professores.

Além da carência de materiais básicos para o trabalho ( enxadas, terra com matéria orgânica, etc.) outros problemas enfrentados por esta equipe no desenvolvimento do projeto foram:

- dificuldade de operacionalizar os trabalhos com turmas de até 45 alunos, falta de espaço e dificuldades para dividir e controlar as tarefas.

- falta de tempo de alguns professores devido a outras demandas como: atuação sindical, faculdade, problemas familiares, etc.

\section{PROJETO VALORIZANDO AS ÁRVORES EM NOSSO MUNICÍPIO - EQUIPE E2}

Associadas a este projeto foram desenvolvidas uma série de atividades, sendo a maioria com a participação dos alunos e em locais externos a escola.

- Visita ao Parque Estadual do Jurupará

Promovida por uma equipe de jipeiros e com os apoios da Prefeitura Municipal e de uma viação de ônibus local. Participaram da atividade de observação e vivência no Parque do Jurupará: 7 cursistas da escola, 2 professores não cursistas, o esposo de uma cursistas e 10 alunos convidados oriundos de 2 duas turmas previamente selecionada.

Nesta atividade caracterizada pela informalidade, é possivel identificar diversos ganhos cognitivos, afetivos, existenciais, profissionais, ... enfim: educacionais, se forem considerados aspectos como:

a) as trocas interpessoais entre os professores e a conseqüente contribuição a consolidação da equipe;

b) a aproximação entre professores e alunos, em uma situação de menor peso dos papeis de cada um;

c) a observação da disciplina e do espirito de equipe entre os jipeiros;

d) a observação e a vivência num ambiental natural;

e) o reconhecimento de uma importante e extensa área do municipio;

f) a relação entre a área visitada e o projeto da equipe;

g) a execução de relatórios e avaliações posteriores.

Este evento foi um marco na consolidação do envolvimento dos participantes, do fortalecimento da equipe e da empolgação com o desenvolvimento de trabalhos com os estudantes. 
164

APÊNDICE 1 - Memorial do CuRso-oficina: "As Relacões Agricultura e MeIo Ambiente" Fl.36

- Visita ao Parque Municipal Chico Mendes e à sede da Polícia Florestal (Sorocaba) (19/08/1999)

Esta atividade dirigida a estudantes contou com a participação de 20 alunos do período matutino (metade da turma do $2^{\circ} \mathrm{A}$ ) e 20 do período vespertino (metade da turma do $2^{\circ} \mathrm{B}$ ) acompanhados por 2 professores cursistas (escoIhidos pela diretora da escola) e pelo coordenador do curso. O deslocamento ocorreu em ônibus cedido pela Prefeitura Municipal. A programação foi composta por: palestra sobre legislação ambiental proferida por um policial florestal, lanche comunitário, passeios pelo parque em áreas de vegetação em recuperação, brincadeiras ao ar livre, grupo de discussão com os estudantes sobre o projeto.

Durante a palestra foi possivel observar grande interesse dos ouvintes, principalmente quanto a questões que Ihes diz diretamente respeito como: posse de animais e desmatamento com finalidade agricola. Em avaliações posteriores verificou-se que apesar de seu enfoque básico e pouco aprofundado a palestra provocou relativo impacto em muitos estudantes participantes.

As colocações dos estudantes durante o grupo de discussão indicaram o interesse no desenvolvimento do projeto proposto pelos cursistas e a valorização de atividades extraclasse e extramuro escolar, ressaltando que o processo precisa ser "gostoso" ou "legal". Os alunos apresentaram várias idéias de trabalhos, lugares, temas de pesquisas e apontaram como caminho para ampliação do projeto: "despertar a curiosidade dos alunos", mas também enfatizaram que a entrada no projeto deve ser feita com "compromisso".

Na ocasião observei a falta de experiência dos professores em estimular a participação dos alunos e uma ansiedade para expor análises e propostas, demonstrando uma dificuldade de adoção de uma postura menos diretiva. Uma dificuldade minha foi: como abordar este aspecto com os professores, de maneira a contribuir para a construção de novas posturas e repertórios?

- Visita ao viveiro da empresa Furnas Centrais Elétricas

Nesta atividade, providenciada e acompanhada pelo secretário municipal de agricultura de lbiúna, o grupo foi composto por 3 cursistas, a diretora da escola e o coordenador do curso. Graças aos esforços do senhor secretário e a atenção que o grupo recebeu por parte da direção da empresa, os objetivos gerais foram alcançados, a saber: conhecer a estrutura e o funcionamento de um viveiro de mudas de árvores, solicitar a doação de mudas e promover contatos para futuras parcerias.

Destaca-se nesta atividade a possibilidade dos cursistas observarem a simplicidade de um viveiro mesmo numa grande empresa como a visitada.

- Cerimônia de lançamento do projeto (02/09/1999)

Este evento, organizado e programado pela senhora diretora da escola, teve como objetivo marcar oficialmente 0 lançamento do projeto e foi composto por:

- pronunciamentos de: autoridades municipais (secretários, vereadores e prefeito), representantes de órgãos estaduais (CATI, Policia Florestal e Delegacia de Ensino), representante da empresa Furnas Centrais Elétrica

- apresentação de músicas,

- plantio de árvores nas dependências da escola

As atividades contaram com a participação dos alunos do período matutino que assistiram aos pronunciamentos e apresentações e colaboraram no plantio das árvores. Os alunos colaboraram no preparo prévio das covas e da terra adubada.

$\mathrm{Na}$ ocasião os cursistas consideraram positiva a iniciativa da diretora enquanto uma forma de envolvimento e comprometimento desta para com o projeto. Porém avaliações mais detalhadas indicaram um descontentamento com os procedimentos adotados na organização os quais geraram um sentimento de marginalização da equipe.

- Levantamento da Arborização Urbana (02/09/1999)

Organizado pelos cursistas como atividade associada ao lançamento do projeto, o levantamento da arborização urbana de Ibiúna visava:

- envolver todos os estudantes do periodo vespertino em uma única atividade;

- envolver os professores não cursistas no projeto; 


\section{APÊNDICE 1 - Memorial do Curso-oficina: “As Relaçōes Agricultura e Meio Ambiente” FL.37}

- levantar a situação da arborização nas ruas do núcleo principal da cidade, criando uma base de dados sobre número de indivíduos, espécies e localização das árvores.

O procedimento foi o seguinte:

- Partindo de um mapa geral a cidade foi dividida em pequenas áreas englobando algumas ruas;

- cada turma acompanhada por dois ou três professores se encarregou do levantamento da situação de uma das áreas em que a cidade foi dividida;

- identificação das espécies e localização das árvores em relação ao traçado das ruas;

- Registro dos dados em croqui da área fornecido previamente ou em planilhas propostas pela turma.

Considero que este evento teve algumas falhas que implicaram em problemas para os envolvidos: falta de informação dificultando a compreensão da proposta e dos procedimentos; dificuldades de localização e de trabalho com os croquis e mapas e dificuldade na identificação das espécies.

Creio que para esta atividade era necessário a promoção de uma atividade piloto com os cursistas para verificação das dificuldades e exercício de técnicas específicas, como leitura de mapas e identificação de espécies).

- $1^{a}$ Reunião Geral da equipe para acompanhamento do projeto.

Esta atividade reuniu todos os cursistas da escola e teve os seguintes objetivos:

- avaliar o Evento de Lançamento e a atividade de levantamento da arborização urbana;

- discutir e deliberar sobre o encaminhamento do projeto;

- deliberar sobre a participação no evento EXPAl;

- conversar com o Sr. Bill coordenador do grupo de jipeiros que promoveu a visita ao Parque Jurupará. No caso tratou-se sobre a situação do parque e sobre eventuais parcerias com sua empresa de turismo ou com os jipeiros.

Um dos encaminhamentos foi a proposta de realização no Dia da Árvore de atividades de divulgação do projeto e eventualmente aplicação de questionários sobre arborização. Sendo que o Sr. Bill se prontificou a patrocinar materiais para o evento.

$2^{a}$ Reunião Geral da equipe sobre o andamento do projeto

Contando com a presença de 8 dos 10 membros da equipe este encontro foi proposto pelo coordenador do curso, considerando a frustração do grupo quanto a não implementação do viveiro. Os objetivos eram:

- Avaliar a situação do projeto. Para subsidiar esta empreitada foi entregue um texto provocativo na semana anterior .

- Discutir e propor encaminhamentos para o fechamento do projeto no semestre.

Nesta ocasião ficou claro o desapontamento dos participantes diante da não realização de ações efetivas propostas inicialmente incluindo: montagem de um viveiro, plantio de árvores e envolvimento efetivo dos alunos.

As consideraçöes variaram de uma postura negativista do tipo:

"Estou desanimado, enquanto não houver o plantio de árvores o projeto não aconteceu."

"Tanta festa mas não aconteceu na realidade."

Até avaliações otimistas como:

"Lançamos uma semente, marcamos os alunos que participaram".

"Valeu a pena pois nos aproximou das questões ambientais"

Todas as avaliações apontaram como principal obstáculo ao desenvolvimento do projeto a falta de autonomia do grupo, da mesma forma todos expressaram o desejo de que o projeto tenha continuidade.

As diferenças de interpretações e de perspectiva diante da educação podem ser notadas facilmente nas colocaçöes dos participantes. Apesar de um certo destaque quanto a açöes efetivas, também ocorreram algumas colocações relativas à formação dos estudantes.

Como forma de fortalecer o projeto e satisfazer parte da ansiedade do grupo quanto a ações práticas com os alunos foi proposto uma atividade especifica com os alunos. No detalhamento desta proposta optou-se por trabalhar a sensibilização; o sensorial, o afetivo e o racional. 
APÊNDICE 1 - MEMORIAL do CURSO-OFICINA: "As RelAÇÕEs AgRICULTURA E MEIO AMBIENTE" FL.38

\section{PROJETO NOSSO MEIO AMBIENTE ESCOLAR - EQUIPE E3}

\section{Atividades}

- Gincana do Meio Ambiente na Escola

A Gincana do Meio Ambiente fazia parte da programação do projeto da Escola 3, o objetivo era trabalhar com todos os alunos dos períodos matutino e vespertino. Optou-se por aproveitar um dia de reposição de aulas aos sábados para desenvolver a gincana, porém devido a dificuldade de transporte aos sábados enfrentada por muitos alunos e ao boicote de outros, o número de alunos presentes foi muito pequeno. Assim a equipe decidiu executar apenas algumas atividades programadas para o dia.

Foram desenvolvidas atividades como: concurso de frases sobre meio ambiente (Apêndice 23) e concurso de cartazes sobre meio ambiente.

Comentários: Um dos principais problemas era o recinto muito dispersivo. Também observei a falta de experiência dos professores para uma abordagem educacional menos diretiva e mais provocativa e para o tratamento de questões ambientais. Quase todas atividades ressaltavam a competição inter-grupos e a colaboração intra-grupo. $\mathrm{O}$ coordenador reproduziu as frases visando resgatar e valorizar o trabalho. Atividades com mais de 100 participantes, constituem-se em momentos de grande dificuldade para os educadores .

- Apontando as Alegrias e Lamentações quanto a escola (30/08/1999)

Os alunos foram conduzidos turma por turma (totalizando 25 turmas) a uma sala previamente preparada, dividida em duas partes:

Metade A: apresentava: chão varrido, materiais limpos e em bom estado de conservação, carteiras arrumadas e painéis nas paredes

Metade B: apresentava: chão sujo (papéis, latas, etc.), carteiras bagunçadas e materiais sujos, pichados e quebrados.

Após a turma transitar pela sala e observar o espaço, um professor da equipe lembrava que aquilo tudo fazia parte do ambiente escolar e questionava os alunos quanto as suas opiniões diante das duas situações reproduzidas na sala.. Após algumas manifestações o professor tecia considerações sobre os responsáveis por aquela situação incluindo os alunos, a administração da escola e os governos (principalmente o estadual). Em seguida solicitava-se que a turma voltasse para a sua sala, discutisse e apontasse três aspectos positivos e três aspectos negativos do ambiente escolar.

Posteriormente os três aspectos positivos e os três negativos de cada turma foram agrupados respectivamente no "Muro das alegrias" e no "Muro das Lamentaçöes" .

- Dia da limpeza

- Palestras para os alunos do período noturno

Tema: Meio Ambiente e Sustentabilidade - Prof. Antonio Vitor Rosa -

Tema Agricultura orgânica - Produtor orgânico: G

- Conversa sobre o andamento do projeto (17/11/1999)

Segundo a coordenadora da escola:

"- O comportamento dos alunos em relação a manutenção da limpeza durou pouco tempo."

Na ocasião a professora levantou a questão do limite de capacidade de atuação dos professores na reversão de posturas dos alunos. Um desafio é aproveitar o entusiasmo inicial para induzir mudanças de comportamento. 


\section{PARTICIPAÇÃO DAS EQUIPES EM EVENTOS DE TERCEIROS}

As equipes de educadores foram estimuladas, pelo coordenador, a apresentarem seus projetos em diversos eventos promovidos por outras instituições. Tal procedimento visava: fortalecer as propostas; incentivar e valorizar o trabalho das equipes; apresentar para a comunidade as iniciativas das escolas; divulgar as idéias e propostas assumidas pelos projetos (integração ao meio ambiente, agricultura orgânica, valorização das árvores, cidadania, qualidade de vida, etc.); prestigiar iniciativas de parceiros e articular encaminhamentos futuros

\section{- MOSTRA ECOLÓGICA - ESCOLA PROF. ROQUE BASTOS}

Neste evento organizado pela direção e por todos os professores da Escola 1, cada sala concentrava um tema , por exemplo: animais em extinção, reciclagem, economia de energia, etc. Os 4 professores cursistas da escola prepararam uma sala sobre agricultura, apresentando uma comparação entre agricultura convencional e alternativa.

No evento alunos monitores aplicaram um questionário, preparado pelo coordenador pedagógico da escola, sobre a sala de agricultura e seus assuntos principais.

Uma das professoras também foi responsável por outra sala que apresentava a Carta do Cacique Seatle, este trabalho foi desenvolvido com a alunos de uma das turmas envolvidas no projeto Horta Orgânica.. A participação e envolvimento de alguns alunos monitores era grande principalmente na sala do cacique Seatle.

Durante a mostra foi possivel conhecer outros trabalhos desenvolvidos na escola envolvendo educação ambiental, um interessante e que tratava de temas relacionando agricultura e meio ambiente era o Jomalzinho desenvolvido sob responsabilidade da professora de português no qual grupos de alunos preparam um jornal-mural com editorial, manchetes, informes, ilustrações, etc.

\section{- EXPAI - EXPOSIÇÃO AGRO-INDUSTRIAL DE IBIUNA}

As escolas participaram deste evento como parte de uma parceria com a Secretaria Municipal de Agricultura. Esta participação foi acertada como forma de valorizar e estimular a visitação dos estudantes no evento e também para divulgar e valorizar os projetos desenvolvidos nas escolas. Assim as equipes das 3 escolas de lbiúna ocuparam 2 estandes e apresentaram painéis sobre seus projetos. Diversos alunos da Escola 2, a pedido de alguns professores, apresentaram-se como voluntários para a montagem e plantão nos estandes. Posteriormente estes estudantes receberam certificados, a intenção foi reconhecer a iniciativa e compromete-los com o projeto.

Os estandes receberam uma grande visitação, todos os projetos chamaram atenção, algumas pessoas se interessaram mais pelas informações sobre o Parque Jurupará, apresentadas pela Escola 2, outros sobre a Agricultura Orgânica e outros ainda se interessaram pela Árvore da Esperança e pelo Muro das Lamentações e Alegrias da Escola 3. Infelizmente o livro de assinaturas só foi disponibilizado nos três últimos dias e não houve um livro para registro de impressões.

Um fato a ser destacado no evento foi a atuação dos professores da Escola 1 juntamente com outras pessoas e entidades no sentido de inserir na programação uma palestra sobre agricultura orgânica, a qual foi uma das mais concorridas no evento, inclusive devido a presença de estudantes da Escola 2 que realizavam pesquisas solicitadas por alguns professores. A equipe E2 destacou a presença e interesse demonstrado por um grande produtor rural da região quanto a agricultura orgânica, o qual chegou a visitar posteriormente a escola em busca de publicações sobre o assunto. Várias vezes foram observados estudantes avaliando e comparando o Muro das Lamentaçöes e Alegrias da Escola 3 com aspectos de sua escola. 
168

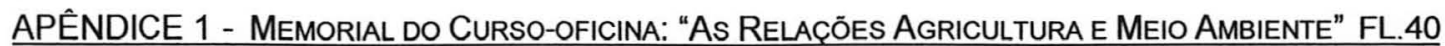

- EXPOGEO (18/10/1999)

Organizado pela Diretoria de Ensino de São Roque e região este evento de 4 dias reuniu todas as escolas estaduais de lbiúna, cada qual encarregada de apresentar trabalhos sobre diferentes "aspectos geográficos" da cidade tais como: população, relevo, economia, etc.

Numa estratégia de articulação da demanda oficial com o projeto "Valorizando as Árvores... " os professores da Escola 2 assumiram o tema "vegetação" e apresentaram dois trabalhos: o "Mapeamento da Arborização Urbana em Ibiúna" e a "Exposição sobre o Parque Jurupará". Alunos da escola mantiveram um plantão de monitoria junto aos painéis, apesar de alguns se mostraram interessados, a maioria não demonstrava envolvimento com os trabalhos expostos.

Considerações

Eventos do tipo: "mostra", "exposição" ou "feiras" tendem a assumir um caráter muito pontual, eventualmente para alguns estudantes que montaram ou apresentaram trabalhos pode haver ganhos educacionais, porém creio que 0 esforço dos organizadores e dos expositores (professores e alunos) poderia ser melhor aproveitado. Como conseguir isto? Esta resposta eu não tenho, mas è inaceitável que o trabalhos de semanas e até meses sejam destinados ao lixo no dia seguinte, no mínimo poderiam ser expostos em outros locais (exemplos: bibliotecas, outras escolas e outros espaços), outra opção mais sofisticada seria articular e aperfeiçoar estes trabalhos no contexto de um programa temático. A idéia de envolver diversas escolas em um evento de apresentação de estudos e trabalhos sobre a cidade é uma proposta que me parece promissora, principalmente em municipios de porte pequeno. Talvez fosse interessante integrar outras atividades como palestras e debates sobre temas locais; exposição de artesanato; festival de artes e outras.

\section{- ENCONTRO ESTADUAL EDUCAÇÃO, ENSINO E TRABALHO}

Este evento de 2 dias, organizado pelo Departamento de Geografia - USP e outras entidades incluiu palestras, mesas redondas e oficinas de apresentação e discussão de trabalhos educacionais oriundos de várias partes do estado de São Parreira. O coordenador estimulou a participação das equipes neste evento visando:

- divulgar e valorizar a iniciativa dos cursistas;

- valorizar e fortalecer os projetos;

- possibilitar aos cursistas conhecerem outros projetos e eventualmente formarem parâmetros comparativos para seus projetos;

- ampliar os horizontes de atuação dos cursistas.

Membros das equipes E1 e E2 participaram do encontro apresentando seus trabalhos durante as oficinas.. $\mathrm{O}$ coordenador crê que os objetivos foram atingidos: as sinteses dos trabalhos foram publicadas no Caderno de Resumos do evento, as equipes efetuaram contatos com entidades que desenvolvem trabalhos na região de lbiúna, os membros das equipes participaram dos debates nas oficinas sendo que um deles atuou como relator. Posteriormente um dos mediadores da oficina na qual as equipes E1 e E2 se apresentaram destacou, em conversa informal com o coordenador, a grande dedicação e envolvimento das equipes nos projetos 
APÊNDICE 1 - Memorial do CURSO-Oficina: "As RelaçŌEs Agricultura e MEIo Ambiente" FL.41

\section{RELATÓRIO DE CONCLUSÃO, ENVIADO À SECRETARIA ESTADUAL DE EDUCAÇÃO}

\section{APLICABILIDADE E VALIDADE}

A proposta de curso se mostrou com alto grau de aplicabilidade e validade seja pela temática, pelo público, pela metodologia ou pelo formato. Os objetivos iniciais que incluiam motivar o processo educativo, ampliar os conhecimentos sócio-ambientais e incentivar a atuação dos envolvidos foram alcançados satisfatoriamente.

Confirmou-se a suposição inicialmente de que a temática da agricultura e a perspectiva ambiental são muito relevantes para o público em questão. Por sua vez confirmou-se a grande carência de informações e experiência dos participantes quanto as relações entre agricultura e meio ambiente. Aproximadamente dois terços dos alunos dos professores cursistas estão diretamente ligados à agricultura. $\mathrm{O}$ tratamento do tema agricultura para este público e em especial o Projeto de Horta-orgânica desenvolvido pelos cursistas possibilitou aos seus alunos uma série de ganhos como: aumento da auto estima, redução da agressividade, maior interesse e participação nas aulas.

A metodologia considerando os princípios de educação ambiental permitiu aflorar questionamentos e discussões com relação ao meio ambiente urbano, ao uso e conservação das águas, ao turismo, à violência, aos valores sociais atuais, ao papel da escola e a outros assuntos.

Outro aspecto metodológico que se verificou aplicável e válido foi a adoção de diferentes procedimentos durante os encontros: aulas expositivas, palestras com especialistas, vídeos, exposições dos cursistas, debates, dinâmicas de grupo, oficinas temáticas, visitas à propriedades rurais e à unidades de conservação, avaliações periódicas e outros. Um destaque deve ser dado às atividades de campo que possibilitaram um contato direto $\mathrm{e}$ vivencial com os assuntos abordados através da observação e da coleta de depoimentos.

A possibilidade dos professores cursistas escolherem um assunto, definirem uma proposta, desenvolverem um projeto educacional e avaliá-lo foi outro ponto de grande valor formativo que possibilitou o crescimento profissional e pessoal dos participantes.

O formato de um curso de longo prazo com encontros periódicos (aproximadamente quinzenais) intercalados por periodos reservados para leituras, pesquisas, produção de relatórios, reuniões e outras atividades permitiu imprimir uma velocidade que não sobrecarregava demasiadamente os cursistas, mas que possibilitava a reflexão e avaliação constante das questões abordadas e das experiências vividas. Por sua vez este formato aliado à metodologia geral incentivaram e subsidiaram os cursistas em suas reconstruções conceituais sobre o tema central, sobre as questões ambientais e mesmo sobre o ensino em geral.

Os encontros regulares e os procedimentos adotados também permitiram um ganho quanto ao entrosamento dos professores cursistas nas unidades escolares e mesmo entre as três unidades do municipio de lbiúna participantes.

O envolvimento dos participantes com as questões ambientais foi grande, principalmente por remeter à realidade local e a aspectos cotidianos. É possivel identificar, através de alguns indicadores, a mudança de valores e comportamentos na grande maioria dos participantes. Diversos participantes declaram a intenção de dar continuidade aos projetos iniciados durante o curso ou desenvolverem novos projetos envolvendo questões ambientais. 
170

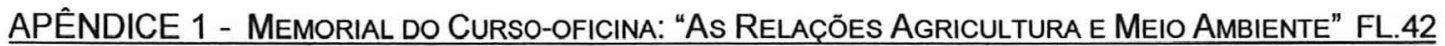

\section{REFORMULAÇÕES}

As inscrições devem ser por "equipes de professores" das unidades escolares, preferencialmente que tenham algumas turmas de alunos coincidentes.

\section{SUGESTÕES}

Reproduzir este curso em outras escolas e cidades com perfil de público envolvido com a agricultura.

Reproduzir o procedimento de execução de uma palestra informativa sobre o curso anterior ao período de inscrição no curso.

Desenvolver outros cursos relacionados à agricultura.

Desenvolver outros cursos relacionados ao meio ambiente e à educação ambiental.

Desenvolver outros cursos que permitam aos participantes o exercício de construção e aplicação de projetos educacionais.

Avaliar a possibilidade de incluir na grade escolar dos alunos e professores tempo para desenvolvimento de projetos.

Estimular a inclusão dos coordenadores pedagógicos nas equipes de professores que participem de cursos com esta proposta.

Destinar verbas para remuneração ou ajuda de custo para especialistas convidados desenvolverem palestras ou oficinas.

\section{OUTROS ASPECTOS POSITIVOS E NEGATIVOS}

Em cursos com propostas semelhantes a este (implicando no desenvolvimento de projetos na unidade escolar) um aspecto decisivo, capaz de definir o sucesso ou fracasso da iniciativa, relaciona-se a necessidade de apoio das direções das escolas envolvidas. No transcorrer deste curso foi possivel verificar diferentes posturas das direções, desde amplo apoio e envolvimento até o desprezo e desqualificação da iniciativa indicando inclusive uma falta de sintonia com as atuais reformulações que sofre o ensino no país. 
APÊNDICE 3 QUADRO RESUMO DE ATIVDADES DO CURSO-OFICINA “AGRICULTURA E MEIO AMBIENTE"

ETAPA 1 - AGRICULTURA E MEIO AMBIENTE (Módulo 1)

\begin{tabular}{|c|c|c|}
\hline $\begin{array}{l}\text { PALESTRA DE } \\
\text { APRESENTAÇÄO } \\
\text { E DIVULGAÇÄO }\end{array}$ & $\begin{array}{l}\text { PALESTRA: AGRICULTURA E MEIO AMBIENTE: A REVOLUÇĀO VERDE } \\
\text { APRESENTAÇÃO DA PROPOSTA CURSO } \\
\text { ENCAMINHAMENTOS }\end{array}$ & COORDENADOR DO CURSO \\
\hline ENCONTRO 1 & $\begin{array}{l}\text { RESPONDENDO COM ARTE: } \\
\text { O QUE ME FAZ UM PROF. PREOCUPADO C/ AS QUESTŌES AMBIENTAIS? } \\
\text { VIDEO: O FUTURO ROUBADO (TRECHOS) } \\
\text { PRODUZINDO NOSSO DIAGNÓSTICO SOBRE AGRICULTURA } \\
\end{array}$ & COORDENADOR \\
\hline ENCONTRO 2 & $\begin{array}{l}\text { AVALIAÇÃO DO ENCONTRO ANTERIOR } \\
\text { AULA EXPOSITIVA: IMPACTOS SÓCIO-AMBIENTAIS DA AGRICULTURA } \\
\text { RELATOS DE PESQUISAS E ENTREVISTAS }\end{array}$ & $\begin{array}{l}\text { COORDENADOR } \\
\text { COORDENADOR E CURSISTAS } \\
\text { CURSISTAS }\end{array}$ \\
\hline ENCONTRO 3 & $\begin{array}{l}\text { RÁPIDA PREPARAÇÃO P/ SAIDA A CAMPO } \\
\text { VISITA AO PRODUTOR ORGÃNICO "G" } \\
\text { MINI-PALESTRA SOBRE AGRICULTURA SUSTENTÁVEL } \\
\text { ALMOÇO COLETIVO } \\
\text { VISTTA AO PRODUTOR ORGÃNICO "J" }\end{array}$ & $\begin{array}{c}\text { COORDENADOR } \\
\text { HORTICULTOR ORGÃNICO "G" } \\
\text { HORTICULTOR ORGÃNICO "J" EAGROONOMA 'M' }\end{array}$ \\
\hline ENCONTRO 4 & $\begin{array}{l}\text { UMA PERSPECTIVA HOLISTICA DE MUNDO E } \\
\text { SUAS RELAÇÕES COM EDUCAÇÃO E AGRICULTURA }\end{array}$ & EDUCADORA "O" \\
\hline ENCONTRO 5 & $\begin{array}{l}\text { AULA EXPOSITIVA: AGRICULTURA SUSTENTÁVEL } \\
\text { AVALIAÇŌES E CONSIDERAÇŌES SOBRE } \\
\text { AS VISITAS AOS PRODUTORES ORGÃNICOS }\end{array}$ & $\begin{array}{c}\text { COORDENADOR } \\
\text { COORDENADOR E CURSISTAS }\end{array}$ \\
\hline
\end{tabular}

ETAPA 2 - EDUCAÇÃO AMBIENTAL (Módulo 2)

\begin{tabular}{|c|c|c|}
\hline ENCONTRO 6 & $\begin{array}{l}\text { AVALIAÇĀO GERAL DO CURSO - DINÃMICA DO BARQUINHO } \\
\text { PONTOS POSITIVOS E NEGATIVOS E EXPECTATIVAS } \\
\text { DEBATENDO EDUCAÇĀO AMBIENTAL }\end{array}$ & COORDENADOR E CURSISTAS \\
\hline ENCONTRO 7 & $\begin{array}{l}\text { APRESENTANDO-SE E DIZENDO O QUE MAIS GOSTA. } \\
\text { AQUECIMENTO CORPORAL } \\
\text { EXERCITANDO A CRIATIVIDADE } \\
\text { ATIVIDADE EXTERNA: OBSERVAÇÃO DO ENTORNO } \\
\text { REPRESENTANDO EM GRUPO AS OBSERVAÇŌES } \\
\text { CONSIDERAÇŌES SOBRE EDUCAÇÃO AMBIENTAL }\end{array}$ & EDUCADORA AMBIENTAL "A" \\
\hline ENCONTRO 8 & $\begin{array}{l}\text { APRESENTANDO CARACTERISTICAS PESSOAIS } \\
\text { CONSIDERAÇŌES SOBRE EDUCAÇÃO AMBIENTAL } \\
\text { DINÃMICA DE GRUPO: "DESATANDO NÓS" } \\
\text { SONHOS P/ A ESCOLA (INDIVIDUAIS E COLETIVOS) } \\
\text { AVALIANDO OS OBSTÁCULOS PI OS SONHOS } \\
\text { CONSIDERANDO OUTRAS EXPERIĖNCIAS } \\
\text { DEFININDO NOSSOS PROJETOS COLETIVOS } \\
\end{array}$ & EDUCADOR AMBIENTAL "M" E CURSISTAS \\
\hline ENCONTRO 9 & $\begin{array}{l}\text { DINÃMICA DE GRUPO: BRINCADEIRA NO PÁTIO } \\
\text { AVALIANDO O ENCONTRO } 7 \\
\text { AVALIANDO O ENCONTRO } 8 \\
\text { RELATANDO E DEBATENDO LEITURAS SOBRE E.A. } \\
\text { EXPLANAÇĀO SOBRE AGENDA } 21 \\
\text { RELATO DE ATIVIDADES PROMOVIDAS COM ALUNOS } \\
\text { ENCAMINHAMENTOS }\end{array}$ & $\begin{array}{c}\text { COORDENADOR E CURSISTAS } \\
\text { COORDENADOR E CURSISTAS } \\
\text { COORDENADOR E CURSISTAS } \\
\text { COORDENADOR E CURSISTAS } \\
\text { COORDENADOR } \\
\text { PROF }{ }^{\mathrm{a}} \text { HORTÊNCIA } \\
\text { COORDENADOR E CURSISTAS }\end{array}$ \\
\hline
\end{tabular}

ETAPA 3 - PLANEJANDO E PROMOVENDO PROJETOS EDUCACIONAIS (Módulos 3 e 4)

\begin{tabular}{|c|c|c|}
\hline NCONTRO 10 & $\begin{array}{l}\text { PALESTRA-OFICINA: VISŌES DE MUNDO: CONVENCIONAL X HOLISTICA } \\
\text { VALORIZANDO A EXPERIMENTAÇĀO (VIVÊNCIA) } \\
\text { (PERIODO VESPERTINO) OFICINA SOBRE PROJETOS }\end{array}$ & COORDENADOR EA.T.P. APARECIDA \\
\hline ENCONTRO 11 & $\begin{array}{l}\text { OFICINA EXTERNA: "VISITANDO A MATA ATLÃNTICA" } \\
\text { EXPLANAÇŌES SOBRE BOTÂNICA E SOBRE A MATA ATLÂNTICA } \\
\text { EXERCICIO DE DIAGNÓSTICO FLORESTAL }\end{array}$ & $\begin{array}{c}\text { BIÓLOGO "G" } \\
\text { BIÓLOGO "G" } \\
\text { COORDENADOR E BIÓLOGO "G" }\end{array}$ \\
\hline ENC & PALESTRA-OFICINA: HORTA ORGÃNICA, TEORIA E PRÁTICA & HORTICULTOR ORGÃNICO "G" \\
\hline ENCO & DE MUDAS DE ÁRV & A "P" \\
\hline ENCON & NTAL E EDUCAÇÃo & $\begin{array}{l}\text { AS } \\
\text { A "O" }\end{array}$ \\
\hline $\begin{array}{l}\text { ENCONTRO } 15 \\
\text { EVENTO: } \\
\text { EDUCAÇÃO E } \\
\text { DESENVLLVM. } \\
\text { SUSTENTÁVEL } \\
\text { EM IBIÚNA }\end{array}$ & $\begin{array}{l}\text { ABERTURA - PRONUNCIAMENTOS DE AUTORIDADES } \\
\text { PALESTRA: A COMERCIALIZAÇÃO DA AGRICULTURA ORGÃNICA } \\
\text { APRESENTAÇĀO E AVALIAÇĀOO DOS PROJETOS EDUCACIONAIS } \\
\text { MINI-PALESTRA: UMA INICLATIVA DE TURISMO RURAL EM IBIÜNA } \\
\text { MINI-PALESTRA: RECURSOS HIDRICOS E COMITES DE BACIA - } \\
\text { MINI-PALESTRA: RECUPERAÇĀO AMBIENTAL } \\
\text { DEBATE: DESENVOLVIMENTO SUSTENTÁVEL EM IBIUUNA }\end{array}$ & $\begin{array}{l}\text { SR. PREFETO EAUTORIDADES MUNICIPAIS } \\
\text { SOCIÓLOGO "L" } \\
\text { EDUCADORESEESTUDANTESPARTICPANTES } \\
\text { JORNALISTA "I" } \\
\text { EDUCADORA "J" } \\
\text { EDUCADORA "O" } \\
\text { TODOS OS PRESENTES }\end{array}$ \\
\hline
\end{tabular}

IMPORTANTE: Na etapa 3 além dos encontros, foram realizadas diversas reuniōes por escola para idealização dos pré-projetos; formulação dos projetos base; preparação de atividades dos projetos; preparação para participação em eventos; avaliações e encaminhamentos. 
ATENÇÃO PROFESSORES DE TODAS AS ÁREAS DO ENSINO MÉDIO

\section{PALESTRA E \\ CURSO-OFICINA DE ATUALIZAÇÃO AS RELAÇÕES ENTRE \\ MEIO AMBIENTE E AGRICULTURA ATRAVÉS DA EDUCAÇÃO AMBIENTAL}

O TEMA DAS RELAÇŌES ENTRE MEIO AMBIENTE E AGRICULTURA ASSIM COMO TODAS AS QUESTÕES AMBIENTAIS, PODE E DEVE SER TRATADO PELAS MAIS DIVERSAS DISCIPLINAS, DESDE GEOGRAFIA E BIOLOGIA ATÉ PORTUGUÊS E QUÍMICA PASSANDO POR MATEMÁTICA, HISTÓRIA, FILOSOFIA, ETC. PARA APRESENTAR MAIS INFORMAÇÕES SOBRE O TEMA E DISCUTIR SUA APLICAÇÃO EM SALA DE AULA SERÁ PROMOVDO UM CURSO-OFICINA DE ATUALIZAÇÃO PARA PROFESSORES DE ENSINO MÉDIO ( $2^{\circ}$ GRAU) DE SÃO ROQUE E REGIÃO.

VISANDO FAZER UMA EXPLANAÇÃO SOBRE O TEMA E DAR ESCLARECIMENTOS SOBRE O CURSOOFICINA SERÁ FEITA UMA PALESTRA DIA 20 DE FEVEREIRO A PARTIR DAS 8:30 HS EM SÃO ROQUE.

PARA INSCRIÇÕES E INFORMAÇÕES TELEFONAR PARA:

- SRTA. APARECIDA - A.T.P. DE CIÊNCIAS da D.E. FONE: 425-3667 Ramal 213

\section{ALGUMAS INFORMAÇÕES SOBRE O CURSO-OFICINA.}

A SER DESENVOLVIDO ENTRE FEVEREIRO E SETEMBRO DE 1999, O PROGRAMA DE $120 \mathrm{HS}$. É COMPOSTO POR CERCA DE 15 ENCONTROS, GERALMENTE DE 4 HORAS AOS SÁBADOS (EVENTUALMENTE OCORRERÃO ATIVIDADES QUE EXIGIRÃO MAIS HORAS) MAIS ATIVIDADES EXTRA-CLASSE (LEITURAS, PESQUISAS, REUNIÕES, PROJETO, ETC.).

A PROPOSTA ESTÁ DIVIDA EM QUATRO MÓDULOS:

- MÓDULO 1: AGRICULTURA E MEIO AMBIENTE: HISTÓRICO, STIUAÇÃO, PROBLEMASE PERSPECTIVAS

- MÓDULO 2: REFLETINDO SOBRE EDUCAÇÃO AMBIENTAL

- MÓDULO 3: SUBSIDIOS E MONTAGEM DE PROJETOS DE ABORDAGEM DO TEMA NAS ESCOLAS.

- MÓDULO 4: APLICANDO E AVALIANDO PROJETOS EDUCACIONAIS SOBRE O TEMA.

OS MÓDULOS 3 E 4 TERÃO CARÁTER DE OFICINA COM O OBJETIVO DE PREPARAR, DISCUTIR, APLICAR E AVALIAR PROJETOS EDUCACIONAIS, PREFERENCIALMENTE MULTIDISCIPLINARES. DESTA FORMA A PREFERÊNCIA PARA A PARTICIPAÇÃO NO CURSO SERÁ DADA A GRUPOS DE PROFESSORES DE UMA MESMA ESCOLA.

O CURSO-OFICINA CONTA COM O APOIO DO LABORATÓRIO DE EDUCAÇÃO AMBIENTAL DO DEPARTAMENTO DE CIENNCIAS FLORESTAIS- USP. OS PARTICIPANTES COM PRESENÇA E RENDIMENTO SATISFATÓRIOS RECEBERÃO CERTIFICADO DA ESALQ-USP - ESCOLA SUPERIOR DE AGRICULTURA LUIZ DE QUEIROZ DA USP, RECONHECIDO PELA SECRETARIA DE EDUCAÇÃO. 
APENDICE 5 - O QUE ME FAZ UM(A) PROFESOR(A) PREOCUPADO(A) COMAS QUESTŌES AMBIENTAIS? FL. 1

Refletindo e expressando-se através da arte - Atividade do $1^{\circ}$ Encontro do Curso-Oficina.

\section{OBSERVACÕES E CONSIDERACQÕES}

Conforme pode ser observado nas páginas seguintes, as instruções e em especial a questão apresentada, permitiu 2 tipos de abordagem: histórica e temática. Ambas foram ricas e contemplaram os objetivos iniciais. Seis participantes destacaram questões relacionadas à agricultura e outros 4 citaram alimentação e agricultura. A grande incidência de considerações sobre agricultura e sobre alimentos, muito provavelmente, foi um decorrência da palestra de divulgação realizada na semana anterior. Apenas 4 participantes fizeram referências à educação, um citou o fato de ser professor mas não atribuiu nenhuma particularidade a isto, apenas 3 explicitaram uma preocupação didático-pedagógica diante das questões ambientais (sendo 2 delas divergentes).

Alguns aspectos merecem destaque:

a) A pequena incidência de reflexões na perspectiva educacional ou sobre a situação do educador durante as apresentaçōes individuais.

b) As reflexões da profa Safira, pela sua profundidade e adequação ao enfoque educacional.

c) A grande diversidade de representações sobre meio ambiente.

d) A emergência de duas posições:

Posição: "nada é em vão, sempre fica alguma coisa" e

Posição: "Como mudar: nota Dez na escola e Zero na vida ?"

\section{ESCLARECIMENTOS SOBRE A ATIVIDADE}

Objetivos: a) estimular os cursistas a exporem suas preocupações educacionais relacionadas às questões ambientais, considerando suas funções de educadores;

b) permitir a troca de informações e experiências;

c) resgatar e valorizar os conhecimentos dos cursistas;.

d) aumentar o conhecimento interpessoal entre os participantes;

e) possibilitar aos cursistas a percepção de idiossincrasias e de convergências entre os membros da turma, a fim de estimular a tolerância interpessoal, incentivar a aproximação entre os cursistas, contribuir para o fortalecimento de uma identidade coletiva e para a construção de futuras equipes de trabalho.

Materiais: Recursos para desenho e colagem: folhas de papel com uma face em branco (cartazes velhos), estojos de giz de cera e de lápis coloridos, revistas velhas, tesouras e colas.

Procedimentos - Após disponibilizar os materiais, o Coordenador passou a seguinte instrução: Através de técnicas artisticas (desenho e colagem) responder individualmente a questão:

\section{"- O que me faz um(a) professor(a) preocupado com a questão ambiental?"}

- Decorridos 20 minutos foi organizada uma rápida exposição dos trabalhos produzidos.

- Na seqüência cada cursista apresentou seu trabalho explicando seu significado.'

- Após todas as apresentações, o coordenador estimulou os cursistas a tecerem considerações sobre a atividade e seu tema, resultando em aproximadamente 30 minutos de explanações.

Produtos a) Cartazes artisticos;

b) Fotos e transcrição das explicações sobre os cartazes

c) Debate promovido na seqüência (transcrição no Apêndice 6) 
174

APENDICE 5 - O QUE ME FAZ UM(A) PROFESOR(A) PREOCUPADO(A) COM AS QUESTÖES AMBIENTAIS? FL. 2

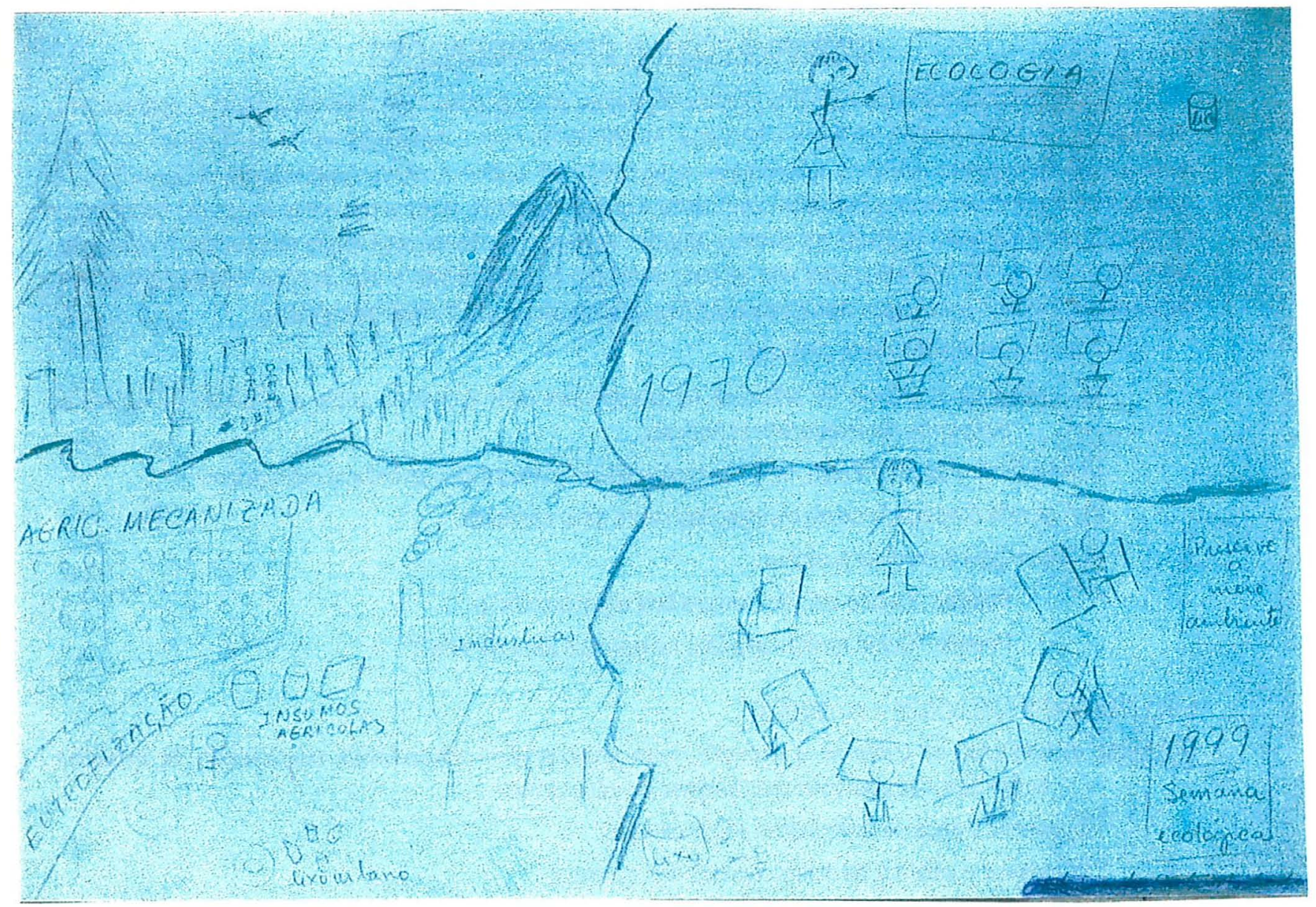

Inicialmente me retratei em 1970 lecionando ecologia com os alunos sentados enfileirados.

Nesta época a natureza ainda tinha matas ciliares, mas já tinha fornos de carvão,

já tinha também a população urbana com seu lixo. Eu venho falando desde 1970,

estamos agora em 1999 eu mudei a dinâmica (cartazes, atividades como semana ecológica, ...),

mas este assunto e este método de educação não vem surtindo resultados. (...)

$\mathrm{Na}$ agricultura com insumos químicos, mecanização, eutrofização dos rios, aumento do lixo urbano, industrialização. Mostrando que o trabalho do professor não está refletindo.

Isto é uma vida de uma professora que não deu em nada!

Profa. Safira 


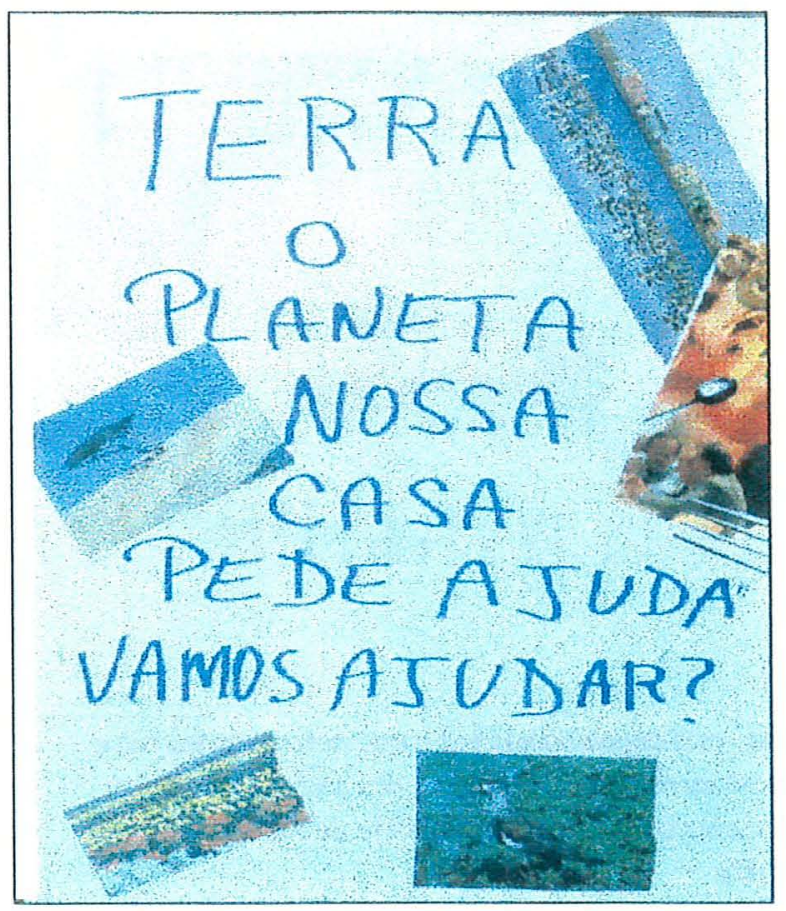

Coloquei esta frase: até quando? Até quando irá acontecer a destruição do meio ambiente, principalmente feita pelo o homem, pois os demais animais conservam o ambiente. O homem é praticamente inútil para a natureza. $O$ homem, o ser humano está aos poucos, destruindo tudo o que tem. Coloquei a questão da migração: as pessoas sem condições de viverem no ambiente em que estão (plantar ou morar) $e$ isto vai agravando mais o problema no mundo todo.

Prof. ${ }^{\text {FFlorípedes }}$
Eu havia pensado na frase:

"Terra: o planeta pede ajuda, vamos ajudar?".

É interessante, pois eu fiquei por último e parece que a frase fecha as reflexões. Posso parecer um pouco pretensiosa em querer ajudar o planeta todo, mas acho que podemos pensar de uma forma global e agirmos localmente, como já vem sendo passado para nós, o tempo todo.

Coloquei algumas coisas do planeta e uma pessoa comendo uma pera, para destacar

a preocupação com a alimentação.

Trata-se de uma proposta: tentar ajudar um pouco.

$$
\text { Prof }{ }^{a} \text {. Flora }
$$

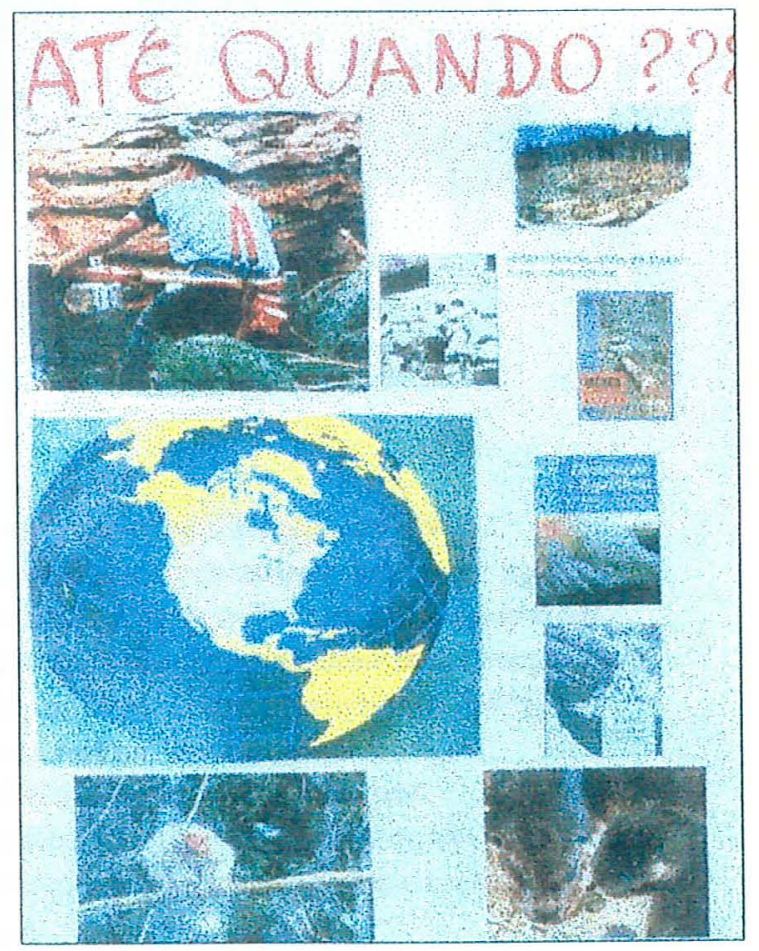




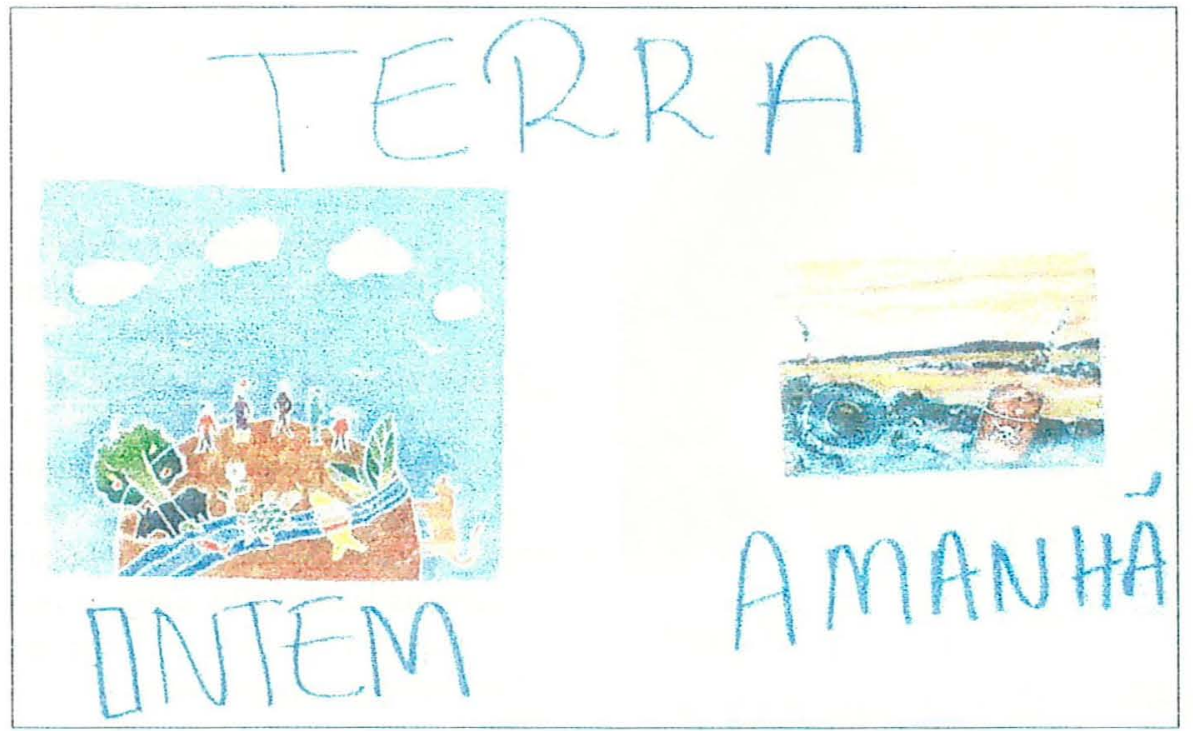

Quando eu nasci eu via o planeta bonito, lindo, maravilhoso, mas depois vamos nos conscientizando que não é bem assim, que existem muitos problemas. Percebo que se eu não fizer algo hoje e nós professores de um modo geral, nós seres humanos acabaremos tendo o planeta como um grande depósito de lixo e sem vida. Prof ${ }^{a}$.Amélia

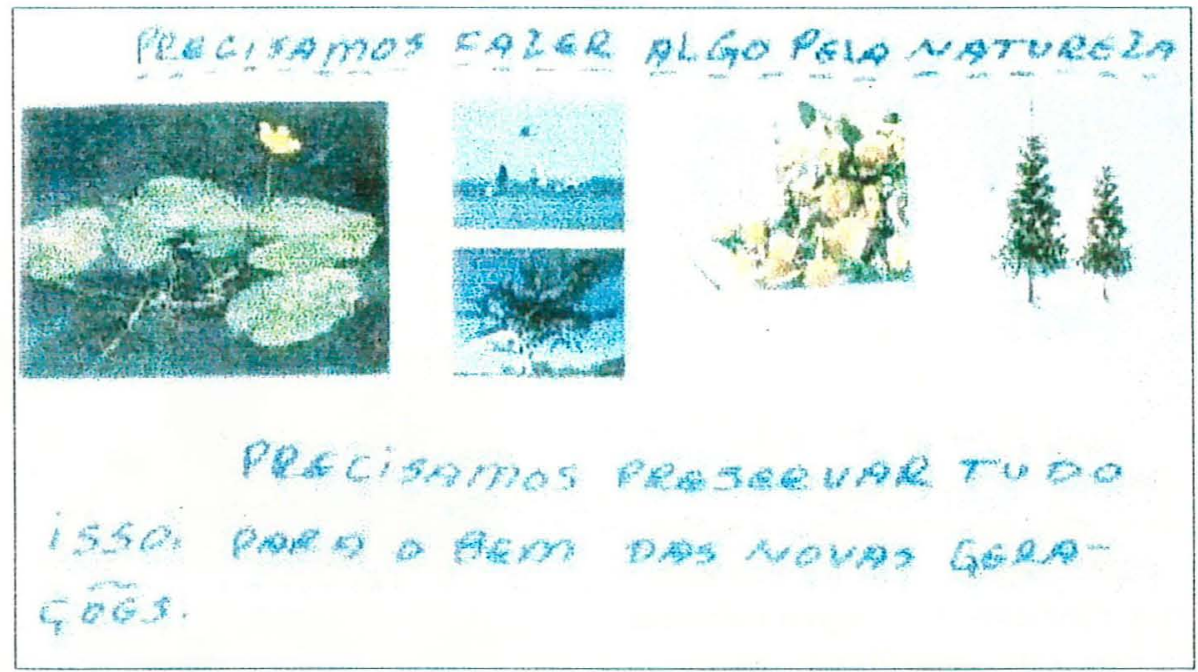

Minha preocupação é com as gerações futuras, acho que o homem já poluiu o máximo. Agora precisamos pensar em deixar para nossos filhos e netos uma natureza mais preservada. Uma preocupação com a natureza, com a água, com as plantos e com os animais, com o ar menos poluído, que chegue a nossa mesa alimentos mais saudáveis. Coloquei uma arvore de natal importada como um alerta, no sentido que para os nossos netos ou bisnetos a natureza não seja apenas algo artificial, no papel.

Algumas vezes falamos: "eu sozinho não posso mudar", está errado, podemos sim, imaginemos se cada um de nós fizermos nossa parte já é algo importante.

Além disso nós professores somos responsáveis por passarmos para os alunos, é impossível que falamos, falamos, falamos e damos exemplos e estas palauras não façam com que eles procurem mudar alguma coisa. 


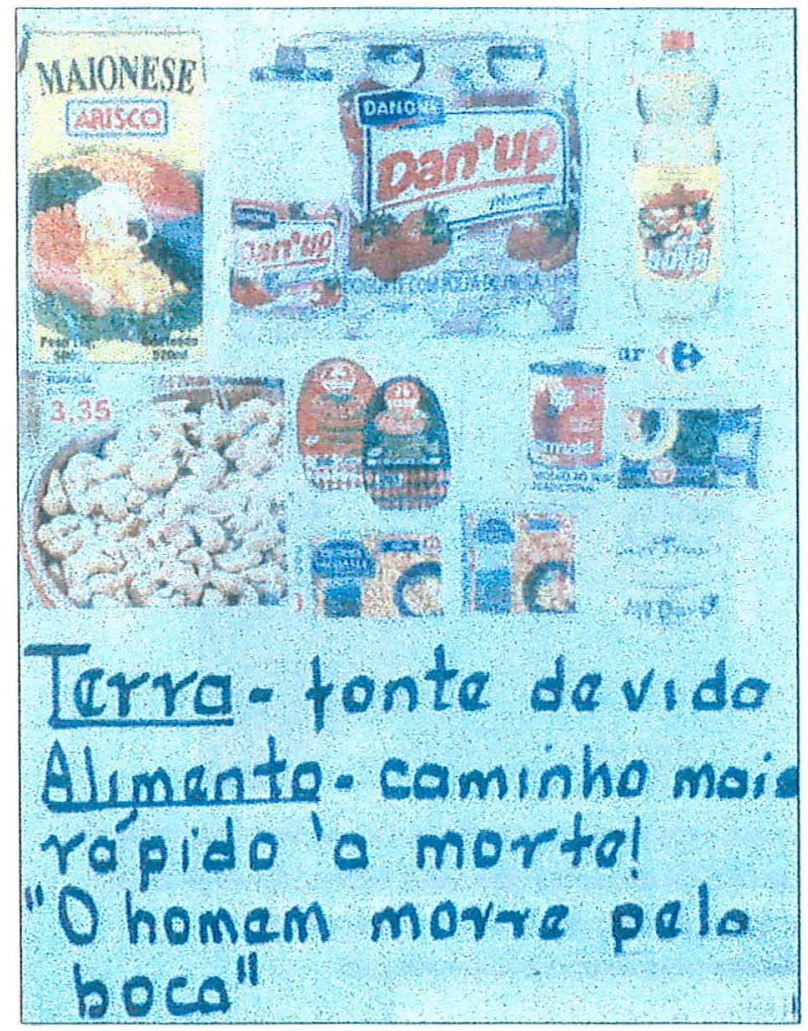

A terra é fonte de alimentos e o alimento é fonte de vida, sustenta a vida.

Mas o que percebemos hoje é que o alimento tornou-se o caminho mais rápido para a morte. Ao invés de transmitir a vida, ele transmite a morte, por causa do uso de agrotóxicos e outros aspectos da agricultura moderna. Prof. ${ }^{a}$ Iara

Eu vivi uma época diferente.

Meu pai era agricultor e ele não usava agrotóxicos, quer dizer usava muito pouco. $A$ base de nossa alimentação era quase toda lá do sítio, isto na minha infância.

Depois foi entrando os agrotóxicos. Meu pai guardava as sementes de um ano para outro depois fomos percebendo que o milho já não dava tínhamos que comprar as sementes.

Eu coloquei que temos nos dar as mãos, para vermos se conseguimos mudar esta situação. Prof ${ }^{a}$. Esmeralda

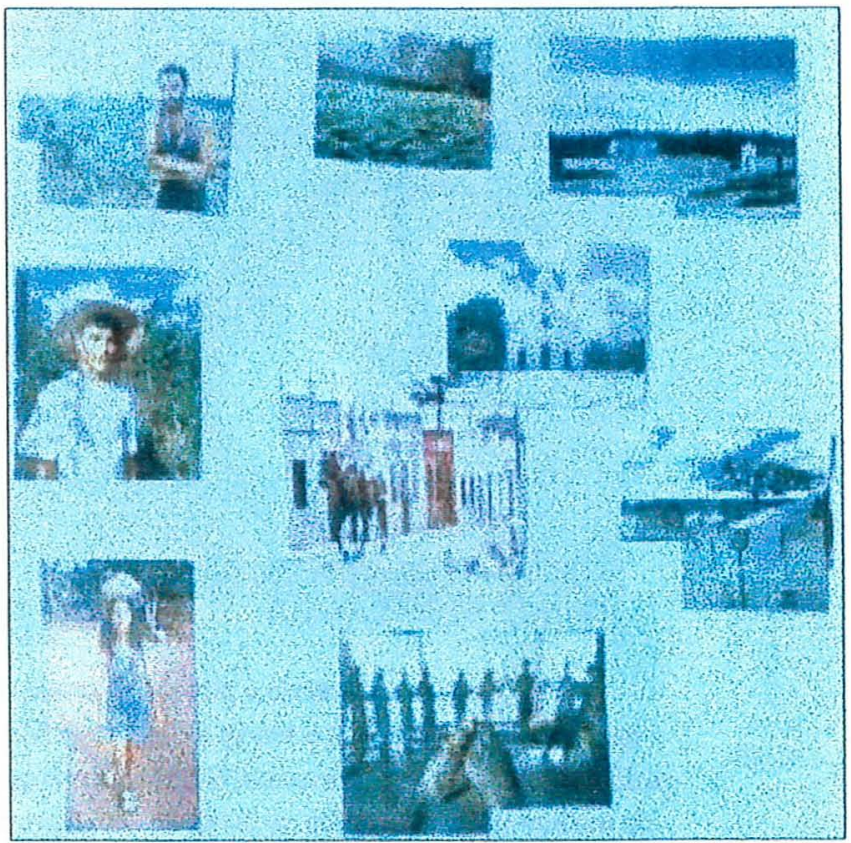




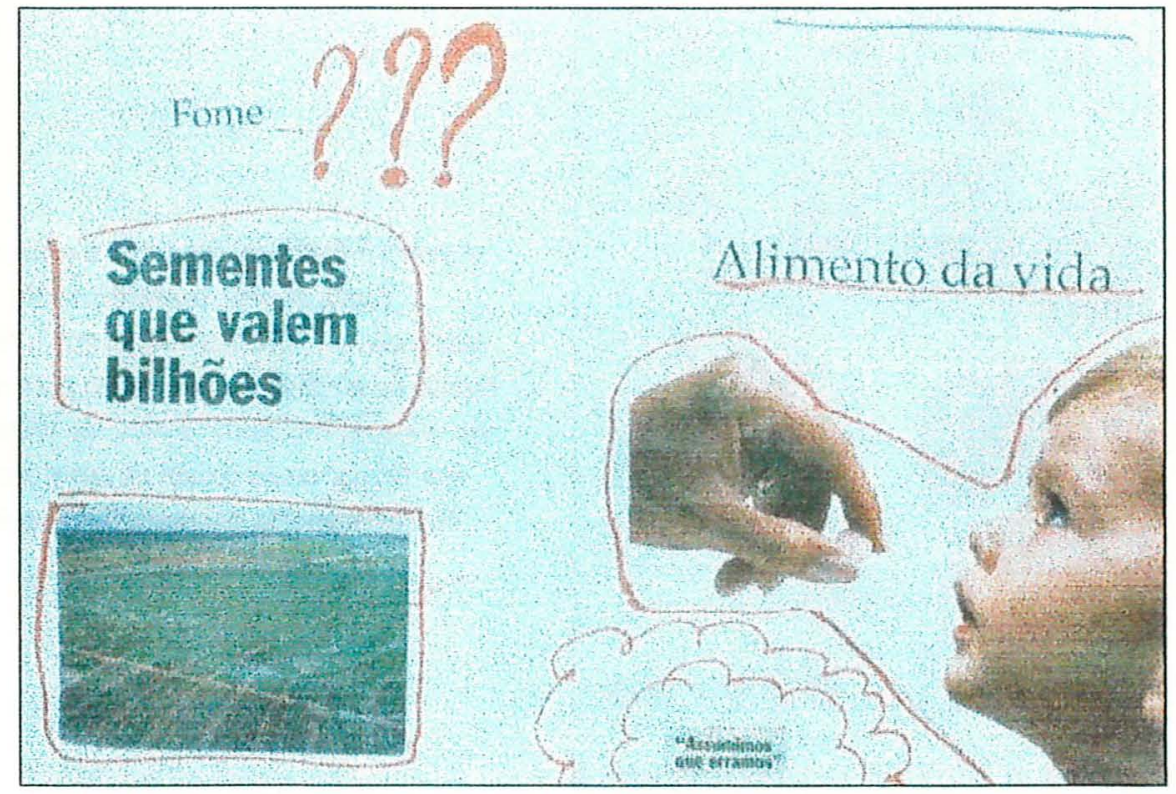

O que me preocupa muito hoje é a questão da fome. Vemos pessoas passando fome. Depois veio uma reflexão:

Que tipo de alimentos damos para nossos filhos? Que tipo de alimentos deixamos nossos alunos produzir?

Eu comparo estes alimento a drogas. Por isso é preciso assumirmos que erramos!. Com uma preocupação em tentar mudar, mas está muito complicado.

$$
\text { Prnfa Rosn }
$$

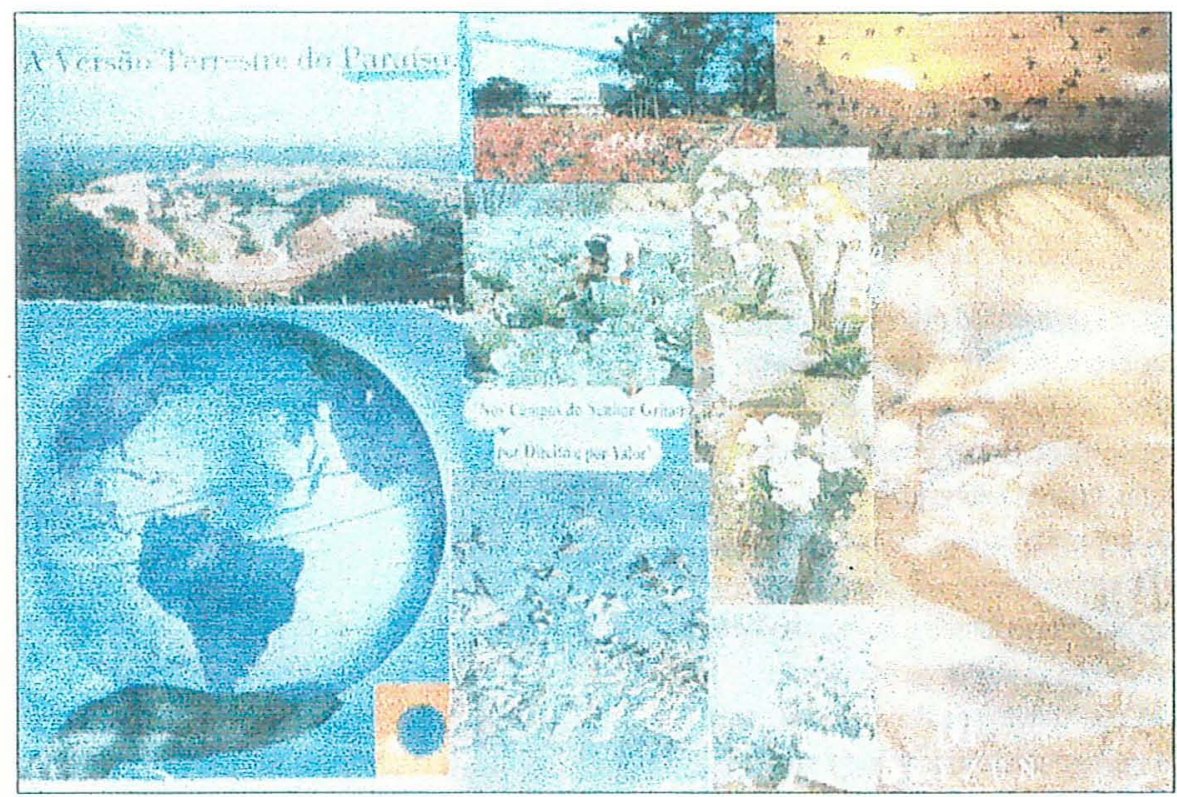

O homem segurando o planeta na palma da mão, com uma leveza tão grande, que transmite tanta paz e tranqüilidade, mas não é isto que temos visto. Eu gostaria que nós pudéssemos contribuir para esta melhoria, para que nossos filhos possam sorrir e levar uma vida de melhor qualidade, todos os seres de modo geral. Que aqui possa ser uma versão do paraíso. 


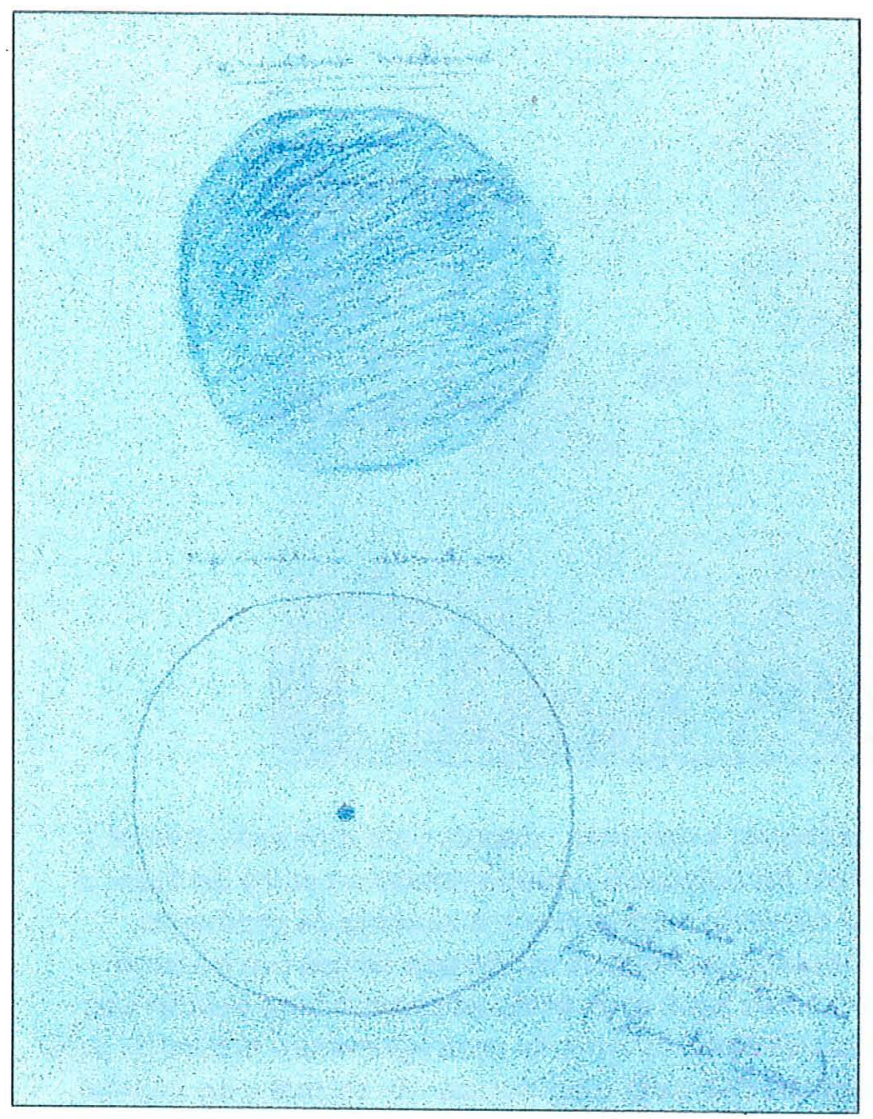

(inicio da fala não registrado)

Iniciar a agricultura alternativa -orgânicaseria a solução para a sobrevivência humana aqui na terra.

Prof. Lobo
Eu fiz uma coisa bem simples que diz: devemos tentar a conscientização de que se agredirmos a natureza muitos animais serão extintos $e$ isto provoca um desequilíbrio ecológico. Prof ${ }^{a}$. Ema
Uan cumbicenti deque: se aguedinmos a vatureza muitos - lopécies de anvimois - Rntanjós em extumposo
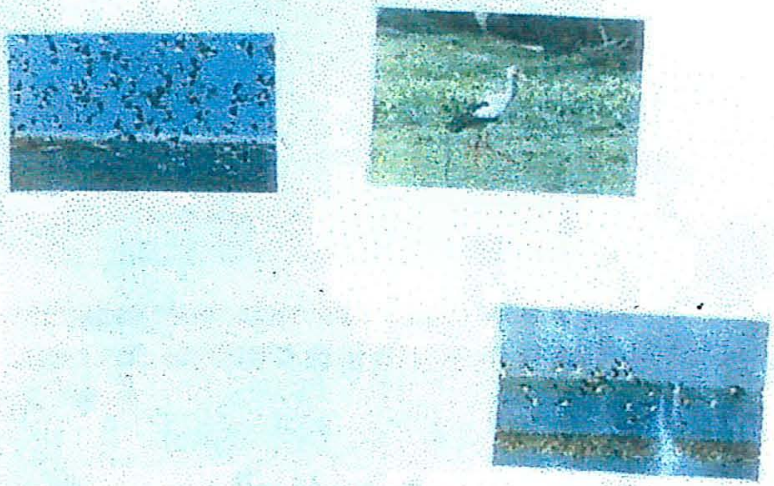
180

APÊNDICE 5-O QUEMEFAZUM(A) PROFESOR(A) PREOCUPADO(A) COMASQUESTÖES AMBIENTANS? / FL.8

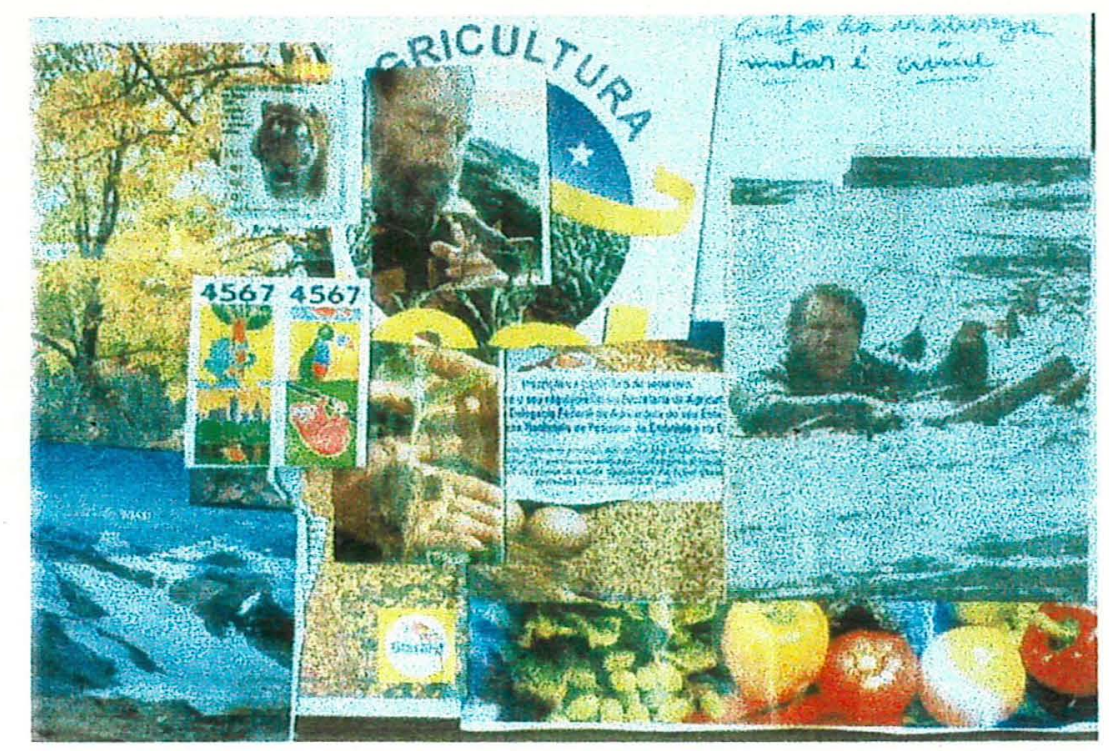

Eu fiz uma espécie de ciclo da natureza. Eu coloquei a natureza, depois vem o mundo animal e neste mundo animal figura o homem. O homem foi colocado representando o centro de tudo: 0 centro natural e o centro animal . Coloquei também a agricultura, o sistema de produção.

Temos um homem no centro consciente. Depois nos tempos modemos temos um homem representando a decadência, o sufoco que os seres humanos estão passando hoje devido aos agrotóxicos e outros produtos químicos que consumimos através de uma agricultura praticada pelo homem de uma forma até criminosa. Mas o homem depende da natureza -do animal e do vegetal, tanto quanto o vegetal $e o$ animal depende do homem. Mesmo porque se analisamos o ciclo natural da terra, o homem hoje pertence ao reino animal, amanhã ele pode ser do reino vegetal e assim sucessivamente. Cabè ao homem como ser pensante, mudar todo este sistema, é só querer

\section{Profa Rosalina}

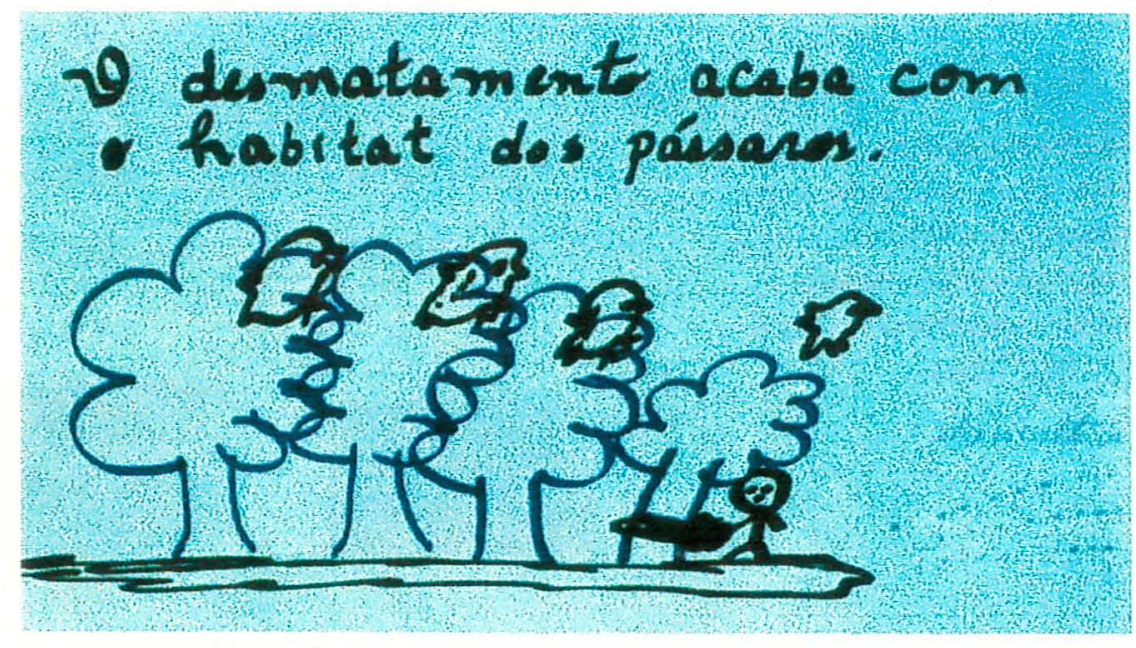

Eu pensei que o desmatamento indiscriminado para implantação da agricultura está fazendo com que reduza o habitat dos pássaros e das aves, provocando a extinção destes. Prof. Jasmim 


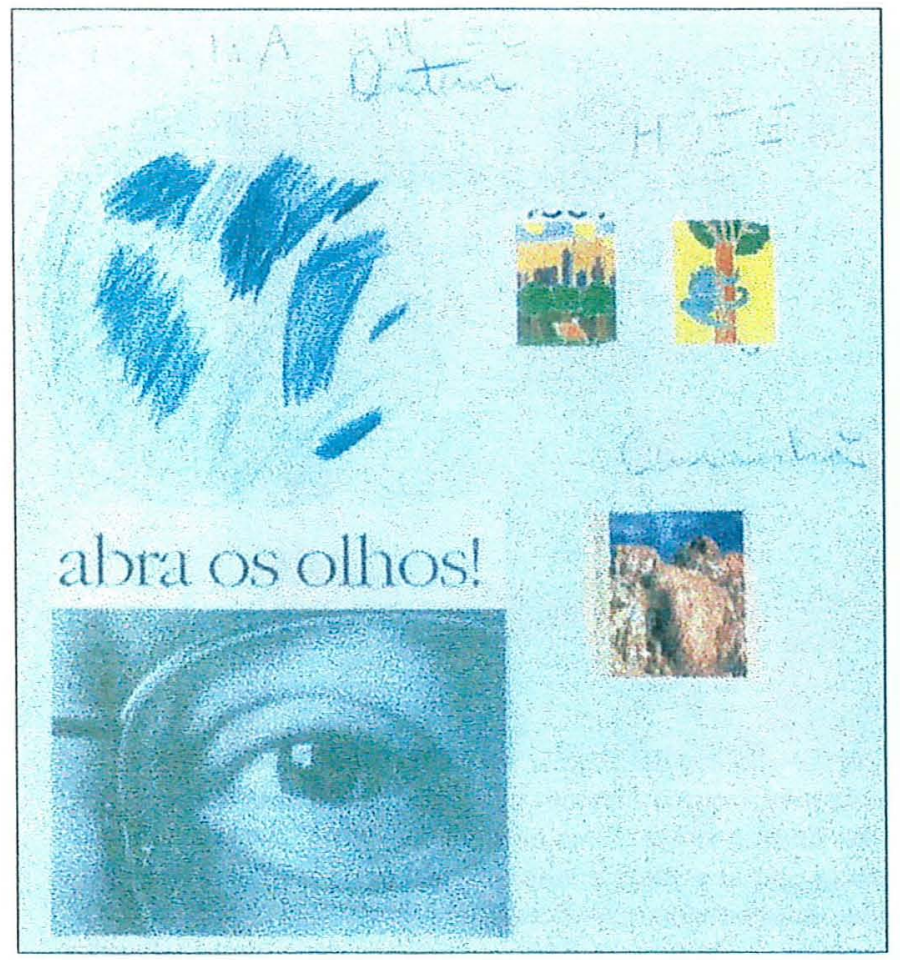

Aqui esta uma reflexão, sobre o que estamos fazendo, sobre o que foi e está sendo feito na Terra, ontem e hoje.

Antes eu via a Terra com azul de céu, de oceanos de águas límpidas e muito verde, verde natural e não cheio de agrotóxicos. Isto hoje está um tanto mudado, os bichos tentando sobreviver, mudando hábitos. Tentar abrir os olhos para que não chegue a destruição total. Prnfa Vinlotn

O planeta Terra está chorando, tem algumas lágrimas de sangue. Tem um anjo da morte rondando, ameaçando a terra.

Acima tem um anjinho para ver se toca a alma dos seres humanos, o espirito da natureza consiga tocar as pessoas para proteger mais. $O$ anjinho precisa ajudar-nos a fazer alguma coisa. Mas o anjinho estámeio .... Prof ${ }^{a}$.Jade

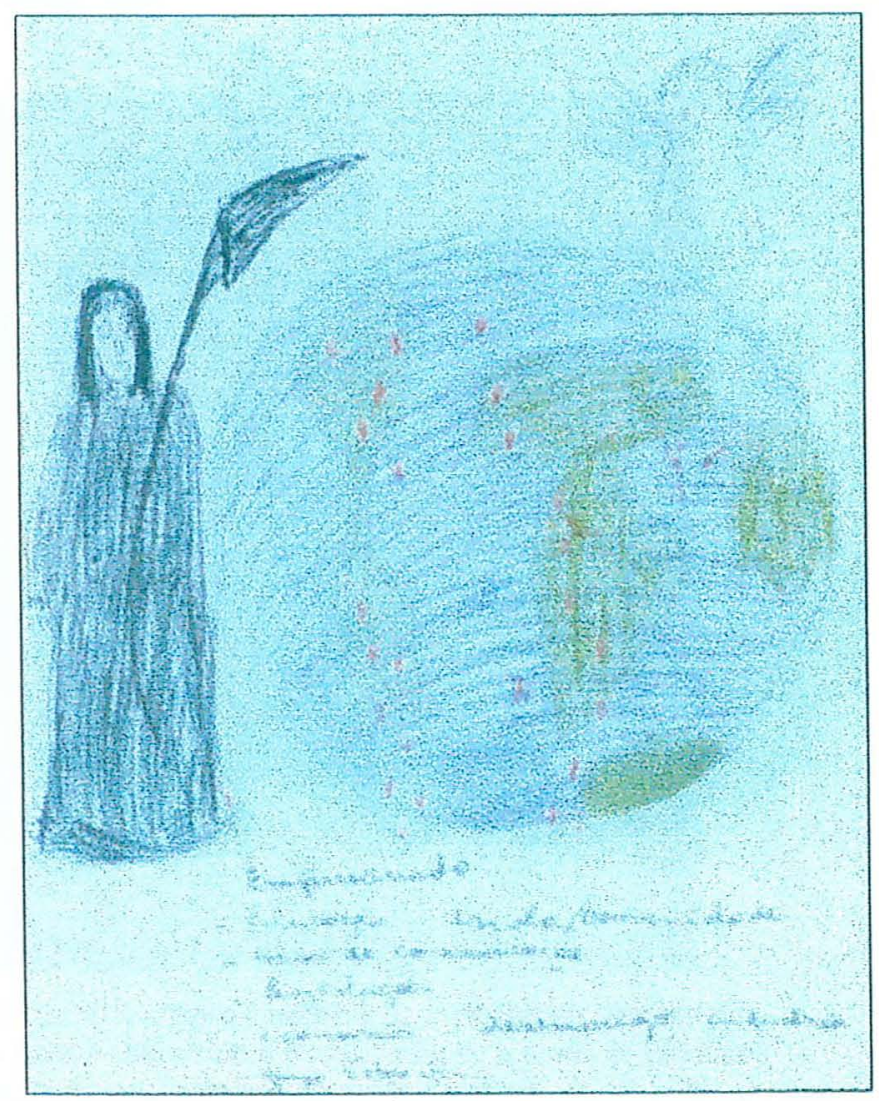




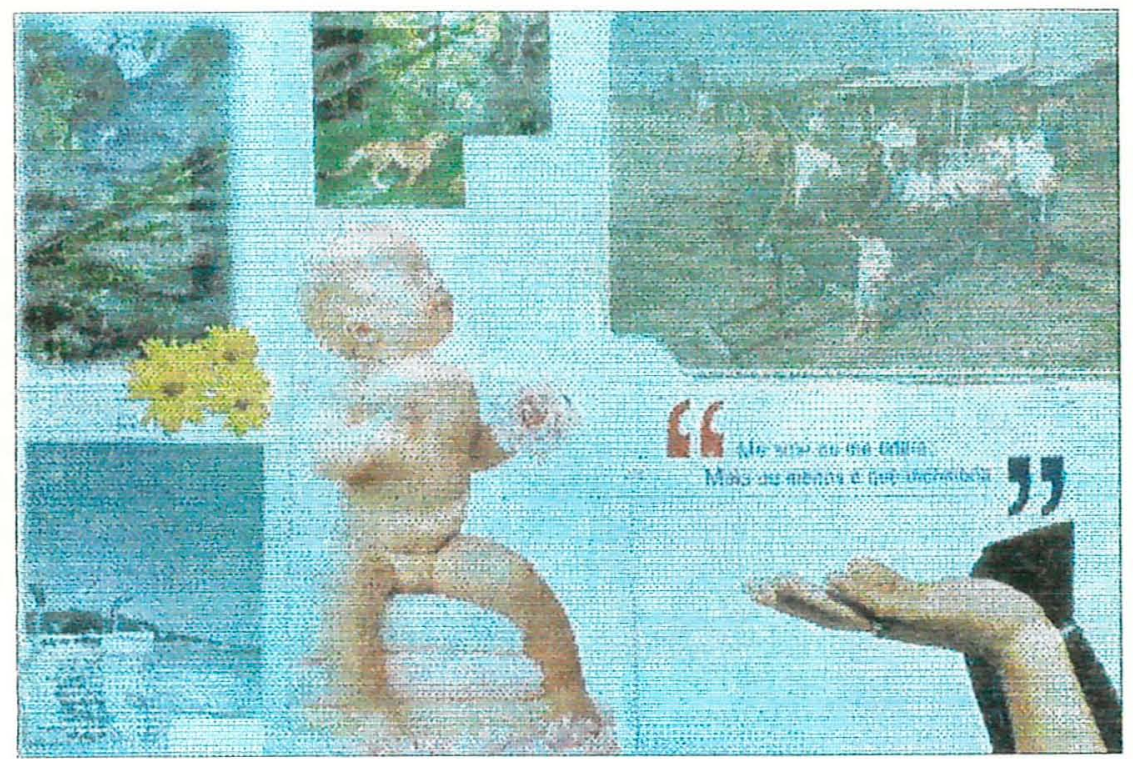

A primeira coisa que me faz preocupado é pensarmos que o Homem não está tendo uma convivência pacífica, serena, com o meio ambiente. Considerando a frase: " me ame ou me odeie" eu me incluo na parte do me ame, no sentido de estar procurando adquirir mais conhecimento para tentar passar para estes "que odeiam": os industriais, os grandes produtores que vão destruindo a terra sem se dar conta que aquilo tem vida, vida humana, vida animal ... As populações, as famílias mais marginalizadas necessitam do meio ambiente. $O$ meio ambiente além de fornecer alimento e trabalho, também fornece lazer e diversão. Minha preocupação é esta: que o homem se integre ao meio ambiente. Prof. Carneiro

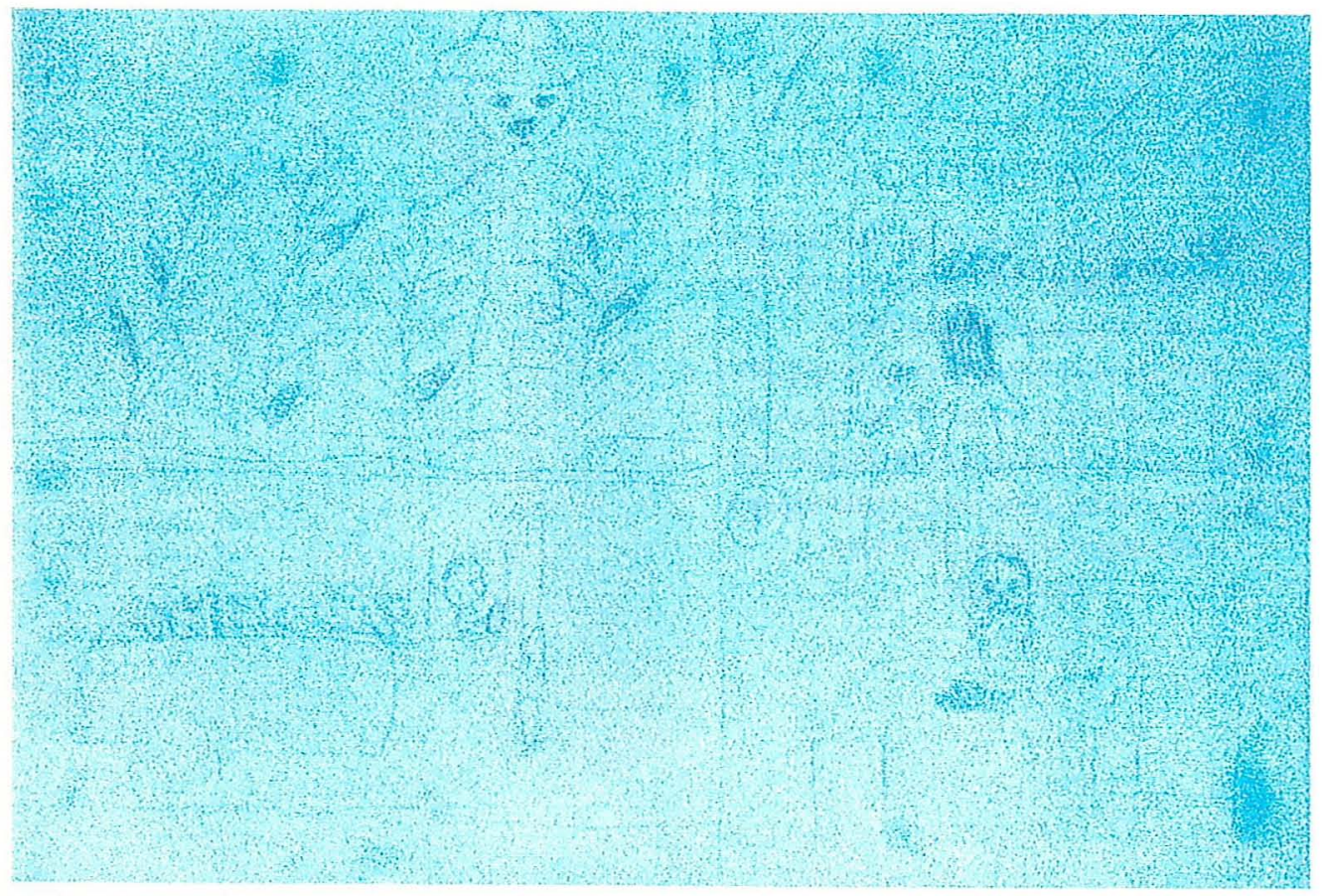

Fiz um tipo de quadrinhos. Primeiro o agricultor todo orgulho com sua plantação crescida. Depois o caminhão levando a produção para a quitanda. A mãe com o filho comprando e depois o filho comendo o milho (todo gostoso), cheio de agrotóxicos! Destaco a preocupação do alimento com agrotóxicos. 


\title{
EXPLANAÇÕES DOS CURSISTAS SOBRE SUAS POSIÇÕES E PREOCUPAÇÕES EDUCACIONAIS E AMBIENTAIS.
}

\author{
(TRANSCRIÇÃO DE FITA CASSETE (TRECHOS) / $1^{\circ}$ ENCONTRO / 20/03/1999)
}

\begin{abstract}
Comentários do pesquisador: Nas falas aparecem vários aspectos importantes para a pesquisa como: o grau de conhecimento dos educadores sobre o assunto; as preocupações e dificuldades educacionais enfrentadas; as diferenças de posturas e preocupações entre os cursistas; importância e influência da mídia e da cultura; dificuldades estruturais da escola pública; etc.
\end{abstract}

1. (Carneiro) ... A gente devia tá com base na agricultura para nós ensinarmos agricultura correto. Como já foi citado aqui, o agrotóxico, a gente tem que pensar que a agricultura antes de usar o agrotóxico ela tem que primeiro preparar a terra, ou seja, as árvores vão cair antes do veneno ser usado, e a população está aumentando de maneira tal que não só a gente deve alertar a população rural que o agrotóxico é ruim, mas também começar a conscientizá-los de que há formas de se fazer cultivo que pode conservar os nutrientes que a terra tem, porque não adianta só pensar no lado próximo, porque se ele ficar sem agrotóxico e começar a fazer tipos de plantações que leva até o esgotamento, a conseqüência também será fatal. Daí nós não vamos ter danos, não vamos ter o alimento com veneno para comer. Então acho que a gente tem que pensar no geral. Quando a gente tem que pensar no ambiental, a gente não pode pensar em determinado espaço; a gente tem que ver o espaço e o caminhar juntinho. E completando ai o que ela falou pensar no local, agir globalmente. Isto é uma idéia que eu já tenho a algum tempo, principalmente porque eu tenho uma faç̧ão política que tem um partido que pensa assim. Então a gente tá indo nesse patamar. Acho que isso é um ponto válido. A terra será mudada se a gente agir aqui. A gente fala mas como? A água que escorre das plantações vai para os rios, mares, 0 mundo todo, então é válido, isto ai agir localmente.

2. (Violeta.) - Depois que eu apresentei o meu trabalho, e todo mundo falou, eu achei que tem alguma coisa haver com o que todos nós estamos fazendo aqui. É uma frase do Renato Russo do Legião Urbana: "Disseste que se tua voz tivesse força igual a imensa dor que sentes. Teu grito acordaria não só a tua casa, mas a vizinhança inteira". Acredito que todos nós estamos aqui porque acreditamos nesta frase.

3. (Vitor) - ( ...) Eu queria centrar um pouco no foco das pessoas; como as pessoas se apresentaram? , o que vem trazendo este tipo de preocupação nas pessoas? , que tipo de angústia? A angústia dela é o questionamento mesmo, ela percebeu bem. Nós temos compartilhado um norte, um sul; uma direção?

4. (lara) - Eu penso assim, que nós estamos na mesma situação daquele beija-flor na floresta. A mata pegando fogo, a bicharada fugindo e o passarinho voltando com o biquinho cheio de água. E a bicharada: "-Você está louco, vai morrer lá". Ele falou: vou fazer a minha parte. Então se cada um de nós começar a fazer um pouquinho, uma coisa mínima que seja, isto vai fazer a diferença.

5. (Rosa) -Trabalho de formiguinha. Vamos encontrar pessoas que diz: vocês são loucos, isto não tem mais jeito. O homem não tem mais jeito; vocês estão perdendo tempo.

6. (Flora) - Eu acho assim, é interessante porque como a Safira comentou sobre as etapas que vem sendo trabalhada na ecologia. A gente percebe uma coisa. Eu coloquei bem isto aqui, diz que vamos ajudar este ponto de interrogação. Porque todas as vezes que eu tenho a oportunidade de comentar entre os meus alunos em sala de aula eu comento, e informação eles tem bastante. Só que a maneira, é...a dificuldade maior que a Safira é a mestra. Ela trabalha horta com alunos. Dá licença, deixa eu elogiar um pouco. Ela trabalha horta com os alunos, trabalha jardinagem. Ela sabe. Eu gostaria até de trabalhar isso ai com eles, mas o que eu percebo, que hoje em dia a preocupação deles é diferente, então outra coisa, você tem que manter o seu ambiente limpo. $O$ que é conceito de ambiente? O que é ambiente para eles? Então o ambiente nada mais é o que faz parte do que nos rodeia. Então se você tá na sala de aula, se você gosta do seu ambiente, você não vai ficar jogan- 


\section{APÊNDICE 6 - POSICÕES E PREOCUPACÕES EDUCACIONAIS E AMBIENTAIS DOS CURSISTAS FL. 2 de 4}

do lixo no seu ambiente, se não vai ficar destruindo seu ambiente, seu espaço pequeno. Então o que que a gente encontra: muita dificuldade , eu concordo com ela. Eu até gostaria de aprender alguma dinâmica, alguma coisa que fizesse que meus alunos parassem; eu gostaria de informar, mas formar cidadão capaz de estar meIhorando. Porque é muita pretensão da minha parte, querer chegar e falar assim: vou mudar a cabeça de todo mundo, isso aí não vai acontecer, e agir localmente, é agir com os que a gente tem, mas é dificil. Sabe assim, eu gostaria até, eu to fazendo esse curso, porque eu gosto de educação ambiental, acredito, ... mudei bastante; depois que veio, é...assim... assistindo, vendo vídeo, me preocupo mais. Mas infelizmente, cai naquilo que Safira falou. Você acaba, para, depois que fez um trabalho, senta e fala assim: o que foi que eu fiz, onde foi que eu falhei. Eu queria formar um cidadão capaz de ser crítico!

7. (Ceci) - É modificar comportamento do aluno...

8. (Safira) - Atingir os alunos ...

9. (Lobo) - Eles entendem até demais...

10. (Ceci) - Eles entendem mas não absorvem.

11. (Flora) - Não absorvem.

12. (Safira) - Eles respondem. Nota 10 na prova, mais na vida: zero.

13. (Ceci) - No cotidiano nada.

14. (Safira) - Então não tem aprendizado.

15. (Carneiro) - Na realidade, acho que está havendo ai um egoismo humano sabe, è imediatista. O pessoal não está pensando na geração que vem. Se preocupam no agora, eles pensam assim, eu vivo agora, o agora é que interessa. Daqui a 3 minutos não sei se vou estar vivo, o resto se vira com o que vier. Está faltando humanidade, solidariedade.

16. (Rosa ) - A questão do meio ambiente... acho que o capitalismo levou a isso. Poder é a lei do muito mais forte, e nessa questão da lei do mais forte, perdeu-se o respeito ao ser humano e a pessoas acham que a morte não existe.

17. (Flora ) - Mas numa classe que tem 40 alunos, você atingir pelo menos 3 , eu penso assim, 3 mudem o comportamento, esses 3 irão multiplicar a informação, só que para você atingir 3 dentro de uma classe é complicado.

18. (Carneiro) - Minha preocupação é que você atinge estes 3 e os outros que estão vendo o que está acontecendo, que nem a Safira falou: eles lutaram durante tanto tempo e ... ( falas simultâneas)

19. (Safira ) - Ai eu vejo, o grande fator é que a escola não é reconhecida. Escola é um elemento estranho na comunidade. Fala-se uma linguagem que não é a linguagem da vida.

20. (Flora) - É verdade.

(FIM DO LADO A - I NÍCIO DO LADO B DA FITA)

21. (Violeta) - Existe situações onde a própria escola exclui a vinda dos pais, certo. Ai depois ela quer esses pais, mas ela exclui. Conversando com as meninas que estão fazendo magistério, nós estávamos falando sobre recursos didáticos para o ensino de ciências. E um dos recursos era excursão. E que numa excursão nós poderiamos aproveitar os próprios pais para monitorar as crianças, para que eles pudessem dividir a responsabilidade conosco, e se falou que não dá certo; nẫo é possivel fazer isso.

22. (Safira) - Como mãe, quando eu tinha filhos pequenos, eu queria participar. Em parte para ajudar e em parte pela segurança. Mas a escola diz: 'a mãe tem que aprender a desmamar seu filho'.

23. (Violeta) - Exatamente. A escola exclui os pais e depois ela quer que os pais venham nas reuniões. Aí não aparece pais. Aqui tem 1500 alunos, eu acredito e numa reunião aparece 200, 180 pais.

24. (Aparecida) - Gostaria de falar: vocês não podem esquecer que a escola é formada principalmente por professores. A escola não é uma entidade em que os professores são professores e a escola é escola. Então acho que muito que vocês desejam que aconteça na escola está nas mãos de vocês mesmos. 
APÊNDICE 6 - POSIC̄ÕES E PREOCUPAC̄ÕES EDUCACIONAIS E AMBIENTAIS DOS CURSISTAS FL. 3 de 4

25. (Safira) - Mas a gente vem brigando, nós estamos brigando.

26. (Vitor) - Acho que a Cida tem razão, mas tem que manter também as proporções da questão do poder. Nós professores temos um grande poder na sala de aula, mas também enfrentamos o poder, que queria ou não existe o poder na escola também.

27. (Aparecida) - Mas é exatamente ai onde eu quero chegar: que o professor tem muito poder na escola, e vocês talvez não tenham percebido este poder. Com o contato que eu tenho com outras escolas eu vejo muitas vezes professores constrangidos dentro da escola. Eu acho que o professor tem que achar o seu lugar lá dentro. Porque o professor é a força da escola.

28. (Violeta) - Eu tenho tentado fazer isso com as meninas que estão saindo do magistério. Sabe, sentar, conversar e realmente animá-las, porque é possivel. É possivel mudar. Se não deu certo até agora, nós temos que procurar caminho pra mudar o que está errado.

29. (Carneiro) - Saindo um pouco da escola nesse negócio de poder, e voltando ao meio ambiente: Quem faz as normas? as regras para o meio ambiente funcionar, dita as normass, vai ser assim, assado, são os deputados e senadores. E os deputados e senadores são madeireiros, usineiros, ... Então como a gente vai querer mudar. A gente tem que agir localmente, mas esquece também que a parte da gente é cobrar estes que fazem as leis, que permitem que suas industrias sejam detetizadas de maneira errada, é ai que a gente também tem que alertar os alunos, tem que falar. Porque a nós se restringe o ensinamento. Ensinamento base na escola, quer queira ou não, é ditado pelas ordens que vem lá de cima. Então as Normas para ser mudada é cobrar e falar: se vai ter votação para uma lei para não desmatamento, deputados que tem madeireiras não deveriam votar, simplesmente isto.

30. (Rosa) - Eu tenho a impressão que o tempo pra gente resolver o problema de agrotóxico é muito curto, portanto não podemos esperar demais até que os alunos aprendam a votar

31. (Carneiro) - A gente sabe que tem fertilizante nos Estados Unidos, que já faz 20 anos que foi excluido. A lei brasileira, dos nossos deputados, permite trazer para cá o que eles deixaram estocados lá, porque não tem como vender. Vem tudo para cá e eles vão ganhando em cima disto dai.

32. (lara) - Vocês viram aquele bichinho que foi proibido de vender porque causa impacto ambiental? Aquele crustáceo, a Estrela está sendo multada.

33. (Vitor) - Tem um estudo interessante, eles chamam de poluição biológica que é você inserir um ser completamente diferente num ambiente causando bastante danos. Por exemplo: proliferação de pardais é uma grande poluição biológica.

34. (Jade) - Algo assim que influencia a nivel mundial, são os meios de comunicação, a mídia. Porque na hora de você votar, quem tem mais dinheiro para fazer mais propaganda, usar TV, fazer cartazes, na hora de fazer propaganda para o candidato, o meio de comunicação vai influenciar. Um deputado que não vai faz nada bom para o povo, vai conseguir ganhar. Isto é o marketing político. A televisão, também o jornalismo, a Globo, ... poderiamos lutar também para que tivéssemos uma TV pública. Tem gente que luta pelas rádios piratas, para as pessoas terem suas rádios comunitárias, para que todos tivessem acesso aos meios de comunicação. Tá tendo um pouco de acesso, mas de uma forma sensacionalista através do Ratinho, que faz para conseguir audiência, mas não está fazendo alguma coisa para engrandecer o povo. Ta fazendo um serviço mais sensacionalista. Não esta fazendo esta apresentação de serviços de orientação. A única que presta um pouco de serviço é a TV Cultura; então teria que ter acesso aos meios de comunicação.

35. (Rosalina) - Eu acho o seguinte, tudo é possível mudar; tudo que a gente faz não é em vão; sempre fica algo de bom. $\mathrm{O}$ importante é o seguinte, que eu acho que tudo depende do aluno. Nós devemos sempre persistir nisso dai. Orientar, mudar. Primeiramente mudar nossa mentalidade e através desta mudança ir orientando essas crianças que depende de nós. Agora, mesmo que tenha dificuldade no ambiente que nós estamos atuando, pode ser na escola, pode ser em casa, pode ser no meio social como um todo. Mas nós não devemos desistir. Sempre procurar orientando, porque desta nossa geração consciente hoje, que depende as crianças de 
hoje, do Brasil de agora. Então cabe a nós gradativamente fazer estas mudanças e não desanimar diante das dificuldades. Porque as dificuldades sempre existiram, o homem justamente está aqui para vencer estas dificuldades. Deixar uma herança positiva a esses que virão.

36. (Vitor faz comentários sobre os procedimentos da atividade e seus resultados).

37. (Safira) - Mas, outro dia você disse que diminui o número de alunos, porque não tem como conhecer. E é exatamente, nós temos 45 , até para fazer uma nota é impossivel. (Várias pessoas falando junto) ... esta é a briga que a gente reclama.

38. (Aparecida) - ... Eu também sou professora, tenho o mesmo problema que vocês, quando faço orientação técnica, faço para 45,50 .

39. (Safira) - O ideal é uma coisa, a realidade é outra.

40. (Ceci) - Permite um conhecimento melhor, mais aprofundado.

41. (Vitor) - A gente viu, que se deixássemos, se tivéssemos mais tempo, ficariamos conversando sobre o que rolou aqui bem mais tempo. Isso com 20,18. Com 45 realmente...?, talvez seja então:(...) Se a gente não vai desistir, como vamos enfrentar? A pergunta que colocada para nós é: como a gente vai conseguir fazer isso, infelizmente com $40,45 \ldots$ ?. Sem perder de vista que a gente quer que reduza.

42. (Safira) - $O$ adolescente vai dizer: Ah, o meu é igual ao dela. Quando é muita gente começa a usar essa técnica. Não vou nem falar, porque o meu é igual ao dela. É uma maneira dele sair pela tangente.

43. (Comentários sobre encaminhamento do dia).

44. (Jade) - Uma coisa que me angustia também, a gente trabalha bastante com adolescente, a gente vê que não tem emprego para eles. A questão ambiental também está relacionada com emprego, como é que a pessoa vai sobreviver, vai se adaptar num ambiente, se ele não tem emprego? Então, ao mesmo tempo que tem a briga das instituições, a gente mesmo quer trabalhar para educação ambiental, o equilibrio entre o progresso e o meio ambiente. Ao mesmo tempo tem o lado da indústria, do trabalho, qual é a alternativa destes jovens? Eu vejo que lá em São Roque os poucos jovens que trabalham lá, trabalham no mercado de São Roque. Esta é uma situação que está me angustiando bastante. Eles estão estudando e dizendo o que eles vão fazer?

45. (Ceci) - Um outro assunto relacionado a isso, na parte da alimentação, e a gente já passou. Tava falando sobre os aditivos químicos, as coisas que eles comem. Ai, na hora eu já invoquei: e os vegetais que nós comemos, está na mesma situação? É o nosso grande problema... É professora. Ai eles começaram a falar o que colocam, o que não colocam pra cenoura durar, pra isso, pra aquilo... E professora não tem jeito, se não for assim, a gente não sobrevive. Ai eu te digo, o que que eu falo pra esse aluno? A economia, eles vivem disso. Professora, não tem jeito, se não for assim. Eu falo: 'Mas você não está vendo, você está acabando com sua saúde quando coloca agrotóxico?' Eles falam: 'Professora, o tênis, a roupa que usa tem que jogar fora'. 'Você não se protege?' Eu passei tal defensivo, meus pelos todos cairam. Olha o grau gente! (...) na caixa de cenoura usam um produto para ela não melar, não apodrecer.

46. (Lobo) Há uns 3 anos atrás, teve aqui em Ibiúna, um curso sobre uso de agrotóxicos, veio um pessoal de fora, de outras cidades. Eles colocam, mesmo, que muita parte da intoxicação dos agricultores, é por falta de informação. Então tem trabalhar com os agricultores, então tem que falar, tem que informar realmente como tem que se fazer ...

47. (Ceci) - Eles têm consciência ..., eles sabem , ... eles sabem que não podem ...

48. (Safira) - Tem sim ... eles sabem responder ...

49. (Flora) - Tem que ter mudança de comportamento.

50. (Ceci) -É a mudança de comportamento que é dificil !

51. (Lobo) - Os pais fazem daquela forma ..

\section{Fim da transcrição .}


APÊNDICE 7 - RESGATANDO CONHECIMENTOS, DEBATENDO EDAGNOSTICANDO A STUUACÃO DA AGRICULTURA

Os participantes reunidos em 4 grupos de 4 ou 5 pessoas, discutiram e produziram os quadros abaixo considerando as informações e impressões decorrentes de:

a) Palestra proferida na semana anterior pelo geógrafo Antonio Vítor Rosa

b) Vídeo apresentado momentos antes, tratando sobre os danos à saúde provocados por agroquímicos e outros produtos industriais;

c) Formação profissional de cada um;

d) Experiências de vida, em especial aquela decorrente de residirem e lecionarem em uma região cuja economia se baseia em atividades rurais.

DIAGNÓSTICOS DOS CURSISTAS SOBRE SOBRE AGRICULTURA EM GERAL

Grupo 1

AGRICULTURA HOJE
CARACTERISTICAS MUNDIAIS
- PRODUÇÃO EM LARGA ESCALA
- USO DE GRANDE QUANTIDADE DE AGROTÓXICOS
- SEMENTES HÍBRIDAS
- NÃO PREOCUPAÇÃO COM QUALIDADE DE NUTRIENTES E SIM COM DIVIDENDOS
CAUSAS
- REVOLUÇÃO INDUSTRIAL
- CAPITALISMO
CONSEQÜÊNCIAS
- PERDA DA AGRICULTURA HEREDITÁRIA
- PROBLEMAS GENERALIZADOS PARA A SAÚDE E AMBIENTE COMO UM TODO
- DIMINUIÇÃO IMUNOLÓGICA DOS ORGANISMOS
- PERDA DA QUALIDADE (PALADAR E AROMA) DOS NUTRIENTES)

Grupo 2

O AVANÇO DA TECNOLOGIA, DECORRENTE DO AUMENTO DA POPULAÇÃO, GERANDO O AUMENTO DA PRODUTIVIDADE LEVA O HOMEM A RECORRER À INDUSTRIA QUÍMICA, PROVOCANDO DESASTRES SOCIAIS EJOU AMBIENTAIS.

Grupo 3

\section{CAPITALISMO}

- PREOCUPAÇÃO COM A QUANTIDADE E "QUALIDADE VISUAL";

- LUCRO DE UM GRUPO PEQUENO QUE DETÉM O CAPITAL;

- POLITICA ECONÔMICA DEFENSORA DOS PEQUENOS GRUPOS PRIVILEGIADOS;

- AGRICULTURA MECANIZADA (MONOCULTURA) QUE LEVA AO DESEQUILÍBRIO ECOLÓGICO;

- MUTAÇÃO DE ESPÉCIES LEVANDO A EXTINÇÃO.

TODOS ESSES FATORES EM CONJUNTO PROVOCAM ALTERAÇÕES NA QUALIDADE DO AR, DA ÁGUA E DO SOLO COLOCANDO EM RISCO A VIDA NA TERRA.

\section{Grupo 4}

1- GANÂNCIA

\section{AGRICULTURA:}

2- USO INDISCRIMINADO DE AGROTÓXICOS E ADUBOS SINTÉTICOS

3- HOMEM E MEIO AMBIENTE DOENTES

4- POSSIBILIDADE DE EXTINÇĀO

5- ANGÚSTIA, DESESPERO, DEPRESSÃO, IMPOTÊNCIA.

Observação: Ver no Apêndice 8 o texto coletivo produzido a partir destas fichas. 


\section{APÊNDICE 8 TEXTO COLETIVO: "DIAGNÓSTICO GERAL SOBRE A AGRICULTURA"}

\section{DIAGNÓSTICO GERAL SOBRE A AGRICULTURA}

(versão preliminar para avaliação)

Partindo dos cartazes dos grupos (apêndice 7) o Coordenador da Oficina redigiu o texto abaixo o qual tem o caráter de uma produção coletiva. Os trechos em LETRAS MAIÚSCULAS foram retirados das fichas e os textos sublinhados foram propostos pelo Coordenador para reflexão e futuras discussões. Todos devem ler e avaliar, anotando as correções que considerar necessárias.

\section{AGRICULTURA HOJE}

\section{CARACTERISTICAS gerais}

- PRODUÇÃO EM LARGA ESCALA associada à expansão do sistema de MONOCULTURAS.

- USO DE GRANDE QUANTIDADE DE AGROTÓXICOS.

- MECANIZAÇÃO .

- uso de SEMENTES HÍBRIDAS.

- constante busca por AUMENTO DA PRODUTIVIDADE.

- PREOCUPAÇÃO com a QUANTIDADE E com a "QUALIDADE VISUAL" (aparência) dos produtos agrícolas e desconsideração quanto a QUALIDADE DE NUTRIENTES dos alimentos produzidos;

- Desequilibrios e má distribuição dos produtos (opção por produtos exportáveis e de matérias primas para as agro-indústrias) e dos beneficios da atividade (fome e miséria para muitos e desperdícios e grandes lucros para alguns).

\section{CAUSAS}

- GANÂNCIA (PREOCUPAÇÃO COM ganhos econômicos).

- REVOLUÇÃO INDUSTRIAL e certo modelo de AVANÇO DA TECNOLOGIA.

- Crescimento da capacidade e do poder da INDÚSTRIA QUÍMICA e de máquinas.

- USO INDISCRIMINADO DE AGROTÓXICOS E ADUBOS SINTÉTICOS

- CAPITALISMO - sistema político-econômico que implica na defesa de grandes LUCROS para GRUPOS PEQUENOS e PRIVILEGIADOS de indivíduos e empresas.

- Desconsideração quanto às dinâmicas naturais (bio-geo-químicas) e sociais.

\section{CONSEQÜÊNCIAS}

- PERDA DE conhecimentos populares sobre AGRICULTURA.

- PERDA DA QUALIDADE (PALADAR, AROMA e NUTRIENTES) dos alimentos.

- DESEQUILÍBRIO ECOLÓGICO e POSSIBILIDADE DE EXTINÇÃO de muitas espécies animais e vegetais

- Degradação da QUALIDADE DO AR, DA ÁGUA E DO SOLO.

- Seres humanos E MEIO AMBIENTE DOENTES.

- Ocorrência de DESASTRES SOCIAIS E AMBIENTAIS que colocam em RISCO A VIDA NA

TERRA. Decorrentes de PROBLEMAS GENERALIZADOS PARA A SAÚDE E para o

AMBIENTE COMO UM TODO (entre eles a DIMINUIÇÃO IMUNOLÓGICA DOS ORGANISMOS e a redução da biodiversidade).

Por fim é preciso ressaltar que ao constatarmos este quadro, somos atingidos por sentimentos do tipo: ANGÚSTIA, DESESPERO, DEPRESSÃO, IMPOTÊNCIA ...

\section{COMENTÁRIOS DO PESQUISADOR:}

Devido à carência de tempo na programação esta versão do texto não foi discutida com o grupo, o que teria sido interessante para levantar alguns pontos questionáveis e eventualmente complementar outros. 


\section{RELATÓRIO - VISITA À AGRICULTURA ORGÂNICA}

No bairro da Cachoeira fizemos uma visita à propriedade do Sr. Geraldo, onde foi feito uma análise de como funciona a agricultura orgânica: técnicas, produção, estudo e avaliação do trabalho.

O proprietário optou por morar na zona rural onde cultivou a terra de maneira correta, estudando primeiramente o solo e seus nutrientes, em seguida desenvolveu uma produção diversificada caminhando junto com a natureza e não contra elà.

Durante a visita, o proprietário fez uma síntese de todo o seu trabalho e mostrou o processo de plantação, desde a montagem de mudas até a colheita.

Enfim, a visita nos ajudou a entender melhor todo o processo da agricultura orgânica, que é uma atividade que exige do trabalhador organização, responsabilidade e confiança naquilo que faz. É importante divulgar a sua experiência e assim multiplicar a quantidade de agricultores orgânicos. É uma mudança a longo prazo, porém com um resultado extraordinário. 
APÊNDICE 9 - EXEMPLOS DE RELATÓRIOS DE VISTAS AOS PRODUTORES ORGÂNICOS FL. 2 de 2

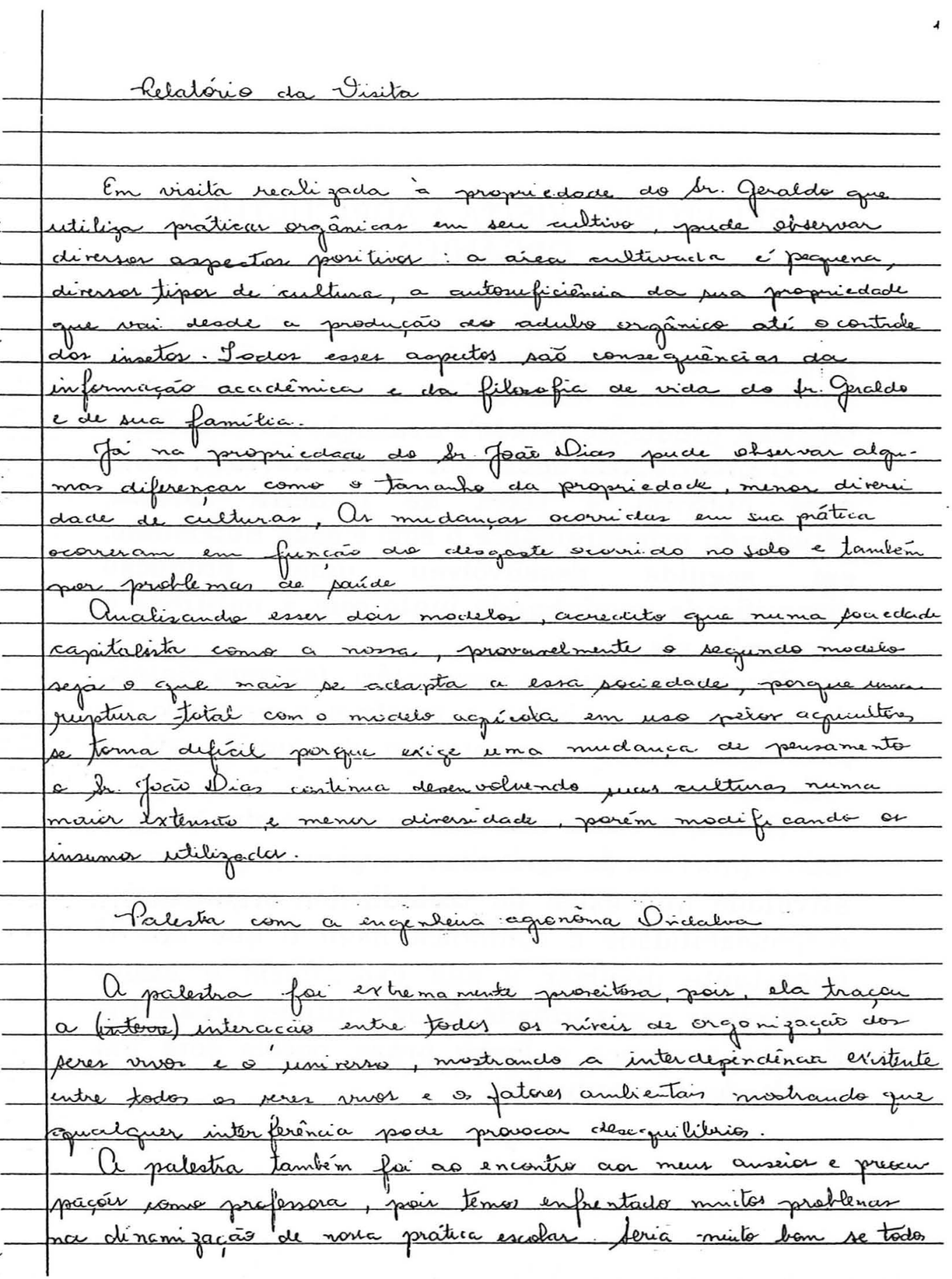


APÊNDICE 10 - CONSIDERACÕES SOBRE UM ESTABELECIMENTO DE PRODUC̄̃̃O ORGÂNICA FL. 1 de 6

Atividade: Visita ao estabelecimento do produtor orgânico G. Transcrição de trechos da fita cassete

(Obs.: Onde aparece números entre chaves indica dúvidas no momento transcrição).

G- Quando a gente se propõe a fazer esse trabalho, não é só plantar, colher e vender.. ele é algo a mais. O quê é? É plantar, colher, vender, viver disso ... porque a nossa idéia é viver com qualidade, a nossa mudança para cá, teve esse objetivo, de largar São Paulo, e fazer uma outra coisa que tivesse assim, vamos dizer, que para nós tivesse mais valor, que pudéssemos ter mais prazer, ter satisfação em fazer... Então quando nós nos propomos a isso, nós viemos e acho que a idéia é passar isso, além de fazer, poder estar divulgando, e fazendo com que as pessoas entendam, promovendo uma mudança, uma transformação. É promover assim, vamos chamar de educação, participar do processo educativo, que nós perdemos ao longo do tempo uma série de valores que precisamos retomar, porque se nós não retomarmos, eu acho que em breve nós teremos, nós já estamos vivendo um processo muito sério de crise, uma crise generalizada e parte dessa crise é conseqüência da nossa interferência no meio ambiente, na Terra. Nós temos como objetivo também participar desse processo, nós não somos agricultores, nós somos aprendizes de agricultores, mas nós queremos ser mais que agricultores, nós queremos promover uma mudança, uma transformação, nós queremos participar desse processo, que é um processo muito lento.. embrionário ainda, mas nós temos como objetivo isso, e, para isso nós fazemos esse tipo de coisa, nós recebemos pessoas, nós vamos a locais, fazemos palestras, conversamos sobre isso. então é normal já, esse tipo de coisa.. por ser algo diferente, que não é comum, ..nós temos pouquíssimos agricultores orgânicos .. ainda dentro.. dentre os agricultores orgânicos, nós temos um número menor ainda que tem essa preocupação.. muitas vezes, o agricultor orgânico, ele tem, como objetivo, produzir e vender por um preço melhor.. e às vezes, ele não tem muita noção dessa.. relação com o meio ambiente, com essa relação com a vida, mesmo.. então, nós temos essa preocupação.. e sofremos um pouco por isso, porque muitas vezes, nós deixamos de produzir.. deixamos de vender.. de ter um rendimento maior, para fazer esse trabalho, para.. fazer esse trabalho de divulgação, ou mesmo de investimento, assim no.. investimento no solo, na terra, investimento.. no projeto como um todo.. então não é uma coisa meramente comercial, ela tem um outro fim.

( $G$ fala do seu processo de decisão de mudança para agricultura orgânica)

G (...) Nós só estamos aqui na produção é esse o nosso objetivo, cada vez mais ficar aqui . O processo produtivo em si, ele é muito complicado, muito difícil às vezes, as pessoas não imaginam as dificuldades que irão encontrar na produção.. principalmente com uma atividade, vamos dizer, diferenciada, que é essa. É muito diferente a agricultura convencional da agricultura orgânica. Porque tudo está montado, preparado, para a agricultura convencional. A agricultura orgânica, é uma excessão, ela é diferente, nós não temos implementos, insumos. Sim, nós já estamos começando a ter.. mais facilidades, o mercado já está se preparando para isso, ele já está respondendo para isso .. mas, não é muita coisa ainda.

(...)

G- (...) O agrotóxico, ele é cruel. Ele é cruel, por quê?.. Porque ele mata aos pouquinhos, é para que não tem pressa de morrer. (pessoas falando) O processo de intoxicação ele é gradativo, ,, os casos de intoxicação que levam para matar no hospital, eles são até que pequenos. Mas, se você pegar todo o agricultor da região que mexa com agrotóxicos, se você mandar uma..

(?)-É o histórico também..

G- Mandar fazer um exame, por exemplo, dá para fazer. Você coleta sangue e manda para o Adolfo Lutz, eles fazem.. é possivel fazer esse tipo de coisa, para você ver $o$, a quantidade de residuo de veneno que tem no organismo da pessoas.. então toda a pessoa que lida com agrotóxico, você pode mandar fazer uma análise sangüinea, que você vai ver que os niveis de contaminação são altos.. assim, é comum na região, morrer pessoas com câncer, o sogro do meu irmão morreu com 55 anos.. de idade, com vários tumores, e principalmente tumor no figado.. morreu a pouco tempo, 1 ano e meio atrás, 2 anos atrás.. e ele era batateiro, camarada que planta batata há 30 anos..

V-Batata é outro grande usuário de produtos químicos .

G- Sim, as pessoas usam, é veneno para tudo, eles acham que não conseguem produzir sem veneno Está provado cientificamente que $80 \%$ a $90 \%$ dos agrotóxicos que se usam, não tem efeito, não surte efeito, se o agricultor não usasse. (...) Seria a mesma coisa. Assim, falta educação,., as pessoas até tem um certo nivel de informações, mas falta o processo educativo que é as pessoas utilizarem,,, as pessoas se convencerem daquelas informaçöes que 


\section{APÊNDICE 10 - CONSIDERAC̄õES SOBRE UM ESTABELECIMENTO DE PRODUÇÃO ORGÂNICA FL.2 de 6}

elas tem Então, é, nós estamos assim numa situação onde.. descontrole total. Na Europa é assim?.. Nos Estados Unidos é assim? Não. (palestrante cumprimenta um funcionário). Eles respeitam. (...).

G- É, assim, o grande mercado dos agrotóxicos.. são os países pobres, países periféricos, então o Brasil é o maior consumidor de agrotóxico do mundo.. tem uma grande extensão territorial livre-. Tem uma grande produção agrícola. Agrotóxico não é um problema só para as plantas. Os venenos também são problemas para os animais, ovos, leite, carne, tudo isso, está contaminado por produtos químicos, então as pessoas utilizam veneno para moscas, vermífugos, todas essas coisas, indiscriminadamente (...) (Comentários sobre agrotóxicos)

V- (...) Os químicos ..., são ruins.. eles tem um monte de efeitos maléficos. E ai você está tentando uma coisa diferente, fala um pouquinho dessa coisa diferente que você está tentando..

(Uma pessoa pergunta sobre vinculação entre agricultura orgânica e criações animais)

G- Sim, aqui nós fazemos isso..

(?)- A associação, não é?.. (pessoas falando)..

G- É, assim, uma coisa é você transformar o agricultor convencional, você fazer uma substituição (...), você pega um, ele usa um herbicida, ai você fala para ele, "não, você não vai mais usar herbicida, você usa o plástico" Você usa um veneno para fungos".. então você vai usar um outro tipo de produto para controlar os fungos . Não, a agricultura orgânica não é uma mera substituição de insumos.. por quê?.. Porque ela tem características diferentes (...), o agricultor convencional, quando ele é convertido para a agricultura orgânica, então muitas vezes ele faz isso, ele simplesmente muda o tipo de insumo que ele utiliza, è o tipo de manejo.. vocês irão visitar o (outro produtor), vocês irão verificar que (ele) era um agricultor convencional, que se transformou em um agricultor orgânico, mas o quê que ele fez?.. O sítio dele não tem uma diversidade de produção, ele não tem uma preocupação mais assim, geral, uma preocupação ampla, com o sistema produtivo.. com a sua relação com a terra.. então muita, daqui a pouco, o que vai acontecer, é que você vai ter um agricultor orgânico de alface, um agricultor orgânico de cenoura, um agricultor orgânico disso, daquilo, de soja .. então como o mercado vai crescendo, ele está crescendo muito rapidamente, então a tendência é você ter esse tipo de coisa.. mas aí..

V- E você está tentando uma coisa diferente! (pessoas falando)..

G- É isso mesmo, agora o nosso objetivo é diferente, nós temos um objetivo de viver disso aqui, viver aqui, e ter o máximo controle possível, sobre as coisas que nós fazemos, que nós consumimos, então eu quero para a nossa, para a nossa realidade aqui, que nós consigamos produzir ovos, que nós consigamos produzir leite, que nós consigamos produzir as verduras, os legumes, para quê?.. Para que nós tenhamos o máximo de controle possivel, sobre aquilo que nós usamos.. sobre aquilo que nós consumimos .. e mesmo, para que você tenha uma relação, vamos dizer assim, mais eficiente em relação ao meio ambiente, porque quando você se torna um produtor de alface, mesmo que seja dentro das técnicas orgânicas, o quê que está acontecendo?.. Você está simplesmente mudando as técnicas. Mas você não está investindo, sabe de fato, naquele seu ambiente, no seu meio ambiente, investindo na sua própria vida, na sua própria qualidade de vida, porque uma pessoa que só produz alface, então ele vende alface, ele vai comprar tudo. Ele tem acesso a esses produtos orgânicos para ele comprar?

G- Ele não tem.. então..

(?)- Ele está querendo resgatar, o que tinha.. (pessoas falando)..

G- Exatamente, há 30 anos atrás, 40 anos atrás.. as pessoas, o agricultor ele vivia na roça, morava na roça, ele tinha.. o porco, a galinha, a vaca, o queijo, os ovos, quer dizer, ele produzia, ele produzia o arroz, o feijão, o milho, ele tinha uma gama maior de produção, uma diversidade, mas a preocupação dele era primeiro a sobrevivência, depois o comércio.. então esse valores foram mudados, então hoje, o agricultor primeiro, ele se preocupa em vender, depois ele se preocupa em comer.. então, o quê que está acontecendo?.. Houve uma queda brusca de qualidade, o camarada hoje , o que ele faz?.. Ele vende alface, e busca Coca-Cola, arroz, feijão.. tudo..

(?)- Um franguinho congelado..

G- Tudo, no mercado, compra batata frita em saquinho.. absurdo!.. Esse processo que é um processo de vamos dizer assim, de degradação do homem, porque ele passa a consumir muito menos qualidade, o que ele tinha de qualidade lá, ele vendeu tudo, ele acabou.. e o meio ambiente, como é que fica?.. É quando vocês vão a um sítio que tem uma produção diversificada..

(?)- Você não vai ver isso.. 
APÊNDICE 10 - CONSIDERAÇÕES SOBRE UM ESTABELECIMENTO DE PRODUÇÃO ORGÂNICA FL. 3 de 6

G- Vocês vão ver uma paisagem, certo?.. Quando vocês forem a um sítio que tem uma produção, é uma monocultura, vamos dizer assim, ou quase isso, vocês verão outra paisagem.. vocês verão uma coisa devastada, limpa, completamente.

(?)- (pessoas falando).. (..-333) A força do capital que é a imprensa, pode colocar a agricultura orgânica como algo saudável, mas todo o restante da imagem que a televisão trabalha é contra aquilo..

G- Exatamente..

(?)- Então, é assim meio folclórico, vamos dizer, nós trabalharmos em cima disso quando toda a sociedade vive em cima do consumismo.. Então, a televisão faz uma reportagem valorizando a organocultura, só que na realidade todo 0 restante do trabalho da televisão está indo contra..

(?) Eexatamente, por isso que eu falo que é uma coisa embrionária, é remar contra a maré..

(?)- Totalmente.

G- Eu vou falar para vocês do crescimento da agricultura orgânica, a agricultura orgânica ela cresceu, ela deu um salto enorme nos últimos 2 anos.. (Comentários sobre o crescimento da produção orgânica na grande São Paulo e do papel da empresa Horta e Arte). No geral, o total de produção orgânica que é vendida hoje em São Paulo, é uma coisa pequena ainda, é muito insignificante, não é verdade?.. E tem outro fator restritivo que é a questão do preço, o produtor orgânico ele é bem remunerado, eu acho que os preços que conseguimos hoje, são bons, não podemos reclamar dos preços, comparando com o preço que o produtor convencional recebe, vou dar exemplo para vocês, hoje uma caixa de alface deve estar custando por volta de 5 reais, não é isso?.. 5 reais uma caixa de alface com 24 ou 32 pés, se for pés grandes, 24 , se for 32 , pés menores.. então, quanto custa o pé de alface?..É dividir 5 por 30 , vamos supor, quanto custa isso?.. 0,06 centavos.. um pé de alface, nós vendemos por $R \$ 0,50$.. é bem diferente, só que nós vendemos um pé de alface, com uma característica totalmente diferente, são produtos muito diferentes, na sua qualidade interna, certo?.. $E$ mesmo na apresentação.. o pé de alface que vendemos, geralmente, ele é um pé de alface limpo, sem folhas podres, e não está todo amassado.. ele é lavado em 2 águas, quer dizer, tem toda uma preocupação, é uma coisa feita artesanalmente.. o agricultor convencional não, ele vai cortando, socando na caixa, (...), põe no caminhão, vai embora para o CEASA.. é outra coisa..(pessoas falando)..

(?)- (...)Você não vai levar em conta o gasto médico comendo o convencional, não é?.. (pessoas falando)..

(?)- As pessoas, às vezes, acham melhor não pagarem $R \$ 0,50$, eu prefiro, quanto eu vou economizar as minhas idas ao médico?.. E outras coisas, e comendo um sabor.. (término do lado $A$ da fita)..

\section{Lado B}

(Comentários sobre adubação quimica e natural)

G- (...) Os nossos solos são pobres em micronutrientes, muito pobre, então nós usamos micronutrientes, nós usamos a forma primária do produto que são os farelos de rocha, certo?.. Então nós não usamos sintéticos, não usamos produtos elaborados, nós usamos, geralmente, os produtos primários e de baixa toxicidade. (...) Hoje, nós temos tecnologia para isso, por exemplo, nós usamos calda bordalesa, que é sulfato de cobre com cal e água, isso é cal da bordalesa, ela é pouquíssimo tóxica..

(?)- Para matar praga, não é?

G-É, nós usamos como fungicidas..

(?)- (A idéia-043), não para matar, é para espantar, não é?..

G-É, o cobre, ele é fungistático, não é?.. Então quando você pulveriza o cobre, ele cessa o processo de reprodução dos fungos, nos usamos outros recursos, por exemplo, calda de pimenta.

(?)- Pimenta?..

G- Pimenta.. você pulveriza uma calda de pimenta nas plantas, e o que acontece?..Os insetos se afastam, eles não gostam, outro recurso, por exemplo, consórcios, você faz o consórcio de determinadas plantas com outras plantas que elas são repelentes a insetos, por exemplo, o coentro, os insetos não gostam de coentro, nós plantamos a celga, ela é muito..

(?)- Você tem que conhecer profundamente cada vegetal no caso.. 


\section{APÊNDICE 10 - CONSIDERAC̄ōES SOBRE UM ESTABELECIMENTO DE PRODUÇÃO ORGÂNICA FL.4 de 6}

G- Exatamente.. é o que cada agricultor deveria fazer, independente do tipo de agricultura (que ele faça-pessoas falando-055).. só que o agricultor convencional, o que ele faz?.. Ele vai na loja, a pessoa mostra para ele a variedade da semente e já passa o adubo, e fala assim, "você vem buscar depois o veneno" .. (pessoas falando)..

(?)- Dá a receita..

(?)- Essa calda de pimenta, como é que faz?

(Geraldo comenta o uso de pimenta, alho e outros produtos naturais como insumos na agricultura)

G- Com certeza, o mais importante, é nós investirmos no solo (...) Uma outra coisa, eu tenho uma produção animal, nós temos as cabras, as vacas, as galinhas, então a quantidade de matéria orgânica que nós geramos aqui, ela é grande, então eu posso colocar a matéria orgânica no meu sítio, a quantidade a vontade, diferente de um outro agricultor, mesmo orgânico, que ele tem que importar para o sítio dele a matéria orgânica, ele tem que trazer de fora. (...)

(?)- Usam animais, é como tem uma determinada época que se toma difícil para custear alimentação deles, como é que você faz?.. Por exemplo, na época da geada?.. Como é que você faz para manter a alimentação dos animais?.. Cabra, vaca..? (O palestrante vai atender um telefonema).

(?)- $E$ os animais, a vaca, a cabra, principalmente nessa época, porque enquanto tem verde você, lógico que você não dá só o verde que você tem no seu sítio, você tem que enriquecer com algum outro produto..

G- Deixa eu explicar (...) Nós vivemos num país que é uma dádiva, não é verdade?.. Nós temos ai os eventos extremos aqui, que são quase inexistentes.. mas nós temos as geadas, os ventos, tempestades, alguma coisa assim, mas isso é muito pouco, isso acontece pouco aqui, comparando com outros paises, nós temos condições perfeitas, quase perfeitas aqui, mas temos a geada e no período do frio, nós temos a redução da produção da massa verde, mas o quê que nós fazemos? .. Como somos pequenos, como o nosso caso é um caso pequeno, nós temos poucos animais, então por isso essa preocupação com a diversidade, com a diversificação, porque se eu inventar de criar só vaca aqui, com certeza eu vou ter esse tipo de problema, vaca confinada, por exemplo, porque a minha área é pequena, então se eu quiser ter só vaca, vai chegar na seca, eu vou estar no desespero, mas não, eu tenho 1 vaca, eu posso ter até 3 vacas, o quê que eu faço, eu tenho uma vaca muito produtiva, em vez de ter uma pé-duro, uma vaca que produz pouquinho, não, eu tenho uma vaca, assim não é muito mas eu considero de produtividade boa, ela me produz cerca de 20, 25 litros de leite, então nós temos vaca de 60 .. (risos).. então é em média, ela produz até menos, assim, eu tenho cabras, nós chegamos a ter 40 cabras, são animais que comem pouco, e que dá uma produtividade alta, aí o quê que acontece?.. A minha horta ela é produtiva o ano todo, mesmo se vir uma geada, a geada vem, mas eu tenho uma produção, porque a horta é rápida. (...) Como nós lavamos, limpamos as verduras antes de mandar, então tem uma sobra alta, então toda essa sobra vai para o coxo, nós fazemos um silo, nós temos um silo que nós guardamos na época que tem, nós cortamos, trituramos e deixa no silo para usar na seca, e outra coisa, os nossos animais, eles comem tudo, então todo o tipo de mato, tudo o que é verde aqui, cortamos e levamos para o coxo, eu roço, então pode ver que no meio das árvores, o mato cresce, na hora que ele chega um certo tamanho, eu venho com a roçadeira e levo tudo para o coxo. A suplementação mineral que é de extrema importância, esse não tem jeito, vem de fora, tem que comprar, nós temos o seguinte cuidado de comprar um suplemento mineral que não tenha coquixidiostáticos, que não tenha antibióticos, e que não tenha promotores de crescimento que são hormônios, que são prejudiciais a nós, então nós temos uma empresa no interior de São Paulo, que formula, especialmente, nós não compramos ração comercial, eu não vou na loja e compro um saco de ração, porque seu sei que tem todos esses produtos prejudiciais, tem uréia, então nós temos esse cuidado com os animais. Milho, farelo de trigo, farelo de soja, essas coisas, nós compramos, nós usamos o mínimo, mas não tem jeito, nós não temos ainda soja orgânica, nós não temos milho orgânico..

(?)- Então por isso que eu perguntei, veja bem, o nosso milho, ele é produzido de uma maneira...

G- Convencional..

(?)- Como qualquer outro produto, não é?..

G- Exatamente. Nos temos uma idéia, nós estamos caminhando para isso, nós temos um objetivo de chegar a uma produção que os orgânicos, que tem pessoas que produzem organicamente, para produzir milho, soja, para abastecer os orgânicos, para nós termos acesso a esses produtos, para ser tudo orgânico, só que vamos levar tempo para chegar lá. (?)- É um processo lento..

G-É um processo lento, então eu acho que nós já caminhamos bastante..

(?)- O quê que é isso daí? 
G- Aqui nós temos abelhas também, aqui é uma propriedade que tem.. nós temos a abelha, os animais, as verduras, então, essa abelha é uma abelha curiosa, eu deixei aqui só por ser uma..

(?)- Só para que nós perguntássemos?

G- Só para todo mundo perguntar, é só para dar o que falar, essa é uma abelha que nós chamamos de Abelha de Rapina, é uma abelha sacana, ela sacaneia as outras, ela saqueia as outras abelhas, aqui tinha uma colmeia de Jatai, então ela veio e invadiu a casa da Jataí, matou a colmeia de Jataí e se instalou aqui, então ela tem todas essas pontas que é para enganar as outras, é uma forma de proteção, porque quando elas atacam uma colmeia, como uma colmeia de abelhas européias (fertanizadas-180), elas vem e entram, e as outras vem atrás, e elas fecham a entrada principal, e as outras abelhas não sabem aonde é que é a entrada.. (pessoas falando).. então vamos visitar, vamos começar, o trabalho da horta, ela começa aqui nessa bancada que é aonde nós fazemos as mudas, o subextrato para as mudas, nós ainda compramos, nós queremos chegar num sub-xtrato, porque nós colocamos, para colocar na bandeja, para fazer nas mudinhas, mas ainda não conseguimos um sub-extrato bom..

(?)- E as sementes?

G- As sementes, nós não temos sementes orgânicas, ainda, então nós compramos a semente com veneno, infelizmente, nós não compramos mudas já prontas, porque já tem uns viveiros por ai que vendem mudas, mas eles usam muito fungicidas, inseticidas, essas coisa, então nós não compramos, e mesmo os adubos, são químicos.. eles utilizam nos viveiros, então nós temos que produzir, o agricultor orgânico ele tem que produzir a muda, já tem alguns viveiros produzindo mudas orgânicas, já tem alguns produtores de muda orgânica que são certificados pela associação, direitinho.

V- Alguns assentamentos no Rio Grande do Sul, estão começando a produzir sementes e mudas, não è?

G-É, já tem ai um inicio..

$\checkmark$ - Acho que até por aqui começa a ter.

G- Nós precisamos, a semente é muito importante, nós precisamos de semente de boa qualidade, para isso, nós vamos demorar um tempo ainda para ter sementes orgânicas de boa qualidade, porque tem todo um processo de seleção, questão aí, você não consegue uma produtividade boa, então se a coisa começa mal..

(?)- Não pode perder a produtividade, não é?

$\mathrm{V}$ - O problema é que, eles são pesquisadores ao mesmo tempo que são produtores..

G- Temos que ser, é interessante observar uma coisa, qual é o agricultor convencional que vocês irão aí, que mora na roça, que tem uma gama de informaçöes assim?.. Não tem!.. As pessoas não tem informaçöes, as pessoas não sabem direito como eles tem uma informação que passou de pai para filho e tal, eles tem uma cultura de produção..

(?)- Mas não tem um estudo assim..

G- Mas eles não sabem direitinho como é que funciona, eles não conseguem ter uma idéia geral do processo, geralmente, o agricultor convencional, o orgânico, ele tem mesmo assim, tem uma diferença, tem as pessoas que se preocupam mais e tem as que se preocupam menos, mas geralmente, o agricultor orgânico, ele tem mais informaçōes..

V- Que negócio é esse?

G-Isso aqui é um micro trator, (pessoas falando- .usam para-226)..

$V$ - Eles poderiam tudo um trator maior, mas com isso dai..

G-Vocês irão no João Dias, vocês verão um trator maior.. uma coisa interessante é que, o sítio, ele é uma coisa complexa, é muito..

(?)- Também se tiver um trator não dá para ter árvores, não dá para ter essas coisas que você tem, fica impossivel.

G- Vocês vão ver a bagunça aqui, assim, eu tenho um sonho de um dia eu organizar tudo.. mas por enquanto não está dando tempo.. vamos dar uma olhada no viveiro?..(pessoas falando).. Assim .. (desliga gravador).. a horta a mesma cisa, o agricultor convencional ele não se preocupa muito com isso porque ele planta por safra, então ele vai lá, ara tudo (238), planta só cenoura, colheu a cenoura, ai ele já pensa no que ele vai plantar depois da cenoura, ara tudo, planta aquela coisa, vende, ara tudo, planta, nós não, nós somos diferentes, como nós temos um mercado restrito, um mercado pequeno, então o que nós temos que fazer?. Nós temos que ter variedade, que tentar mais coisas, e colher toda a semana, porque nós vendemos em pequenas quantidades, então se nós plantarmos e encher tudo aqui de alface, com certeza eu vou perder $80 \%$ da alface, vou encher tudo de cenoura, eu vou perder a maior parte, então o quê que eu tenho que fazer?..Eu tenho que diversificar, e como é que faz isso?.. Eu tenho que colher toda a semana, eu não posso 


\section{APENNDICE 10 - CONSIDERAC̄ÕES SOBRE UM ESTABELECIMENTO DE PRODUCÃO ORGÂNICA FL.6 de 6}

plantar por safra.. eu não posso plantar um pouquinho de cada coisa, sem tudo, ai colhe tudo de uma vez, vende depois planta tudo de novo, não tem como, não é funcional, então o quê que eu faço?.. Eu seleciono algumas culturas, com preferência com aptidão de clima, para que eu tenha menos problemas, menos pragas, para conduzir a cultura e ai eu vou fazer um cronograma de plantio e de manejo de colheita.

(?)- Para não ficar desabastecido.

G- É, então nós anotamos tudo, tem que ser tudo anotado porque senão nós não conseguimos controlar, então mesmo o preparo do solo, nós temos um controle de todo o preparo do solo, o que nós colocamos o quanto colocou, porque senão, você perde o controle, você não sabe o que você colocou, e coloca de novo, ou você deixa de colocar e falta a planta. Nós temos assim, uma planilha (...) Eu vou anotar tudo, a data que eu plantei, que eu coloquei a cultura, o tipo de adubação que eu coloquei, se eu fiz uma correçäo com fosfato ou com calcário, tudo isso, nós vamos anotando na quadra, no local, que quando eu for fazer o próximo procedimento para aquele canteiro, eu tenho que saber o que eu fiz antes, para fazer a rotação de cultura, para ter todo esse controle, então é um negócio bastante complexo. (..) Eu quero colher 400 escarolas por semana, certo?.. (...) isso é o planejamento anterior, (...) o espaçamento para orientar quem vai fazer lá, quem vai plantar, área, para se ter um controle e fazer a coisa certa. (...) Tem que ter um controle total para funcionar, caso ao contrário, não funciona, nós não conseguimos fazer funcionar, assim, é um aprendizado duro, difícil, porque tem muitas variáveis de clima, de falta de informaçōes, erro, você erra las vezes, no plantio, às vezes, não dá tempo, chove, você não consegue preparar o solo, a muda passa, às vezes, problemas na muda, quer dizer, você tem muitas variáveis que complicam o nosso, que embola o meio de campo, mas é, eu tenho que adquirir essa cultura de agricultor, eu tenho que me transformar num agricultor, e um agricultor que, diferente, que tem que enxergar tudo isso, na verdade, todo o agricultor deveria saber, deveria ter o controle de todo o processo, então, ele não cometeria os erros de usar um veneno que não serve para nada, de misturar um veneno com um outro, que um anula o efeito do outro, que é muito comum, eles fazem os coquetéis de veneno, então eles misturam tudo, colocam numa bomba e pulveriza, ai um neutraliza o outro, um toma, vamos supor, aumenta a acidez, o outro reduz a acidez, então, se as pessoas tivessem essa noção de conjunto, nós economizaríamos muito dinheiro, seria muito mais eficiente e teria menos problemas com esses produtos que consumimos, é uma área de extrema importância, alimentação é fundamental..

(?)- Então as pessoas que trabalham com você, tem que ser bem orientadas..

G- Tem que ser bem orientadas..

(?)- Porque não tem essas informações antes, tem que..

G-É, assim.. a nossa grande dificuldade..

(?) - Na realidade, (precisam ter um grau de escolaridade-370) para ler e entender..

G- Esse é o ideal; o ideal seria que nós trabalhássemos só com técnicos agrícolas, pessoas que tivessem informações anteriormente.. (pessoas falando)..

V- (...) eu já vi planejamento onde o agricultor não sabia escrever, ele tinha desenho e simbolos que jele entendia (pessoas falando). (...)

G-É interessante isso, agora assim, o que nós precisamos é elevar o nosso nivel escolar.. eu acho que nós temos que brigar para que isso aconteça.. e inclusive elevar o nosso nivel cultural.. eu acho que está muito relacionado a ..

(?)- E mesmo os próprios agricultores, eles acham que não precisam estudas tanto.. (pessoas falando)..

G- Para trabalhar na roça.

(?)- Aqueles que trabalha com uma pessoa que tem que abraçar realmente, tem que aprender, a amar aquilo que você, (a realidade-397), porque caso contrário, fica difícil trabalhar com uma pessoa que não valoriza aquilo..

G- Exatamente.. o homem da roça, ele tem por cultura, desvalorizar o seu trabalho.. por exemplo, eu nasci na roça, eu nasci na fazenda, eu nasci de charteira. e assim, o grande sonho da minha mãe, da minha família, era fazer com que nós estudássemos para não fazer o que eles faziam.. é uma negação dos próprios valores.. que são os valores burgueses, não é verdade?..E que vem desde a Idade Média. fim da Idade Média, então que é uma negação, então, são tantos anos com esse tipo de rejeição que fica dificil mudarmos isso de uma hora para outra, precisou que eu fosse para uma universidade, que estudasse, que tivesse todo um conhecimento.. para que eu conseguisse entender esse processo e fazer essa retomada. então é muito importante que nós valorizemos aquilo que nós temos, eu acho que vocês, como professores, como pessoas que lidam com jovens em formação.. é, está tudo nas mãos de vocês, eu vou me incluir, eu acho que estão tudo nas nossas mãos.. eu acabo fazendo muito esse trabalho também, ontem por exemplo, é anteontem.. (término da fita).. 
APÊNDICE 11 - AVALIACÃO RÁPIDA DAS ATIVIDADES DO DIA FL. 1 de 2

AVALIAÇÃO RÁPIDA DAS VISTAS AOS PRODUTORES ORGÂNICOS / $3^{\circ}$ ENCONTRO - 17/04/1999

(..)

(Vitor) Eu estava querendo que refletissemos um pouquinho (sobre as visitas): Se foi bom? Se valeu?

(??) Ah sim!

(??) Valeu a pena!

(m) Nossa!

(Rosalina) Foi um dia bem aproveitado!

(Amélia) Apesar do cansaco, valeu!

(Lobo) Eu estou todo pregado.

(Jade) Seria bom se todas as hortas fossem assim...

(Muitas pessoas falando simultaneamente. Vitor pede para uma das participantes repetir seus comentários.)

(Safira) Até agora ótimo, maravilhoso, eu vi, gostei, parabéns. E depois, o quê que nós professores vamos fazer para que isto vire um embrião para crescer?

(Ceci) Como aplicar?

(??) É ? (Outros cursistas reiteram o mesmo questionamento.)

(Safira) Eu trabaho dentro da área há vinte e tantos anos e me considero fracassada. É verdade. Então ai é onde eu questiono, eu coloquei no texto também. ... No momento é muito bonito, entusiasmador, mas você fala, faz e aquilo não dá em nada. Pode até ser que esteja dando em algum lugar mas a gente não tem retorno. Então ...

(Rosalina) Mas eu acho que não é uma área fracassada, tanto é que nós estamos vendo hoje os efeitos, está comecando...

(lara) Mas eu acho que ela conseguiu (fazendo uma referência ao trabalho desta professora).

(Amélia) Talvez seja preciso muita degradação para o homem voltar a pensar...

(Safira) Como passar para o aluno de maneira que sensibilize?

(Rosalina) Aqui no caso é aluno que está trabalhando. (Referência aos filhos do produtor $\mathrm{G}$ os quais foram alunos de alguns dos professores.)

(Vitor) Mas ele não entrou neste processo via ensino formal.

(Cameiro) É foi via propriedade do pai.

(Amélia) Como fazer o caminho inverso da esoola p/a comunidade?

(Safira) Principalmente agora que a midia é muito forte e a ilusão de uma vida melhor é o sonho de todo jovem. Esse jovem, como a gente faz $\mathrm{p} /$ convenceto a retroceder no tempo e mostrar que foi melhor, que è melhor e que tem que voltar?

(Amélia) O problema é este conceito de melhor.

(Safira) Enquanto a tecnologia está descobrindo outros planetas e sistemas solares..., nós vamos arancar mato com as mãos? Então é este lado que eu questiono: mostrar para o aluno ele sentado num tratador bacana passando em cima de tudo ou ele agachado rancando o capinzinho. Como traduzir isto em sentimos que gere na criança a vontade de mudar?

(Vitor) Este é o nosso grande desafio.

(Interupção da avaliação por alguns momentos.)

(Vitor) Mas sobre hoje, a Safira falou: 'Hoje por enquanto foi tudo bonito' ...

(os cursistas começam a falar)(???) É tudo bonito,

(Ceci) O problema é passar isto para o papel, para um projeto e que a gente tenha um retorno

(Safira) Que tenha compromisso...

(Lobo) Resultado...

(Safira) Que seja algo que realmente ponha raizes. Porque a gente trabaha na ilusão: "eu fiz", mas sentir que enraizou eu acho que é a questão que a gente tem que buscar.

(Vitor) Nós teremos 6 meses para conversar sobre isto... (os cursistas continuam falando)

(Jade) Como passar para os alunos?!

(lara) Eu acho que é: como passar para a comunidade? (Várias pessoas falando.)

(Cameiro) O G falou que há muitos agrônomos que "tiram sarro" deste sistema ... 
(Safira) (Continuando sua fala) Educação sexual todo mundo gosta, presta atenção, sabe, nota dez na prova: "-Você usa camisinha ?" "-Ah! Professora eu não vou perder chance com uma gata desta."... Aí pronto, foi embora tudo o que ele disse que sabia. É este lado que me entristece muito.

(lara) No papel tudo fica ... mas..

(Rosa) O que faremos depois de tudo isto?

(Safira) Então tem que ser como o senhor João: 'investir sem retorno', mas 'mergulhado de cabeça' como o G. É muito dificil, muito dificil. Por que? Porque a gente faz parte de um sistema que não está remando para lá, a gente faz parte de um sistema que está indo para outro lado.

(Jade) Davi contra Golias né?!

(Cameiro) Pelo menos a gente também teve uma idéia. (... Até a década de 60 e mesmo até 75 este tipo de coisas que eles estão fazendo, existia. A gente está vendo a possibilidade de reverter e não precisa ser $100 \%$ mas de $40 \%$ de imediato, existe. Vemos os produtores comentando as vantagens, os beneficios e o otimismo deles, que se não houver contratempo econômico dificilmente eles voltarão ao sistema antigo. Então conforme ele falou os vizinhos estão começando e vai chegar uma hora que a senhora vai chegar nos supermencados e falar ao gerente: '-Cadê os produtos orgânicos? Então o gerente vai começar a fazer o quê?

(lara) Comprar os produtos.

(Cameiro) Então a gente tem também que pressionar os donos de supermercados e perguntar. ' vocês não trabalham com produtos orgânicos? Um pergunta, outro pergunta, até que uma hora ele se enche e fala vamos aos produtos orgânicos $e$ as coisas vão tender a reverter.

(Jade) Pressionar como consumidores?

(Muitas pessoas falando ao mesmo tempo, concordando ou completando a idéia anterior.)

(Jade) Educação do consumidor também é importante.

(Rosa) Todo professor tem uma particularidade: ele pensa que vai mudar o mundo. Acho que é o grande sonho.

(Safira) Eu sou filha de agricultor que trabalhou na enxada e que pouco-a-pouco foi mudando, sempre na busca de sobrevivência neste mundo. Este ano, estou fazendo uma volta p'ra ... e na granja da família, por sua vez, este ano comemoramos a mecanização total . Então eu estou vivendo 2 mundos: eu venho reunião num sábado aqui e no outro sábado: visitando a mecanização total. Eu tô com um pé lá, pé cá.

(lara) Dois opostos, né?

(Safira) Eu levo um pouco da mensagem daqui para lá e ... (traz de lá) é dificil isto.

(Cameiro) Viu dona Safira a mecanização em si, não podemos ter como influência negativa, temos que ter a mecanização mas sem (...) os venenos.

(Rosa) A sim, não associar.

(Safira) . Por exemplo agora estão criando galinhas numa câmara dark house,(...) não vê luz solar (...) criação totalmente sem luz, com lâmpada,, sei lá que lâmpada que é. E a galinha fica tranquiila, não quebra ovos, não tem stress. Então são situaçöes assim, né!

(Várias pessoas falando, comentando a situação.)

(Lobo) Hoje vai lá, vê os frangos soltos, ambiente em equilibrio...

(Safira completando a frase) )...a galinha só ciscando aqui, ali ${ }_{\text {, }}$, e a galinha que nunca pisou no chão.

(Risos, clima descontraido, vánias pessoas rindo e brincando)

(Rosa) Ese trouxer estas galinha para conversar para ver o que elas acham da idéia? (Risos)

(Cameiro) Elas não vão poder opinar nunca tiveram em outro lugar.

(Vitor) Mas geralmente só de olhar para os bichos, você vê o bicho confinado parece que sente,, a tristeza.

(Cameiro) Mas se já nasceu ali, Vitor... (Risos)

(Vitor) Mas eles ouvem falar...(Risos)

(Lobo) É a globalização.(Risos). 
APÊNDICE 12 - AVALIACÃO E EXPECTATIVAS SOBRE O CURSO FL.1 de 9

\section{AVALIAÇÃO E EXPECTATIVAS DOS PARTICIPANTES SOBRE O CURSO TRANSCRIÇÃO DE FITA DE VÍDEO / $6^{\circ}$ ENCONTRO 6 / 22/05/1999}

1. (Vitor) (..) Vamos começar o segundo módulo do curso. (...) Vamos avaliar o curso (...) Podemos pensar este nosso curso como um barquinho em que estamos todos juntos fazendo uma viagem. Podemos pensar como foi esta viagem, pontos positivos e pontos negativos e onde esperamos chegar nesta viagem, (...) ou o que estamos esperando deste barquinho chamado curso...

(Vitor passa para uma das cursista, um barquinho de papel que ele preparou enquanto falava.)

2. (Rosa) (...) Eu acho que está sendo muito bom, diferente, realmente uma mudança de pensamento, trazendo uma mudança de atitude. Fico um pouco preocupada diante do que a gente viu aqui, (...) de todas as coisas que a $O$ disse p'ra gente (...) diante de todos problemas que temos que enfrentar, (...) eu sou sonhadora o tempo (...) e a gente pensa num mundo melhor para mim, melhor para meus fulhos, a gente pensa no poder que as pessoas têm mas mãos e não fazem nada para melhorar (...) É o que mais me deixa preocupada é que eu quero perdoar, eu quero melhorar, eu fico percebendo que o mundo é muito maior e eu me sinto impotente. É bem por ai, achando ótimo o curso. Eu acho que é isto.

3. (Vitor) (...) Eas coisas ruins?

4. (Rosa) Eu não vejo.

5. (Vitor) Então o que não foi tão bom? ... ou o que poderia, deveria melhorar?

6. (Rosa) Eu gosto de tudo, eu só não gosto de ficar aqui sentada o tempo todo, eu gosto da dinâmica. (...) Eu compreendo os alunos por que eu sou assim. (...)

7. (Safira) (...) Eu acho que sempre, por causa da própria disciplina, eu estava a par ou pelo menos preocupada com isto, mas sempre com um discurso mais vazio. Agora nos últimos 5 anos eu passei por uma série de experiências pessoais e estas experiências me fizeram buscar uma harmônia interior, uma busca espiritual maior, então esta busca espiritual maior fez justamente reforçar (???) buscar forças num pequeno jardim, buscar forças no diálogo com uma planta. Então este lado da minha vida veio reforçar alguma coisa que era mais vazio no discurso, então um pouquinho a mais que eu sei agora eu acho que é um pouquinho mais de sentimento no que faço.

8. Para eu participar de um compromisso de 120 horas depois de aposentar è justamente buscar (???). O lado ruim que estou sentindo, se é um curso que envolve os colegas durante meses eu acho que a coordenação deveria providenciar (...) eu já disse aqui (...) nome endereço e fone de contato. (...) para ligar num momento (???) e conversar: o que você está entendendo o que você está achando. agora quanto onde eu acho que vai chegar eu tenho a esperença que eu saia mais convicta, para transmitir um ensino mais formativo, em que eu possa sentir realmente o que eu estou fazendo, participando um pouco mais da vida do aluno (???) acho muita necessidade de interação, nós não podemos ter arestas com o outro na escola, que é o lado mais dificil (???) se nós temos dificuldade de relacionamento eu e seiscentos alunos muitas vezes pequenos grupos (???) faz um efeito mais forte. Agora a gente acredita que vai sair assim mais forte. (Observação o som original está muito ruim)

9. (Violeta) Como as colegas eu me sinto bem em estar neste barco, apesar de haver algumas tempestades. Eu concordo plenamente com a Safira, senti dificuldade de entrar em contato, por exemplo tive problema de falecimento na familia, mesmo diante da dificuldade eu tentei telefonar aqui na escola no sábado não consegui. (???) dificuldade de comunicação da gente da mesma cidade morando tão perto do local do curso, 


\section{APÊNDICE 12 - AVALIACÃO E EXPECTATIVAS SOBRE O CURSO FL.2 de 9}

então concordo com a Safira. (???) Pensar nos pontos falhos no caso talvez seja da minha parte, eu esperava mais,,, assim,,, sugestões, práticas.

10. A gente vem para um curso querendo resolver os problemas de imediato das questões do dia a dia da sala de aula, eu sei que a falha talvez seja minha, eu me coloco que esta esperança queremos resolver os problemas não a longo prazo mas querendo ver a solução, sabemos que a situação é bem critica, então queremos a solução do dia para a noite. Ao pensar ao refletir eu chego a esta conclusão, não é, foi um problema que levou vários anos para a gente enxergar essa situação tão crítica, então logicamente eu não posso esperar resolver do dia para a noite. Mas eu também sou impaciente apesar de aparentar calma, não é aquela calma, tem a ansiedade de resolver os problemas rapidamente, entâo é uma das frustrações que entrento é buscar paciência para poder esperar os efeitos do remédio, tenho esta dificuldade. (???) A nossa pontualidade, também eu assumo a minha parte, que não sou tão pontual quanto gostaria. (...) Eu tenho consciência dessa minha fraqueza, gostaria de ser mais pontual. (...) Sobre estes pontos criticos, acredito que não são impedimentos para que a gente tenha um final de curso bom, realmente os pontos positivos superam os negativos.

11. (Carneiro) (...) Está me servindo como um modelo. Na realidade é o primeiro curso que eu estou fazendo nesta delegacia, nesta coordenação, e fiz pela insistência de duas colegas que me pegaram no pé . Por que? Porquê p'ra mim principalmente sinto muita dificuldade de sair de Sorocaba para ir para São Roque ou para outros lugares, (???) eu creio que deveria ser feito como está sendo feito aqui: ir para onde tem mais professores. Agora em relação ao curso em si, como eu estava falando, estou num patamar aqui, um dos pontos que a gente veio, (...) é realmente p'ra mim ter noção, ter idéia de: como eu vou usar o que eu tô aprendendo aqui, dentro da sala de aula, técnicas de sala de aula, sabe? As possibilidades que realmente eu tenha condições de usar os materiais todos deste curso.

12. O segundo ponto aqui, desse curso p'ra gente aqui, nessas questõezinhas que a gente vai p'ra casa, faz as liçõezinhas, né? Liçõezinhas no sentido de carinhoso, não de diminutivo aqui né? Ela deveria de ser assim, exposta sabe? Eu acho que o professor vem aqui, entrega na mão do professor, e a gente.., a idéia que eu tenho desse texto aqui ó, eu não sei qual que foi a idéia da minha colega, dela, dela, dela.. Eu acho que,,, quando você tem isso, antes de entrar ao texto Cecil da aula, que cada um..., mas dentro de um limite razoável um, dois minutinhos desse uma pinceladinha, dentro do que fez do texto p'ra ver se tá em concordância entre um e outro, se não tava, que a gente.: "Olha, então por que não é isso, por que é aquilo, né?".

13. Enessa parte ai de pontos positivos... nada mais do que, "Eu estou conseguindo novamente reafirmar, dentro de mim, o que eu sempre li, que é lutar pela preservação do meio", sabe? Isso já faço mais de doze anos, doze a treze anos. E a gente fala, faz e vê, sempre tá acontecendo o contrário do que pregamos por ai né? Então a gente fala que na vida da gente a gente não vai conseguir. Mas as vezes depois a gente vem aqui, como você tá falando, e não tá só eu não, temos mais quinze pessoas aqui, não é certo? Fora eu aqui nesse mesmo pensamento. Então a gente vê ainda que ainda temos possibilidade, de fazer o ser humano caminhar segundo aqui, usufruindo do mundo e não desgastando, e que os meus, os seus, futuro,... futuro no sentido de humanidade, ele vai poder ainda receber, que esse mundo vai servir p'ra subir na árvore, p ra fazer a balança, p'ra pular no rio, mergulhar, apesar da mãe dá bronca lá né? Apesar de que hoje nós, "Não tira o sapato, não pise na terra!", né?

14. A gente é nesse patamar, eu acho que p'ra mim está sendo válido, porquê o cansaço que a gente estava tendo de estar nesta batalha, achando dificil de eu falar, não só em escola, mas falar em conversa de amigo em barzinho, em coisa, "Oh, o negócio é o..., sabe? A gente tá vendo que tem outras pessoas também, divulgando. E que,, então a gente tem possibilidade ainda de reveter várias coisas ainda. E que a gente não deve ficar só nesse patamar ainda, deve também começar a agir sabe? Cobrar dos que tâo ai devastando. 


\section{APÊNDICE 12 - AVALIACĀo E EXPECTATIVAS SOBRE O CURSO FL.3 de 9}

Que nem a gente tava comentando aqui, o esgoto sendo jogado numa rua ai que tem criação de animais aqui. Então é isso que a gente já tem que começar a agir sabe? E a gente tem que começar com os nossos alunos, e fazer passeata mesmo e começar a cobrar a preservação, sabe? Esse é o meu patamar, e o meu pontinho continua aqui ainda porque eu quero aprender mais. Tô passando agora aí...

15. (Rosalina) Então eu penso que esse curso que estamos fazendo, é uno, é uma semente a mais das poucas, ainda, que estão sendo lançadas no sistema do ensino de hoje. E, essa semente a mais, ela deve ter, né? Coisas positivas, para que venham a combater toda essa complexidade do mundo químico de hoje, que afeta principalmente o ser humano e o sistema como um tudo. Então, para que isso aconteça, e que tenha um resultado positivo, há necessidade que todos participem, de uma forma assim, consciente e responsável, porque é uma coisa séria, é uma coisa necessária, né?. Não só o grupo, os demais grupos que desenvolvem outros tipos de projetos, em outras regiões, em outras partes do mundo, mas também devemos agir de forma positiva e procurar semear também, a outras pessoas, a outras regiões, p'ra que ela seja duradoura e transmitida de geração em geração, e que venha a trazer ao decorrer do tempo, só coisas positivas, envolvendo a tudo e a todos.

16. E dessa forma, é que nós hoje, certamente, é com estas práticas com estes cursos, que nós poderemos legar às geraçōes presentes ou futuras, algo de bom, algo de positivo, de uma vivência bem melhor desse nosso mundo maravilhoso, e que nós, enxergamos com os nossos olhos, essa maravilha, né? Eque cabe somente a nós, né? Tudo isso, tudo isto que nós falamos, a nós e ao nosso próximo. A parte ai que fala de pontos negativos, o problema é que a gente não tem assim, um tempo disponivel que deveríamos ter para resolvermos todos os problemas para dedicar mesmo a um projeto tão importante para nossa vida, então eu acho essa parte falta de estímulo devido a nossas funções né? E que isso toma grande parte de nosso tempo e que estas coisas também importante eu vivo repetindo isso, mas mesmo assim, mesmo sendo utilizado de uma forma tão positiva como o curso, tudo isso já valeu.

17. (Jade) Eu acho que o curso está sendo bom eu acho que eu estou crescendo individualmente. (...) Essas visitas aí, nas hortas, é uma coisa inédita na minha vida, eu sempre tive vontade de conhecer, né? E ainda mais esse trabalho alternativo, a fita me chocou. Tipo uma terapia né? Acho que a gente ouve coisas que a gente nunca imagina que vai ouvir, a gente vai se surpreendendo com as pessoas. (...) falam coisas bastante interessantes, bem sensiveis, as pessoas do grupo. Só que eu tô encontrando dificuldade de tempo também p'ra me dedicar de fato ao projeto né? Como colocar em prática alguma coisa assim a nivel coletivo né? Que pudesse abranger os alunos mesmo. Que p'ra mim eu sei que está sendo bom. Eu estou mais atenta assim ao meio ambiente, mais sensivel a problemática da natureza, na televisão quando a gente vê alguma noticia, a gente, "Olha!". A gente fala assim, "Olha o que tá acontecendo. Olha aqui...". A gente ficou mais atenta a essa problemática do meio ambiente.

18. Mas eu tenho dificuldade na prática de aplicar assim, até a parte de técnica de conteúdo. Para eu passar assim, se eu fosse passar uma parte teórica com os alunos, uma parte de conteúdo, eu sinto dificuldade também de passar essa parte aí, não só na prática quanto na parte térica. (...) 0 projeto mesmo não tem é falha nossa e não do Antonio Vitor né? É falha nossa não, é falha minha de ter né?, de refletir, de pensar no projeto. Você já passou a técnica para a gente, assim de como montar um projeto. Assim: os objetivos, a justificativa, né?

19. Agora p'ra mim, segunda feira, estava vendo a entrevista do Décio Pereira no Roda Viva, não sei se alguém assistiu, ele falou um pedacinho da soja transgênica, houve bastante polêmica sobre este assunto ai, inclusive o Ministro do Meio Ambiente não queria, não queria liberar a soja transgênica. E deu p ra chegar a conclusão que mesmo os cientistas estando contra, vai ser boa, vai ser ruim, as decisões no fim são tomadas 
APÊNDICE 12 - AVALIACÃO E EXPECTATIVAS SOBRE O CURSO FL.4 de 9

politicamente, não tem (...), eles tomam decisão no final, não é o que achou que vai ser melhor, ou que não vai ser melhor, ou a ciência social, ou a ciência politica, ou a ciência biológica, ou as ciências físicas, mesmo vendo o que é bom ou o que é ruim pro mundo, mas as decisões são tomadas politicamente né? Como (...), um grande número de deputados, que estão por aí. Então, p'ra mim eu fico frustrada com essas coisas, a gente sonha, a gente tem vontade de mudar. Não é por causa disso que a gente vai desistir de fazer a nossa parte né? Mas tem vez que: né?

20. Ao mesmo tempo também tem noticias na televisão né? Que tem pessoas trabalhando com sucata, com reciclagem. No Brasil, ontem mesmo eu vi, é dos paises que mais aproveita as latinha de cerveja, latinha de coca-cola, toda essa parte de latinha, pelo menos nessa parte o Brasil está em primeiro lugar de reaproveitar né? Também tem o lado bom que vem e faz o contrário também né? Acho que tá faltando mais é da minha parte né, de tempo p'ra refletir, p'ra estudar mais, de conteúdo também falta de técnicas, tanto teórico como práticas: Como passar isso para os alunos? Mas acho que de uma maneira geral foi muito bom o curso.

21. (Vitor) Só para situar um pouco a Cida: a Jade é de educação fisica.

22. (Cida) É, eu sei.

23. (Jade) Eu passo vídeo para os alunos, parte teórica também eu passo (...) A gente tem uma certa liberdade, caminhadas. (???) fazer uma horta por exemplo seria até acessivel, talvez mais flexivel que outras matérias, matemática por exemplo, mas eu não sinto, não tá sabendo como passar.

24. (Floripedes) Bem, como todos os colegas já falaram né? O curso tá sendo ótimo. No meu caso, p'ra mim tá sendo um elemento a mais, na minha bagagem cultural, (???) uma troca de experiências, relatos do que cada um faz. É o que pesa mais. É que o meu pensamento é o mesmo que, vejam bem, o que eu vou falar praticamente todo mundo já falou. Então, vai mais ou menos pelo mêsmo caminho. Como interagir? Como o nosso colega já falou também, precisa ter tempo, mas o espaçozinho que tem a gente procura partir p'ra uma pesquisa, tem que estar atenta ao assunto, né? E, nesse curso aqui, como todo mundo está pretendendo: quer-se técnicas p'ra gente aplicar com os alunos, mas é claro, o que a Cida sempre fala, 'Nada vocês vão encontrar prontinho, vocês é que vão tentar descobrir e coisa e tal.' Então, através dessas trocas de experiências é que a gente vai aprendendo, e vai aplicando, vai conseguindo aprender uma técnica a mais p'ra poder passar isso para os alunos. Isso que eu tô falando que é o elemento a mais no trabalho, na minha bagagem cultural, né?.

25. E creio eu que agora no segundo módulo, que o assunto: o ambiente, né? Eu acho que aí é que a gente vai conseguir né, essas técnicas. Porque no primeiro módulo ali foi mais uma introdução do que seria o nosso curso, né? Vê que cada um contou a histórinha que também é gostoso de se ouvir. Então eu acho que daqui p'ra frente, pelo próprio tema, vai fazer com que a gente já crie, tenha idéias assim de como trabalhar isso com as crianças, por que o ponto fundamental ai é o empenho de nossos alunos, né? Eu acho que a partir deles, é que nós podemos aumentar esse nosso grupo. Nós estamos aqui num grupo pequeno, é como a professora falou, tentar espalhar a sementinha, né? E cada lugar que vá a sementinha a gente vá com novos e novos elementos p'ra conseguir, multiplicar essa conscientização. O que é o ponto fundamental é conscientizar o ser humano da importância do nosso meio ambiente, tá? E a parte negativa é a falta de tempo, mas nós temos que encontrar o tempo sim, p'ra poder, né? Levar em frente o nosso trabalho, tá? Demais coisas p'ra mim tá tudo bem.

26. (lara) Bom, eu também vim fazer este curso bastante ansiosa, bastante expectativas. Porque depois de algum tempo que a gente para de acreditar, né? Na escola, na faculdade. A gente vai se tomando alienado e vai ficando desestimulado, né? E achando que não vai encontrar a solução para os problemas. Então fica 


\section{APENNDICE 12 - AVALIACÃO E EXPECTATIVAS SOBRE O CURSO FL. 5 de 9}

bastante dificil. E geralmente é muito dificil nós termos um curso como esse. Nós termos acesso a um curso. Então eu vejo assim uma oportunidade p'ra eu, encontrar subsidios, p'ra crescer profissionalmente, para acrescentar um pouco mais. E também p'ra preencher um outro lado né! que é o lado espiritual como a Safira já falou. Então eu achei que, eu estava necessitada naquele momento, eu também estava necessitada, não só em buscar aqueles subsidios profissional. Mas também subsidios p'ra eu sentir um pouco melhor espiritualmente. No curso até o presente momento, eu encontrei, tenho encontrado, principalmente aqui, através desses nossos encontros que eu tenho achado tão interessantes, que a medida que cada um de nós vai expondo, mesmo que seja uma coisa mínima, uma experiência mínima, às vezes é o suficiente p'ra gente, se sentir mais valonizado se sentir melhor.

27. Com relação a esse, a esse assunto do segundo módulo, eu também acho que agora, nós vamos entrar assim numa área mais, mais gostosa digamos assim. Porque agora nós vamos lidar com assuntos que estão diretamente relacionados nós e que nos diz respeito e que por falta de tempo ou por falta de material, não temos assim uma bagagem suficiente p'ra transmitir de forma consciente e responsável para os nossos alunos, que é esse o nosso objetivo. Então é aqui, com certeza nós vamos conseguir ter esses subsídios. E com relação aos pontos, contra ou negativos ai, são tantos os positivos que supera, os poucos negativos. No meu modo de ver, deveria ter explorado um pouco mais os videos, a questão dos relatórios, nossos relatónios que o Cameiro colocou. E também mais visitas, não ficarmos a maior parte do tempo aqui sentados né? Sairmos juntos. E eu estou muito contente de estar nesse barquinho, né? Já ajudou bastante profissional e espiritual.

28. (Lobo) ... Bom, acho que essa questão ambiental, acho que, tá tendo muito material, (...) esse tema não era tão abordado quanto é hoje, não tinha tanto material quanto tem hoje. (...) Principalmen-te de geografia e ciência, até dá uma confusão por que eles colocam tudo em ciências(...). Mas tá saindo bastante coisa realmente, tem uma série de livros aí, como essa série que o seu livro faz parte, né? Do meio ambiente. $E$ também tem de outros editores. Então tem sobre esse assunto tem muito material realmente né? Pra ser estudado, muito material p'ra gente ler. Eu sou uma pessoa que gosta muito desses temas todos, do meio ambiente, agricultura. Sempre gostei! Inclusive eu pretendo fazer alguma coisa nessa linhagem mesmo, mas futuramente, tá? Porque eu gosto mesmo dessa parte.

29. No meu ponto de vista vejo que a semente já está ai, só falta germinar realmente, Propagar o que a gente viu, conversando com o $G$, conversando com o João né? Essas coisas tão ai, tá iniciando. Eu acho que a semente tá ai, a gente tem que fazer isso ai se expandir, né? Prá que,,, realmente surta aí um efeito positivo e realmente a população em geral comece a reivindicar as coisas. É conscientizando que a própria sociedade vai começar a reivindicar, né? E muitas vezes, tá aí no nosso municipio né, a agricultura orgânica e muitas vezes a maior parte da população desconhece isso aí, sabe? Então, o nosso papel é fazer a sementinha, como todo mundo falou, já tá, né? A sementinha como todo mundo falou, tem que fazê-la produzir realmente e se expandir, p'ra tentar reverter todo esse processo que tá ai confinado. É lógico que tem a mídia contra. Tem os poderosos contra. Mas eu acho que a população tem mais força e poder que todo esse pessoal. É questão de conscientizar e lutar mesmo pelo que a gente pensa. Esse curso tá sendo muito interessante realmente, eu tô gostando muito. É gente acho que é isso ai, realmente tentar desenvolver o trabalho p'ra essa conscientização né?

30. É lógico que todo mundo falou da prática né? Mas eu acho que essa prática vai surgir a partir da oportunidade que nós vimos aí, na oficina também né? E essas práticas vão surgir aí também, p'ra gente desenvolver um melhor trabalho. É lógico que elas dependem individualmente e até do grupo da escola montar alguma coisa nesse sentido, mas eu acho que vai ser bastante interessante. $E$ os pontos negativos tô vendo poucos. Eu tô gostando de tudo porque eu adoro essa área, eu leio realmente sobre essa área, eu tô procurando as 


\section{APÊNDICE 12 - AVALIACĀo E EXPECTATIVAS SOBRE O CURSO FL.6 de 9}

coisas mais ainda agora depois que entrei, fazendo esse curso, tá? Prá mim está sendo excelente.

31. (Vitor) Então, o quê que tá faltando (...)

32. (Lobo) O que tá faltando é essa parte realmente que não tendo muita experiência, no meu caso, não tendo muita experiência, que nem essa coisa de trabalho de campo, né? Acho que foi muito válido esse trabalho de campo que a gente fez, eu fiquei lá junto perguntando, questionando um monte de coisas que eu não tinha feito ainda né? Então esse trabalho de campo que a gente não tem tanta experiência, acho que seria essencial que desenvolvesse mais esse trabalho de campo com a gente, p'ra gente poder também realizar junto com os alunos. Se a gente não tem experiência como é que vai fazer? Vai sair com os alunos e ficar fazendo o que né? Por isso trabalho de campo tem que ser mais desenvolvido para nós, porque na faculdade (???) a gente vê muito pouco, pelo menos na minha. Eu acho que é isso: estou gostando do barquinho, não pode deixar ele afundar.

33. (Amélia) Como os colegas já colocaram o barco, curso, está assim bem direcionado, eu acho que a gente precisa de subsídios, também na minha área eu acho mais complicado, eu estou com mais aula de matemática do que ciência e eu não sei como colocar isto, então a gente precisa mesmo desta prática. (...) Pontos positivos são: acho que tudo que a gente fez até agora, porque eu cresci como pessoa, eu ainda faço faculdade e a gente está sempre estressado e na faculdade e as aulas, e na faculdade a gente não tem, a gente tem muita teoria, teoria e prática é quase nada. Então a gente precisa realmente destes cursos p'ra poder ter noção de trabalho de campo para a vida mais direcionada para os alunos.

34. Ponto negativo eu também não consigo ver, gosto muito desta parte, desde criança eu sou chatinha vivia brigan-do: não mata passarinho. Eu era chata na visão deles, quer dizer eu não acho que isso seja ser chata, eu faço isso com a minha filha até hoje e graças a Deus eu acho que está dando certo, pelo menos com ela, já é um ponto positivo para nós. Eu entendo assim como trabalho de formiguinha todos nós aqui está caminhando para poder fazer uma exclamação da sociedade entre aspas ai, que o ambiente precisa realmente de socorro. Se a gente não conseguir fazer isto, não sei tá ficando cada vez mais difícil, eu vejo perto da minha casa tinha um rio a gente brincava, nadava, agora é no máximo um regato está totalmente entupido. (...) $A$ gente não consegue mais, tem muitos lugares que estão acabados. Eu acho que depende da resgatar. Eu também acho que falta mais prática.

35. (Jasmim) Então eu, como minha irmã falou aqui, eu me sinto uma formiguinha (...) Porque até p'ra entrar na sala de aula, você tem falar porque muitos deles são agricultores (...). Mas que, eles falaram que a dificuldade maior para mudar é o poder econômico né? Plantar orgânico demora muito para crescer e tal. E, infelizmente como até o agricultor orgânico falou lá: economia né? Que ele mudou porque ele tava vendo que a terra dele também não tinha mais condição de plantar numa agricultura a base de quimicos, certo? Então, eu vejo essa dificuldade sabe? A prática é bem mais difícil né? (...) mas na hora de passar para os alunos, p'ra poucos que a gente passa, tem essa dificuldade.

36. Eu espero que os meus colegas que continuam na sala de aula queiram fazer até um trabalho melhor, tá? Porque as vezes a pessoa não tem muito contato mas, sabe?, tem a condição, tem o jeito de passar de maneira melhor. Então, os pontos negativos eu também quase não vejo. Porque eu tento fazer de certa maneira, confiar meu tempo né? As vezes eu fico até com palpitação no coração, porque eu tento ser sempre certinha, certinha, né? $E$, até p ra fazer faculdade eu tinha, agora não estou mais fazendo. faculdade. (..) Mas é o que a gente sente, sente que está estressado mas que quer continuar no barquinho.

37. (Vitor) É errado se estressar, você que sempre é certinha não pode cometer este erro (risos)

38. (Hortência) Olha pessoal eu vou ser sincera. eu vim para o curso por que eu acho que tava muito assim, 


\section{APÊNDICE 12 - AVALIACÃO E EXPECTATIVAS SOBRE O CURSO FL.7 de 9}

terminei a faculdade não fiz mais nada assim. 0 ano passado a gente ainda estava estudando para o concurso, foi muito bom porque eu vi que eu assim, muita coisa que eu vi no ano passado não tinha visto nada na faculdade. E este ano eu tava assim, "Ah, esse ano eu vou ficar na minha casa". Mas é porque eu estava precisando mesmo, sabe? (...) Eu vim mais porque estava sentindo falta de, assim, crescer profissionalmente. Agora, quanto ao tema é,,, a gente trabalha mais com as crianças, nós sempre trabalhamos o meio ambiente, é tentar conservar e tal. Só que, eu acho que p'ra mim foi assim muito importante. Está sendo muito importante. Porque eu não tinha essa educação ambiental em muitas partes. Assim: na prática eu acho que eu falava uma coisa e na realidade eu fazia outra, tá?

39. Já passei por uma situação dificil, né? Eu já assim,,, eu tive uma atitude que, na hora, eu não podia fazer outra coisa, e eu não vi outra solução, entende? Eu tive que fazer $\dot{e}_{,}$, assim, eu nem vou tocar no assunto por que sei lá, o que vocês vão achar, né? Não posso falar agora no momento por que é dificil p'ra mim. Mas, eu tive que tomar uma atitude que na realidade foi assim, destruir a natureza certo? E não foi sozinha né? Foi com uma outra pessoa também. E teve assim, como se fala, consequências depois, tá? Na época eu critiquei quem me criticou. Tem um jornalzinho no meu condominio, né? No condominio que futuramente eu vou morar, e foi no jornalzinho que nós fomos criticados. $E_{y}$, nós fizemos até um texto, a gente, eu com meu noivo, criticando essa pessoa também, sabe? Poque falaram: "Ah, eles humilharam vocês! Eles fizeram isso..., outras pessoas que vieram falar com a gente e que também tomaram atitudes como nós, entendeu? Então, eles falaram, "Olha, vocês deviam colocar no jornal, que vocês não tinham outra solução". Nós montamos o texto e não sei porque foi passando muito tempo, ai nós não colocamos no jomal, e hoje eu falei: "Que bom que nós não colocamos, por que agora, eu fazendo o curso, ia ter vergonha de ter colocado no jornal", você entendeu? Porque assim, como pode né? E mudei ! Agora eu vou lá, nós vamos morar no Jaú, não sei se vocês conhecem. Então lá tem assim, tem bichos que eu nunca tinha visto, entendeu? Porque eu sempre morei na cidade né? Eu vejo de outra forma porque eu digo nossa eu quero reverter (???) isto ai. (...) Outro dia que nós estávamos comentando isto aqui, que a pessoa vem de São Parreira por que ela quer a natureza, mas ela muda do jeito que ela quer, e eu acabei fazendo isso também no lugar que eu vou morar, eu tentei mudar, entendeu? E não foi legal.

40. Eu acho, agora eu já vejo de outra maneira. Então eu via que eu falava certas coisas para as crianças mas eu tomava atitudes diferentes. Então p'ra mim foi, está sendo uma educação, nunca fui assim muito ligada a esse tipo de agricultura, eu vim p'ra ver como era o curso, tanto é que no primeiro dia eu fiquei: "Será que eu vou ficar? Será que vai ser bom p'ra mim? Será?... Acho que não tem nada a ver com a minha área: matemática", entendeu? Então eu falei, "Acho que eu não vou ficar no curso", mas no fim tá sendo ótimo, nossa! Eu estou toda a semana achando que tem que ler, tem que.,,, né? Prá mim está sendo muito bom. O que eu tenho maior dificuldade é de redigir alguma coisa, tá? A primeira vez que você falou vocês vão me trazer um resumo, p'ra mim, nossa, falei, "Acho que eu vou sair do curso". Mas agora eu tô vendo que está sendo ótimo p'ra

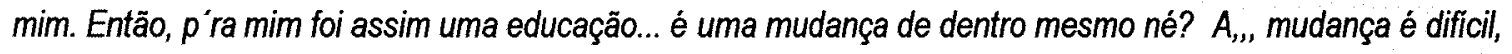
ainda tenho que mudar mais ainda eu acho, né?

41. Mas, só a experiência que eu passei, né? A experiência que eu passei, eu falei, "Nossa, se eu contar, aqui, logo no começo, ele vai me tirar do curso" (risos), eu comentei até com alguém: "Ele vai me tirar", (...). Ele já também (comentánios sobre o noivo) (...) Ele sempre gostou de mato,., esse João Dias ai é primo da mãe dele, ele conhece. Então tudo assim de eu falar: "Você já ouviu falar de tal coisa de agricultura?" Ele conhece, entendeu? Ele é muito ligado a isso. Então é,,, assim, quanto a nós dois tá sendo muito bom que eu tô passando p'ra ele. Agora, eu queria também, assim, é o ponto negativo que eu vejo, que eu queria saber, como que o curso poderia trabalhar na minha área, de matemática né? Agora, quanto às crianças, eu acho que é 


\section{APENNDICE 12 - AVALIACÃO EXPECTATIVAS SOBRE O CURSO FL. 8 de 9}

mais fácil, né? Na pré-escola você tem bastante bagagem assim, dá p'ra trabalhar num projeto legal. Agora, na, na matemática que eu não sei né? Isso ai que eu também gostaria de saber. Mas assim p'ra mim foi uma educação assim pessoal mesmo, né? Tá sendo bom, tá?

42. (Flora) Olha eu acho que esse tipo de dinâmica, de tá passando o barco, de tá comentando, eu acho assim super interessante. E uma outra coisa, é muito bom essa troca de experiência, acho necessário essa troca de experiência por que às vezes a gente quase não tem, essa, é, esse curso assim com outros colegas né? É acrescenta muita coisa, acho muito importante. Uma coisa que eu tenho assim comigo e gosto muito de trabalhar com educação ambiental, sou apaixonada pela educação ambiental. E outra coisa, é interessante porque nós fizemos uma excursão lá pará feira do livro, e eu acabei gastando um dinheirão, em coisas voltadas ao meio ambiente, e trouxe para os alunos, e nós trabalhamos a ISO 14000 dentro da sala de aula. É interessante porque quando você vê um aluno, de quinta, sexta série, lendo uma revista, que fala sobre uma Ceci, de um controle de qualidade da ISO 14000, eles começam a ficar assim, "Existe isso Dona Flora?", "Existe!".

43. Então é um despertar diferente. Uma outra coisa que eu acho assim, é como Safira colocou, depois de uma certa idade, (risos) não, mais é, é, incrivel isso gente, eu parei p’ra pensar, sabe por quê ? (..) Porque eu peguei quinta e sexta série este ano, e um dos alunos me chamou de vó, ai eu peguei, verdade, mas foi engraçado, não me chocou aquilo. Eu olhei pro menino né? Quinta série né? Poderia ter um neto daqueles lá na quinta série se uma das minhas filhas tivesse casado mais cedo. Ai fiquei pensando, falei, "Meu Deus, tanta coisa aconteceu comigo, mas tanta provação, mas tanta coisa, e de repente eu me vejo dentro de uma sala de aula, com um aluno me chamando de avó né?", - "O vó?", mas no bom sentido que ele realmente falou p'ra mim, "É que eu fiz confusão com a minha avón. Então existe uma troca, e aquilo fez bem, me fez bem sim, por quê? Porque eu, eu pensei assim, é uma maneira carinhosa de você tá podendo até passar pro seu aluno alguma coisa, por que ele vai até aceitar o que eu passo, existe muito respeito, eu adoro, adoro a $5^{a}$ e $6^{\text {a }}$ série, gosto dos meus alunos, assim no sentido de ter essa troca, eles falam bastante, eles são agitados, existe os que são..., mais existe uma afinidade muito grande. Eu tenho o maior respeito pela minha sala, $e$ faço que eles tenham,

44. É minha sala ambiente, né? A Ema sabe disso. Então eu tenho assim vontade de pendurar lá até nem sei um.. Até ontem colocaram uns passarinhos assim de origami, e a Ema foi ver, e ela, "Deixa ..." Sabe? Fazer com que o ambiente se torne agradável, é uma sintonia, (...) é muito harmonioso. Quando Safira colocou esse negócio de refletir. Olha, tirando as minhas atoladas lă, que eu tive dificuldade, que eu fiquei de pé lá na poça d'água (risos), vocês riem mas ele tá de prova, mas ai o José Francisco né? É vamos falar a verdade, existe uma, uma troca de ajuda, por que o quê que ele fez? Ele viu que eu tava me atolando, e veja bem, essa aqui fugiu (apontando para a colega Ema) e ele deu a mão p'ra mim. Eu senti na hora assim, sabe? Meu Deus, eu to perdida, ...

45. (Ema) Mas seu eu fosse ajudar ficava também.

46. (Flora) Ficava as duas. Mas então oh, isso eu até tenho que agradecer porque ele também se atolou depois e foi embora todo atolado. Agora, olha, é p'ra mim está sendo é,,. a coisa mais assim - é tá sendo gratificante. Uma coisa que eu achei assim, que já tinha, que eu já conhecia né? Que eu já tinha visto, faz com que a gente refita muito. E outra coisa, é engraçado, depois de uma certa idade, é estranho mesmo mas a gente para, e começa a pensar, depois que os filhos crescem, começam a,., De uma maneira bem diferente, começa a querer que o seu lado espiritual fique melhor, você tem mais sensibilidade. Então você olha p'ra natureza de uma maneira diferente. $E$ vendo na escola, um dia aquele livro, aquele livrinho de ecologia, que eu tava querendo fazer um trabalho p'ra eles, eu encontrei aquela carta do cacique Seatle, mandado para o 


\section{APÊNDICE 12 - AVALIACÃo E EXPECTATIVAS SOBRE O CURSO FL. 9 de 9}

presidente dos Estados Unidos, e trabalhei com eles na sala de aula, gente, se vocês vissem um aluno o que ele, o que ele falou, ele começou a perceber, nã, nem todos se interesFloram, porque já viu né? Não é mesmo todo mundo que se interessa. Mas o menino, Rafael disse: "Dona Flora, o indio gostava tanto da terra que ele não queria vender nem um pedacinho. Você veja bem o respeito que o indio tava tendo pela terra", e que tem né?

47. Então, é engraçado que eu fico assim numa ansiedade de querer passar uma porção de coisa, como ela falou, às vezes você chega, você fala assim, "Meu Deus do céu mas eu vou falar de agricultura, como é que eu falo? E tal". Até nós temos um trabalho que nós estamos desenvolvendo lá na escola, nós vamos precisar da sua ajuda, que é com a horta. Eu sempre..., a Safira vai me perdoar, não vai achar ruim: "eu senti inveja Safira do teu trabalho com horta e jardim com os alunos, eu nunca consegui na minha vida fazer esse tipo de trabalho e vou acho que morrer querendo plantar alguma coisa com eles. Porque eu sempre achei assim sabe? E nós estamos tentando desenvolver uma..., um trabalho lá. E sinceramente falando eu acho o curso aqui fora de série, sem demagogia, gosto de estar com outros colegas, aprendo muito, e tenho que agradecer de está aqui, de tá fazendo o curso, que nem todos tem essa oportunidade. E o ruim é a coisa lá de enfiar o pé lá na lama, eu acho que tem que emagrecer um pouco porque eu não consigo acompanhar a turma, eu e a Ema..., né? Mas tá sendo muito bom, muito obrigada por estar podendo passar isso p'ra gente.

48. (Ema) Bom, eu estou muito feliz nesse barco, contente mesmo. $E_{, y}$, sempre convivi assim com a natureza, eu amo demais a natureza por que eu sempre vivi em sítio, sempre morei em lugares assim afastados, não na cidade né? Agora que nós vendemos lá eu senti muito, acho até que eu comentei com você, e nós vamos morar na cidade, acho que p'ra mim acabou um pouquinho sabe? O meu coração, entendeu? Por que eu amava aquilo, mas, por questão assim de familia a gente teve que decidir e acabar vendendo. A minha vida foi sempre assim em contato com a natureza, nunca em cidade, eu só vinha p'ra cidade mesmo dar aula. Então todos esses conhecimentos que eu tinha, era assim de viver constantemente de tá ali na natureza. $\mathrm{A}$ gente tinha o conhecimento né de que é agravante essa história dos produtos químicos, mas não tinha assim uma noção, um aprofundamento melhor, né?

49. Então através desse curso, veio reforçar ainda mais, a minha visão, certo? Agora, o ponto negativo, $\dot{e}_{,,}$, sobre a minha falha de ser pontual né? Mas hoje eu cheguei cedo viu? Ela sabe. Que eu sempre sofro com a Flora né? No caso é só o que eu tinha que falar mesmo. Ah, e outro ponto negativo meu, é de eu não ter entregue o relatório, essa é a minha falha. (Vitor comenta sobre os relatórios) Nesse tempo que eu fiquei assim muito atarefada, na venda, na escritura, vai p'ra cá, vai p'ra lá, quase nem aparecia mesmo na escola, né? Então eu tive que tirar licença. Deu muito tumulto, muita coisa. É só.

50. (Safira) Agora o barco vai para o Antonio Vitor.

51. (Mulher-???) Agora eu quero ver (???).

52. (Vitor) A primeira coisa é que a gente tem que transformar este barco numa jangada, numa jangada cearense mesmo que são vários pauzinhos, na qual todo mundo esteja pondo os seus pauzinhos para fazer que ela flutue mais fácil, tenha maior estabilidade, que ela seja mais potente. A idéia é juntarmos os nossos pauzinhos (...) e acho que foi super bom o passeio de barquinho, ou reffetimos.

53. (Vitor faz algumas considerações sobre a dinâmica do "barquinho" e sobre alguns tópicos levantados na avaliação em especial quanto à prática.)

(FIM DA ATIVIDADE) 
APENDICE 13 - CONSTRUINDO NOSSO TEXTO COLETIVO SOBRE EDUCACCÃO AMBIENTAL

Após discussões em grupos e com o conjunto da turma, estimulados por leituras prévias e influenciados por suas formações profissionais e pelas experiências pessoais, os cursistas montaram o quadro abaixo. Composto por fichas confeccionadas pelos grupos, o quadro procurava apontar os principais elementos da educação ambiental.

\section{EDUCAÇÃO AMBIENTAL}

Conhecimento do meio ambiente.

Desenvolver uma consciência cidadã.

¿Promover o respeito ao meio ambiente

Atuação do professor: formativa.

Consciência ética.
A escola como uma instituição formativa e não informativa, com um envolvimento global, agindo localmente.

Harmonia do homem com o "ambiente".

Formação da cidadania que envolve mudanças de valores, de comportamento e de atitudes

Uma nova perspectiva de ensino que liga o "espaço escolar" ao "espaço de vida".

A partir das explanações dos participantes no decorrer do debate, outros aspectos apontados como importantes na educação ambiental foram destacados e registrados em novas fichas:

Considerar o emocional, o sentir, a motivação e especialmente as necessidades.

Postura coerente do educador
Considerar a dinâmica das pessoas (educandose educadores) e as suas histórias de vida.

Procurando organizar as fichas, sintetizar as discussões e agregar alguns aspectos que considera indispensáveis na educação ambiental, o coordenador produziu o texto a seguir :

\section{NOSSAS CONSIDERACÕES SOBRE EDUCACÃO AMBIENTAL VERSÃO PRELIMINAR PARA DISCUSSÕES E COMPLEMENTACÕES}

Educação ambiental é um processo educativo que visa promover o respeito e a harmonia dos seres humanos entre sí e com o "ambiente" através do incentivo à ampliação do conheci-mento e ao desenvolvimento de uma consciência ética e cidadã.

Reconhecendo que trabalhar a informação é importante mas que não basta, os educa-dores ambientais procuram influenciar na formação de habilidades e principalmente em mudan-ças de valores, de comportamentos e de atitudes. Para que o processo educativo tenha maior possibilidade de sucesso, é importante considerar a história de vida e a dinâmica das pessoas envolvidas (educandos e educa-dores). Levando-se em conta que os indivíduos são submetidos a dimensões subjetivas (emoções, sentimentos, motivação, desejos, etc.), pressões sociais e principalmente necessidades (biológicas, materiais, sociais, afetivas, espirituais e outras).

A educação ambiental defende que a escola precisa atuar como uma instituição forma-tiva e não somente informativa. Numa perspectiva de ensino que liga o "espaço escolar" ao "espaço de vida" propondo envolver os educandos e suas comunidades no enfrentamento das questóes ambientais a partir de açōes locais articuladas a uma perspectiva global. Nesse contexto o professor tem um papel fundamental e precisa apresentar uma postura coerente.

Observação: No quadro acima os textos em negrito foram retirados das fichas e os textos sublinhados foram propostos pelo Coordenador/Pesquisador para reflexão e futuras discussões. 
APENNDICE 14 - CONSIDERACOOES QUANTO A DISCUSSŌES ENVOLVENDO A EDUCACĀO AMBIENTAL FL 1 de 2

COMENTÁRIOSE TRANSCRIÇÕES DE TRECHOS DE FITA CASSETE / $9^{\circ}$ ENCONTRO 03/07/1999

Visando relatar as impressões sobre os textos lidos e resenhados em casa (livros citados a seguir); possibilitar a troca de impressões, o confronto e a busca de consensos em relação ao tema; e acrescentar informações e reflexões sobre E.A.

Textos selecionados dos livros: Conceitos para se fazer educação ambiental (1997) e Em direção ao mundo da vida: interdisciplinaridade e educação ambiental (1998) ambos da Série Cadernos de Educação Ambiental, publicada pela Secretaria de Meio Ambiente do estado de São Parreira

Destacaram se as considerações sobre inter e transdisciplinaridade; as diferenças entre as dimensões: física, biológica e humana-social; as propostas de projetos ambientais; relação entre verdade científica e incerteza; outras formas de saberes e a sacralização.

Um dos momentos interessante, foi a articulação que os cursistas fizeram entre as leituras e a apresentação da Educadora $O$, conforme o trecho transcrito a seguir, independente da falta de sincrônia e até uma confusão entre os participantes na abordagem dos temas: mistica e holística:.

As considerações iniciaram-se quando uma cursista $(\mathrm{C} 1)$ destacou o tema da responsabilidade dos seres humanos e o trecho do livro que diz: "Para dar conta dessa responsabilidade precisamos desenvolver este atributo muito mal compreendido, porém facilmente reconhecido e expressado pela humanidade, como sabedoria, compaixão e amor ..." (Conceitos para se fazer educação ambiental, p.34). Na seqüência outra cursista (C2) comenta:

C2 -"Eu tinha achado a O meio mística, mas depois que eu vi este livro aqui, tudo que ela falava, amorosidade, respeito, ..."

Outros cursistas se expressam:

C3 -"Tem até um capitulo dos princípios da responsabilidade global que fala de holística".

C4 "Mas a O tem uma associação holística realmente".

C3 - -E, então a gente percebeu isto, que existe, mas que não é só ela, tem muitos outros que escrevem".

C2 -Será que este livro aqui é daquele grupo dela de místicos lá da USP, que ela falou".

C3 -A Escola do Futuro".

A manifestação "não é só ela, tem muitos outros" parece estar associada à percepção de que ela e mesmo os outros convidados apresentam um discurso "inovador" (ambientalista) que não é um delírio, nem um idealismo sonhador (como a princípio foi rotulado o produtor $\mathrm{G}$ ). 


\section{0}

APÊNDICE 14 - CONSIDERACÕES QUANTO A DISCUSSÕES ENVOLVENDO A EDUCACÃO AMBIENTAL FL 2 de 2

O fato de estar escrito consolida e valoriza a posição. Outro aspecto que valorizou enormemente a proposta ambientalista diante deste grupo foi o reconhecimento feito pelo grupo da coerência entre discurso e prática que os convidados apresentavam, ou como avaliou um cursista: "não é um discurso vazio". Neste sentido as contribuições dos convidados durante as oficinas foi além dos discursos e conteúdos e incluiram: posturas, procedimentos, filosofia de vida... Já as leituras propostas possibilitam o reconhecimento de que há outros "que escrevem" em sintonia com aquelas idéias e posturas dos convidados.

Outra passagem que demonstra o impacto dos textos sobre os participantes foi a fala de uma cursista, que geralmente se manifestava pouco durante as discussões de enfoque mais teórico:

C5 - "Eu achei legal no texto que ele fala: A gente não está preparado para mais que uma resposta".

Também foi significativa a explanação da prof ${ }^{a}$ Safira sobre seu entendimento do capitulo: Conhecimento e incerteza do livro Conceitos para se fazer educação ambiental:

"O que eu entendi é que, até o momento, o Homem valoriza demais a racionalidade, a inteligência e a tecnologia. Que embora esta verdade científica não seja completa o Homem a enfoca como sendo a verdade e a aplica imediatamente. O Homem está esquecendo o lado intuitivo, emocional que é outra metade que o Homem tem que resgatar, baseado no conhecimento de culturas mais primitivas. Então é: o racional equilibrar com o intuitivo e desta maneira hamonizar melhor o ambiente. A educação ambiental deve tratar este lado de que: toda verdade da ciência tem que ser trabalhado com muito cuidado porque é uma verdade numa visão. Esta mudança e aplicação tem que ser gradual e não pode, apenas em função do lucro, desprezar toda a biodiversidade e o fator ambiental."

Aqui destaca-se a capacidade de apropriação da cursista em relação ao texto original, algo incomum no âmbito do grupo enfocado. 

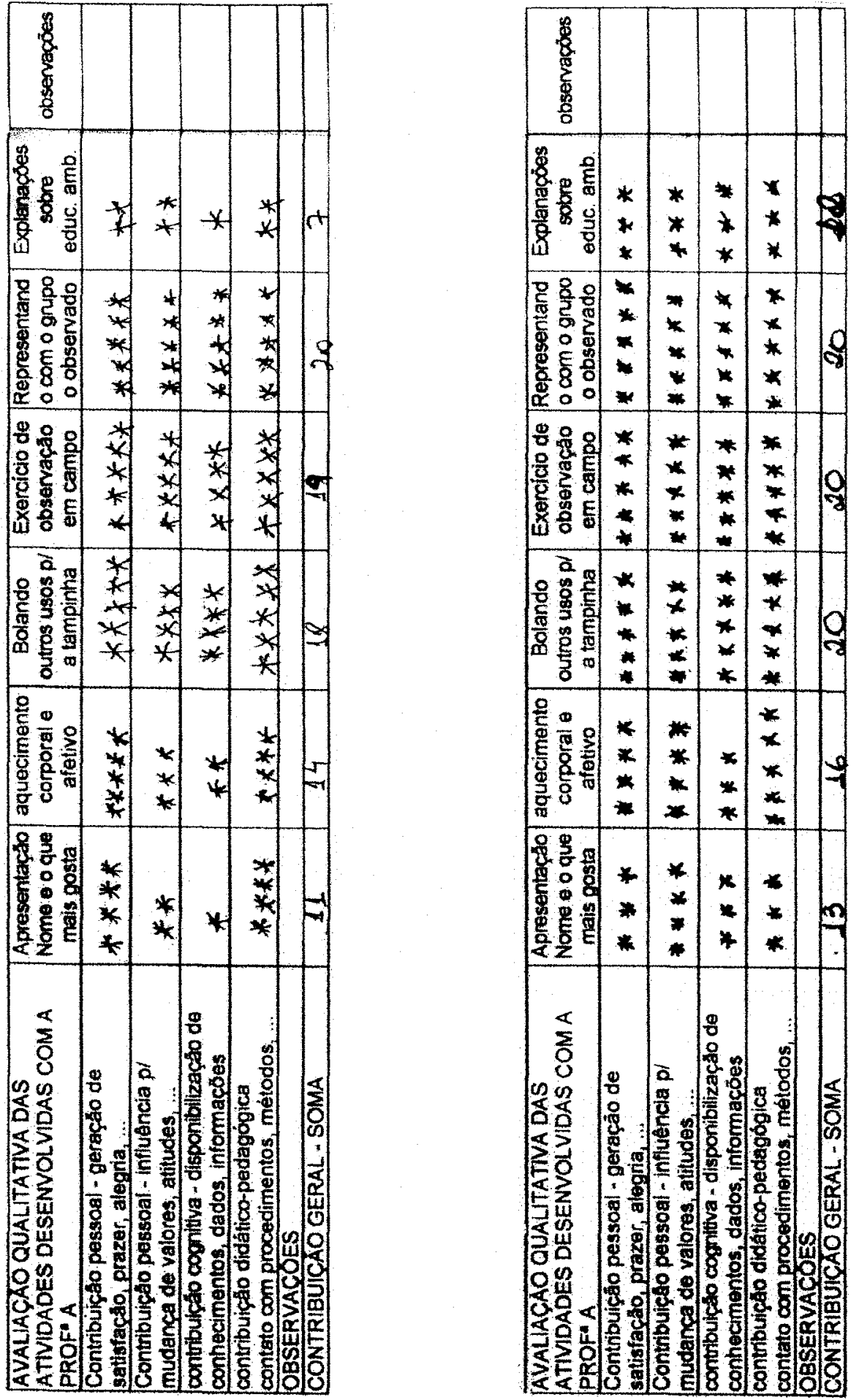
FL. 2 de 2

(ANOTAÇÕES NO VERSO)
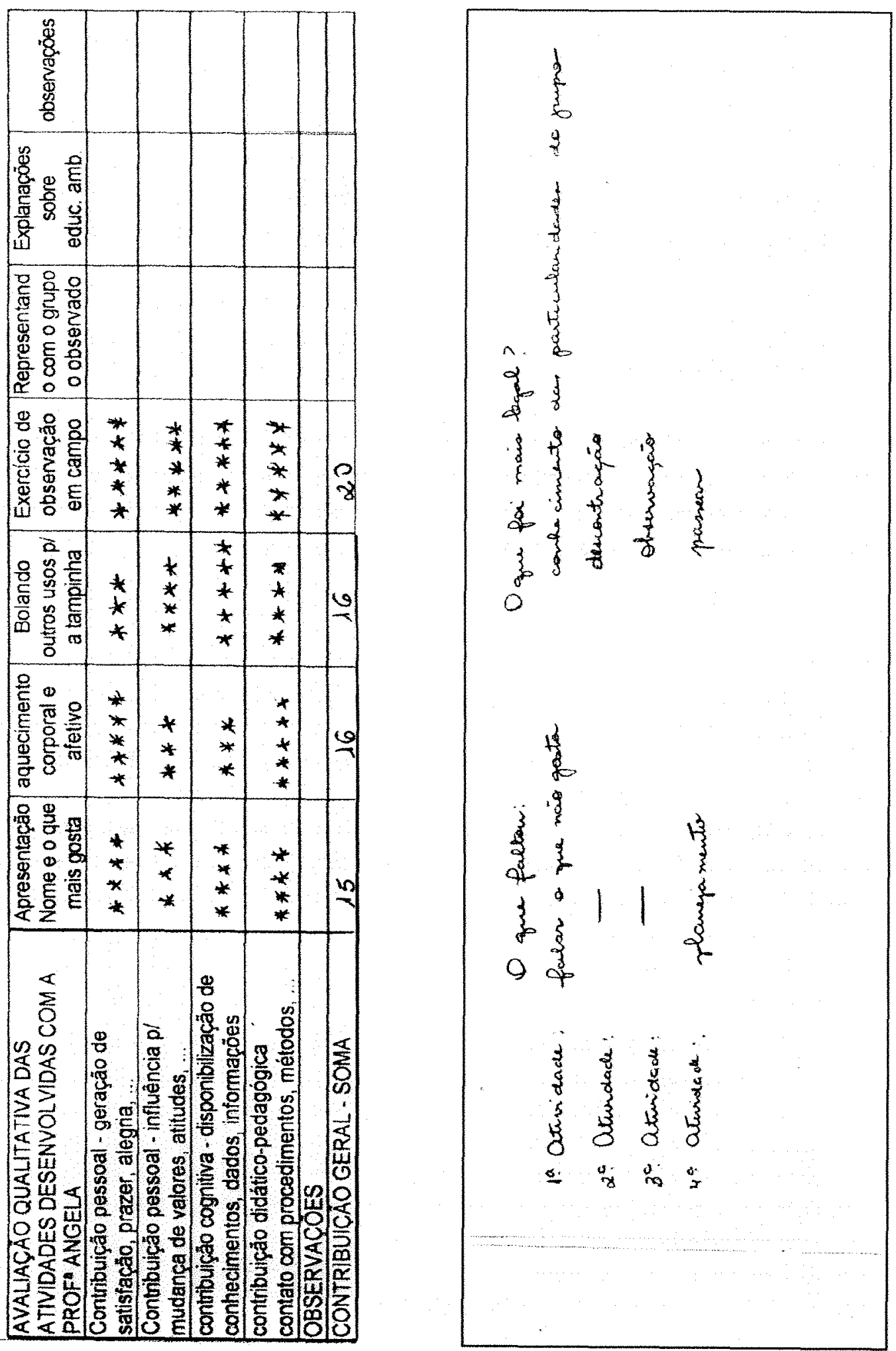
APÊNDICE 16 - Considerações SOBRE EDUCACÃo AMBientAL - PROF. MARCOS SORRENTINO - FL. 1 de 5.

\section{CONSIDERAÇÕES SOBRE EDUCAÇÃO AMBIENTAL - PROF. MARCOS SORRENTINO}

Texto adaptado por Antonio Vitor Rosa a partir de transcrição de fitas cassete $/ 8^{\circ}$ Encontro / 19/06/99

Eu começaria pela fala do professor, quando ele ressalta a questão da pessoa, de cada um ser um, de se trabalhar a partir da individualidade, considero isto fundamental em todo e qualquer processo de transformação social. Se refletirmos, é esta, a bastante, ambiciosa tarefa que nós nos colocamos uma grande transformação social. Afinal queremos transformar o planeta, queremos que 6 bilhões de habitantes se engajem e se envolvam num mesmo desafio, que é: a manutenção da vida, não só a sobrevivência da nossa espécie mas de todas as vidas que co-habitam esse planeta, entendendo por vida o próprio planeta Terra. Se, quando estudamos aprendemos que a Terra é o suporte para a vida, hoje mais do que nunca, vai se tornando claro que a Terra é uma unidade de vida, é como se fosse um corpo. Assim da mesma forma que quando apertamos o dedão e o corpo inteiro sofre, com a Terra ocorre o mesmo. Tudo que acontece em qualquer parte da Terra a afeta. Neste sentido em qualquer parte dela, manifesta-se a vida, então o vento, as correntes marinhas, as águas, tudo, são elementos de vida, com os quais co-habitamos o planeta, e que nós colocamos como desafio a sua manutenção, a sua sobrevivência, e especialmente a sobrevivência da nossa espécie.

Mas, mais que sobrevivência, nós queremos a participação da nossa espécie, queremos que todos os humanos participem. Entendendo participação não na concepção social democrática, de você a cada 4 anos ir a urna e depositar o seu voto, elegendo o menos ruim dos candidatos para te representar e ele entendendo que você assinou um cheque em branco para fazer tudo em seu nome. Não, a participação que nós queremos tem um conceito expandido, queremos tomar decisões, queremos nos sentir pertencentes, o nosso conceito de participação vai além de expressar a opinião: queremos dialogar sobre os problemas, queremos que todos os humanos (e até os não humanos) se sintam pertencentes para que eles se comprometam com as tomadas de decisões, para que se nós decidirmos: "vamos gastar menos água no municipio de lbiúna", todas as pessoas saibam: "vamos gastar menos água". E isso vire um compromisso cotidiano para cada um: "estou estabelecendo um pacto com todos os cidadãos e cidadãs desse município de gastarem menos água, porque a água é escassa no momento aqui no município", se vou escovar meus dentes, eu fecho a torneira enquanto escovo, se vou tomar banho e eu fecho o chuveiro enquanto ensabou-me, e fico menos tempo embaixo da áqua.

Só poderá haver essa participação nesse desafio da sobrevivência e da busca de emancipação e de autonomia se isso for um compromisso pessoal. O que seria então o nosso desafio maior?... É tratar cada pessoa como pessoa, fazendo emergir o sujeito e não a massa. No meu ponto de vista, todo tratamento em programas de educação ambiental deve partir desse pressuposto, de tratar as pessoas como pessoas, fazendo com que emerja o compromisso individual com o processo coletivo. Estas nossas preocupações devem estar presentes no processo coletivo de uma aula para aquisição de um determinado conhecimento, que nós consideramos ser importante para o educando ou grupo com o qual estamos trabalhando, na perspectiva de que esse conhecimento seja apropriado e transformado pelos indivíduos e grupos, tornando-se significativo e desafiador para o seu crescimento. Mas, para além disso, precisamos transformar cada espaço, cada momento em um desafio pessoal de mudança e transformação. 
APÉNDICE 16 - CONSIDERACÕES SOBRE EDUCACÃO AMBIENTAL - PROF. MARCOS SORRENTINO/FL. 2 de 5

Para iniciar gostaria de ressaltar essas palavrinhas que eu venho mencionando: participação, sobrevivência e emancipação. Eu falo de emancipação colada com a busca de autonomia, autonomia pessoal, autonomia do grupo, autonomia de uma sociedade, autonomia de uma espécie, autonomia na construção do meu projeto emancipatório, do nosso projeto emancipatório. Mas o que é o meu projeto emancipatório?... Ele é espiritual?... Ele é material?... Cada um tem o seu, mas me parece que é imbricado com o conceito de emancipação, a autonomia do delineamento do seu projeto emancipatório, no seu projeto individual, do pequeno coletivo, dos coletivos ampliados. Essas palavras não são gratuitas, não foram inventadas por mim, elas demarcam a história do movimento ambientalista e estão na sua gêneses. Assim quando tentamos analisar o que são os ambientalistas? Quando eles surgem? Como é que eles se manifestam em diferentes locais do planeta, com diferentes grupos sociais? Percebe-se que essas palavras são palavras-forças na aproximação e mobilização das pessoas em torno da temática ecológica/ambiental.

Creio que cada um de nós nos aproximamos da temática ecológica/ambiental, por uma porta de entrada diferente. Alguns de nós nos aproximamos pela preocupação com a alimentação, ou com uma doença, ou a partir da alimentação que está relacionada à doença ou com a forma de respirar, outros se aproximaram pela preocupação com os relacionamentos humanos, outros pela questão da tomada de decisões (essas modalidades de tomada de decisões não me agrada, essa modalidade de gestão do espaço público cotidiano não me agrada, votar a cada 4 anos, ou não haver a revogalidade de mandato, não haver voto distrital não me agrada).

Mas independente da porta de entrada que me aproximou da temática ecológica ou ambiental eu começo a ver que há um corpo de conhecimento, um corpo de intencionalidades que une pessoas na direção de um futuro. Há 2000 anos atrás, os cristãos eram jogados aos leões e continuavam professando a fé cristã, porque havia um corpo de convicções que os unia, da mesma forma hoje se expressa na humanidade uma convicção ligada a sobrevivência da nossa espécie, que não tem muita cor, não pode ser chamada de cristianismo ou de ecologismo ou qualquer coisa, mas tem muitas portas de entrada que nos permitem visualizar que nós queremos caminhar numa direção de futuro que parece ser comum a muitas outras pessoas. Apesar das agressões cotidianas que sofremos em nossa cidadania, esse sentimento difuso, de estar participando de um movimento humanitário, um movimento civilizatório num sentido ampliado, nos faz de alguma forma falar: "eu vou continuar tentando, eu vou separa o lixo em casa". Nesse sentido então esse compromisso, essa participação, não se expressa apenas em ir numa reunião ou se filiar a uma associação ambientalista, mas se expressa de diversas maneiras,

Eu acho que trabalhar com educação ambiental é um pouco pensar essas coisas. Nós como pessoas privilegiadas que têm acesso a uma série de informações inclusive a partir da literatura, que a grande maioria das pessoas não tem, podemos fazer essa viagem lógico/formal, (intelectual) no sentido do compreender o quê é esse processo de transformação humana no sentido de garantir a melhoria da qualidade de vida, a melhoria do meio ambiente, etc.

Fazemos essa viagem intelectual, mas ela não basta, Roland Barts que é um escritor, falava que em termos de amor, não basta a compreensão racional, pelo contrário, às vezes a compreensão 
APÊNDICE 16 - CONSIDERACÕES SOBRE EDUCACÃo AMBIENTAL - PROF. MARCOS SORRENTINO - FL 3 de 5.

racional é a forma de acabar com o amor e diz: "é melhor ser um jardineiro do que um botânico, em termos de amor o melhor è amar". Quando você decodifica o amor e tenta compreendê-lo racionalmente é provável que seja o início do fim da relação amorosa. No entanto para levarmos adiante a proposta de transformação, não podemos nos furtar à compreensão lógico/racional, pois a nossa sociedade exige esse discurso para validar as propostas de transformação. O desafio que está colo-cado para nós é enfrentar o paradoxo de ao mesmo tempo nos tornarmos botânico sem deixar de ser jardineiro. Ou seja, é continuarmos a ter uma aproximação em relação à vida e às questões da sobrevivência, mas sobrevivência com qualidade, enquanto direito a moradia, a água de qualidade, a alimentos de qualidade a educação, etc. $O$ desafio que está colocado para essa temática é: continuarmos a ter um aproximação afetiva (amorosa) e ao mesmo tempo, a partir da ciência, fazermos um discurso e uma apropriação lógico/racional (intelectual, compreensivo, etc.). Em outras palavras o que desejamos é fazer das ferramentas racionais e das ferramentas sentimentais, afetivas, subjetivas, ou seja das diferentes modalidades de apropriação desse objeto que é a vida, a nossa maior estratégia de educação ambiental e de transformação na direção do que almejamos.

Mas como fazer isso? Essa brincadeira das letras do nome é tão singela, mas no meu ponto de vista, expressa o desafio metodológico, o desafio técnico que devemos colocar para o cotidiano da nossa prática escolar, nossa prática enquanto educador ambiental, que é: como aproximar a emergência do sujeito e o compromisso planetário? Nós falamos de cidadania planetária, mas não existe um cidadão planetário no geral. Lembro-me que quando era estudante universitário, queriamos que os estudantes fizessem greve em solidariedade ao povo nicaragüense, contra a ditadura do Somoza, e os estudantes falavam: "vai passear", a grande maioria dos estudantes falavam: "nós queremos discutir a questão da alimentação aqui, a aula que está ruim e não solidariedade planetária". Agora falamos em solidariedade com Mico Leão Dourado, com a baleia, "meu vai para a casa, nós temos que encontrar a nossa casa, tenho que por comida para o meu filho se alimentar e você vêm falar em Mico Leão Dourado". E ai surge muito da polemica entre ambientalistas e as pessoas envolvidas com as causas sociais, lembro-me daquela música "troque o seu cachorro por uma criança pobre" do Eduardo Dusek, ou um cubano que eu conheci que bravo dizia mais ou menos assim: "educação ambiental é um luxo, em Cuba é possivel se fazer educação ambiental porque lá já está resolvido o problema de moradia, saúde, educação, agora é possivel fazer educação ambiental". Eu discordava dele dizendo: "mas a coisa não é linear", se envol-ver com a temática da sobrevivência no sentido expandido, ser solidário ao Mico Leão Dourado, não precisa ser somente depois de resolver os problemas de moradia, alimentação, as coisas andam juntas.

O Roberto Freire (escritor) fala: "em termos de amor, o amor não depende do objeto amado, o amor é uma qualidade do individuo, quem ama, não ama em função do objeto, mas ama enquanto predicado seu, e de tal forma você ama e você pode desenvolver a capacidade de amar, que você pode abrir mão do objeto"; deixa de ser um amor possessivo, deixa de ser um amor direcionado e passa a ser uma qualidade que você vai desenvolvendo em você próprio de forma que você passa amar a vida, amar tudo. Eu acho que é um pouco isso que a temática ecológica/ambiental coloca, não é abrir mão do compromisso com a alimentação, a moradia, as questões sociais mais cadentes, é entender que caminha-se junto na direção de ao mesmo tempo melhorar as condições de vida de nós humanos e garantir a 
APÊNDICE 16 - CONSIDERACÕES SOBRE EDUCACĀO AMBIENTAL - PROF. MARCOS SORRENTINO/FL. 4 de 5

sobrevivência de outras espécies, do Mico Leão Dourado, da baleia, etc. A pessoa não precisa pensar por etapas, isso não quer dizer que o dinheiro público não seja um só, não seja restrito e que não tenhamos que estabelecer prioridades.

Por exemplo: o dinheiro público é um só e temos 500 reais, eu vou aplicar num programa de conservação do Mico Leão Dourado ou num programa de construção de moradias? Nós vamos ter que administrar esse recurso e, eventualmente, nós vamos falar assim: "temos que dar moradia para as pessoas e o Mico Leão Dourado não vai receber nenhum tostão" e vai acabar enquanto espécie. Esse desafio é concreto, quando faço esse discurso de desenvolver a nossa capacidade de olhar para toda a diversidade e valorizá-la, não estou querendo me furtar das contradições quotidianas que exigem tomadas de decisões, mas esse processo de compromisso e engajamento vai nos possibilitando buscar soluções criativas, que consigam ao mesmo tempo dar moradia e conservar o Mico Leão Dourado. Acho que o dilema que está colocado para nós não é o do Eduardo Dusek, acho que no atual estágio de desenvolvimento da humanidade, é possivel encontrarmos soluções criativas que mantenham o cachorro e a criança pobre, agora como que isso vai ser possível? Não é com as soluções macros, é com a descentralização, é com o convite a cada pessoa a ser criativa na solução. Assim, se eu quiser, com 500 reais de dinheiro público resolver o problema das crianças e dos cachorros, eu provavelmente terei que optar por um ou por outro. Mas se eu devolver para a sociedade esse desafio e buscar soluções criativas junto com a sociedade, não no sentido de lavar as mãos, como temos vistos nos últimos governos: "É descentralização!, É terceirização!... etc. vocês resolvam", e ai ninguém tem dinheiro, não é isto que queremos. Defendemos políticas que fomentem respostas criativas. Ao invés de optar pelo recurso escasso, ele deve ser utilizado no sentido de fomentar politicas para que cada indivíduo, cada comunidade apareça enquanto sujeito e busque as soluções criativas que possam dar conta da criança pobre, da moradia, do cachorro, do Mico Leão, etc.

Em sintese eu queria iniciar essa nossa conversa no sentido de dizer que, o desafio que está colocado para nós, educadores e educadoras ambientais, é de tornar significativo esse desafio, essa temática ecológicolambiental para cada pessoa. Isso só acontecerá se buscarmos técnicas e métodos que possibilitem que a pessoa se veja enquanto pessoa e não enquanto massa. A pessoa perceba: "eu faço a diferença", "eu tenho um papel a desempenhar nesse processo". Nesse sentido a brincadeira anterior possibilita a cada um se perceber enquanto pessoa. Eu sempre digo: "trabalhar com nossos alunos sabendo o nomes deles é essencial" ai o professor fala: "é porque você dá aula para 2 ou 3 turmas, vai dar aula para 20 turmas com 40,50 alunos, você sai de uma, entra noutra, como é que vai saber os nomes?" É verdade, completamente verdadeiro e ai o desafio de transformar cada aluno em pessoa, não passa por essa técnica de chamar cada um pelo nome. É fácil com um grupo pequeno, mas acho que essa técnica pode ser fertilizada para outras situações.

Um dia desses uma aluna da minha disciplina chegou na sala de aula falando assim: "larguei a sala no meio da aula, ...eu não agüentava mais*. Ela era professora substituta e foi chamada para dar aula, a molecada botando fogo na sala e ela: "por favor, quietos!" Ela com todo idealismo pedagógico de não gritar sei lá o quê, ficou maluca e falou assim: "vocês não me querem então vou embora", saiu e foi embora. Imaginem o dilema que essa menina vivenciou ali naquele momento. Ela vai ter que en-contrar 
APÊNDICE 16 - CONSIDERAGÓES SOBRE EDUCAÇÃo AMBiENTAL - PROF. MARCOS SORRENTINO - FL. 5 de 5.

outras técnicas, suas técnicas. Vários professores encontram essas técnicas, às vezes só olhar no olho, às vezes só uma palavra mais atenciosa, faz com que o aluno se sinta sujeito, se sinta pessoa e tenha um envolvimento diferenciado. Têm professores que pegam o aluno mais rebelde, aquele que quer se fazer notar e pede para apagar o quadro, cada professor vai encontrando suas técnicas.

Quando discutimos educação ambiental se reivindica muita a apresentação de técnicas e sempre falamos, "não estamos aqui para apresentar técnicas, regras, não sei o quê", porque elas são pessoais, cada um tem a sua. 0 que é importante é termos um horizonte, 0 sentido para onde queremos caminhar e a partir dai encontrar as técnicas para fazer isso. E esta busca por as técnicas não deveria ser solitária. Mas é o que acaba acontecendo, do jeito que nós somos massacrados na busca pela sobrevivência, nós não temos mais oportunidades para encontrar interlocutores para nossos desafios os quais se tornam desafios individuais e passamos a viver a tragédia individualmente: "ah, eu não sou um bom professor, eu não sou um bom cidadão, eu não consigo fazer isso". Ultimamente tenho citado muito a tragédia do câncer que tem sido vivido individualmente, cada um de nós encontra uma tragédia familiar, uma tragédia individual. Mas está se tornando claro que o câncer não é apenas um problema pessoal ou uma tragédia familiar, só que não temos oportunidades de conversar sobre isso, são poucas as organizações, as associações de pessoas ou de familia de pessoas que tiveram câncer, nós fugimos disso mas precisamos parar para conversar e falarmos: por quê isso? Por quê dessa tragédia moderna? Onde estão as raizes desse problema e como que buscamos técnicas para enfrentar esse problema?. Para diminuir a incidência desse problema, aonde estão as causas desse problema?" Esse é um exemplo extremo mas é, da mesma forma, desafios que são colocados quotidianamente para nós, e que não arrumamos tempo para discuti-los porque nós somos oprimidos pela necessidade da sobrevivência, temos que fazer bico no horário vago, e ai não conseguirmos sentar e fazer um grupo de iguais que enfrentem os problemas humanitários, como é que vamos enfrentar esse desafio?

A resolução dos problemas não se dará com métodos e técnicas desiguais a nós, produzidos por pessoas que pensaram nisso numa realidade de primeiro mundo ou numa realidade privilegiada de uma escola particular ou qualquer coisa do tipo. Será entre nós que vivemos os problemas cotidianos, que criaremos nossas técnicas. Será através do dialogo que aumentaremos as possibilidades de sucesso. É dito por pessoas de fora daqui, que nós brasileiros em especial, somos muito criativos. Cada um de nós encontramos os métodos e as técnicas de sobrevivência e realização, que nos permitem sobreviver no sentido de ter um pouco mais de prazer no fazer profissional, fazer profissional

é essencial para a nossa realização enquanto ser humano. Nos dias que dou aula e que não consigo despertar um envolvimento dos alunos e ficam conversando não sei o quê, eu saio e frustrado, aquilo me faz um mal, eu não consegui seduzir o grupo que estava trabalhando, pelo qual sou remunerado com dinheiro público e as pessoas entraram e sairam só para ganhar os créditos, para ter o diploma e não tiveram nenhum compromisso com aquilo que para mim é importante, é frustrante. Ter condições de romper com essas frustrações é muito importante. 
APÊNDICE 17 - OBSTÁCULOS AOS PROJETOS EDUCACIONAIS NAS ESCOLAS

A seguir são apresentados os resultados das discussões em grupo sobre a questão:

QUAIS OS OBSTÁCULOS QUE ENFRENTAREMOS PARA CHEGAR AOS NOSSOS SONHOS (DE PROJETOS EDUCACIONAIS)?

Como sensibilizar para mudar?

Burocracia.

Incompreensão.

Espaço físico (locais de reciclagem).

Aspectos politicos.

Descaso das entidades e autoridades públicas.

Falta de recursos:

humanos, financeiros $\mathrm{e}$ administrativos

Relações interpessoais.

Compromissos

diferenciados da

equipe escolar.

Quantidade de alunos

dificultando os vínculos.

Dificuldade de mudança interior e coletiva.

Falta de

estratégias funcionais.

Observação: Para informações sobre o contexto da atividade ver comentários sobre o $8^{\circ}$ Encontro no Apêndice 2. 
APENDICE 18 - AVALIACÃO dOS ENCONTROS COM A EDUCADORA "A" E COM O PROF. MARCOS. FL.1 de 6

TRANSCRIÇÃO DE FITA CASSETE $\quad / \quad 9^{\circ}$ ENCONTRO $/ \quad(03 / 07 / 1999)$

(Após os participantes se reunirem em grupos de 3 pessoas, discutirem e preencherem as planilhas de avaliação do encontro com a Educadora " $\mathrm{A}$ ", iniciou-se as explanações sobre as avaliações).

1. (Lobo) (..) Quando falou apenas uma coisa que mais gosta complicou.

2. (Parreira) Uma das coisas que a gente mais gostou, que o grupo deu mais pontos, foi a possibilidade de você falar de você. Eu que venho de uma cidade grande, a gente não tem oportunidade de conversar com as pessoas e quando você tem oportunidade de falar de você é gostoso. E vc acaba aprendendo a ouvir os outros. (Comentários paralelos sobre a fofoca em cidades pequenas). No aspecto didático... para nós foi fraco pois já tivemos contato com outras atividades, então o acréscimo não houve muito. Cognitivo também não houve muito.

3. (Vitor) Eu vou cutucá-los: a gente sempre pensa cognitivo enquanto informação técnica-cientifica. Mas ficamos sabendo informações de um grupo, informações super ricas.

4. (lara) Mas foram informações superficiais, por ser uma coisa só.

5. (Parreira) É verdade a gente, eu pensei na informação técnica-científica.

6. (Vitor) Vocês vejam que é dificil até formular a questão. Eu tentei mostrar que teria este outro lado, mas é difícil.

7. (Jade) Quando você escuta a pessoa falar que gosta de viajar, você começa a viajar, começa a abstrair junto., usa bastante (???).

8. (Vitor) É tem mais isto. Você vai junto. Isto é legal por que você se identifica com a pessoa.

9. (Vitor pede a outro grupo a avaliação).

10. (Maria J.) O que nós achamos que faltou foi o tempo para se falar mais, porque uma coisa apenas que a gente gosta. Como já foi dito nem sempre você consegue fazer o que gosta. Hoje nós vivemos presos a tantas responsabilidades com o nosso tempo, que não ... ou fazemos lá de vez em quando o que gostamos. Não sei se nós entendemos direito esta parte, nós até comentamos sobre a parte de conhecimentos, então conforme foi comentado, nós talvez tenhamos ficado presos à parte científica, ... então colocamos uma pontuação fraca. É mais ou menos o que todo mundo falou.

11. (Ceci) Nós estamos com uma pontuação mais elevada ... total 15 pontos. Acrescentando a tudo que já foi dito, falar apenas o que mais gosta já é uma ... mas nos achamos que faltava também dizer o que não gosta. O que dá uma idéia maior da pessoa, você falava o que mais gosta e o que não gosta. $O$ que achamos de legal, positivo nesta atividade é que nós fomos conhecendo um pouquinho de cada um, acrescentando um conhecimento maior do grupo.

12. (Comentários do prof. Carneiro em relação a articulação entre desejos pessoais e o dos familiares.

13. (Rosalina) Eu gostaria de fazer uma colocação... da parte do que faltou, ... depois das atividades em sala $e$ da caminhada,... na volta faltou uma explanação geral sobre o que sentiu, o que não sentiu, o que gostou e o que não gostou naquele momento, acho que isto ficou em falta ...

14. (Comentários do Vitor sobre encaminhamento da atividade.)

15. (Rosa) Demos 13 pontos,... justificando: a gente conhece outras atividades que trabalham a apresen- 


\section{APÊNDICE 18 - AVALIACÃo dOS ENCONTROS COM A EDUCADORA "A" E COM O PROF. MARCOS. FL.2 de 6}

tação do nome tão interessante quanto. (Participantes confirmam a explanação) Mas a gente acha que a contribuição pessoal foi válida, foi muito boa, porque é sempre bom ouvir as pessoas falarem o que gostam o que não gostam e a gente além disso estas atividades, dinâmicas que vocês têm colocado desinibe a gente perante o grupo, se vai brincar lá fora eu vou brincar, e vou derrubar a professora se ela passar na minha frente, você entendeu, estas atividades fazem com que a gente tenha coragem de tocar no colega... isto entre nós acho que ficou bem claro, estas dinâmicas de conhecimento, porque é se eu estou mau humorada eu vou chegar, vou falar, e os outros vão entender porque vão me conhecer... Acho que qualquer dinâmica que seja para aproximar, se conhecer melhor é legal. ...

16. (Vitor e a turma discutem a continuação e o encaminhamento da atividade em função do tempo e dos objetivos da avaliação. Vitor faz uma defesa da importância da atividade de avaliação na medida que ela consolida ganhos e socializa as percepções individuais e conclui dizendo:)

17. (Vitor) A avaliação é muito importante talvez seja melhor sacrificar alguma atividade, e fazer uma boa avaliação.

18. (...)

19. (Hortência) O que a gente conversou bastante foi sobre o exercicio de observação de campo, eles acharam que foi super, foi muito grande, eu achei que faltou e depois eles concordaram comigo... Faltou planejar o passeio, visitar mais lugares, reservar um dia só para a atividade, eles gostaram tanto que acharam que poderia ser um dia só para atividade de campo.

20. (Vitor) Agora a idéia seria completar (...)

21. (Rosa) Nós demos 20 pontos para esta atividade, achamos legal o fato de estar pertinho, podendo trabalhar com aluno e a gente, eu, nunca tinha pensado.

22. (Hortência) Você reparar mais, mudança de valores..

23. (Lobo) Eu já fiz uma uniâo entre os dois exercicio de observação de campo e de representação, acho que um complementou o outro. Esta parte de representação eu não tinha pensado não tinha feito, achei interessante, você tem que relembrar, pensar naquilo que você viu, analisar, você entra em toda esta parte. Você observou o meio, chegou aqui: vamos representar, a gente representou cada um do grupo foi falando isto, aquilo, aquilo, um foi ajudando o outro. Uma coisa interessante: um complementou o outro, isto foi interessante esta complementação. (Várias pessoas confirmam a explanação).

24. (Carneiro) Alem disso você poderia usar as próprias fotos que foram batidas, não no dia mas uma semana depois, você poderia mandar os grupos olharem Para mostrar que mesmo que você olhe muitas coisas você não enxerga. Isto é importante você se complementaria nas fotos.

25. (Safira) Uma coisa que eu pessoalmente gostei, a gente usa videos, mas a emotividade que a própria natureza passa, a vibração que vem dela não pode ser sentida de maneira nenhuma no vídeo, então a importância do contato porque envolve o emocional e o emocional é muito forte, mexe com a gente, coisa assim que mensagem fria de livro não consegue fazer.

26. (Dorotéa) .... Eu estava pensando quantas vezes eu passei por ali, como você falou do emocional, ... nesta correria essa coisa, eu nunca observei nada. Como ali gente sai com este objetivo...

27. (Ceci) Agora você passa de uma outra forma.

28. (Comentários sobre o monumento que fica na entrada da cidade. 
APÊNDICE 18 - AVALIACĀO DOS ENCONTROS COMA EDUCADORA "A" E COM O PROF. MARCOS. FL.3 de 6

29. (Parreira) O nosso grupo fez uma observação que a atividade de aquecimento do grupo contribuiu muito para esta atividade de observação de campo. Pois se nós não tivéssemos um contato mais próximo com as pessoas, na atividade de campo talvez não tivéssemos conversado, não só o que estávamos observando, mas também assuntos que não tinham nada haver com a situação em sí... Esta coisa do corporal-afetivo contribuiu muito para depois quando saímos em campo tivéssemos um contato mais pessoal na visita.

30. (Lobo) Pegando o que ele estava falando, acho que ela já fez um planejamento geral de tudo, teve uma seqüência bem lógica do que ela começou. Teve apresentação individual; depois teve apresentação em conjunto; depois entrou com a parte da tampinha, observar realmente que na técnica de observação aparece um monte de coisas (...), então vamos observar: o que pode fazer com isto? Para a gente ficar espertos e depois a gente sair. Ai foi a atividade de campo, a gente estava treinadinho para observar.

31. (Parreira) (Interrompendo o colega) Tem a diversidade de observação também, você sai para 0 campo, talvez o que ele observa não é interessante mas eu vou ter que aprender a respeitar.

32. (Lobo) ... E por último, que achei mais interessante, que eu não tinha trabalhado, foi esta parte de representação. Então teve um fundamento, e este fundamento que é interessante, nós mesmos no dia a dia fazermos esta preparação.

33. (Vitor) Realmente eu e a convidada nos encontramos antes. Então ela falava: posso fazer isto? Não, nós já fizemos algo parecido. Nós escolhemos o lugar, eu estava curioso com aquele lugar (...) quando ela falou se tinha algum lugar interessante para visitar, eu falei acho que sei qual o lugar. Então houve um planejamento antes.

34. (Jade) Um procedimento didático-pedagógico.

35. (Vitor) E... (...) Vamos fechar? Talvez seja interessante a gente falar sobre aquela parte em que ela começou, ela tentou falar. E ai entra a questão de como proceder depois que a gente ateou fogo na fogueira, depois que as pessoas estavam mais livres para falarem, mais excitadas com informações e descobertas, ela não conseguiu falar muito, porque a gente tinha muita coisa para falar... conversar...

36. (Safira) Eu vim esperando muito sobre os aspectos da transversalidade, como agir, como trabalhar. Emtão viemos pensando numa coisa e esta atividade de campo mexeu o lado emocional, este lado tomou comta e o restante ficou sem, eu pelo menos achei que faltou um conteúdo cognitivo maior, que eu estava esperando.

37. (Parreira) Técnico-cientifico. (Várias pessoas falando junto e concordando com a fala anterior).

38. (Ceci) Como trabalhar o tema transversal meio ambiente?! Com relação a isto nós não tivemos...

39. (Vitor) Vocês lembram, ela tentou, mas a gente estava muito fortes (?) ...

40. (Ceci) A mesma coisa aconteceu com a O: pouco ela falou sobre práticas orgânicas. Ela falou nada. Nós ficamos foi maravilhoso, chegamos um momento que ficamos...

41. (Vitor) Com a $\mathrm{O}$ era outra situação

42. (Safira) A O trouxe outras coisas e nós não saimos insatisfeitos. Agora esta, bolou a tranversalidade, a gente veio esperando uma série de informaçōes técnicas para trabalhar. Na atividade de campo tudo é muito sutil e mexe só com a parte emocional, então o lado racional: que conteúdo que vamos receber ficou deixando um vazio para a gente.

43. (Vitor) Ninguém falou, mas nós perdemos um tempão logo na chegada, começamos as 9 apesar de chegar-mos as oito e meia. Houve um desentendimento (...) ela também queria começar e ficamos esperando 
APÉNDICE 18 - AVALIACÃO dOS ENCONTROS COM A EDUCADORA "A" E COM O PROF. MARCOS. FL 4 de 6

o café e acabamos encurtando o tempo. E a estória de voltar, que nunca a gente consegue fazer com o tempo combinado.

44. (Parreira) É o tempo foi crucial.

45. (Ceci) É, estas saídas tem que ser o dia todo.

46. $(\ldots)$

47. (Vitor) Eu acho que deu para a gente ter uma idéia. A Cida ficou mais ou menos sabendo o que sentimos naquele dia. Acho que este é um elemento legal para avaliação, uma pessoal que estava de fora e ficou sabendo.

48. (Cida) Eu até coloquei na minha cabeça como tivesse participado. Como é que foi... Eu vi as fotos com aquela lista no quadro e não tinha entendido o que era, ai eu vi que era a observação da tampinha... Então ficou muito claro para eu saber o que aconteceu e até o que deu certo e o que não deu. Achei que foi muito legal. Eu não estava presente, (...) vocês fizeram uma boa avaliação.

49. (Lobo) Foi uma avaliação geral.

50. (Cida) E juntou as fotos, que é o registro importantíssimo, e tudo que vocês falaram ...

51. (Vitor solicita sugestões de encaminhamento para a avaliação do encontro como professor Marcos. Os cursistas começam a conversar entre si. Instaura-se um grande falatório. Vitor lembra que a primeira atividade foi a apresentação do nome e de características pessoais usando as letras do nome. Várias pessoas fazem comentários simultaneamente, dos quais se destacam:)

52. (???) $\quad$... A gente faz sempre apresentação, esta foi diferente...

53. (???) ... Foilegal.

54. (???) Incentivou bem todo mundo.

55. (???) Dá mais abertura para a pessoa falar mais de si... tanto que o Francisco que queria falar tanta coisa que colocou o nome inteiro.

56. (???) Eu gostei.

57. (???) Amei.

58. (Ceci) Nós até comentamos em casa.

59. (Vitor) (...) Faltou alguma coisa nesta atividade? (...) Alguém teria uma idéia para complementar?

60. (...)

61. (Safira) Eu acho dificil trabalhar isto numa classe de 45 alunos, este é o nosso grande problema...

62. (Vitor) Na primeira semana de aula talvez fosse o espaço para isto, mas ai tem que pensar se é interessante atear fogo na criançada logo na primeira semana.

63. (Violeta.) Eu achei uma das atividades que faz com você use o seu raciocinio, você tem que parar para pensar $(.$.

64. (Lobo) Você fica pensando (...) não pode colocar qualquer coisa (...).

65. (Diversos participantes e o Vitor fazem considerações sobre a técnica do prof. Marcos para a memorização dos nomes dos participantes. Vitor pergunta sobre o que aconteceu depois.) 
APÊNDICE 18 - AVALIACÄO dOS ENCONTROS COM A EDUCADORA "A" E COM O PROF. MARCOS. FL 5 de 6

66. (Ceci) Depois ele falou bastante, eu senti na explanação dele, no jeito dele falar: o conhecimento que ele tem do assunto é muito profundo.

67. (Jade) Só que gente inteligente assim tem hora que dá um branco,

68. (Ceci) Teve uma hora que ele parou, a palavra parece que não vinha, depois ele continuou.

69. (Rosa) Sabe o que achei, foi legal o que ele estava falando (...), mas só que era tanta informação de uma maneira simples que ele estava passando que não dava tempo de acomodar uma informação e ele já estava falando outra coisa.

70. (Cida) Não era simples não, era bem elaborado, dava para entender se você ficasse bem atenta, se você fugisse um pouquinho, adeus. (...) O vocabulário era simples, mas como ele laçava as palavras (muitas pessoas comentando junto). Mas ao mesmo tempo era uma coisa gostosa, porque você conseguia prestar atenção (outras pessoas confirmam a explanação). (...) Quando a pessoa começa a rebuscar muito eu acho mais fácil você ler do que ouvir, no caso de estar trabalhando com coisas muito elaboradas melhor é você ler para ter um tempo de acomodar, as vezes você ouve e acaba se desligando e não entendendo. Mas no caso dele não, eu nem fiz muito esforço para prestar atenção, eu realmente fiquei ali... deu para acompanhar.

71. (Oliveira) Ele mesmo comentou que iria parar de falar um pouco senão a turma iria dormir, mas pelo contrário, estava todo mundo experto.

72. (Jade) É uma técnica de comunicação densa, as pessoas ficam olhando e prestam mais atenção. (...) Agora se é muito dificil e a pessoa não se olha a comunicação se torna fria.

73. (Carneiro) Eu achei que ele falava, mas de vez em quando ele parava dando brecha para ir em cima dele, para se questionar, (...) ele falava não só no sentido de expor mas no sentido de interrogação, provocação.

74. (Comentários do Vitor sobre sua experiência com o prof. Marcos.)

75. (Jade) (...) Eu vejo assim tem muito conteúdo de educação ambiental, que a gente não sabe. Quanta coisa que tem, conceitual, muito profundo.

76. (Safira) Outra coisa que eu senti, não é um discurso vazio é um discurso de quem vivencia aquilo e ai a gente cai na rotina do dia a dia da gente e fala: "Puxa-vida' como professor, o quanto ainda eu tenho que correr atrás"

77. (Ceci) Quanta areia eu tenho que por no meu caminhãozinho.

78. (Safira) É eu fico até meio chateada, tem pessoas com tanto conteúdo que foi conquistando com o tempo e trabalha em cima disto. E a gente? O que será que eu consegui? A gente faz um paralelo e fala nossa eu tenho muito que aprender.

79. (Rosa) Ai eu falo: quando eu crescer quero ser igualzinho.

80. (Hortência) (...) Há anos que ele trabalha.

81. (Vitor) É ele tem uma dedicação especifica, vocês também têm, a Safira tem uma dedicação especifica na escola. Com certeza na escola vocês são melhores que ele.

82. (Safira) Mas a gente não consegue ver o peso da palavra dele nas aulas que a gente dá. Ai que a gente fica: posa vida ele cativa todo mundo o os meus 45 eu não consigo cativar. Eu fico triste.

83. (Hortência) Você acha que se nós tivéssemos a idade de nossos alunos ele conséguiria cativar? 
APENDICE 18 - AVALIACÃO DOS ENCONTROS COM A EDUCADORA "A" E COM O PROF. MARCOS. FL. 6 de 6

84. (Vários comentários simultâneos.)

85. (Vitor) Será que se nós colocarmos ele lá na sala com os seus alunos ...

86. (Cida) E mesmo lá na universidade tem muito aluno dele que não está nem ai.

87. (Vários comentários simultâneos.)

88. (???) Ele também tem suas frustrações, ele falou (...).

89. (Comentários do Vitor sobre problemas na Universidade.)

90. (???) Eu achei legal escrever na folhinha o sonho, (...) ele falou para fechar os olhos e imaginar.

91. (Rosa) Antes disso ele falou de compromisso individual: Como cada um se aproxima da questão ambiental? Achei interessante isto. Um se aproxima por causa das relações humanas, (outras pessoas acompanhando e complementando a fala) alimentação, proteção da natureza... A porta de entrada.

92. (Lobo)) São várias portas.

93. (Rosa) Achei legal ele ter colocado isto (...) achei interessante a questão da porta de entrada para trabalhar o compromisso.

94. (Vitor) Tem um texto do Marcos que trata sobre o que a Rosa falou: as várias formas de acessar a questão ambiental, eu vou traze-lo, eu me esqueci que tinha isto em casa.

95. (Vitor vai listando as atividades do dia.) O que esperava da escola (individual, duplas e grupos de 4) ai passamos a discutir os obstáculos, (...) depois foi lembrar outros projetos (...) relatos (...), ai reformulou-se os grupos por escola para cada um fazer seu projeto.

96. (Vitor) Estas etapas: pensar os sonhos sem estar tão presos, partindo do individual (...), pensar os obstáculos, pensar outros projetos como referencias, são estratégias para tentar fazer com que o projeto nasça mais forte.

97. (Lobo) Na hora que ele abre para os sonhos, no sonho cabe tudo, ai você monta um projeto naquele visual seu (...) sua utopia, e para você alcançar tem que trabalhar muito nisto, ai vai sair um projeto bem mais forte neste sentido. Se você pensar racionalmente vai pensar num projeto pequeno, porque vai ver todos os obstáculos na sua frente. (...) Racionalmente é terrivel.

98. (Carneiro) É a coisa de pensar nos desejos sem pensar nos obstáculos, ou seja pensa no que você quer fazer, depois você vai executar, ai você vai se virar.

99. (Vários comentários simultâneos sobre esta estratégia.)

100. (Jade) Aqui na região no ano passado o Instituto Parreira Freire, teve um projeto do pessoal PECA (?), a estratégia deles era esta: a própria comunidade, professores, direção fazia o projeto da escola, a técnica deles era esta: levantar o marco referencial que eles falavam, pegar o referencial dos professores, qual o sonho dos professores, mas não só com os professores (...) perfil dos alunos, perfil da comunidade, depois tem que ver a prioridade da escola. Porque tem muita coisa que o pessoal quer fazer e tem que ver qual a prioridade. 0 Marcos falou também das prioridades. Toda esta região foi trabalhada pelo Instituto Parreira Freire.

101. (Outras pessoas comentam sobre este projeto lembrando que ele não teve andamento.)

102. (Parreira) O projeto esta guardado na escola, ninguém executou (...)

FIM DA TRANSCRIÇÃO 


\section{APÊNDICE 19 - RELAC̄ÕES ENTRE DISTINTAS FORMAS DE MEDICINA}

Algumas diferenças entre: medicina convencional, medicina tradicional e homeopatia * Subsidios para reflexões sobre agricultura convencional e agricultura alternativa

\begin{tabular}{|c|c|c|}
\hline $\begin{array}{l}\text { Tipo de Medicina } \\
\text { Proposta }\end{array}$ & CONVENCIONAL & TRADICIONAL \\
\hline Modelo de indivíduo & $\begin{array}{l}\text { Material / mecânico } \\
\text { (Compartimentado) }\end{array}$ & $\begin{array}{c}\text { Integral } \\
\text { bio-fisico e espiritual }\end{array}$ \\
\hline Concepção de vida & $\begin{array}{l}\text { Possibilidade de } \\
\text { material único }\end{array}$ & Momento da existência \\
\hline Objetivo & $\begin{array}{c}\text { - Supressão do } \\
\text { desconforto da dor } \\
\text { (Atingro sintoma, causa fisica) }\end{array}$ & $\begin{array}{l}\text { Re-conectar o } \\
\text { ser humano ao todo, } \\
\text { ao fluxo da natureza }\end{array}$ \\
\hline Metas & $\begin{array}{l}\text { - Prolongar a vida } \\
\text { - Desfrute material }\end{array}$ & $\begin{array}{l}\text { - Dar suporte p/ experiência } \\
\text { - Aproveitar o instrumento } \\
\text { senso-perceptivo }\end{array}$ \\
\hline Método de pesquisa & Análise enfocando a parte & $\begin{array}{l}\text { Contemplação do todo e do } \\
\text { indivíduo (caráter ecológico) }\end{array}$ \\
\hline $\begin{array}{l}\text { Localização do objetivo } \\
\text { da experiência }\end{array}$ & $\begin{array}{l}\text { - Exterior: Alienação do } \\
\text { que sente o pesquisador } \\
\text {-O objeto está fora }\end{array}$ & $\begin{array}{c}\text { - Intra-psiquico } \\
\text { - Intuição / percepção }\end{array}$ \\
\hline Fonte & $\begin{array}{l}\text { Conhecimento nascido da } \\
\text { pesquisa objetiva-teórica }\end{array}$ & Sabedoria universal \\
\hline
\end{tabular}

Quadro - 2

\begin{tabular}{|c|c|c|}
\hline $\begin{array}{l}\text { Tipo de Medicina } \\
\text { Proposta } \\
\end{array}$ & CONVENCIONAL & HOMEOPATIA \\
\hline Anaminese & $\begin{array}{c}\text { Busca da sindrome que } \\
\text { caracteriza a doença }\end{array}$ & $\begin{array}{l}\text { Contempla e percebe } \\
\text { o paciente buscado sua } \\
\text { forma individual de sofrer }\end{array}$ \\
\hline Diagnóstico & da doença & do individuo \\
\hline Terapêutica & - Para a doença & $\begin{array}{l}\text { - Para o individuo } \\
\text { - Independe da doença }\end{array}$ \\
\hline Objetivos do tratamento & $\begin{array}{c}\text { Controle ou desaparecimento } \\
\text { dos sintomas } \\
\text { Evitar morte }\end{array}$ & $\begin{array}{c}\text { - Bem estar geral } \\
\text { - Realização do indivíduo } \\
\text { - Recuperação da sensibilidade }\end{array}$ \\
\hline
\end{tabular}

* Fontes: transparencias e comentários do Homeopata Fernando Bignardi durante Palestra-oficina, para detalhes ver Apêndice $2-10^{\circ}$ Encontro. 
APÊNDICE 20 - CONSIDERAC̄ŌES SOBRE A CONSTRUCAÃO DE UMA HORTA ORGÃNICA NA ESCOLA FL. 1 de 9

\section{PALESTRA-OFICINA DO PRODUTOR ORGÂNICO "G" SOBRE A IMPLANTAÇÃO DE UMA HORTA ORGÂNICA NA ESCOLA (TRANSCRIÇÕES DAS FITAS-CASSETE DO $12^{\circ}$ ENCONTRO)}

\section{FITA 1 (PEQUENO TRECHO)}

(G) É importante que as pessoas estejam embasadas, que elas saibam o que estão falando e que estejam aprendendo. Estamos todos em processo de aprendizagem, eu estou quebrando Jasmim lá a uns 4 anos e eu sinto que a cada dia que passa, parece que de ontem para cá que eu aprendi mais coisas. Temos necessidade de aprender muito, diferente do agricultor convencional, que não precisa aprender muito, por que? Porque ele não tem uma preocupação com o total, ele tem uma preocupação só com a produção, ele tem uma preocupação só econômica e para isto as lojas de insumo têm respostas. 0 camarada nunca plantou um tipo de produto, qualquer coisa, ele está acostumado a plantar alface, alface, ... resolve plantar abobrinha ele chega lá na loja e fala: 'Estou com vontade de experimentar abobrinha, o que que eu faço? O cara já dá para ele uma receita, ele vai aplica e dá certo. Porque ele não tem muita preocupação, ele esta fazendo algo quase artificial, ele usa o solo simplesmente como um suporte, ele não usa o solo como parte do processo, se ele arrumar outro suporte ele vai usar.

(Vitor fala acompanhando a argumentação do G): Isopor e água.

(G) Para o agricultor convencional é fácil, simples, só que os prejuizos são muito grandes. As pessoas geralmente não têm noção, como é um prejuízo que vai se acumulando aos poucos, e muitas vezes depende de um entendimento. Você tem que entender o que é um processo de erosão, o que é um processo de degradação do meio ambiente. Entender que os resultados vem daqui algum tempo, não é uma coisa imediata, não é como plantar um pé de alface, colher e pegar o dinheiro, é bem diferente.

(Vitor) Demora alguns anos.

FIM DA FITA 1 - INICIO DA FITA 2 LADO A

(G): A erosão o que é? A erosão é a gota de água que bate no grânulo de terra do solo e dissolve, isso é erosão, é aí que começa o processo de erosão. O fato de juntar água e formar aquelas voçorocas vem depois desse processo. (...) É importante que o canteiro esteja coberto sempre, ou pôr plástico ou pôr material orgânico (palha) tem que ter uma cobertura morta que impede o impacto das gotas da água com o grânulos de solo, aí não acontece erosão.

(Flora): Viu G, seria um tipo de serragem....

(G): Vou explicar para você. Serragem não deve usar. Uma outra coisa que eu achava legal para isso é jornal. Jornal tem em quantidade e é só triturar e cobrir os canteiros, mas não pode, porque temos metal pesado no jomal.

(Rosa) E o plástico?

(G): Se você tiver um plástico de boa qualidade, então você vai ter um plástico durável, ele não vai estragar muito rápido, se decompor. De certa forma há uma interferência, mas interferência há de qualquer forma, porque nós estamos interferindo. A partir do momento que a gente faz agricultura, a gente está interferindo. Mas o plástico, se for um bom plástico, então ele não vai ressecar rapidamente, não vai soltar pedaços.

(Safira) A serragem não é boa pôr causa das substâncias químicas que ela vai liberar?

HOMEM (G): Eu vou explicar o porque da serragem. O problema da serragem é o seguinte. São fibras muito unificadas e duras, dificil de se decompor. Então, no processo de decomposição, enquanto a gente coloca a serragem pôr cima do solo, enquanto ele está só por cima do solo, não tem problema, porque ela vai estar na superficie, ela 
APENNDICE 20 - CONSIDERAÇÕES SOBRE A CONSTRUÇÃO DE UMA HORTA ORGÂNICA NA ESCOLA FL.2 de 9

vai roubar um pouquinho de nutrientes para a própria decomposição, mas é pouco. Mas a partir do momento que a gente dá uma incorporadinha nessa serragem, ... ela vai roubar toda energia que tem no solo para decomposição, (...) porque os microorganismos que vão decompor a serragem precisão de nutrientes. $E$ esses nutrientes eles vão tirar do solo, então empobrece o solo e nós não vamos produzir naquele solo.

(Safira) É a mesma coisa com a cama de pintinho?

(G) A cama de pintinho eu já não sei a diferença da cama de frango, para a cama de frango se tiver muita palha é ruim pelo mesmo fator. A gente tem que trabalhar com muita palha, certo?! Mas de preferência uma palha de demora de decomposição média. A palha que se decompõe muito rapidamente também não é bom porque ela demora pouco, ela surte pouco efeito.

(Safira) E estes bagaços de mamona, torta de mamona?

(G) Torta de mamona: aquilo é excelente Usando torta de mamona não precisa usar mais nada, porque ele é uma adubação completa, aquilo é muito bom A torta de mamona é um farelo de quando se extrai o óleo, amassa a mamona então aquela sobra é a torta de mamona. Ela seca e aquilo é excelente é muito bom .Uma coisa que a gente usa o bagaço de cana. Bagaço de cana é bom trituradinho, só que o bagaço de cana faz o mesmo que a serragem, com uma intensidade bem menor, mas ele pode fazer. Então o ideal seria a gente não incorporar a matéria orgânica, a gente faz a cobertura, essa é a idéia do canteiro definitivo de não mexer com máquinas. (...) A gente faz os canteiros, faz a cobertura e deixe que a própria natureza incorpore aquilo tudo, porque aquele material vai se decompondo e os bichinhos vão fazendo este trabalho de incorporação nos solos. Só que uma coisa é esta teoria a outra coisa é a gente enfrentar essa prática. Porque na verdade quando a gente planta lá, enche de mato, mesmo com a cobertura morta, você começa a arrancar o mato ai você percebe que o chão esta duro. Você quer pôr a muda lá, o chão está duro, como você vai fazer então? Você tem que se adaptar a esta prática.. Tem um pessoal do plantio direto que faz algo que funciona muito bem: eles plantam adubação verde e depois roça aquela adubação e vem com as máquinas que faz os sulcos no meio daquela palha e vai depositando as sementes. Então a gente tem que achar este caminho para a horta, tem que descobrir o próprio manejo. Eu lá, eu estou construindo na enxada, na mão mesmo, não tem máquina. Fazemos canteiros que não serão desmanchados, e estou usando esta técnica do plástico. Mas para usar essa técnica do plástico, nós temos que ter um nivel de matéria orgânica muito bom no solo; para fechar e aquilo ficar no solo. Com uma qualidade boa lá em baixo, senão, ai você não tem que ficar interferindo.

(Vitor): Será que você não prejudica muito a vida de microorganismos com o plástico?

(G): Com o plástico, eu acho que o plástico vai reduzir um pouco a atividade dos microorganismos no solo. Ele vai causar uma pequena interferência. Mas aí, você tem que ter uma preocupação muito grande em devolver uma quantidade de matéria orgânica que sege realmente adequada que é pró solo, para você compensar isso. Dá para fazer um manejo assim: no verão você usa plástico, e no inverno você trabalha sem plástico, nesta época você repõem. Mas eu estou querendo trabalhar com o plástico sempre, eu tenho um problema sério com mão de obra, então eu quero ver se trabalho com plástico sempre; sempre fazendo a reposiçąo. O manejo que eu estou fazendo é assim, eu uso plástico com uma furação, e nessa furação eu planto tudo. Eu faço uns 15 buraquinhos pôr metro, ai eu faço rotação nesses buracos, com espaçamento adequado. Deixa eu explicar uma coisa para vocês, tem algumas coisas na horta que são muito importantes e que as pessoas as vezes não dão muita importância. Que é o manejo em si, que é o preparo de solo, as formas de fazer o canteiro, tudo isso; a adubação, uma aduba ção adequada é de extrema importância; o espaçamento entre as plantas isso é de extrema importância. E outra, estende, a gente precisa olhar para uma horta $e$ ver uma coisa bonita. A partir do momento que voce olha e vê uma coisa bonita, significa que a horta está indo bem. Se você olhar. tá um pé aqui, um pé ali, uma coisa meia 
atrapalhada, a horta não vai bem, porque não é só aquilo que não vai bem, são um monte de outras coisas que não vão bem. Você não chegou ainda onde deveria ser. Porque tem gente que as vezes, numa ponta de canteiro tem 5 pés de alface num metro na outra ponta tem 16,20 , não!, você tem que ter organização, tem que ser uma coisa metódica, organizada. Por exemplo a alface, a gente planta 9 pés de alface por metro quadrado, varia, tem gente que planta 12,10 , eu acho que é um espaçamento legal. Alface, escarola, almeirão eu planto 15 por metro quadrado. Os canteiros foram a minha maior dificuldade, eu passei alguns anos tentando que meus canteiros saissem da mesma maneira. Nos canteiros você reduz o espaçamento entre as plantas, ou você alarga o espaçamento, ou então você tem que espremer para que elas caibam. Então você tem que ter organização, uma das organizações é você manter canteiros da mesma largura. O ideal seria que os canteiros pudessem ser em curva de nivel. Mas se eu não consigo na minha horta fazer canteiros da mesma largura, retinhas assim.

(G) Porque a gente trabalha com mão de obra de qualidade a baixo de zero, as pessoas não entendem coisas simples, não entendem o óbvio. Se o cara não fizer o canteiro da mesma largura que o outro, a planta não vai ficar no mesmo espaçamento uma da outra, certo. As pessoas não conseguem entender isso. Até pouco tempo eu trabalhava com mão de obra... eu corria atrás de um monte de coisas, então meu tempo no sítio era muito reduzido, até que eu fui chegando a conclusão que não dá. Eu tenho que parar no sítio. Então eu achava que eu tinha que pôr gente para trabalhar lá, e eu ia fazendo outras coisas. Ou eu to lá ou o sítio não vai para frente. Então não se entende esse tipo de coisa; ou se entende mas não se pratica, não dá importância, acha que não tem importância esse tipo de coisa, então os canteiros um tinha $80 \mathrm{~cm}$, outro 120 , outro tinha 50 , outro tinha 90 , absurdo. Então foi de pouco tempo para cá, que eu consegui, que estou conseguindo fazer as coisas; fazer os canteiros da mesma largura, quase da mesma largura, ai eu tive que construi uma ferramenta para botar a linha de um lado, do outro. Pô, mas não é possivel, tem linha aí. Se finca um negocinho de lá, um negocinho de cá, estica a linha e faz o canteiro. Não tem jeito, não saía de jeito nenhum. Então agora eu resolvi fazer pessoalmente os canteiros. Todos os canteiros que estão lá eu que fiz.

(Lobo): Qual a largura?

(G): O meu canteiro tem um metro.

(Safira) O senhor falou um negócio: viu que tem que está no sítio p'ra coisa ir p'ra frente, e naquele artigo que eu dei para o Vitor da agricultura sustentável em Capão Bonito, ele também fala que a vida dele é lá, que ele não sai de lá. Ai não conflita com a vida atual do homem, da familia? Hoje é compromisso com o filho, eu tenho que ir lá. No artigo dizia também, sábado e domingo a familia se reveza para ficar lá. E que ele é feliz e não sente necessidade de compromissos lá fora. Mas no mundo de hoje, é fácil viver essa vida com filhos adolescentes? Como é que fica?

(G): Os meus filhos ainda não chegaram na vida adolescente, ainda estão pequenos. Vão começar a vida escolar no ano que vem. Mas eu acho assim: eu fiz uma opção.

(Safira) Mas é a opção do papai, o filho ainda não é.

(G): Mas nós fizemos a opção assim. Eu achava que queria largar a vida em São Paulo, de ser empregado, e tocar esse lado que era mais importante, mais gratificante que eu vivia lá. Aí viemos para cá O problema econômico ele começou, piorou. Eu tinha um salário, que eu reclamava, achava pouco, mas que tinha sol ou chuva estava lá., eu podia contar com ele, planejar com ele. Quando eu vim para cá, mudei tudo. Esse era o grande medo, perder a estabilidade, perder essa coisa do salário todo mês, ai vim para cá e comecei a correr com um monte de coisas, que eu achava que não podia tirar o meu pé de lá porque eu tinha que continuar com os projetos lá, com meus trabalhos lá, onde me rendia uma grana até o sítio levantar e me dar o retorno para que eu pudesse largar os trabalhos lá. Eu sonhava até em continuar tocando o trabalho lá, porque eu montei uma empresa de consultoria 
e biblioteconomia. Então eu fazia esse trabalho lá em São Paulo. Eu sai, mas continuei trabalhando nessa área, e eu fazia um comércio de verduras, eu produzia um pouco, pegava um pouco dos vizinhos, montava uma sacola entregava em São Paulo. Eu ficava até meia noite, 1 hora montando sacola, ai no outro dia saía as 5 da manhã para São Paulo entregava, ainda passava nos pontos que estava desenvolvendo trabalho de biblioteconomia. Quer dizer, estava maluco.

(Flora) Só uma pergunta, sua mulher aceitava tudo isso? Não deu uns conflitos? Quando fomos te visitar, fizemos um comentário com o Lobo: Ele tem um menininho dele, a criança é pequinininha, agora de repente pegar uns aqui (da escola) que está acostumado né... cheio de marca, modemão e socar lá, eles não vão.

(Safira) Choveu! Não dá para ir para a festa".

(Flora) E dai, G, querendo ser discreta. (risadas)

(G) A Cátia também, ela saiu da cidade, ela trabalhava no arquivo do Estado, era funcionária pública também. É historiadora, fez história, e viemos para cá, para realmente mudar. Então ela acredita nesse projeto, ela vestiu a camisa mesmo, se ela não acreditasse, não tivesse vestido a camisa ai sim os problemas teriam sido muito maiores, né. E nessa correria toda, claro que gerou uma série de problemas, não problemas com ela por isso, mas problemas mesmo, que eu sentia que eram problemas, porque eu sentia que era inviável, era impossivel continuar fazendo aquilo. E o sítio nunca levantava, porque eu chegava o negócio tava errado, o que tinha ficado para fazer não tava feito. Ai nós fomos abandonando este tipo de trabalho, fui largando e ficando só no sítio. Então a renda que a gente tinha que era maior, ela foi caindo; mas eu falei: Ou eu, a gente chega lá no fundo do poço mas constrói o sítio, ou a gente desisti, vai virar comerciante, vai virar bibliotecário, vai virar outra coisa, mas não vamos fazer o sítio. Ai nós optamos realmente pelo sítio e eu ainda faço este tipo de coisa aqui, o que eu estou fazendo. Eu dou um curso de agricultura para os "sem terra", eu tenho feito algumas atividades assim, que gastam um dia por semana. É interessante que as vezes me desafoga em termos econômicos, as vezes entra um dinheirinho desses cursos, então dá uma ajuda. Eé uma coisa importante para eu em termos de realização prá que eu consiga passar esse processo, que eu consiga interferir em outras pessoas com esse tipo de trabalho que eu estou fazendo, que não é meramente econômico, só produzir, vender e gastar o dinheiro. Então tem sido muito compensador, eu tenho gostado muito deste trabalho que eu estou fazendo. Eu só preciso ganhar um pouquinho mais de dinheiro. Eu sinto que de seis meses prá cá, é que a gente deu um salto em termos de qualidade, que foi quando eu assumi algumas etapas do processo, por exemplo fazer canteiro, pegar a enxada e fazer canteiros.

(Peri) Na agricultura convencional, o cara que é agricultor mesmo, ele tem essa vivência, tá quotidianamente na terra, pode fazer umas coisas erradas, mas ele não está sempre lá?

(G) Essa é a diferença. Para o agricultor convencional, esses problemas que eu to tenho, eles não tem mais, ele já passou por isso, a máquina mede. Eles têm uma prática tão grande que o cara vai plantando e já sai tudo no espaçamento correto.

(Amélia) Apesar de ser convencional, ele já nasceu nisso, o pai era, o avô era.

$(G)$ : Exatamente, ele tem um manejo. E muitas outras vezes, o agricultor vive só aquilo. As vezes ele é estreito, ele não tem um horizonte tão largo, então ele não vê outras necessidades, cinema, festa, nada disso. Ele é simplesmente agricultor, ele não sofreu interferência, influência de coisas que nós sofremos na cidade.

(Safira) A maioria dos jovens fazia até $4^{\circ}$ série e ficava lá no sítio. Agora a prefeitura dá passe e trás para o colegial todo mundo, então aquele sonho de adolescente do sítio já não é de seguir o pai, riscar a terra e plantar. Agora quer curtir um shopping, um cinema... 
(Peri) Embora aqui seja uma cidade agrícola, houve uma perda de valor, esses garotos não valorizam mais - que os pais fazem, querem é mais distância da zona rural. (Vários outros participantes confirmam a fala)

(Amélia) Eles têm até vergonha de falar. (Novamente vários participantes confirmam a fala)

(Peri) Inclusive uma idéia desse projeto é tentar reconstruir para esses garotos, que é uma prática que tem todo valor.

(G) É inconcebivel para aos meus pais que eu seja formado pela Universidade de São Paulo e estou trabalhando na enxada, se ainda tivesse com trator, tudo bem.

(Flora) E uma realidade. A gente fala pro filho da gente, eu mesma falo para minha filha que está fazendo faculdade: Invista em você, não fique parada no tempo e espaço, se amplie. Não fique arranjando namorado e já casando. Vá e saia daqui para você ter uma visão melhor das coisas. Eu até aceito a idéia de seu pai, porque é triste, G.

(Momento de descontração, alguns participantes fazem comentários sobre suas histórias de vida).

(Peri): Pela realidade que a gente vive, você falou uma coisa interessante no início.. A agricultura orgânica até pelas condições específicas que ela coloca hoje, é praticada geralmente por pessoas que são de classe média, média-alta, e geralmente uma classe média intelectualizada. De repente, o perfil desse agricultor orgânico ele é muito destinto do perfil do agricultor tradicional. 0 grande problema é o seguinte: não dá para ter esse periil. Por exemplo, você tem esse perfil, mas você de certa forma é "forasteiro", você saiu de um universo urbano e por opção se inseriu num universo rural. Agora para se construir uma nova geração de agricultores não convencionais, agricultores orgânicos, essa nova geração não pode abrir mão desse contato com o urbano, e como é que se concilia isso?

(G) Para mim foi de extrema importância eu ir para a Universidade.

(Vários participantes fazem comentários confirmando a fala anterior)

(G) Para mim é de extrema importância que as pessoas tenham escolaridade. Nós precisamos de agricultores com a cabeça aberta. Não é assim: quem vai para roça não precisa estudar, ao contrário, nós precisamos de pessoas que tenham a capacidade reflexiva, para entender tudo isso. Se não, ele vira meramente um robozinho de plantar alface, que é o que acontece com a maioria das pessoas, ele não consegue enxergar nada além dos reais que vai receber pelos pés de alface que está plantando. Pô é a vida das pessoas, se você não tiver o mínimo de entrosamento com aquilo que você está fazendo, o minimo de prazer com aquilo que você faz...

(Peri, completando a frase do G) Você vai ser um trabalhador alienado, seja no campo ou na cidade.

(Flora) Então G, para o jovem de maneira geral, essa agricultura orgânica, se você começar a vender esse produto como sendo chique, moderno, da geração dos universitários, com cabeça legal, ai eles entram nesta. Agora se você falar que é daqueles tempos da Dona Flora ... (risos). Então tem esse lado, você tem que convencer a pessoa, fazer a mídia.

(G) Vamos voltar ao canteiro. Têm coisas extremamente importante, que as pessoas não dão importância. Por exemplo (...) o espaçamento entre um canteiro e outro, porque se a gente fizer um canteiro muito apertado, a gente vai andar pisando nas beiradas do canteiro, ai tem o conforto do trabalho que você está fazendo. Esse espaçamento deve ser no minimo 30 ou $40 \mathrm{~cm}$, porque senão você não consegue... Depois entra a questão do espaçamento entre as plantas... Ah, outra coisa a profundidade disso aqui, vocè tem que fazer uma drenagem, tem que drenar.

\section{FITA 2 - LADO B}


(G) A água é importante para ajudar a planta a incorporar os nutrientes que precisa, não em excesso porque senão causa problemas para a planta também, tem que ter água na quantidade ideal, não pode ser muita água, e ele não pode segurar a água, porque se ele segurar a áqua o que vai acontecer, vai apodrecer as raizes da planta $e$ ela não vai para frente. Tem que ter uma profundidade de 20 a $30 \mathrm{~cm}$ de canteiro, então vocês imaginam mais ou menos assimf\}o canteiro deve ter de altura. É importante, no verão a gente tem um volume de água muito grande, um volume de chuva muito grande, porque melhor que sege o solo, por melhor que ele drene, se os canteiros não tiverem bem feitos, você vai ter um enxarcamento, você passa uma semana chovendo, tem que drenar bem.

Ai varia às vezes, de solo para solo, tem solo que drena melhor.

Como a minha horta é a minha casa, eu resolvi fazer uns drenos numa largura que eu possa ficar de lado numa boa, que caiba o meu pé e sobre mais um pouco. Senão como eu vou trabahar assim.

MULHER: Mesmo o pessoal lá em João Dias, quando estavam tirando lá as ervas, eles estavam mal acomodados, porque quando eles abaixavam, eles batiam a bunda no outro canteiro.

G: Tem que ter um certo conforto, mas nesse espaçamento aqui dá. As máquinas, as rotos-encanteadeiras, já tem um padrão. Quando o cara vem com o trator, ele já vai deixando tudo certinho. O canteiro sai certinho, sai tudo na mesma largura. Já o nosso trabalho é um trabalho de artesão, um trabalho artesanal. E ai vem o espaçamento entre as plantas. $O$ espaçamento eu faço 3 filas de 3 e depois eu faço um buraquinhos no meio. $\dot{E}$ assim, por exemplo, eu uso uma técnica que é de consórcio, de misturar um tipo de planta com outro tipo de planta, para que? Para aumentar a produtividade da minha área. Como a minha área é muito pequena, eu quero aumentar a produtividade da minha área por metro quadrado. Como eu faço; eu ponho alface aqui, aqui, aqui, ponho nove pés de alface, e ai no meio eu coloco um repolho. Ai repolho, repolho, repolho. Ai a alface cresce, quando eu colho a alface, o repolho já está na mesma altura da alface, mas como ele tem um tempo maior de produtividade, então quando eu colho a alface, o repolho acaba de fechar. Fecha o canteiro. Então com isso, eu ganho 45, 50 dias do repolho. Dai com mais 30 dias, 35 eu colho o repolho; então isso aumenta minha produtividade, e com o mesmo manejo, com a mesma mão de obra, com a mesma adubação, mesmo canteiro, tudo. Então eu faço este tipo de coisas, ai tem outras coisas, por exemplo, o almeirão. Como ele exige menos espaço, o que que eu faço, ponho almeirão em tudo, nos 15 buraquinhos, em vez de eu colocar almeirão só nos 3 e por o repolho no meio, não, ponho almeirão em tudo. Cebolinha eu coloco em todos os buracos; salsinha em todos os buracos; os canteiros que são de salsa, salsa. Por exemplo, eu tiro a alface, depois eu tiro o repolho, ai eu planto salsa, então ai eu plantando nesses buraquinhos, eu coloco 3 mudinhas em cada buraco e ela cresce e fecha o canteiro e o plástico não vai deixar nascer mato. Só nasce o matinho, às vezes, no pezinho dela, mas é pouquinho e fácil de tirar. Então esses números aqui, são muito importantes.

Porque se você colocar 20 mudinhas de alface num metro, vamos supor que você coloque 15 em cada buraco o pé de alface vai ficar pequeno, ele vai se juntar e ficar pequeno. Vai se juntar e tampar a entrada de luz e pode dar fungos por baixo, porque não tem ventilação e ele pode apodrecer. Então para cada coisa, tem seu espaçamento, como o grupo e plantas que eu cultivo não dá para mim encaixar tudo nesta rede de buracos.

HOMEM: Esse plástico que você usa aí, è uma lona plástica preta?

G: É um plástico próprio para isso. De preferência o melhor que por cima ele é prateado e por baixo ele é preto. Tem um que é só preto, mas ele é de pior qualidade; estraga mais rápido pela ação da ultravioleta ele estraga muito mais rápido. Só que este outro plástico é muito mais caro, 3 vezes mais.

HOMEM: E o canteiro de alvenaria, numa horta pequena, que nem a dele assim...Fazer os canteiros, isso dá resultado ou não, tijolo, por exemplo? 
232

APENNDICE 20 - CONSIDERACÕES SOBRE A CONSTRUCÃO DE UMA HORTA ORGÂNICA NA ESCOLA FL. 7 de 9

G: Olha, depende, eu penso o seguinte, a minha horta tem $3.500 \mathrm{~m}$ de canteiro quadrado, se eu fosse fazer de alvenaria, eu teria que fazer $3.500 \mathrm{~m}$.

HOMEM: Mas isso não vai prejudicar a produção em si?

(G) Eu não sei, é porque esse dreno que você faz é para ter a drenagem, é para escoar a água Se você construir alguma coisa que drena bem, pode até ser. Como meu terreno é torto, e tem uns barrancos, penso em arrumar alguma coisa futuramente para escorar estes barrancos. Já pensei em chapa de off set, tem que ser alguma coisa barato, porque senão... Eu acho assim, que se você fizer um trabalhinho legal, mesmo só a terra com o tempo, que ela vai fazer. Ela vai criar aquelas camadinhas que em cima vai estar mais fofinha, mas para baixo ela vai estar mais firme. Mas se começar a desbarrancar, começar a ter este tipo de problema, você tem que arrumar uma forma. A alvenaria eu não sei; você teria que fazer um $U$ ou uma canaleta furada para a drenar bem. Tem que ser alguma coisa assim. Eu já pensei, sabe aquelas manilhas cortadas, que é usada para fazer escoamento de água, então de repente você achar numa largura ideal, que é cortadinha no meio, você pode colocar no fundo, mas eu não sei se vale o investimento. Para começar o vocês precisa e vocês precisa arar aquela terra certo, $\mathrm{e}$ como vocês vão arar? Vocês vão trazer um trator, eu acho que... não acho que vocês vão fazer na munheca antes de qualquer coisa precisa de ferramentas para as características de vocês. Vão precisa de enxadão, de enxadas, alguns rastelos assim, para um momento posterior por exemplo; se vocês plantando para capinar os canteiros depois vocês vão Ter que comprar umas enxadinhas pequenas. Uma coisa interessante, se vocês fizerem um programa legal de trabalho vocês podem levar pequenas turmas, se levar alunos de montão destrói a horta, mas se vocês organizarem pequenas grupos de ajuda vocês podem fazer toda a capina manual $E$ a intenção é de entrarem no processo que é uma coisa interessante e um bom laboratório. Ai vocês vão precisar arar. Se vocês conseguir alguma terra boa pode pedir para a prefeitura trazer uma terra que vocès poderia usar como e pouquinho coisa. Vocês podem, com carrinho de mão, vocês vão fazendo os canteiros joga aquela terra por cima Tem que ser uma terra escura que já vê que tem nutriente, mas se vocês não quiserem esse recurso pode ser descartado. Vocês podem trabalhar com a terra que vocês tem. Ta uma terra meio ressecada ta uma terra probiemática faz tempo que não cresse mato ali

(Violeta) mas como aqui o objetivo é didático, eu acredito que trabalhar com ela esta terra, o resultado é melhor a longo prazo logicamente

(Peri) Mas ainda tem aquela opção de ta recuperando uma parte ou talvez Ter uns canteiros iniciais para dar um reforço com uma terra melhor

(G) Isso ai e uma opção que vocês pode usar ou não então assim acho que todo trabalho de recuperação do solo vocès poderiam ir já fazendo em cima de canteiros. Como a área e uma área pequena, vocês alinham os canteiros, faz os canteiros. Não vejo necessidade de trabalhar em curva de nivel ali, então faz os canteiros retos mesmo a área e encilhada então o que vocês podem fazer, vocês podem trabalhar fazendo umas plataformas nos canteiros como uma escada assim, para superficie do canteiro. Vai ficar plana, vai ficar em nivel porque o que o pessoal faz por ai com o trator. Se a terra é inclinada assim os canteiros ficam todos tortos também, mas como e uma coisa artesanal manual, se a superficie do canteiro ficar retinha e melhor porque você não vai Ter problema com o escoamento da água. Ai você põe os nutriente ali você sabe que eles vão ficar e assim esse trabalho inicial quem vai fazer

(Peri) A idéia era o seguinte: haveria um grupo de professores, claro nós aqui escolhemos trabalhar com duas turmas de alunos. Escolhidos a dedo alunos que nos achamos que podem fazer um trabalho interessante. Conosco então nós contaria com esse grupo de professores. Cinco pessoas que somos nos aqui e digamos duas turmas num total de cada turma de 40 alunos, vocês vão precisa usar os 40 , mas seria esse pessoal que agente pudesse 
contar. Agora tem que ver se isso realmente e viável porque se não e nos vamos Ter que pensar uma outra estratégia

(G) pensando em termos práticos é um primeiro trabalho, vai ser quebrar no enxadão esse solo depois elaborar os canteiros. Coisa pratica mesmo da uma molhada antes Agora a terra já foi molhada, nos estamos com as ferramentas. Tá com tais pessoas, alem de nos precisariamos para fazer isto. Vamos supor que seja aquela área que você sugeriu atras da caixa d'agua. Na execução prática do trabalho eu tenho que ter uma equipe digamos de 4 a 5 pessoas que vão se revezando, mas sempre trabalhando no máximo 4 pessoas. Pôr exemplo 4 alunos e 1 professor e ai quando aquela turma tiver feito tudo o dele ai entra a outra turma, mas no máximo 4 pessoas.

(Flora) Porque também $G$, tem os problemas dos pais, não são todos os pais que vão concordar em dar uma enxadinha para o filho ficar cavando terra por ai.

(G) Vocês tem que tomar o cuidado de transformar isto numa coisa didática

(Peri) Por exemplo no dia que a Flora ou a Amélia estiver com a turma, com essas 2 turmas, vai ter que se montar uma tabela de escala. Ai uns 4 alunos vão trabalhar $x$ tempo, acabou a parte deles: outra turma entra e assim por diante. Mas o que a Amélia estava perguntando, e é uma preocupação nossa também $G$ é tipo assim: vão ser vários canteiros, teria possibilidade prática por exemplo de existir 2 turmas trabalhando ao mesmo tempo distante uma da outra?

(G) eu acho assim, o que vocês precisam estrutura. Vocês podem pegar uma faixa de 2 canteiros, ai quebra aquela faixa no enxadão ai depois o que você pode fazer, você pode montar aqueles canteiros, já deixa prontinho. Se não fica andando em cima, deixa prontinho a linha. Foro os canteiros, deixa pronto, ai o que você pode fazer você, pode Ter mais uma equipe quebrando onde vão ser mais dois canteiros e outra equipe já preparando aqueles quebrando os terrões, acertando, adubando e importante organizar o trabalho de jeito que as pessoas não fique andando. Não adianta você quebrar tudo de uma vês e fica todo mundo andando em cima. Inicialmente quebrasse tudo e afofasse a terra, ai enquanto uma turma continua a montar canteiros e tudo mais, num outro trecho passasse a ser afofado, então a gente não tem que pôr gente para fofar toda a área. Uma parte para poder fazer a coisa com escalas o problema nosso e usar um mecanismo que nos permita de manter todo o grupo de alunos direto ou indiretamente envolvido no projeto, que è por isto que a gente esta preocupado com esta questão de quantos, qual o numero de alunos que a gente vai envolver numa atividade $x$ ou y. Eu acho assim que a hora que vocês começarem isso, vocês vão descobrir os trilhos para isso. Vocês vão descobrir os caminhos, a forma. Você começa de um jeito e você percebe que não deu certo, vocês vão ter que mudar readaptar

(Discussão sobre número de canteiros possiveis na área escolhida)

(Peri) Deixa eu ver se entendi. Então vamos supor, vamos lá, molhamos a terra, ai inicialmente a gente pega um grupo de 4 alunos + 1 professor e fazemos o trabalho de afofar uma parte ai eles já afofaram aqui ai em quanto eles vão trabalhando os canteiros um outro grupo pouco distante prepara mais dois canteiros - depois eu coloco mais dois canteiros de forma que eu posa ir incluindo um numero incluindo cada vês + alunos mas com cuidado de que o trabalho de um não interfira no trabalho do outro e enquanto isto nos vamos fazendo acompanhamento em sala de aula em atividades paralelas .

(G) Uma coisa interessante é embasar essa parte com literatura, vocè pega um texto, ilustrações, vocès podem inventar nessa área, fazer visitas, se vocès quiserem um dia fazer uma visita lá em casa pode levar a molecada não tem problema 
(Peri) Então tudo bem afofamos a terra montamos os canteiros ai faz os canteiros com plástico faz os buraquinhos lá e ai pôr exemplo para agente decidir o que a gente vai plantar tem que fazer uma análise do solo

(G) Então e bom fazer tudo direito, fazer essa análise de solo que você pode fazer qualquer hora. A primeira providência, eu acho, é fazer a análise do solo, ir lá na casa de agricultura...

(Peri) Aí é que tá, análise do solo é o seguinte, primeiro vou na casa de agricultura, vou atrás do cara, mas o que que eu faço, eu faço, eu retiro uma amostragem, eu mesmo retiro e levo? Ou eu trago o cara para fazer aqui?

VITOR: Ou se convida o cara. Ele já se dispôs, vem aqui, vem falar um pouco da casa de agricultura.

(G) Supondo que a gente já fez a análise, ai que a gente vai definir os produtos? Vocês precisam de material. Deixa eu falar do que vocês precisam. Vocês vão precisar de ...a primeira coisa é o adubo, precisam de adubação, certo? O que que vocês vão comprar; como é uma terra que está aí.. largada, eu acho que vocès precisam de composto, de trabalhar com composto orgânico, invés de trabalhar com adubo de galinha, poderia trabalhar com composto, é fácil de comprar...tem várias lojas que tem composto orgânico.

(Peri) Então tá, nós vamos ter composto orgânico, mas se a gente considera aquela idéia de fazer, por exemplo, fazer uma coisa paralela; trabalhar de um lado com composto e de outro lado com adubo verde. Pode ser isto também, porque o que eu estava pensando é como a Amélia falou tornar as suas experiências visiveis para os alunos para que eles façam uma comparação, então para fazer o adubo verde, o procedimento é o mesmo. Afofa a terra ,muda os canteiros e taca o adubo verde lá, porque ai, eu posso por duas equipes já fazendo coisa diferentes, enquanto um grupo trabalha com adubagem outro grupo trabalha com composto .

(G) O que é interessante, é você, por exemplo, do jeito que esta ali e bom mesmo antes do adubo verde, você poderia chegar por exemplo nesta terra que está ai, você chega e joga o adubo verde ai e deixa brotar, certo, mas se você fizer os canteiros, você já prepara. os canteiros Fica mais didático, inclusive você vai ver os canteiros certinhos de cada coisa com adubo verde direito, você por fazer por exemplo, um canteiro de feijão de porco, um canteiro de mucuna, num canteiro você pode plantar feijão de porco e milheto por exemplo ou girassol você faz um canteiro de girassol e fica super bonito. Depois, irrigação vocès vão precisar. Como a horta e pequena, dê para você fazer até na mangueira, mas se você pensar numa coisa, como exemplo talvez seja interessante trabalhar uma irrigação, mas colocar lá um biquinho para girar . Irrigação é o seguinte, deixa eu falar para vocês sobre a irrigação. Tem aquela estória da irrigação e a molhação certo, se você comprar bicos que jogam 3.500 It de água por hora, isto é um absurdo, isso e absurdo em qualquer lugar, mas é o que as pessoas usam. Eu uso uns biquinhos israelenses, uns redondinhos assim, não sei se você chegou a ver tem um biquinho redondinho que tem que tem biquinho, que cada um é de uma cor. Ele é gordinho e tem um biquinho assim, ele joga $600 \mathrm{It}$ de água. Geralmente toda essa tecnologia vem de Israel eles são mais avançados nesta área. Então a minha sugestão e que se trabalhe com bicos pequenos.

FIM DA FITA 2 
APÊNDICE 21 - APRESENTAÇÕES DOS CURSISTAS SOBRE OS PROJETOS PROMOVIDOS FL. 1 de 5

ENCERRAMENTO DO CURSO - (15 ENCONTRO 27/11/1999)

EVENTO: EDUCAÇÃO E DESENVOLVIMENTO SUSTENTÁVEL EM IBIÚNA

TRANSCRIÇÃO DE FITA DE VÍDEO

\section{APRESENTACÃ̃O DO PROJETO: "HORTA ORGÂNICA"}

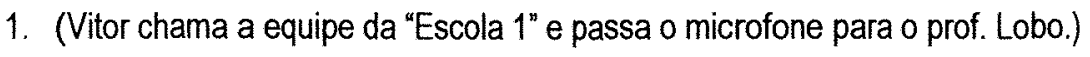

2. (Prof. Lobo) (...) Antes de freqüentarmos o curso, eu e a Profa. Flora nas reuniões, estávamos sempre comversando sobre elaboração de uma horta, já tínhamos a idéia. Só que não tinha este nome horta orgânica, talvez fosse mesmo uma horta convencional, não seil Ai apareceu o curso do Antonio Vitor e nos deu uma assessoria realmente muito importante para a escolha do "nome" do projeto, que ficou com o nome de Projeto Horta Orgânica. Foi o curso que realmente nos incentivou para a escolha do "nome" de horta orgânica.

3. No decorrer do processo, este projeto foi elaborado com várias etapas: a primeira etapa foi a preparação dos alunos teoricamente, utilizando textos e video; mostrando a agricultura convencional e a agricultura orgânica. Nós fomos fazer uma oficina prática na propriedade do $G$ que é um produtor orgânico no municipio, também para gente aprender, nós não somos agricultores certo?! Não conhecemos as técnicas agrícolas, tivemos que ir atrás de tudo isso ai. Esta foi a primeira etapa: parte teórica. Utilizamos vídeo e textos para tentar mostrar teoricamente a agricultura orgânica para os alunos.

4. Depois da primeira etapa iniciada, nós entramos na prática do projeto que foi o desenvolvimento da horta, com todos trabalhos que envolveram o surgimento da horta: preparação dos canteiros, adubação de vários tipos que necessitou, transplante das mudinhas, irrigação. Tudo isto ai de mostrar, acompanhar com relatórios, anotações e também continuava a parte teórica. Algumas coisas me marcaram neste projeto por exemplo: logo no inicio falaram é preciso colocar cadeado no portão se não o pessoal vai entrar, pisotear, tirar mudas, destruir, etc., mas alguém disse não dá para colocar cadeado pois o pessoal estraga o cadeado e não conseguiremos abrir a escola, então ficou o portão aberto. Mas não houve nenhuma destruição do pessoal dos arredores, então foi uma coisa muito importante isto ai.

5. Outra coisa que achamos muito importante foi que o terreno onde ficou localizado a horta, quando os alunos iam visitar ou trabalhar, nossa! Era um lugar que eles próprios pegavam os papéis, eles limpavam, eles tinham preocupação de passar pelo lugar certo de circulação. Uma coisa de respeito realmente. A gente tem esperança que este projeto reverta em relação à escola até,,, esse respeito pelo patrimônio da escola, pela limpeza, está abrindo um leque para várias coisas dentro da escola. Então isto foi uma das coisas positivas, muito positiva do projeto. A Flora tem outras coisas para contar, pois ela também vivenciou tudo isto aí.

6. (Prof. Flora) ...Eu gostaria de começar com a frase: "Tudo vale a pena se a alma não é pequena!" (..) Por que? Porque eu acreditei na $6^{\mathrm{a}} \mathrm{A}$, eles me deram um retomo fantástico, botei fé nestes alunos, eles trabalharam, uma coisa assim, eles incorporaram o projeto. 0 prof. Lobo colocou a parte técnica que trabalhamos a teoria aliada à pratica, etc... Mas é interessante porque aquele pedaço pequeno de terra existente na escola e que estava adormecido, de repente acordou e acordou de uma maneira fantástica gente, porque foi tão interessante, porque eu jamais plantei alguma coisa, eu até comentei com o Vitor quando teminamos o plantio eu fiquei tão assim... 


\section{APENDICE 21 - APRESENTACÕES DOS CURSISTAS SOBRE OS PROJETOS PROMOVIDOS FL. 2 de 5}

7. Eu não sei nem explicar, a energia era tão grande, porque eu percebi que existia laços de seres humanos fortes, de alunos que se equipararam a professores, se igualaram, onde todos eram iguais, não existia aquela diferença, professor, aluno, imposição, não. Nós lamos para a horta e eles eram capazes de sintonizar tudo, sem eu estar, porque na sala eles sabem como eu sou, de vez em quando eu dou uma chamada neles. $\mathrm{Na}$ horta acho que eles liberavam toda aquela angústia, aquele desespero que todo mundo atravessa hoje em dia; a terra nos acolheu de maneira super agradável; então havia assim,, um equilibrio em tudo, sem imposição.

8. Eu gosto de citar esta parte, uma experiência que é muito interessante: quando fomos preparar os canteiros, então nós tínhamos a bandeja, estávamos numa turma, sem eu falar nada, um ficou segurando a bandeja e, sem imposição nenhuma, automaticamente, vinham os outros passando as mudas e outros iam replantando. (...) Depois de um certo tempo observando eu falei: "meu-deus que coisa mais linda ver estes alunos estarem fazendo e se ajudando". Então o que isto pode estar demonstrando: que existe relacionamento entre seres humanos, que ainda dá para acreditar que aluno e professor precisam um do outro, que eu não preciso falar por favor prestem atenção no que estou dizendo, pois eles já estavam prestando.

9. Outra coisa, parecia que a terra nos chamava, pedia que estivéssemos o tempo todo cuidando dela. Então vocês podem achar exagero de nossa parte, mas eu considero a horta um lugar sagrado, um lugar sagrado sim porque nos deu muito conforto, ela nos acolhe nos momentos de desespero, porque nós temos problemas de comportamento. Mudança de comportamento de aluno aconteceu? Aconteceu muito, tinha alunos que estavam de castigo por causa de outras coisas e eles queriam ir para a horta gente!, porque lá eles trabalhavam, eles se mostravam.

10. O que posso dizer para vocês é que houve uma retenção muito importante; (...) houve retenção dos nossos valores. Para eu este trabalho foi,,, está sendo,, Eu não tenho,,, Eu não posso,,, eu não con-sigo,,, estou emocionada porque eu acreditei, sonhei e o sonho foi realizado. Eu só posso parabenizar o Vitor e a Cidinha por ter nos proporcionado tudo isto. E gostaria de trazer os responsáveis para vocês verem os rostinhos deles, porque eu tenho a minha turminha que trabalhou pesado.

11. (A professora vai chamando os alunos, apresentando-os e fazendo um comentário para cada um. No total foram 8 estudantes, entre as apresentações a professora declara:)

12. (ProfaFlora) (...) É tão importante para eu trazer e abraçar um aluno e acreditar que uma escola estadual conseguiu realizar uma porção de coisas boas. (Palmas)

13. (Uma aluna é convidada a falar)

14. (Aluna M.José) Foi uma grande experiência para gente, eu praticamente já sabia lidar com estas coisas por causa do meus pais, mas os meus colegas puderam aprender mais sobre o nosso projeto... horta orgânica. $E$ neste periodo é bom que a gente está mostrando p'ra todos que a gente pode continuar, e que de uma certa forma eles também podem fazer isto e não é dificil basta você querer. Mas eu sei também que o mundo lá fora está cheio de gente que não reconhece isto. Mas este mundo vai rolar. O importante é que o mundo agradece, a quem faz o melhor para ele, amanhã ... e depois aproveita os resultado com o passar do tempo.

15. Foi realmente maravilhoso estar trabalhando lá, a gente se orgulha vai lá e diz: nós conseguimos, nós fez; acho que não tem coisa melhor, eu mesmo ... foi super dez (risadas dos participantes) é super dez, dez mesmo pessoal. Obrigado a todos e pretendo continuar, nós começamos, isto é o começo de tudo, mostran- 
APENDICE 21 - APRESENTACÕES DOS CURSISTAS SORRE OS PROJETOS PROMOVIDOS FL. 3 de 5

do p'ra todo mundo que é possivel produzir uma coisa boa, de maneira saudável, sem uso de produtos "tóchicos" (um professor corrige em voz baixa e a aluna repete:) tóxicos. (palmas)

16. (Palmas. Outro aluno é chamado para falar)

17. (Aluno David) Este projeto além de ensinar, ele está trazendo,... trazendo mais interesse pelos alunos, esse projeto,,, é uma maneira prática.... (aluno emocionado e nervoso, não consegue continuar falando, a professora Flora intervém e explica:)

18. (Prof Flora) É que nos temos um probleminha sério de sensibilidade (abraçando o aluno), eu e David trabalhamos numa parte muito boa que é a mudança de comportamento dele e minha e a interação dele dentro da sala de aula e então nós estamos assim emocionados!

19. (Dois alunos falam agradecendo e lembrando todos os professores que participaram do projeto.)

20. (Coordenador Peri)E u acho que não tem o que acrescentar ao que foi falado por nossos alunos, ao Lobo, à Flora. A reação dos alunos já mostra muita coisa para vocês. Eu só queria dizer que quando o projeto começou nós achávamos que ele era muito interessante, afinal de contas lbiúna é uma cidade agricola, isto é uma coisa que vem sendo perdida aos poucos em função de todos os problemas que a cidade vem passando, e a questão ambiental que não podia deixar de ser discutida.

21. Agora, desde o início o grande eixo deste projeto foi a questão comportamental. É uma preocupação da coordenação e a direção da escola a questão do comportamento cada vez mais agressivo que a gente registra, o que não é segredo nem na nossa e nem em qualquer outra escola aqui presente. (...) Quando a Flora levantou o projeto, nós pensamos muito quem colocariamos no projeto, havia medo de vandalismo, medo de destruição, claro eu tinha receio. Agora acho que mais que ver a horta produzir, num terreno que era resto de entulhos, reformas e tudo mais, é justamente ver este processo de construção de relacionamento entre os próprios alunos e entre os alunos e professores.

22. É claro que temos muito que avançar ainda, mas eu acho que foi muito significativo o que a gente já avançou. Só queria enfatizar também que muitos professores foram essenciais ao projeto e que não estão aqui presente, como é o caso do prof. Figueira e do prof. Toninho. (...) É claro que a gente não sabe o que vai acontecer no ano que vem com o projeto, teremos que fazer um plano de emergência para as férias, mas a idéia é ampliar este projeto da horta e construir outros projetos como este, que não só ensine educação ambiental mas que também crie condições para mudar a qualidade de relacionamento que existe na escola entre alunos e professores, é um processo de anos mas acho que o que conseguimos nestes quatro ou cinco meses na escola foi muito significativo realmente.

23. (Vitor expressa algumas questões de encaminhamento e relata um fato que observou, na Escola 1.)

24. (Vitor) Esta semana eu fui lá, (...) enquanto estacionava o meu carro observei (...) tinha duas senhoras passando em frente à escola, elas atravesFloram a rua e foram até o portão (...) para ver aquele movimento (...). Isto tem acontecido freqüentemente.

25. (Profa Flora) É! ...

26. (Vitor) Tem vizinhos que não são da escola mas ...

27. (Prof.Flora, interrompendo e completando a frase) Eles olham a horta, né Peri ?

28. (Prof. Parreira) (...) Eu gostaria de saber, assim, com relação ao apoio. Vocês tiveram bastante apoio? 
APENDICE 21 - APRESENTACÕES DOS CURSISTAS SOBRE OS PROJETOS PROMOVIDOS FL. 4 de 5

29. (Prof Flora) Bem lembrado. Com nossa direção, nós temos uma felicidade muito grande porque eles nos dão abertura. Nosso coordenador aqui é fora de série. (???) Apoio tivemos assim: nós arregaçamos as mangas e fomos à luta, sem muito material, sem doação de terra (...) foi com a nossa terra mesmo, e é tão interessante porque a terra, a tal mãe terra mesmo, aquela mãe, nos acolheu de tal maneira que conseguimos produzir naquela terra ali.(..) Tivemos alguns problemas, né Peri?

30. (Coordenador Peri) É tivemos algumas dificuldades administrativa. Era dificil contemporizar o trabalho do professor em sala de aula com a questão de ter que estar com um grupo de alunos fora da sala enquanto o restante dos alunos permaneciam. (...) A idéia inicial era preparar uma área muito maior, nós pretendíamos uma terra de boa qualidade, (...), mas houve algumas dificuldades, até porque esta parte ficou mais comigo e a coordenação tinha vários outros projetos em andamento e eu não pude dar à horta o tempo que o projeto merecia no meu entender. Então durante agosto e setembro as coisas caminharam com uma certa lentidão.

31. Então o Figueira, o Lobo e a Flora disseram o negócio é o seguinte: nós não temos área privilegiada então vai esta comum. Porque o terreno da Escola é basicamente um morro, então todos os lugares eram um decli$v e,(\ldots)$ e os alunos trabalharam, tiraram até concreto, porque houve muitas reformas naquela área e acabou saindo. Até ficou interessante porque virou um experimento, era uma área pequena e serviu como laboratório mesmo. Houve dificuldade. Agora da parte do corpo discente e aqui nós temos alguns alunos da turma que trabalhou diretamente, a gente percebe algo muito significativo, nem os alunos das outras séries, nem os alunos do noturno,,, todo mundo de alguma forma procura garantir a manutenção, a integridade daquela área, então houve realmente uma participação coesa da escola como um todo e entraves maiores não aconteceram.

32. (Prof.Cameiro) Eu gostaria de perguntar para os alunos se: vocês estão comentando este trabalho com os pais, com os colegas? Se vocês convidam para ver? Se vocês estão fazendo isto em casa?

33. (Aluna Violeta) Eu mesmo praticamente eu comento quase tudo com meus pai, para eles não é novidade, porque é praticamente é o que eles fazem, lá na minha casa tem quintal, tem plantação, tem tudo mas eles acham importante é tá passando este conhecimento para os outros alunos que não têm.

34. (Prof. Flora) Viu Cameiro completando sua pergunta, (...) nós temos um aluno que estava com problema de comportamento e a mãe nós procurou e disse o seguinte que gostaria de estar ajudando a fazer este trabalho de horta, então nós estamos conseguindo trazer os pais, no caso desta mãe ela mandou algumas mudas. (...) E a comunidade tem... Vou contar uma experiência, nós estávamos preparando a horta e apareceu um menino que não é aluno, ficou encostado, olhando, e olhando. Ai eu precisava buscar um material junto com o Figueira (...) O moço se falou: '-Ah, se a senhora quiser eu vou junto! '-Mas você não é nem aluno!' '-Mas eu quero!'. E foi, e carregou saco com serragem. (...)

35. É por isso que eu falo que ali é um lugar sagrado, é que a terra tem uma energia fora de série, não sei o que é, pois eu não sou Deus, nem ninguém para falar, mas eu sinto que quando eu estou no meu desespero, na minha angústia, e parece que toda a aflição destas crianças (apontando para os estudantes que estão ao seu lado) a terra acolheu e trouxe uma energia positiva para o Roque Bastos (Escola1). Parece que o Roque Bastos depois da horta trouxe muita energia, parece que as plantas olharam para a gente: Bom dia! Chegaram! Vocês estão ai. É muito interessante o trabalho.

36. (Daiana - aluna da Escola 3) Eu queria dar parabéns para vocês, pelos resultados que teve melhorou a atitude dos alunos, como a professora disse aqueles alunos com mau comportamento agora melhoraram (...), eu queria que isto fosse repetido não só no Roque Bastos, como nas outras escolas, por exemplo eu sou da 


\section{APÊNDICE 21 - APRESENTACÕES DOS CURSISTAS SOBRE OS PROJETOS PROMOVIDOS FL.5 de 5}

Escola Laurinda, queria que os alunos tivessem o mesmo (???) que vocês tiveram, (...) toda escola tem seus alunos bagunceiros e como você mesmo disse isto mudou, mudou para melhor (som muito baixo e com ruidos, transcrição dificil).

37. (Coordenador Peri) Eu só queria dizer uma coisa: é claro que não é tudo maravilha, quem é hoje professor ou aluno sabe que a vivência dentro de uma escola estadual é um processo dificil. Se eu dissesse para vocês conseguimos resolver todos os nossos problemas é obvio que não, mesmo o processo da horta é marcado por avanços e retrocessos, o relacionamento entre alunos e professores ainda tem muito que avançar mas, levando em conta todas as dificuldades que enfrentamos, eu acho que houve realmente progresso, tem muito que fazer ainda mas nós vamos (...).

38. PROJETO: "VALORIZANDO AS ÁRVORES EM NOSSO MUNICIPIO" (Trechos selecionados)

39. (Prof. Violeta) Uma experiência que me marcou muito e que eu não conversei com os meus colegas, deixei para registrar aqui,,, é quanto mudança no comportamento, relacionamento entre alunos e professor e é uma experiência própria, minha. Eu trabalho com uma das classes do $1^{\circ} \mathrm{colegial}$ da tarde e meu relacionamento com este pessoal era um relacionamento muito dificil. Mas que melhorou, como se fosse da água para o vinho, a partir de uma tarde que eu sai com esses alunos para regar as plantinhas que tinham sido colocadas na escola, a partir deste dia o meu entendimento com esta classe foi assim...,

40. Eu tinha muita dificuldade, que eles me atendesse, eles agrediam os móveis, escreviam, pichavam. Um dia na minha aula eu tive que parar, pedir para um aluno sair e buscar material para limpar, não que eu tivesse falado asperamente(...) não era uma agressão para com a escola mas para com a minha pessoa, porque ali na minha frente ele tirava o pincel atômico e pichava a carteira. Então delicadamente eu precisei parar a aula e por favor vá até a pessoa da limpeza, pegue álcool e pano para a limpeza, eles nunca me responderam. Mas a partir deste dia que nós saimos juntos, fomos buscar instrumentos para regar aquelas pequenas mudas, eu não precisei falar nenhuma palavra, foi apenas um trabalho de regarmos juntos... aquelas mudas, $o$ relacionamento humano com esta classe mudou completamente. Isto eu queria deixar registrado, que realmente como a Flora colocou, que este trabalho diferente que estamos fazendo, só por isto ele já valeu.

41. (Prof.Ceci) Outra coisa que eu gostaria de incluir, acrescentando ao que a dona Violeta disse e que eu acho que de modo geral os outros colegas são testemunhas disto: 0 relacionamento entre todos os professores das várias escolas durante este curso, também foi muito importante porque ele foi ampliado, agora não somos mais colegas de trabalho atuando uma escola, nós somos amigos. Eu acho que isto também começou no curso e foi se estendendo em todas as atividades em todos projetos: uma melhoria na relação humana, isto eu acho o bem de maior valor.

\section{FIM DA TRANSCRIÇÃO}




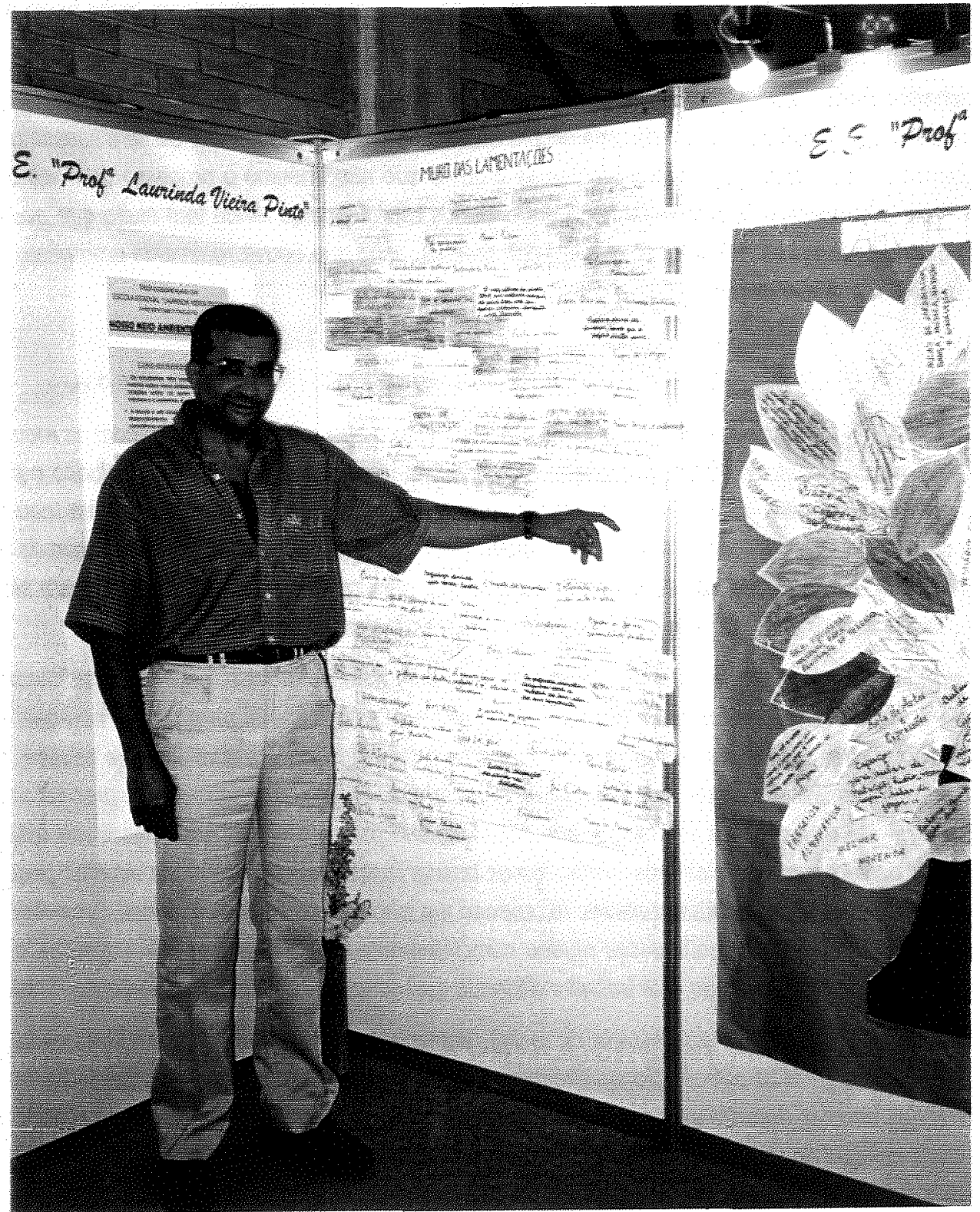

Professor, membro da Equipe 3, mostrando o "Muro das Lamentações" (acima) , o "Muro das Alegrias" (em baixo) e parte da "Árvore da Esperança". Estes trabalhos foram gerados pelos estudantes da Escola 3 como parte do exercicio de produção da Agenda XXI da Escola no contexto do Projeto " Nosso Meio Ambiente Escolar" 


\section{APENNDICE 23 - EXEMPLO DE PROPOSTA DE PROJETOS EDUCACIONAIS FL. 1 de 2}

Projeto educacional Idealizado e promovido pela Equipe de cursistas educadores da Escola Estadual "2" (Ibiúna), apoiado pelos demais professores e funcionários, com autorização da Diretoria da Escola.

\section{"VALORIZANDO AS ÁRVORES EM NOSSO MUNICÍPIO"}

\section{OBJETIVOS GERAIS}

- Mudar o entendimento e o comportamento dos educandos em relação ao meio ambiente;

- Motivar os educandos no sentido de se comprometerem com o enfrentamento de problemas ambientais, a partir do entendimento de suas responsabilidades (individuais e coletivas) com a questão;

- Incentivar os educandos para que incorporem o sentimento de pertencimento à comunidade e o desejo de participação social;

- Desenvolver atividades educacionais no espaço exterior a escola, através de ações práticas.

\section{OBJETIVO ESPECÍFCO}

Desenvolver o componente educacional de um programa de valorização e incentivo ao plantio de árvores em zonas urbanas e rurais, incluindo:

- Sensibilização dos educandos e comunidade quantos as questões ambientais, em especial a importância das árvores para o meio ambiente e para qualidade de vida.

- Disponibilização de informações sobre a importância ambiental do municipio de lbiúna, considerando sua localização (proximidade da Região Metropolitana de São Paulo), seus aspectos ambientais relevantes (ex.: ocorrência de diversos fragmentos florestais em especial o Parque Estadual do Jurupará e limite com a Reserva Florestal de Morro Grande) e suas atividades econômicas (agricultura e chácaras de passeio).

- Envolvimento dos educandos (e da comunidade) em atividades de plantio e manutenção de árvores na cidade e no campo;

\section{JUSTIFCATIVAS}

O grupo avalia que há uma série de aspectos que justificam a necessidade e a validade de um projeto como este, destacam-se:

- Grande desconhecimento em relação à fauna e flora regional.

$\checkmark$ Distanciamento das pessoas em relação à natureza (não transformada).

- Desvalorização e desconsideração quanto à praticas de conservação ambiental, implicando no uso dos recursos naturais como se fossem infinitos.

$\checkmark$ Poucos nativos reconhecem a importância ambiental da região e seus recursos.

- A Escola é um excelente espaço para a educação ambiental, sendo o meio ambiente um dos temas transversais propostos nos P.C.N.s.

$\checkmark$ Especificamente nesta U.E. há um grupo de educadores que já trabalham alguns aspectos ambientais da região.

$\checkmark$ Existe entre os integrantes do grupo uma vontade de desenvolver ações de educação ambiental com os estudantes e com a comunidade. 
APENDICE 23 - EXEMPLO DE PROPOSTA DE PROJETOS EDUCACIONAIS FL. 2 de 2

\section{METODOLOGIA E PROCEDIMENTOS}

- Os professores trabalharão os "conteúdos" de maneira interdisciplinar.

- Os alunos desenvolverão ações práticas junto à comunidade, através de pesquisas e trabalhos individuais e em grupos;

- Serão promovidas oficinas de produção de mudas e de "manutenção" de árvores;

- Promover atividades para a sensibilização tais como: dinâmicas de grupo, apresentação de vídeos, leituras de textos, etc;

- Realizar visitas monitoradas e, na medida do possivel, desenvolver um programa de acompanhamento em viveiros de produção de mudas;

- Desenvolver pesquisas de campo em regiões preservadas através de excursões monitoradas;

- Elaborar um catalogo para identificação de algumas espécies nativas possiveis de serem plantadas. 0 catálogo deve incluir caracteristicas como: floração, tipo de raiz, alimento para pássaros ou outros animais, altura média, comportamento das folhas, etc:;

- Promover uma campanha de plantio e preservação de árvores nas zonas urbanas e rurais;

- Buscar parcerias com setores da Prefeitura Municipal de lbiúna (meio ambiente, educação, agricultura, etc.) visando: fornecimento de mudas das espécies a serem plantadas, promoção de transporte para trabalhos de campo, viabilização da construção de um pequeno viveiro de mudas; aquisição de materiais de consulta para a biblioteca municipal, e principalmente apoio à campanha de plantio;

- Buscar o máximo envolvimento possivel dos segmentos escolares (direção, funcionánios, professores e alunos) e da comunidade que se relaciona com a escola (parentes, vizinhos e outros interessados);

\section{MATERIAIS E RECURSOS}

Pequeno viveiro e recursos para seu funcionamento;

Mudas de espécies nativas;

Protetores de mudas;

Transporte para trabalhos de campo;

Material de impressão;

Palestrantes;

Monitores;

Especialistas em educação ambiental e em produção florestal para apoiar o detalhamento e acompanhar 0 desenvolvimento do projeto;

Coordenadores de atividades;

Professores;

\section{CRONOGRAMA}

As atividades ocorrerão a partir do $2^{\mathrm{a}}$ semestre de 1999 (programação a detalhar) 
APÊNDICE 25 - TABULAÇĀo dE QUESTIONÁRIOS APLICADOS DURANTE A PALESTRA INICIAL FL. 1 de 2

QUESTIONÁRIOS RESPONDIDOS POR 16 EDUCADORES QUE POSTERIORMENTE TORNARAM-SE CURSISTAS.

$P E S Q Q U$ I S A

"O ENSINO DAS RELACŌES ENTRE MEIO AMBIENTE E AGRICULTURA"

\author{
Meu nome é \\ Atualmente estou lecionando a(s) disciplina(s):
Biologia $3 \quad$ Biologia e Matemática 2 Biologia e Saúde pública 1
Geografia 4 História 2 \\ Matemática $3 \quad$ Educação Física 1 \\ nas escolas: Escola $1=4$ (Ibiúna) apenas ensino médio: 7 \\ Escola $2=7$ (Ibiúna) ensino médio e ensino fundamental: 9 \\ Escola $3=3$ (Ibiúna) \\ Escola $4=1$ (São Roque) \\ Escola $5=1$ (São Roque)
}

Considero meu grau de conhecimento sobre o assunto que envolve: "as relacóes entre meio ambiente e aquiautura":

muito pequeno [ ] pequeno [19\%] médio [81\%] grande [ ] muito grande [ ]

Meus conhecimentos sobre este assunto deve-se a: (identificar os principais $-1^{\circ}, 2^{\circ}, 3^{\circ} \ldots$ )

9 educadores classificaram suas opçöes $\left(1^{\circ}, 2^{\circ}, 3^{\circ}\right)$; 10 identificaram suas opçöes com " $x^{\prime \prime} \quad 1$ professor não respondeu faculdade [31\%] vivência no meio rural [38\%] experiência escolar [31\%] livros [ $88 \%$ ] tv [56\%]

Outras: Pesquisas [6\%] Encontro de Meio Ambiente [6\%] Revistas [6\%]

Considerando meus conhecimentos, a realidade brasileira especialmente a realidade da nossa regiāo e dos nossos alunos, acho que 0 assunto acima é:

irrelevante [ ] pouco relevante [ ] importante [19\%] muito importante [81\%]

Quanto à necessidade de tratamento desse assunto em uma ou mais disciplinas do ensino médio considero:

desnecessário [ ] pouco necessário [ ] necessário [50\%] muito necessário [50\%]

Obs.: 2 pessoas que responderam que o tema é importante responderam que seu ensino é muito necessário

enquanto que 5 pessoas que responderam que o tema é muito importante consideram que seu ensino é necessário.

0 tratamento deste assunto especificamente na minha disciplina me parece:

apropriado [ 88\%] parcialmente apropriado [13\%] não apropriado [ ]

Quanto as condições de tratamento desse assunto na minha disciplina considero:

fácil [38\%] relativamente fácil [56\%] dificil [6\%] muito dificil [ ]

Atualmente meu interesse em trabalhar este assunto em minha disciplina é

muito pequeno [ ] pequeno [ ] médio [19\%] grande [38\%] muito grande [44\%]

Meu desejo de aprofundar conhecimentos e discussōes sobre o assunto é:

muito pequeno [ ] pequeno [ ] médio [6\%] grande [56\%] muito grande [38\%]

Meu interesse sobre este assunto se deve a: (numerar $1^{\circ}, 2,3^{\circ} \ldots$ )

interesse como professor [ 19] interesse em educação ambiental [ 19] interesse sobre meio ambiente[ $3^{\circ}$ ]

interesse em questöes rurais [ $4^{\circ}$ ] curiosidade[ $5^{\circ}$ ]

(06s:Praticamente as 3 primeiras opçôes empataram com uma freqüência de escolha bem maior que as demais.)

O contato direto que tive com atividades rurais ocorreu: (Obs.: Algumas pessoas escolheram mais que uma resposta.)

como morador(a) [4]

como proprietário(a) [ ]

através de constantes visitas a zonas rurais [25\%]

como trabalhador(a) [6\%]

através de uma ou elgumas visitas a zonas rurais [44\%]

apenas como consumidor de produtos agricolas [ $44 \%$ ] 


\section{APÊNDICE 25 - TABULACÃO DE QUESTIONÁRIOS APLICADOS DURANTE A PALESTRA INICIAL FL. 2 de 2}

Meus conhecimentos sobre agricultura altemativa, orgânica ou agroecológica são:

inexistentes [ ] pouquissimos [19\%] poucos [25\%] médios [56\%] muitos [ ]

Você tem alguma experiência no ensino de relações entre agricultura e meio ambiente? Não [69\%] Sim [ 31\%]

Organização de uma exposição ecológica [ 2 pessoas]

Contatos com a Casa de Agricultura do município

Discussões com colegas

Considero meu grau de conhecimento sobre as questóes ambientais em geral:

nenhum[ ] muito pequeno[ ] pequeno[ 19\%] médio[69\%] grande[13\%] muito grande[ ]

Quanto à educação ambiental considero meu grau de conhecimento:

nenhum[ ] muito pequeno[ ] pequeno[ 19\%] médio[69\%] grande[13\%] muito grande[ ]

Quanto à minha experiência em atividades de educação ambiental, considero-a:

nenhuma[ ] muito pequena[ $6 \%$ ] pequena[ $44 \%$ ] média[ $50 \%]$ grande [ ] muito grande[ ]

Levando em conta apenas as atribuiçöes de professor(a) creio que meus conhecimentos e experiências sobre meio ambiente e sobre educação ambiental são:

desnecessários[] insuficientes[37\%] parcialmente suficientes[50\%] plenamente suficientes[ $13 \%$ ]

Em poucas palavras o que você entende por educação ambiental?

Qual a relaçäo que você "vê" entre sua disciplina, o mejo ambiente e a educaçäo ambiental?

Quanto à possibilidade de ampliar meus conhecimentos e experiências sobre meio ambiente e sobre educação ambiental diria que estou: sem interesse atualmente[ ]

um pouco interessado [6\%] interessado mas não priorizando [] interessado e priorizando [94\%]

Você já participou de projetos multidisciplinares em alguma escola? Sim[50\%] Não[44\%] Não respondeu[6\%]

(Caso afirmativo explique rapidamente como foi e qual a sua impressão)

Poucos explicaram o iniciativa Quanto às impressões foram divididas igualmente entre positivas e negativa

O que você acha sobre o desenvolvimento futuro de projetos multidisciplinares na sua escola ? (importancia, interesse, sonhos, dificuldades, condiçōes, parceiros, etc.)

O que motivou você a participar deste evento? (explique)

Anseio por ampliar os conhecimentos sobre o tema e sobre meio ambiente [ $50 \%$ ]

Interesse pelo tema [19\%]

Interesse em educação ambiental [6\%]

Anseio de ampliar a experiência com o tema [ $6 \%$ ]

Necessidade de reciclagem de conhecimentos [6\%]

Você é associado ou participa de alguma entidade (APM, sindicato, grupo ecológico, associações de moradores ou outros)? Qual? Por quê??

Não participa de nenhuma entidade [ $38 \%$ ]...

Participa/associado da Apeoesp [38\%]

Participa da APM [13\%]

Participa do Partido Verde [ $6 \%$ ]

Não participa de nenhuma entidade mas gostaria muito [ $6 \%$ ]

(ATENČ̃̃O responder ao final das atividades)

Escreva sua impressão em relação à proposta de curso-oficina apresentada.

Interessante (3) Importante (3) Ótima (3) Boa (2) Gostei

Muito Boa Gerou Expectativa Gerou Entusiasmo Estimulante: Envolvente 
APÊNDICE 26 - RETROSPECTIVA DO CURSO-OFICINA - A VISÃO DE UMA PARTICIPANTE

Muito diferente dos demais cursos que fiz até então, pela D.E. de São Roque, cativoume ao longo do ano. Tive a oportunidade de conhecer vários professores de alto nível. Muitos dos encontros trouxeram-me conhecimentos novos que, vieram preencher lacunas, provocaram mudanças de postura. Surgiu um novo conceito de educação ambiental, que seria vivenciado com os educandos, muito diferente do que eu fazia.

Terminado o curso, sentimos que fizemos muito pouco com os alunos, pelo tanto que recebemos e pretendiamos fazer no ano em curso, fica assim, um compromisso a ser cumprido nas nossa atividades diárias.

Um dos aspectos que me tocou profundamente é a amorosidade que emanava dos mestres. Sentí que os profissionais que abraçam realmente as causas ambientais tem o cotidiano construido pelo laço do amor que une incondicionalmente todos os seres e o ambiente fisico.

Esta emanação amorosa dos mestres conseguiu unir, nós professores em curso, fazendo nascer um compromisso reciproco para as causas ambientais, e como seres humanos, um laço mais sincero, sólido, amoroso e solidário entre colegas professores. Todos os cursos de extensão universitária são apenas técnicos, dai eu ter notado a diferença. Será que sou eu ,que pela primeira vez estou percebendo agora os fatos que sempre estiveram presentes?

Analisando os professores, ficou marcante na minha memória o Prof. Antonio Vítor Rosa pela sua paciência, dedicação, organização, determinação, empenho e simpatia. Acompanhou e encorajou-nos para enfrentar dificuldades e proporcionar novas experiências aos professores que são velhos no ramo mas muito coagidos e medrosos. O Professor Marcos Sorrentino, calmo, observador, que mesmo num encontro rápido transmitiu-nos segurança, doçura, e que o mais importante é a conscientização, pois este conduz à ação. Por menor que seja, a ação é mais importante que os devaneios mentais, portanto a educação ambiental deve ser vivida pelo educando para que haja conscientização. A Professora Ondalva Serrano, chamando- nos para exercer a ética e a cidadania com amorosidade, acordando-nos para uma espiritualidade que conduz ao desenvolvimento da intuição, aumentando a capacidade criadora, gerando um campo mental de alta energia. O paisagista Sr. Piter, sua simplicidade, conhecimento e a doçura com que dialoga com as plantas, evidencia a valorização da harmonia e beleza da natureza viva que nos rodeia. O agricultor, Sr. Geraldo, que abandonou a carreira de biblioteconomista na universidade e dedica ao modelo de agricultura orgânica auto-sustentável, defendendo a qualidade de viva humana. Um modelo de agricultura que luta em prol da saúde e longevidade do Planeta Terra pela manutenção da qualidade do solo e água.. O médico homeopata Fernando Bignardi que ensina buscar a essência do ser humano, ativando os sentidos, vivendo a real necessidade do ser humano pela unidade corpo físico e alma, evitando assim as doenças que afligem o homem moderno. Foi, com as orientações dele que superei, sem muita depressão, a noticia do adenocarcinoma seguida de histerectomia total.

Nessa rápida retrospectiva, creio ter conseguido, registrar a minha satisfação em ter sido contemplada nesse curso. Adquiri conhecimentos novos, fiz novas amizades, reforcei as velhas amizades, mas o que mais me felicita é que aprendi exercitar a amorosidade no convívio com alunos, colegas de trabalho e com a natureza que nos alimenta e nos mantém vivos. Fica também registrado, mesmo que modesta, o meu compromisso de empenhar-me como educadora, para as causas ambientais.

Finalizo, agradecendo a ATP da Diretoria de Ensino de São Roque, Professora Aparecida, que formalizou para a regularização do curso, aos agricultores que nos deram o seu precioso tempo para nos atender, a todos os professores, colegas do curso, direção das escolas que nos acolheu, e em especial ao professor Antonio Vítor pela incansável dedicação. Muito obrigada. 
APÊNDICE 27 - PARECER DA SECRETARIA DE ESTADO DA EDUCACÃO SOBRE O CURSO-OFICINA

GOVERNO DO ESTADO DE SÄO PAULO SECRETARIA DE ESTADO DA EDUCAÇÃO

COORDENADORIA DE ESTUDOS E NORMAS PEDAGÓGICAS

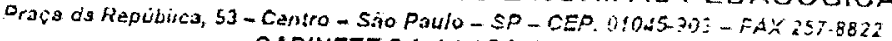
GABINETE DA COORDENADORA

Protocolo $n^{\circ} \quad 159-\mathrm{C}$

CURSO: As relaçoes entre a Agricultura o o meio ambiente, no âmbito do Ensino Médio, através da Educaçăo Ambiental.

INTERESSADO: DE Săo Roque

FONE: 425-3667/2522 FAX $425-2066 / 3667$

E-MAIL:

PARECER

Após a análise do relatório final enviado pela Diretoria de Ensino sobre a curso em questáo desenvolvido em trés inódulos, manifestamos como segue.

A Supervisora o a ATP manifestaram uma avaliação excelente do curso;

A avaliaçăo dos participantes sobre o curso foi satisfatória quanto aos conteúdos e atividados desenvolvidos;

- O uso do modelo proposto centrado na açao-reflexăo-ação, resultou em projetos vivenciados pelos cursistas e seus alunos na escola;

- Foi avaliado positivamente o desempenho dos docentes:

- Houve atendimento e acompanhamento da Oficina Pedagógica e da Supervisåo, demonstrando assim boa integraçáo no curso proposto, promovendo inclusive a divulgaçăo dos projetos elaborados alravés de encontros $\theta$ eventos regionais;

- Os participantes tiveram a oportunidade de adquirir uma visazo conceitual mais abrangente da Educação Ambiental, sobretudo quanto ao tratamento interdisciplinar utilizado.

- Goslariamos de ressaltar a importancia da DE em incentivar as escolas a incorporarem na proposta pedagógica aqueles projelos já vivenciados, assegurando dessa forma a sua continuidade e aperfeiçoamento

Isto posto, somos pela Homologaçăo do presente curso.

Săo Paulo, 06 de Janeiro de 2000

Marlene Gardel 


\section{APENDICE 28 - EXEMPLO DE PROPOSTA DE PROJETOS EDUCACIONAIS FL.. 1 de 2}

\section{PROJETO EDUCACIONAL: "VALORIZANDO AS ÁRVORES EM NOSSO MUNICÍPIO"}

Idealizado e desenvolvido por um grupo de educadores da Escola Estadual "Dois" (Ibiúna), apoiado pelos demais professores e funcionários, com autorização da Diretoria da Escola.

\section{OBJETIVOS GERAIS}

- Mudar o entendimento e o comportamento dos educandos em relação ao meio ambiente;

- Motivar os educandos no sentido de se comprometerem com o enfrentamento de problemas ambientais, a partir do entendimento de suas responsabilidades (individuais e coletivas) com a questão;

- Incentivar os educandos para que incorporem o sentimento de pertencimento à comunidade e o desejo de participação social;

- Desenvolver atividades educacionais no espaço exterior a escola, através de ações práticas.

\section{OBJETIVO ESPECIFICO}

Desenvolver o componente educacional de um programa de valorização e incentivo ao plantio de árvores em zonas urbanas e rurais, incluindo:

- Sensibilização dos educandos e comunidade quantos as questões ambientais, em especial a importância das árvores para o meio ambiente e para qualidade de vida.

- Disponibilização de informações sobre a importância ambiental do município de lbiúna, considerando sua localização (proximidade da Região Metropolitana de São Paulo), seus aspectos ambientais relevantes (ex.: ocorrência de diversos fragmentos florestais em especial o Parque Estadual do Jurupará e limite com a Reserva Florestal de Morro Grande) e suas atividades econômicas (agricultura e chácaras de passeio).

- Envolvimento dos educandos (e da comunidade) em atividades de plantio e manutenção de árvores na cidade e no campo;

\section{JUSTIFCATIVAS}

O grupo avalia que há uma série de aspectos que justificam a necessidade e a validade de um projeto como este, destacam-se:

$\checkmark$ Grande desconhecimento em relação à fauna e flora regional.

$\diamond$ Distanciamento das pessoas em relação à natureza (não transformada).

$\checkmark$ Desvalorização e desconsideração quanto à praticas de conservação ambiental, implicando no uso dos recursos naturais como se fossem infinitos.

$\checkmark$ Poucos nativos reconhecem a importância ambiental da região e seus recursos.

$\checkmark$ A Escola é um excelente espaço para a educação ambiental, sendo o meio ambiente um dos temas transversais propostos nos P.C.N.s.

$\diamond$ Especificamente nesta U.E. há um grupo de educadores que já trabalham alguns aspectos ambientais da região.

Existe entre os integrantes do grupo uma vontade de desenvolver ações de educação ambiental com os estudantes e com a comunidade. 


\section{METODOLOGIA E PROCEDIMENTOS}

- Os professores trabalharão os "conteúdos" de maneira interdisciplinar.

- Os alunos desenvolverão ações práticas junto à comunidade, através de pesquisas e trabalhos individuais e em grupos;

- Serão promovidas oficinas de produção de mudas e de "manutenção" de árvores;

- Promover atividades para a sensibilização tais como: dinâmicas de grupo, apresentação de vídeos, leituras de textos, etc;

- Realizar visitas monitoradas e, na medida do possivel, desenvolver um programa de acompanhamento em viveiros de produção de mudas;

- Desenvolver pesquisas de campo em regiões preservadas através de excursões monitoradas;

- Elaborar um catalogo para identificação de algumas espécies nativas possiveis de serem plantadas. $O$ catálogo deve incluir caracteristicas como: floração, tipo de raiz, alimento para pássaros ou outros animais, altura média, comportamento das folhas, etc.;

- Promover uma campanha de plantio e preservação de árvores nas zonas urbanas e rurais;

- Buscar parcerias com setores da Prefeitura Municipal de lbiúna (meio ambiente, educação, agricultura, etc.) visando: fornecimento de mudas das espécies a serem plantadas, promoção de transporte para trabalhos de campo, viabilização da construção de um pequeno viveiro de mudas; aquisição de materiais de consulta para a biblioteca municipal, e principalmente apoio à campanha de plantio;

- Buscar o máximo envolvimento possivel dos segmentos escolares (direção, funcionários, professores e alunos) e da comunidade que se relaciona com a escola (parentes, vizinhos e outros interessados);

\section{MATERIAIS E RECURSOS}

Pequeno viveiro e recursos para seu funcionamento;

Mudas de espécies nativas;

Protetores de mudas;

Transporte para trabalhos de campo;

Material de impressão;

Palestrantes;

Monitores;

Especialistas em educação ambiental e em produção florestal para apoiar o detalhamento e acompanhar o desenvolvimento do projeto;

Coordenadores de atividades;

Professores;

\section{CRONOGRAMA}

As atividades ocorrerão a partir do $2^{\text {a }}$ semestre de 1999 (programação a detalhar) 


\section{APENDICE 29 - ESTIMULANDO A REFLEXÃO SOBRE O ANDAMENTO DOS PROJETOS}

\section{AOS PARTICIPANTES E COLABORADORES NO PROJETO "VALORIZANDO AS ÁRVORES NO NOSSO MUNICÍPIO"}

Partindo do compromisso com uma educação que valorize os educadores e educandos estive refletindo sobre o projeto e o curso e gostaria de compartilhar com os colegas minhas inquietações destacando três aspectos: i) continuidade; ii)- a efetiva participação e envolvimento dos alunos; iii)- os instrumentos e parâmetros de avaliação.

Apesar do desenvolvimento com sucesso de diversas atividades (lançamento oficial, plantio na escola,


co-participação na EXPO-GEO) o projeto não está trabalhando todos elementos propostos inicialmente. Seria interessante relermos o projeto e fazermos uma avaliação.

Entendo que todo processo educativo pretende mudar, transformar ou acrescentar algo nos/aos educandos ( $\theta$ nos/aos educadores), para que possamos chegar ao final e comprovarmos ou pelo menos termos recursos para argumentarmos sobre a empreitada é interessante conhecermos e registrarmos a "situação" ou a "condição" ou as "características iniciais" dos envolvidos. Isto não foi feito no início do projeto, mas podemos agora fazer um levantamento que como os alunos e nós "estávamos" no inicio do projeto ou então aguardarmos o encerramento dos trabalhos e procurarmos identificar as mudanças, transformações ou acréscimos oferecidos pelo processo.

Considerando o amplo leque de objetivos do nosso projeto, creio que uma questão importante para efeito de avaliação é: quais os elementos, instrumentos e parâmetros que podemos usar para indicar a situação do projeto em relação aos seus objetivos? (Levantei esta questão naquela oficina sobre os projetos realizada após o encontro com 0 Femando Bignardi, porém creio que deveria ter insistido na questão em oportunidades posteriores)

É possivel, neste momento, criarmos instrumentos de avaliação para o projeto? Que tipo: Questionários, entrevistas, reuniões, dinâmicas de grupo, relatórios, outros? Quando deveriam ser aplicados estes avaliadores: agora ? , no final dos trabalhos? em ambos os momentos?

O que cada professor possui, que possa servir como elemento/instrumento de avaliação ? Por exemplo: anotações pessoais (do professor ou de alunos); registros, transcrições ou avaliações de atividades, fatos ou depoimentos; textos; desenhos; fotografias; trabalhos de pesquisa, "produções" de alunos; etc.

Como está sendo a amarração entre as atividades realizadas e os objetivos gerais.

Até que ponto os objetivos gerais estão sendo o referencial para definição de nossas posturas, estratégias, atividades, conteúdos ... ?

Quanto avançamos no sentido dos objetivos específicos?

Num sentido mais pragmático precisamos refletir sobre:

Como ampliar efetivamente o envolvimento dos educandos (e da comunidade) no projeto de forma a caminhar no sentido dos objetivos gerais do projeto?

O grupo tem fôlego e interesse em novas iniciativas? Diversas atividades previstas no projeto inicial ou dele desdobradas poderiam ser promovidas, inclusive como forma e conseqüência de um maior envolvimento dos alunos destacando-se:

- desenvolver sementeiras de árvores em caixotes (eventualmente associado a alguma pesquisa);

- completar e aperfeiçoar o Mapa da Situação da Arborização da Cidade, por exemplo: checar as ruas, levantar as praças e outras áreas verdes localizadas na cidade, levantar as árvores de porte significativo dos quintais, preparar o mapa de áreas carentes de (ou prioritárias para) arborização,

- formulação de um mural sobre o projeto;

- promover um debate sobre o Parque Estadual do Jurupará

- idealizar, preparar, desenvolver e avaliar uma campanha educacional visando a valorização e ampliação da arborização urbana incluindo ou idealizar e realizar uma "Campanha de adoção de árvores";

- preparação de um folheto sobre a importância das ánores nas zonas urbanas e rurais;

- preparação de um catálogo de árvores possiveis de serem usadas na arborização urbana da cidade

- formulação, aplicação e tabulação de questionários, entrevistas ou outra forma de consulta à população sobre árvores, arborização urbana, meio ambiente, etc.

- expor em locais de grande acesso os mapas sobre arborização,

- promover juntamente com outros parceiros uma iniciativa de plantio de arvores (incluindo: escolha das áreas e espécies, ações para o comprometimento da população, construção dos "gradis", registro das arvores plantadas acompanhamento da manutenção das árvores), 
Olá colegas educadores(as):

A experiência do curso e todos os seus desdobramentos foram muito ricas (para mim, para os cursistas, para palestrantes, para alguns alunos e para o Prof. Marcos) considerando isto, gostaria de resgatá-las e se possível relatá-las a outros professores e pesquisadores. Uma das formas possíveis seria através da produção de uma apostila que, se acharmos pertinente, poderá ser editada na forma de livro (o nosso livro).

Termos o nosso livro seria algo muito bom para nossa experiência profissional, para nosso currículo, e por que não assumir ?! para nossa satisfação pessoal. Produzir um livro não é algo tão difícil, mas exigirá alguma dedicação daqueles que assumirem a proposta.

O principal trabalho será a produção do texto. Detalhando esta atividade podemos pensar em algumas etapas: escolha do tema; definição da estrutura do texto (principais tópicos e idéias, forma de apresentação, divisões do texto, etc.); desenvolvimento do rascunho; produção da primeira versão; avaliação por parte dos parceiros; revisão: produção da segunda versão: leitura e avaliação por parte da equipe; $2^{a}$ revisão, correção ortográfica e gramatical, texto final.

Parece muita coisa, talvez até assuste, mas só saberemos se é possível se tentarmos. Considero que o grupo é capaz de enfrentar este desafio.

Partindo das recordações, anotações, releituras,

Desenvolver uma coleção de textos que poderiam ser assinados por uma pessoa, por uma dupla e até por um trio. Os textos poderiam apresentar nossos sentimentos, percepções, reflexões, avaliações e considerações sobre: o curso no geral / o conjunto de oficinas e palestras / uma oficina ou palestrante específico / uma atividade específica (atividades de campo, leituras, pesquisas, etc.) / o projeto (construção da proposta, desenvolvimento, atividades específicas, avaliações, reflexões, ...)

Algumas questões podem colaborar para a produção dos textos:

O que esta experiência provocou em mim?

Qual o valor de se desenvolver um projeto educacional na escola?

É possível adaptar experiências do curso para o ambiente escolar? Como?

Também podem servir como ponto de partida o meu texto "Refletindo sobre o projeto (distribuído em meados de novembro), o texto de avaliação enviado à Secretaria Estadual de Educação (cópia anexa) e os textos distribuídos durante o curso. 
APÊNDICE 31 - VERSÂO INICIAL DO MAPA DE ELEMENTOS SIGNIFICATIVOS PARA A PESQUISA

Esta é uma versão preliminar utilizada no transcorrer dos trabalhos conforme detalhado no item 3.5 da dissertação.

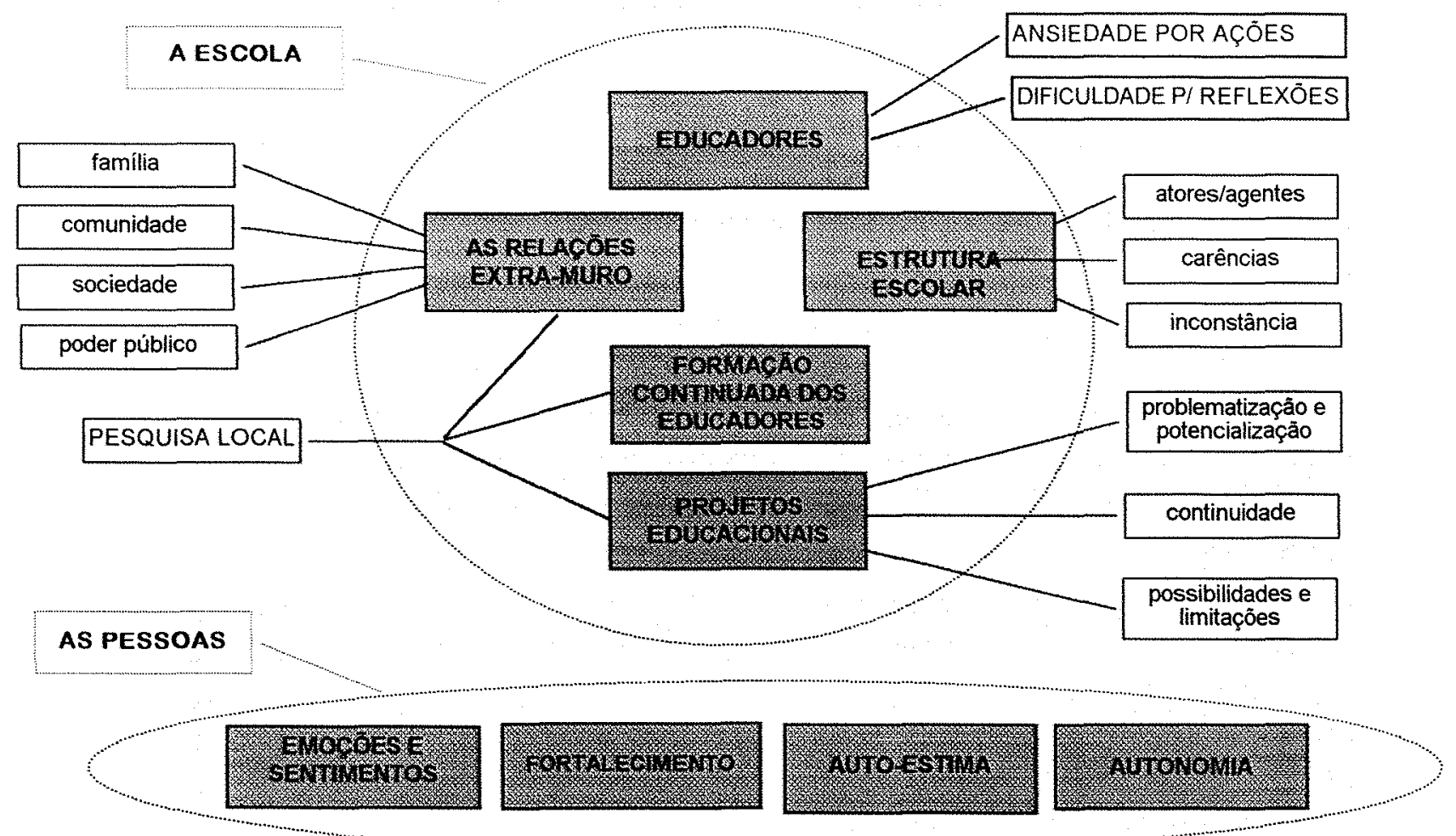

\section{O AMBIENTALISMO}
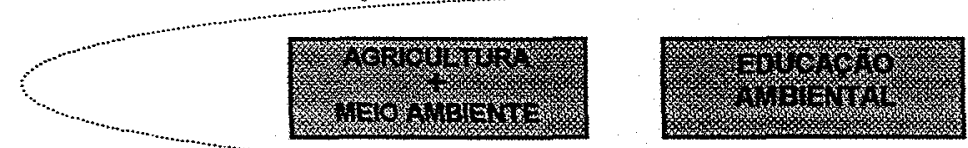

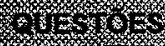

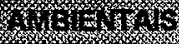

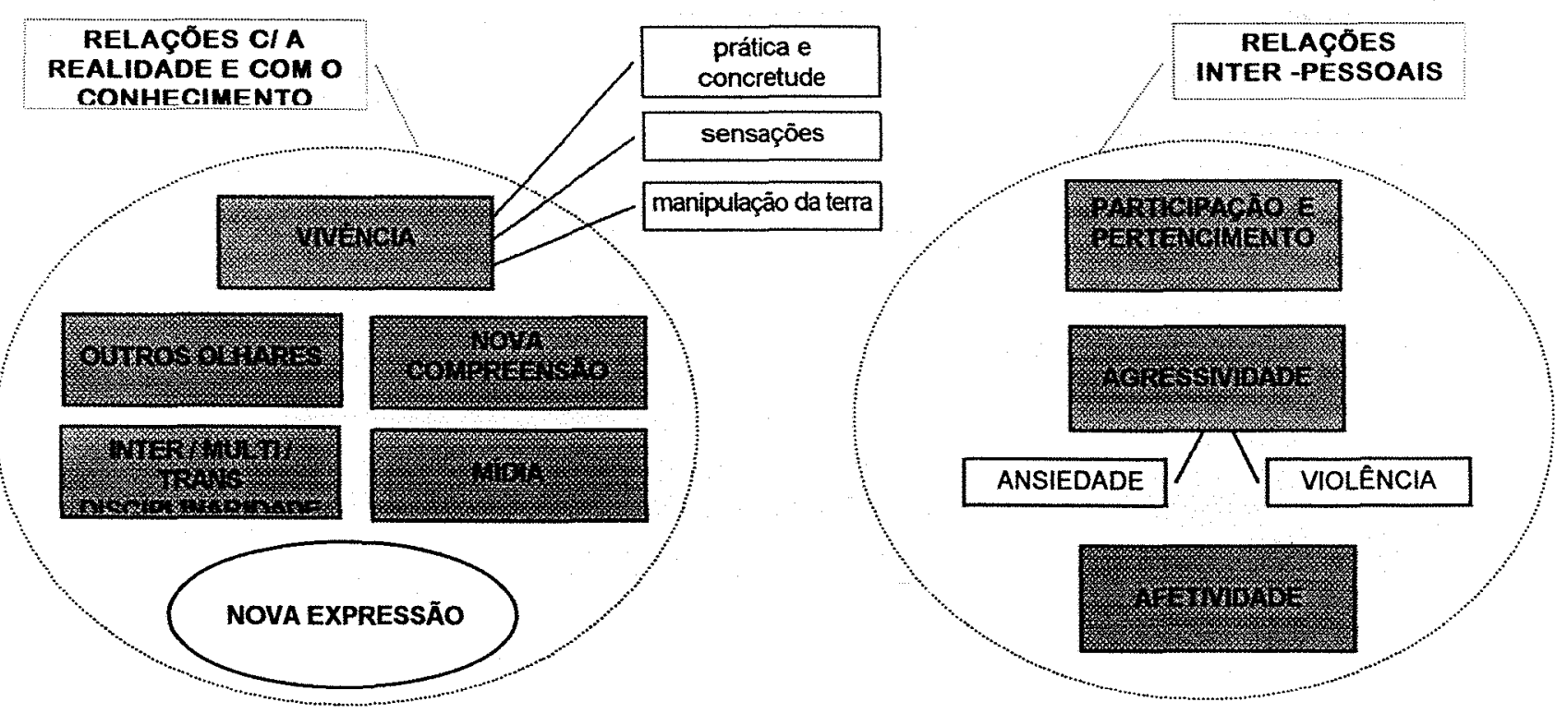


APENNDICE 32 - LEVANTAMENTO DE INICIATIVAS DE ENSINO AGRO-AMBIENTAL FL. 1 de 3

\section{LISTA DE TRABALHOS APRESENTADOS NO} $1^{\circ}$ EnCONTRO SOBRE EdUCAÇÃo AMBIENTAL NA AGRICULTURA

- EDUCAÇÃo AMBIENTAL E A QUESTÃo das MATAS NATIVAS E dAS MATAS CILIARES*

- REFORMA AGRÁRIA E MEIO AMBIENTE: MOVIMENTOS PARA UMA SOCIEDADE MAIS SAUDÁVEL.

- PAPEL DA EDUCAÇÃO AMBIENTAL NA PROMOÇÃO DE SISTEMAS AGROFLORESTAIS NO BAIXO RIO NEGRO, AMAZONAS*.

- PROJETO GAMA - GRUPO DE AÇ̃̃O PARA MELHORIA AMBIENTAL**

- PROGRAMA DE EDUCAÇÃO AMBIENTAL-RESGATE E PROPOSTA PARTICIPATIVA.

- AGRICULtura ECOLÓGICA, MUdANÇA dE VALORES E EDUCAÇÃo.

- PROGRAMA DE CAPACTTAÇÃo DA COMISSÃo TÉCNICA DE AGRICULTURA ECOLÓGICA/SAA.

- INTRODUÇÃO DA ABORDAGEM DE SISTEMAS AGRÁRIOS NA REGIX̃o ADMINISTRATIVA DE ASSIS, SÃO PAULO .

- JOGO DO RIO.

- MeU CARO liXo.

- "3D SLIDE SHOW".

- EDUCAÇÃo AGROAMBIENTAL E A CAPACITAÇÃO DE PROFESSORES.

- RESÍDUOS SÓLIDOS DOMÉSTICOS: UM PROBLEMA SOMENTE URBANO?

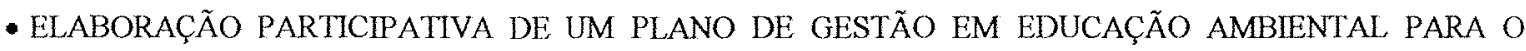
CAMPUS "LUIZ DE QUEIROZ",

- PROPOSTA METODOlÓgICA DE DIAGNÓSTICO DE SISTEMAS DE PRODUÇÃo PARA FINS DE SUSTENTABILIDADE.

- MATAS CILIARES DE ITATINGA.

- A ESCOLA VAI À FLORESTA : TRILHAS ECOLÓGICAS PARA EDUCAÇÃo AMBIENTAL

- PROJETO GERMINAR: ARBORIZAÇÃO URBANA PARTICIPATTVA E INTERDISCIPLINARIEDADE VIVENCIADA. 


\section{APENDICE 32 - LEVANTAMENTO DE INICIATIVAS DE ENSINO AGRO-AMBIENTAL FL. 2 de 3}

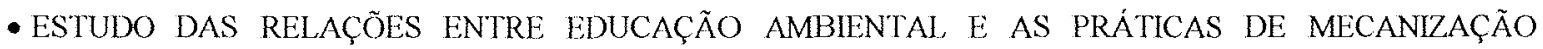
AGRÍCOLA.

- programa maRgem VERde/CATI-SAA: restauraÇÃo de matas ciliares e educaÇÃo AMBIENTAL. PN21

- FOMENTO FlORESTAL COM ESPÉCIES NATIVAS PRATICADO PELO VIVIIIRO DA CESP DE PORTO PRIMAVERA JUNTO A PRODUTORES RURAIS DA REGIÃO DE ASSIS -

- Na Trilha da Árvore. Escolástica Ramos de Freilas.

- Um Programa de Educação Ambiental e Ecoturismo para a Estação Experimental de Agrononia de Ubatuba.

- VÍDEO AMBIENTAL: REFLEXÕES E PERSPECTIVAS*.

- Implantação de Farmácia Viva numa Escola de Ensino Fundamental em Campinas,

- Estudos sobre um programa de reflorestamento ciliar: subsídios para a compreensão das relações entre extensão rural e educação ambiental ${ }^{*}$.

- A EDUCAÇão ambIENTAL USANDO OS PROJETOS DE PESQUTSA CONDUZIDOS NA ESTAÇÃo EXPERIMENTAL DE AGRONOMIA DE PINDORAMA.

- REPLANTANDO A PAISAGEM: EDUCAÇÃo AMBIENTAL E RECOMPOSIÇÃo DE MATA CILIAR EM ITATINGA, SP.

- PLANEJAMENTO DO USO SUSTENTÁVEL DA TERRA NA ESTAÇÃO EXPERIMENTAL DE JUNDIAÍ.

- JOVENS E ÁRVORES, URBANOS.

- PROJETO JOVEM VIVEIRISTA*.

- INTRODUÇÃO DE Achatina fulica (MOLLUSCA, ACHATINIDAE) NO BRASIL: RESPONSABILDADE PROFISSIONAL E INFORMAÇÃO TÉCNICA.

- PLANTAS INVASORAS EM SISTEMAS NATURAIS E AGRÍCOLAS NO BRASIL: O PAPEL DA PESQUISA E DA EDUCAÇÃO AMBIENTAL.

- ELEMENTOS PARA O PLANEJAMENTO DA EDUCAÇÃo AMBIENTAL EM PROPRIEDADES AGRÍCOLAS.

- OFICINA DE CONSERVAÇÃo AMBIENTAL.

- CIRCUTTO ECOLÓGICO: UMA FERRAMENTA DE EDUCAÇÃo AMBIENTAL.

- EDUCAÇÃo AMBIENTAL E AGROTÓXICOS.

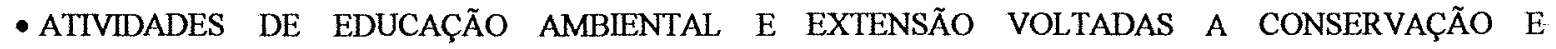
RECUPERAÇÃO DAS MATAS DE GALERIA DO BIOMA CERRADO*. 
APÊNDICE 32 - LEVANTAMENTO DE INICIATIVAS DE ENSINO AGRO-AMBIENTAL FL. 3 de 3

- EDUCAÇÃo AMBIENTAL PARA IMPLANTAÇÃo dE FloRESTAS.

- ANÁlISE ESPAÇO-TEMPORAL DA PRODUÇÃO AGROPECUÁRIA NA REGIÃo DE RIBEIRÃo PRETO, SP, ATRAVÉS DE TÉCNICAS DE GEOPROCESSAMENTO*.

- MUTtRÃo agroflorestal.

- A SENSIBLLZAÇÃo E O ENVOLVIMENTO EM TRABALHOS COM AGROECOSSISTEMAS BIODIVERSOS ORIENTADOS PELA SUCESSÃO NATURAL.

- PROJETO DE EDUCAÇÃo AGROAMBIENTAL PARA AGRICULTORES ENVOLVIDOS COM A REFORMA AGRÁRIA EM PASTOS BONS,

- PRÁTICAS INTEGRADAS DIRECIONADAS À EDUCAÇÃo AMBIENTAL.

- PROGRAMA MUNICIPAL DE CONSERVAÇÃo DO SOLO E DA ÁGUA NO MEIO RURAL, JUNDIAÍ, SP.

- A PESQUTSA básica E O ENSINO PÚBlico: uma EXPERIÊNCIA DE MElHORIA do ENSINO DE BOTÂNICA*.

- AGRICULTURA SUSTENTÁ VEL: ESTUDO PROSPECTIVO DE UMA MICROBACIA HIDROGRÁFICA*.

- EDUCAÇÃO AMBIENTAL E JOVENS ASSENTADOS:

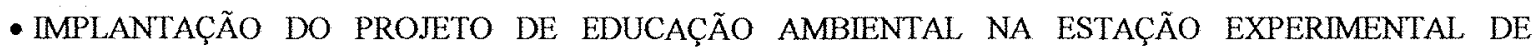
AGRONOMIA DE PINDORAMA*.

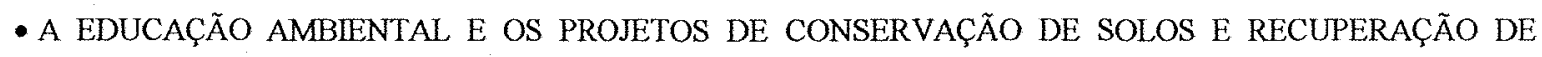
NASCENTES NA ESTAÇÃO EXPERIMENTAL DE AGRONOMIA DE PINDORAMA.

- PROJETO DE EDUCAÇÃO AMBIENTAL PONTAL VERDE. 


\section{APENNDICE 33 - CÓPIAS DO CADERNO DE CAMPO DA PESQUISA FL. 1 de 2}

Um dos instrumentos usados para registro de informações, observações e impressões durante a pesquisa foi o caderno de campo. As anotações eram feitas tanto durante os encontros ou reuniôes como em momentos posteriores.

\section{TAQZ1Ob199 REUUËS C PROFESSORES}

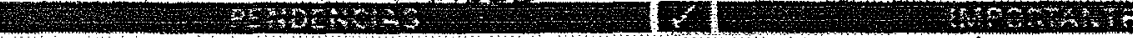

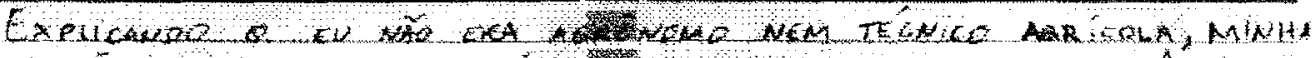

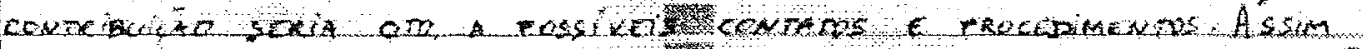

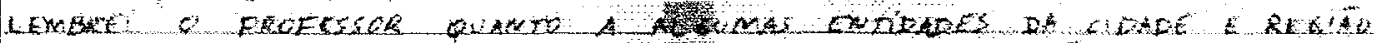

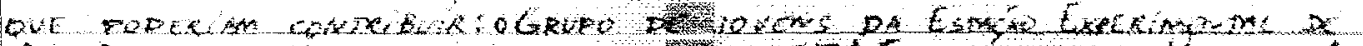

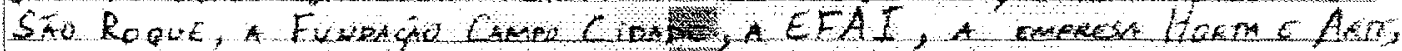

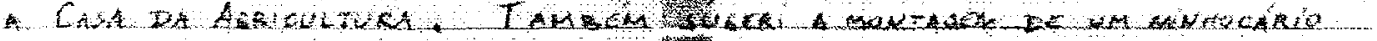

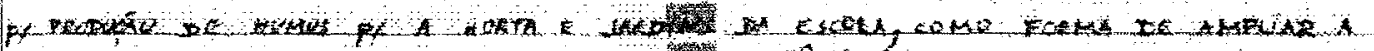

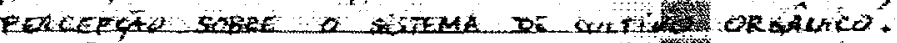

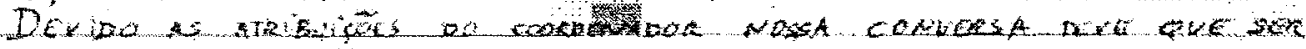

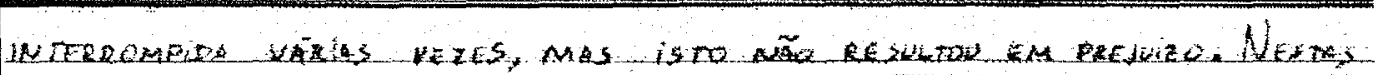

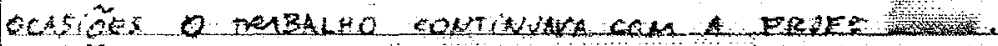

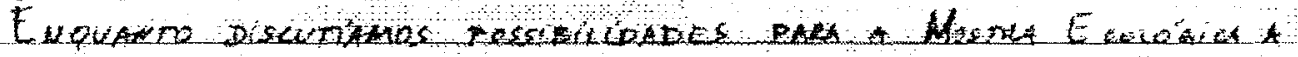

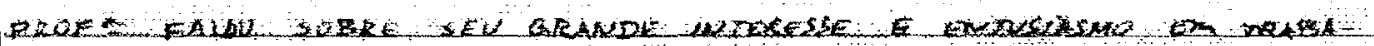

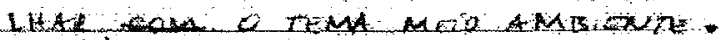

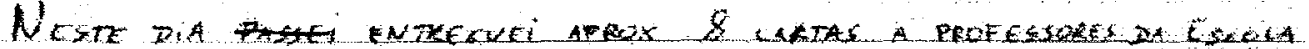

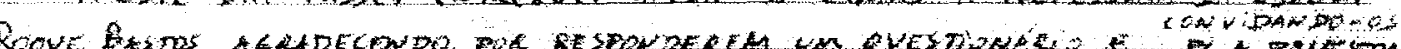

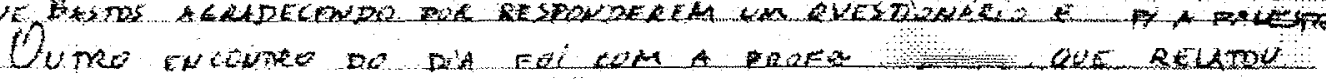

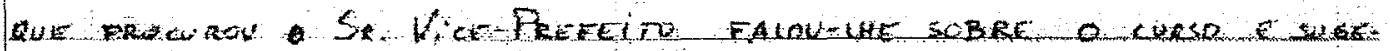

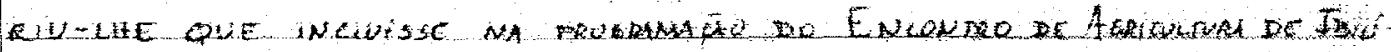



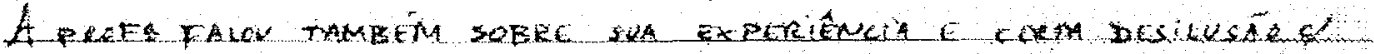

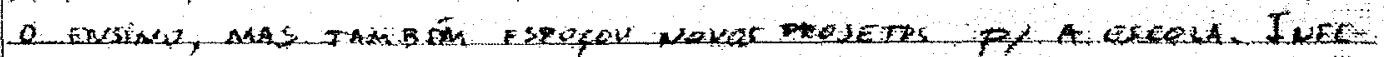

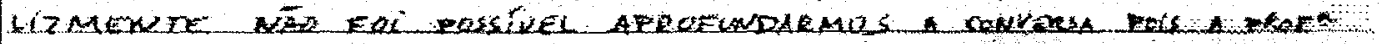

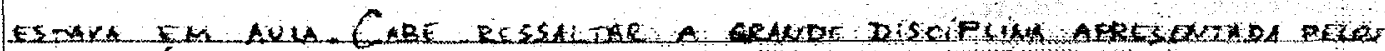

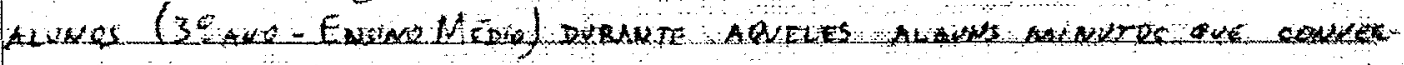
SAT NO JUET DA SULA DE AULA.

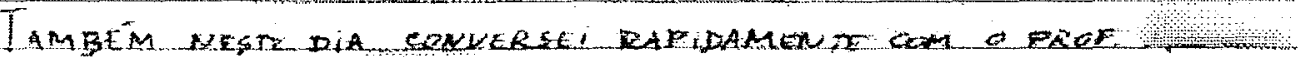

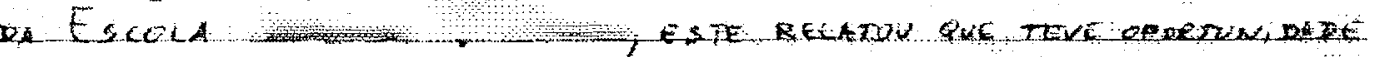

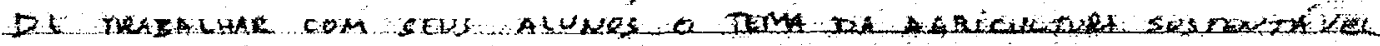

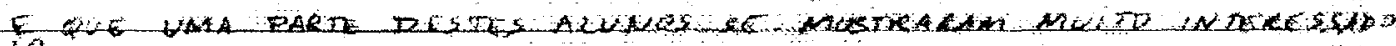

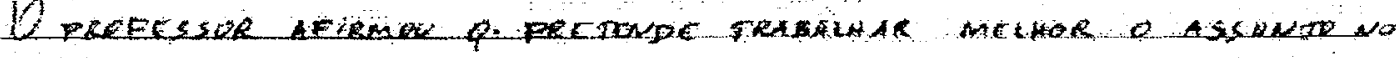
ANO VER.

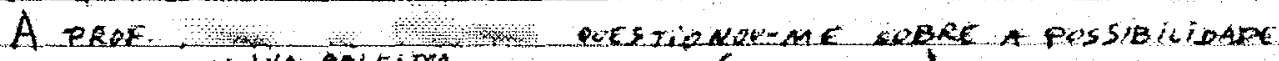

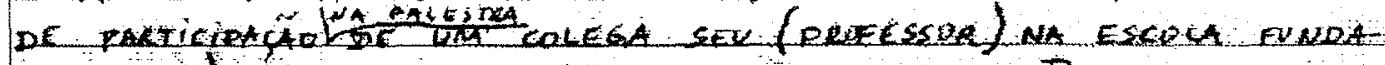

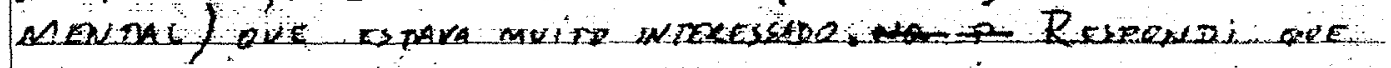

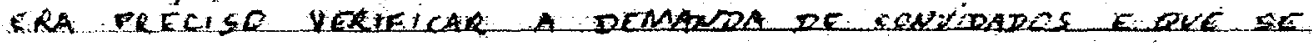

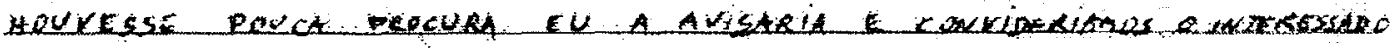


APENNDICE 33 - CÓPIAS DO CADERNO DE CAMPO DA PESQUISA FL. 2 de 2

IMPRESSOES - CONIDOXYGOES

RELATIVAS A

DATA 21104199

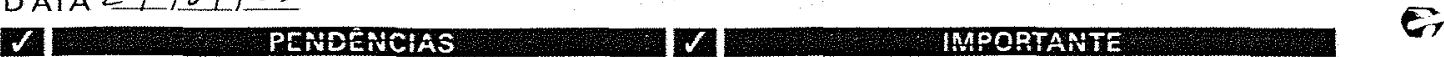

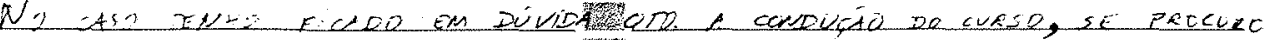

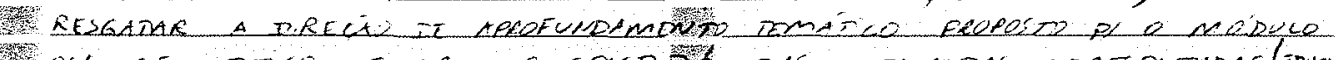

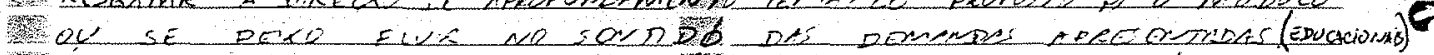

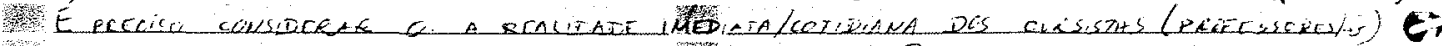

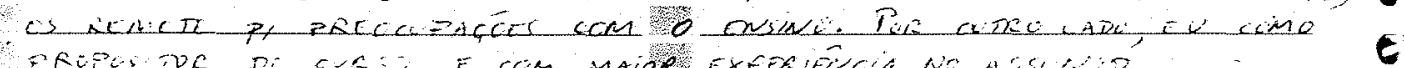

W

WAT Sil Dom

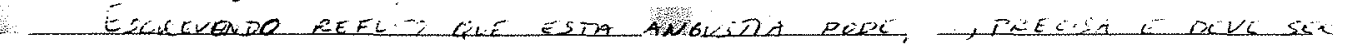
जिए?

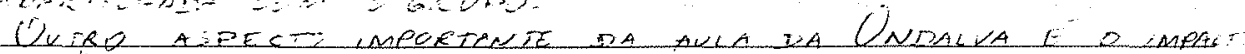

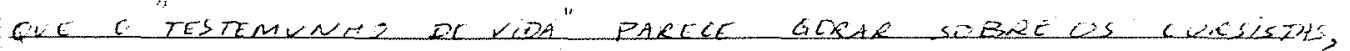

6

0

c.

DO PRODUTCR GECALDO

(3)

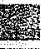

A proposta de uMa nOVA perspectiva de munde, incivindo

- IMA validacáo científica e agregando o emecional, o eisioló́gilo

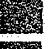

20. PIRITAL, E OUDRAS DIMENSOES RARECE TER PROVVCADD UM GRANDE IMPACTO NOS CURSISTAS, A BALANDO SUAS CONVICGÕES:

No encontro de 3 dias antes (ovando fizomos visidas aos

2 produtores) o produtor Goraldo havia tambón aprestendado



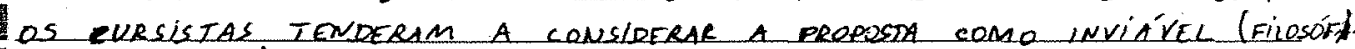
CA-SONHADURA) NÁO PRATIĆ́VEL OU PEL MENOS NÃO REPRODUZÍVEL OM GRANDE ESCALA (ObS: ESTAS IMPRESÉES FOSAM COLETADAS PRINCIRALMONTE CH COM 4 cURSISTA DURANTE AS VIAGONS DE CARRO ONTRE AS PRPPEIODADES)

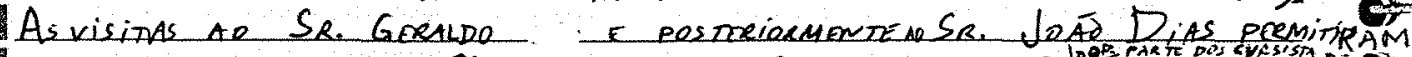

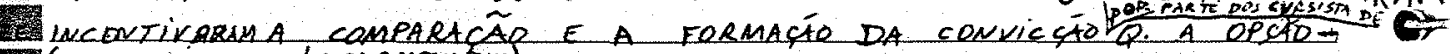

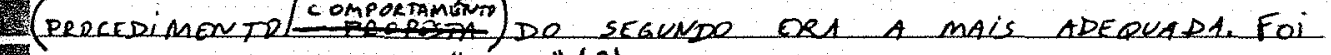
- Esta convicsão que para "alguns" (?) ficou abalada.

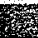

Muito significativa FOI a aVALIAGAO NO FINAL DO DIA

APONTANDO PARA A - QUESTÁO DE RELACIONAR NDO QUE HAVIAMGS

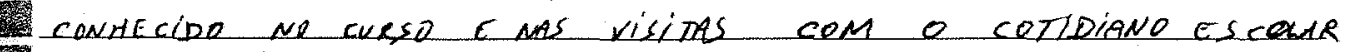

No SENTIDO DE IR ALEÁM DO REPASSE DE WFORMACẼS.

3.

Ainda sojre o "contrino" ta calestra, creio Q, em funḉó do tompo restrito e das demandas (QUESTDÉs) ous ivrGiram no transcorrex, A

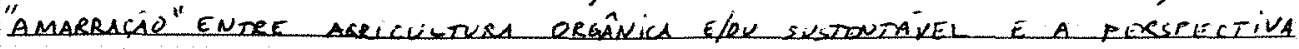

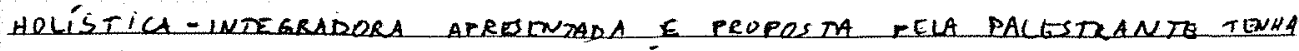



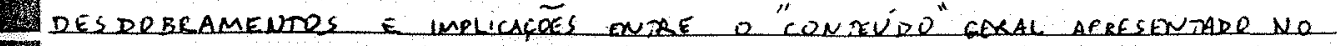
DiA E A AGRIC SUSTENIAVEL. 等 
APÊNDICE 34 - QUESTÕES COLABORADORAS NA FORMULACÃO DE PROJETOS EM EDUCACÃO AMBIENTAL.

1) Qual o entendimento do(s) propositor(es) sobre: meio ambiente e sobre questões ambientais?

2) Qual o entendimento do(s) propositor(es) sobre educação e sobre projetos educacionais?

3) Qual o entendimento do(s) propositor(es) sobre educação ambiental?

4) Qual o contexto sócio-ambiental (situação) em que se pretende intervir com o projeto?

5) Que aspecto, questão ou problema se pretende tratar ou enfrentar?

6) Quais elementos educacionais serão trabalhados: informações e conceitos; comportamentos e atitudes; valores; competências e habilidades; etc.?

7) $\mathrm{O}$ que se pretende com a proposta? (Ou) Quais as intenções mais profundas que animam a proposta? Não confundir objetivos com metas (quantificação dos objetivos) ou com procedimentos (açöes, formas e instrumentos para alcançar os objetivos)

8) Quais os objetivos educacionais da proposta? Obs.: não confundir com metas ou procedimentos.

9) Quais os materiais bibliográficos de apoio à formulação da proposta e a sua implementação?

10) Por que elou qual a importância de desenvolver tal proposta?

11) Por que os propositores devem desenvolver tal proposta? (Ou) O que possibilita aos propositores implementarem a proposta?

12) Quem está propondo a iniciativa? Qual a participação dos atingidos pelo projeto em sua formulação?

13) Quem serão os executores da proposta? (No caso de não ser os propositores)

14) Quem serão os educandos no projeto?

15) Quais as responsabilidades e atribuições dos envolvidos?

16) Como será promovida a proposta?

17) Quais as fases ou etapas do projeto? (OU) Em que ordem as coisas serão feitas?

18) Quais as metas do projeto? (OU) Quais as prioridades? (OU) Em que ordem se pretende atingir os objetivos? (OU) Que "produtos" ou resultados práticos se pretende atingir em cada fase e ao final da iniciativa?

19) Quando e em quanto tempo será encaminhada a proposta e suas etapas?

20) Quais as necessidades da proposta quanto a: materiais, recursos, pessoas?

21) Quais os recursos didáticos serão utilizados ? (livros, textos, fitas, jogos, etc.)

22) Quem ou qual instituição finaciará/fornecerá as pessoas e os materiais, instalaçães, etc. ... necessários?

23) Quais as dificuldades que os propositores esperam que o projeto enfrente?

24) Como será o acompanhamento e o registro do projeto? Quem é responsável por isso?

25) Como os propositores saberão se estão indo bem?

26) O que será avaliado no projeto como um todo e em suas fases? Quando? Por quem? Para que? Como? Com que instrumentos? Por quais parâmetros? Haverá avaliações intermediárias?

27) O projeto se articula-se com outras iniciativas educacionais ou ambientais? Como?

28) A proposta contempla os sonhos e as intençöes dos propositores?

29) A proposta contempla necessidades ou anseios dos educandos?

30) Quais as articulaçöes entre a proposta e os projetos individuais de cada envolvido ? Quais as articulaçöes entre a proposta e os projetos da comunidade e sociedade em que ele é promovido?

31) Há intenção de que a iniciativa continue? Como?

32) Interessa que outras pessoas ou entidades fiquem sabendo da iniciativa? Caso afirmativo como será feito isto?

Numa perspectiva mais didática e formal as respostas podem ser assim agrupadas:

a) INTRODUÇÃO: 1, 2, 3, 4, 5, 6, 27

b) OBJETIVOS: 7,8

c) METAS: 17

d) JUSTIFICATIVAS: 10, 11

e) MÉTODOS E PROCEDIMENTOS: 12, 13, 14, 15, 16, 31, 32

f) ETAPAS/PROGRAMAÇÃO: 18, 19

g) MATERIAIS; 20, 21, 22

h) AVALIACÃO: $23,24,25,26$

i) REFERÉNCIAS BIBUOGRÁFICAS: 9,21

j) QUESTÕES AUXILIADORAS PARA FORMULAR E AVAUAR A PROPOSTA: 28, 29, 30 


\section{APÊNDICE 35 - ROTEIRO PARA AS ENTREVISTAS COM OS PARTICIPANTES}

No geral, qual a sua avaliação do curso ? (O que vc achou?)

para o conjunto dos participantes? (Pontos positivos, pontos negativos, carências, dificuldades, etc.)

especificamente para você? (Pontos positivos, pontos negativos, carências, dificuldades, etc.)

Especificamente sobre educação ambiental

Especificamente sobre agricultura e meio ambiente?

Você mudou alguma coisa que se relacione às questões entre agricultura e meio ambiente?

- Comportamentos pessoais?

- No ensino?

- Quais as principais dificuldades para estas mudanças?

Você poderia fazer uma avaliação geral sobre o projeto desenvolvido por sua equipe quanto:

- ao tema central (por que fol escolhido ?)

- ao planejamento e redação da proposta

- ao encaminhamento

- aos resultados

- aos desdobramentos

- à participação dos estudantes.

- à participação dos colegas

- a sua participação

Segundo seus conhecimentos, como as questões envolvendo as relações entre agricultura e meio ambiente são tratadas no ensino médio atualmente nas escolas da região?

Qual o grau de conhecimento dos educadores da região sobre este assunto?

Qual o grau de conhecimento dos alunos sobre este assunto?

O assunto desperta interesses e motivações: - nos educadores? nos alunos?

É possivel estimular os educadores para que eles contribuam para a expansão da agricultura sustentável? Como? (Eventualmente: porque?)

É possivel estimular os alunos para que eles contribuam para a expansão da agricultura sustentável? Como? (Eventualmente: porque?)

Como ampliar e melhorar a abordagem sobre as "relações entre agric. e meio ambiente", no ensino médio?

- Existem conteúdos ou sub-temas sobre este assunto que são mais apropriados, atraentes ou impactantes para serem trabalhados no ensino médio? Quais seriam?- Quais recursos didáticos podem ser utilizados para tratar este assunto

- Quais as posturas e práticas didático-pedagógicas que podem contribuir para um verdadeiro processo educativo envolvendo o assunto?

0 que você entende como um verdadeiro processo educativo?

O que você acha sobre a promoção de visitas às estabelecimentos orgânicos como procedimento educacional?

0 que você acha da promoção de projetos educacionais para tratar o assunto?

Quais as dificuldades e empecilhos para abordagem do assunto?

A ampliação de contatos com o assunto pode gerar alguma influência mais duradoura

- nos professores? Quais?

- nos alunos? Quais?

- em suas comunidades? Quais ?

Quanto você acha que o ensino deste assunto pode contribuir para:

incentivar posturas mais participativas diante do assunto?

aumentar o questionamento do atual modelo agricola?

influir na conscientização sobre as possibilidades de adoção de modelos agricolas alternativos? 
APÊNDICE 36 - REGISTROS FOTOGRÁFICOS DE ALGUNS ENCONTROS-OFICINA.

A direita - Oficina sobre viveiro de plantas e jardinagem. Participantes manipulando solos de diferentes cores, texturas, cheiros, etc. Outros observando amostras de sementes.

Abaixo - Oficina sobre Educação Ambiental A dimensão afetiva foi valorizada e mobilizada em vários momentos.
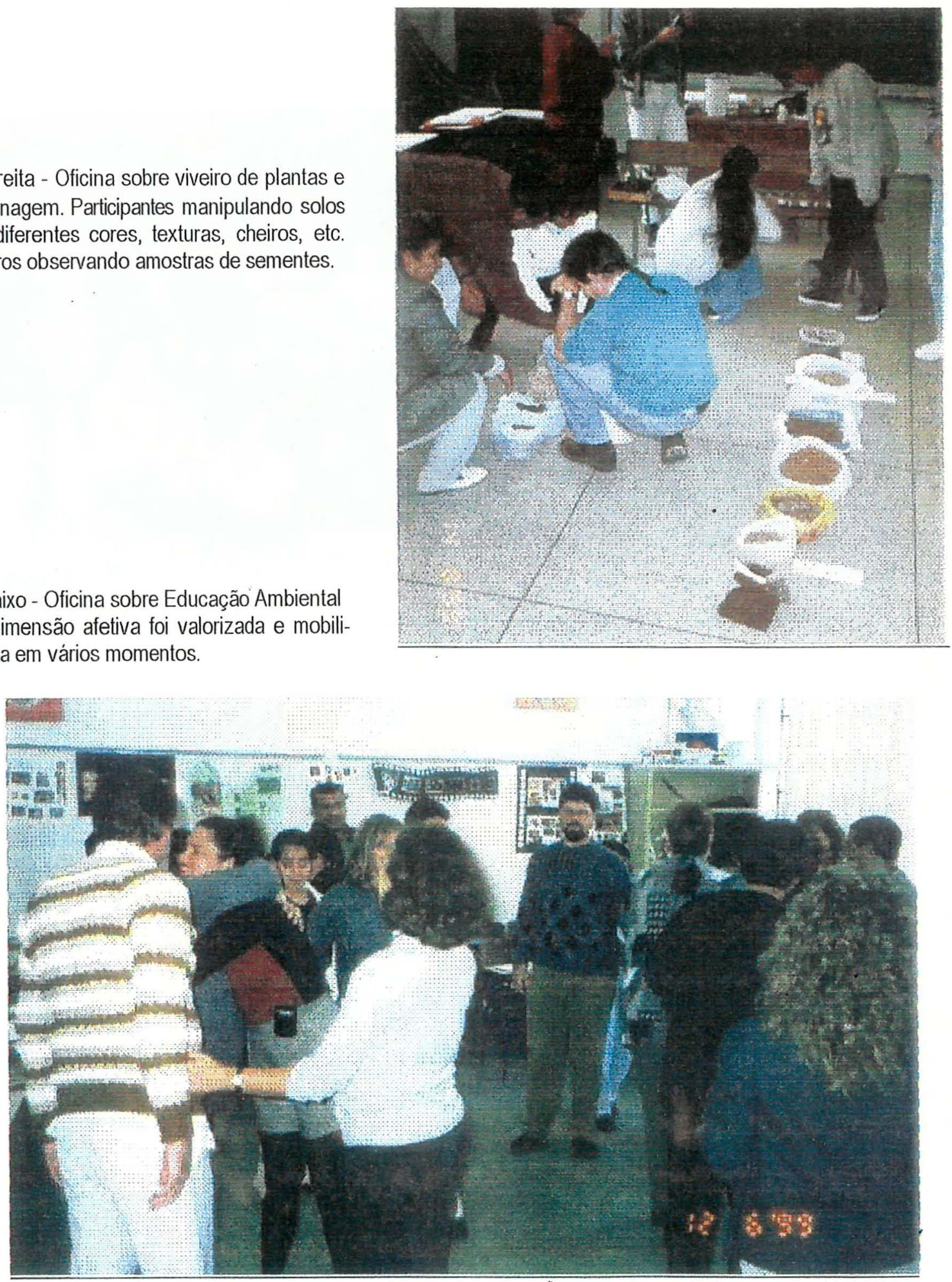
APÊNDICE 37 - REGISTRO FOTOGRÁFICO DA MAIORIA DOS PRINCIPAIS ENVOLVIDOS NA PESQUISA

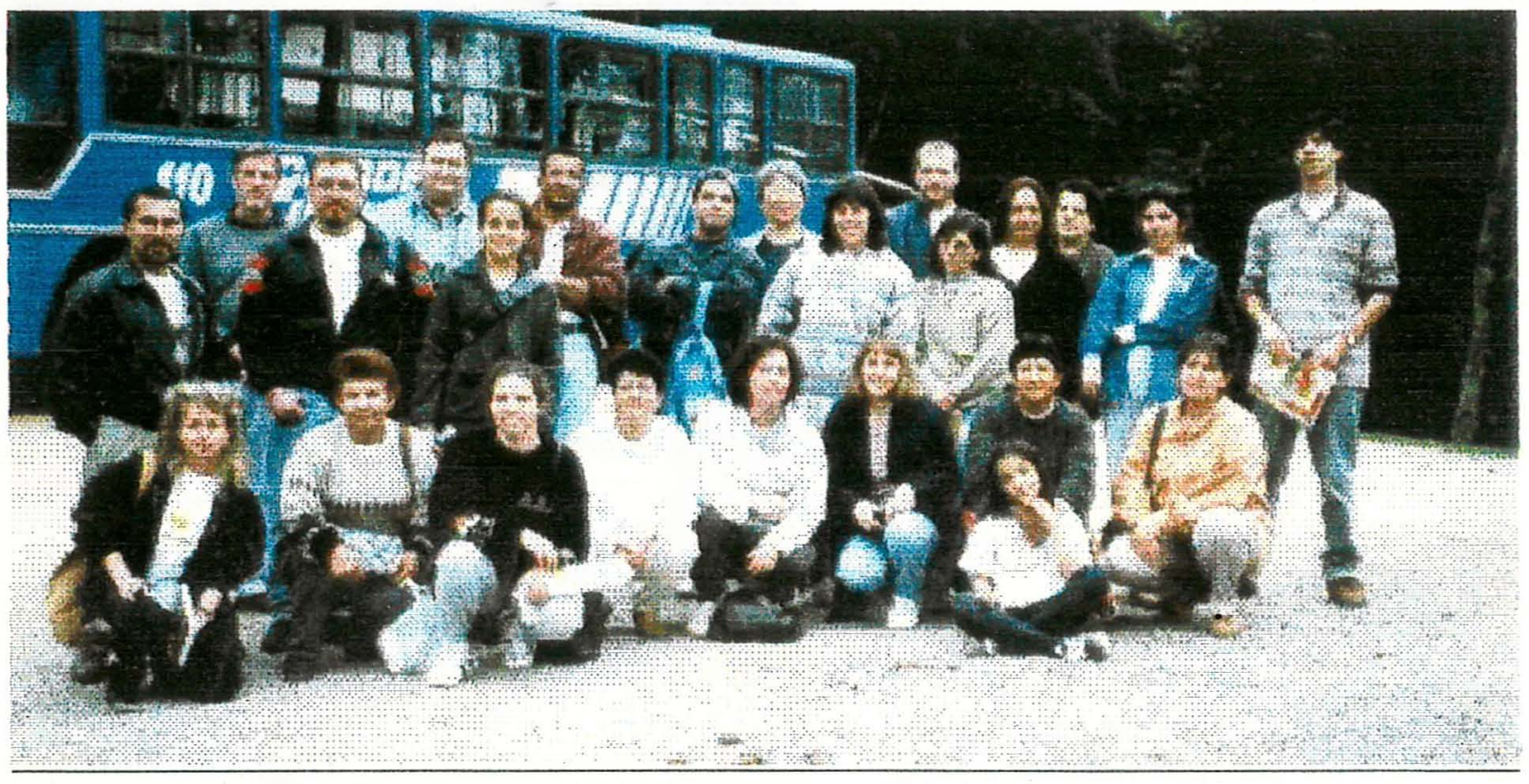

